UNIVERSIDAD NACIONAL DE LA PLATA

FACULTAD DE BELLAS ARTES

Secretaría de Posgrado

\title{
LO SINIESTRO EN LA OBRA DEL DISEÑADOR INGLÉS ALEXANDER MCQUEEN
}

\section{ELIZABETH RIVERA GÓMEZ}

Tesis para optar por el grado de Magíster en Estética y Teoría de las Artes

Directora Dra. Analía Melamed, Universidad Nacional de La Plata Codirectora Dra. María Alejandra Vitale, Instituto de Lingüística, FFyL Universidad de Buenos Aires

La Plata, 7 de Mayo de 2014 


\section{ÍNDICE GENERAL}

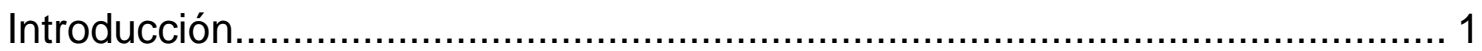

I. La moda y el arte. Diseñadores artistas y artistas diseñadores ................... 16

Origen de los estudios de moda e investigaciones actuales ....................... 21

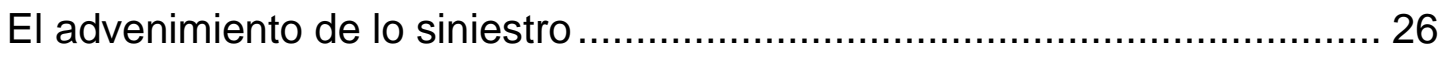

II. Lo siniestro

La conceptualización de lo siniestro ............................................................. 33

Lo siniestro y otras categorías estéticas.................................................... 38

III. Alexander McQueen, heraldo de lo siniestro.......................................... 46

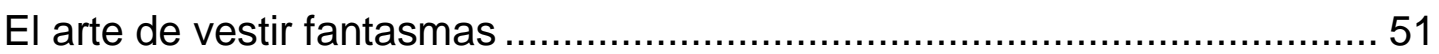

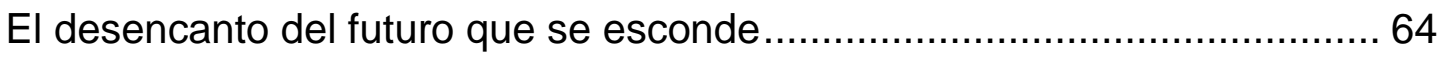

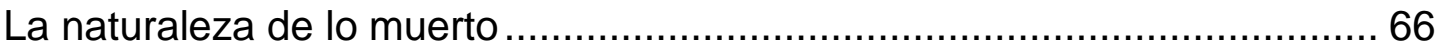

La exquisita monstruosidad de lo doble .................................................... 71

Cadáveres femeninos: las muñecas de McQueen ...................................... 79

Accesorios de la fragmentación............................................................ 97

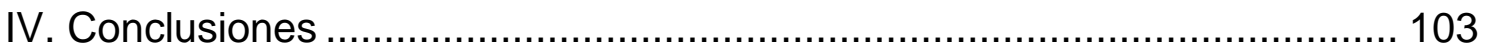

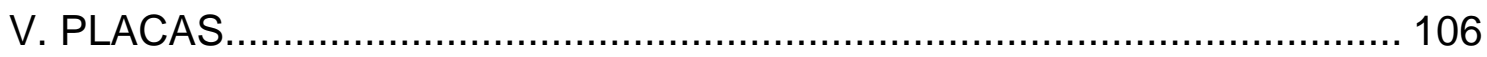

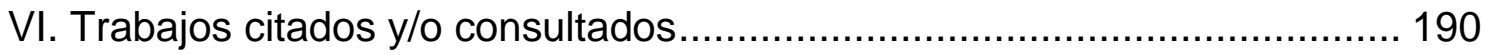




\section{Introducción}

Los marcos teóricos actuales dedicados al estudio de la moda se concentran en recorridos históricos sobre el diseño de las prendas. ${ }^{1} \mathrm{Si}$ bien se puede pensar que es prácticamente imposible despegarse por completo de tal forma de estudio, no es mi intención continuar con ese acercamiento en el siguiente trabajo. Muchos autores han realizado excelentes investigaciones dirigidas a ubicar a la moda dentro de la historia. Mi propósito es desarrollar una deliberación teórica sobre la producción de Alexander McQueen, uno de los diseñadores más emblemáticos de finales de los años noventa y comienzos del presente siglo, sobre la base del concepto de lo siniestro, término que proviene del psicoanálisis freudiano. De modo de sumar a lo ya escrito sobre el tema, una nueva posibilidad de pensar la moda. No pretendo duplicar el trabajo que proponen los reportajes de moda cuya finalidad, si bien es parte fundamental del mundo del diseño de prendas, se puede encontrar en revistas especializadas, periódicos y recientemente en cientos de sitios de internet dedicados al tema. Una tesis es el sitio más adecuado para realizar análisis teóricos y críticos sobre la moda y sus contextos.

En el intento de ir más allá de la mera descripción de las prendas decidí reubicarlas bajo una nueva mirada capaz de releerlas y obtener nuevas configuraciones. Por lo tanto, el trabajo previo a la escritura de esta tesis, fue el de pensar cuidadosamente qué lenguaje y metodología será de utilidad pero que a su vez no eclipse las ropas de Alexander McQueen con teoría pura. Con frecuencia, los académicos teóricos que se enfrentan al fenómeno de la moda se olvidan de la infinidad de hechos materiales que pueden dar lugar a cambios dentro del universo de interpretación de una prenda; por otro lado, aquellos escritores más empíricos se resisten a la teoría. Afortunadamente, poco a poco estos métodos de trabajo han ido cambiando, logrando un balance. Mi personal atracción hacia el trabajo de este diseñador, por los materiales que utiliza para la confección y la búsqueda de significados y significantes dentro de un marco teórico particular, modestamente intenta contribuir a que la balanza permanezca estable.

Este trabajo no busca dar cuenta del presente de la moda sino más bien desarrollar un caso de estudio a través de un eje conductor en específico. No pretendo examinar todos los aspectos y tipos de moda contemporánea sino como se dijo, enfocar la

\footnotetext{
${ }^{1}$ Para información de este tipo consultar a los siguientes autores: Michelle Pastoureau, Cally Blackman, Joan DeJean, Matt Tyrnauer, Armando Chitolina, Suzy Menkes, Paul Poiret, N.J. Stevenson, Bronwyn Cosgrave, Viollet-le-duc, Victor Gay, Quicherat, Gilles Lipovetsky, Emmanuelle Polle, LaLonnie Lehman, Dominique y Francois Gaulme, Irving Wohlfarth, Stephen Greenblat, Lynda Nead, Valerie Steele.
} 
producción de un diseñador para demostrar la presencia del concepto de lo siniestro a través de una metodología que se basa en un análisis cualitativo e interpretativo de imágenes entendidas como algo que,

"aunque no siempre sea visible, se vale de ciertos rasgos visuales y depende de la producción de un sujeto. Imaginario o concreto, la imagen pasa por alguien que la produce o la reconoce.,"

En ese sentido, la imagen que la obra de McQueen produce, me permite retomarla para reflexionar sobre lo siniestro. Como lo afirma Martine Joly en su libro Introducción al análisis de la imagen, el término imagen se ha utilizado también para hacer referencia a las actividades psíquicas como las representaciones mentales. De esta manera queda claro que hay varias teorías que pueden abordar la imagen: la estética, el arte, la semántica, la sociología, la retórica y el psicoanálisis, entre muchos. Mi forma de abordar este trabajo es a partir de ciertos aportes de la semiótica (complementados con distintos enfoques metodológicos que se irán viendo a lo largo del desarrollo) al considerar su modo de producción de sentido, el cómo provoca significaciones e interpretaciones desde los signos plásticos como colores, formas, composiciones internas y discursos. Al intentar descifrar el mensaje en las obras mismas lo que hago es observar, examinar, comprender lo que despierta en los espectadores y comparar con otras interpretaciones posibles sin descartar, y más bien tomando como eje conductor, la evolución del concepto de lo siniestro que se formula en las prendas.

Así, el método que pongo en práctica -partiendo de los significados para encontrar los significantes y entonces los signos que componen la imagen- me permite demostrar que la obra de McQueen está compuesta por distintos signos tanto lingüísticos como icónicos y plásticos que construyen una significación global que integra el término de lo siniestro. Muchos de los elementos percibidos encontrarán su significación no solamente por estar presentes sino también por la ausencia de otros elementos que se pueden encontrar por asociación mental.

La autora del libro Adorned in Dreams: Fashion and Modernity, Elizabeth Wilson escribió que,

"la moda es parte de los sueños del mundo capitalista y de los de su economía."3

\footnotetext{
2 Joly, Martine. Introducción al análisis de la imagen. La Marca Editora. Argentina, 2012. Pp. 17.

${ }^{3}$ Wilson, Elizabeth. Adorned in Dreams: Fashion and Modernity. Ed. Virago, Londres, 1985. Pp. 14. (Traducción propia).
} 
Fue la lectura de la anterior cita la que en parte me demostró que el trayecto que estaba por recorrer rendiría interesantes frutos y que al tratar de escribir sobre moda, debía ir más allá de los conceptos economicistas y de consumo que rodean el tema, y mirar hacia áreas de conocimiento y de estudio diferentes a los emprendidos por otros autores. La aplicación del psicoanálisis será el enfoque adecuado para encontrar conexiones que puedan explicar la presencia de lo siniestro en la producción de McQueen. Para lograr tal empresa tuve que recurrir a las obras del padre del psicoanálisis -Sigmund Freud-, pero también de autores contemporáneos que han intentado analizar la moda desde el mismo punto de vista. Alison Bancroft, Barbara Creed, Rebecca Arnold, Elizabeth Wilson, Jonathan Dollimore, entre otros, hacen grandes aportaciones al tema y me ayudarán a sustentar mi hipótesis, pues sus teorías y herramientas son fundamentales para llegar al esqueleto que yace debajo de las prendas.

El estudio sobre el trabajo de McQueen realizado por los autores mencionados habla de un cuerpo -aquel que alude la producción del diseñador, por supuesto- que exhibe síntomas de trauma lo que hace que las ropas comiencen a existir de manera independiente y marginal -debido a la presencia de esos indicios- a lo que es usualmente aceptado en el mundo de las pasarelas. Es a finales de los años noventa en donde se encuentra la mayor producción de McQueen. Los temas y los materiales que utiliza a lo largo de ese tiempo son cada vez más oscuros y están usualmente permeados por temas de muerte, enfermedad, deterioro y abandono. El imaginario visual de las prendas que utiliza constantemente articula ansiedades, al mismo tiempo que aquello que ha sido denominado como los placeres de la identidad, la alienación y la pérdida que se da como resultado del rápido cambio social, económico y tecnológico de finales de los noventa.

Durante los años de la producción de McQueen, se habló de moda al límite, de moda urbana y experimental, en el que las angustias propias de cambio de milenio eran expresadas. Fue ese sentimiento de malestar el que da como resultado la articulación de conceptos opuestos como la belleza y el horror, el sexo y la muerte, los cuales vistos en retrospectiva disparan la necesidad de ser observados para abordar ansiedades contemporáneas, nuevas especulaciones sobre el cuerpo y responder si la angustia que se sintió en aquellos tiempos ha podido ser superada o si al contrario, se ha agudizado de tal manera que lo siniestro (como contraparte a esta serie de parejas dicotómicas) se halla mucho más cercano de lo que creemos a las teorías sobre la moda. 
A pesar de que por lo general no es el papel de los diseñadores de moda el especular sobre temas de identidad en el mundo, algunos sí lo hicieron. Durante ese periodo (Londres de los años noventa) en el que las ideas sobre la identidad en el ser humano parecían ser inestables, o cambiaban de forma vertiginosa, fue precisamente Alexander McQueen quien se interesó en reubicar su trabajo y el de la moda para construir imágenes y significados. Es posible sostener que similares condiciones se dieron previamente en dos momentos y lugares específicos: en la Viena del fin-de siècle $y$ en el París de los años treinta. Cada uno de esos momentos, con sus problemáticas y sensibilidades distintas, tienen en común que en las tres ocasiones se pudo identificar que la moda jugó un papel importante en la construcción y estructuración de aquellas preocupaciones contemporáneas concernientes a la identidad y al mundo.

Filósofos existencialistas ${ }^{4}$ argumentan que el ser humano con una identidad descentrada (y por lo tanto se podría añadir, angustiado), más allá de ser un producto singular y propio del pensamiento contemporáneo, es sencillamente la reiteración de la idea de la desintegración del ser humano luego de darse cuenta de la brevedad y futilidad de su existencia. Es decir, la supuesta crisis del individuo es una inestabilidad recurrente. ${ }^{5}$ El hombre siempre se ha visto en crisis en la tradición occidental sintiéndose atraído hacia delante por las fuerzas de la mutabilidad y la muerte. ${ }^{6}$ Por lo tanto, si esta "crisis" ha sido una constante en nuestra tradición, no cabe la menor duda de que se ha escondido particularmente y de manera formidable y travestida en los vestidos de McQueen.

Sostengo que muchos de los elementos característicos de las prendas diseñadas por Alexander McQueen tienen sus orígenes, por lo menos conceptuales, en el desarrollo del capitalismo mercantil del siglo XIV y en lo que el sociólogo Norbert Elias llama "el proceso civilizante."7 Para Elias, la evolución de los modales desde la Edad Media comprendía una represión de los comportamientos instintivos y agresivos a favor de un ser más desarrollado, reflexivo y controlado. Es, desde esta perspectiva, que la

\footnotetext{
${ }^{4}$ Se consideran precursores de esta corriente a Schopenhauer (El mundo como voluntad $y$ representación) y Nietzsche. Aunque la palabra existencialismo todavía no era usada en su época, el pesimismo y los rasgos del movimiento son característicos de sus obras. Es el filósofo danés Kierkegaard quien abre el camino para el existencialismo, en donde la desesperación y la angustia son necesarias para el hombre pues las considera el trayecto hacía la fe y la salvación, temas presentes en su Tratado de la desesperación. Por su parte, Sartre en El ser y la nada habla sobre la angustia en la que se basa la vida del ser humano que se adquiere con la consciencia de la muerte. Martin Heidegger, si bien no puede caracterizárselo estrictamente como existencialista, con su vasto trabajo filosófico es parte de estas reflexiones y en especial en su libro El ser y el tiempo.

${ }^{5}$ Dollimore, Jonathan. Death, Desire, and Loss in Western Culture. The Penguin Press, Londres, 1998. Pp. 19.

${ }^{6}$ Ibid. Pp. 23.

${ }^{7}$ Elias, Norbert. The Court Society. Ed. Blackwell, Oxford, 1983.
} 
moda puede estar hablando de lo que somos, fuimos y podríamos haber sido, al mismo tiempo que de aquello que ha sido reprimido y que nos remitirá sin duda a los estudios que Freud ha hecho sobre esto y el particular papel que tiene la represión en la comprensión de lo siniestro. Con respecto a esto, Gilles Lipovetsky dice que la moda es socialmente reproductiva, entrenándonos a ser flexibles y a responder al cambio -lo único constante- en el mundo,

"La moda socializa a los seres humanos para el cambio y los prepara para el reciclaje perpetuo."8

Por lo tanto, como lo plantea Anthony Giddens, al no ser más el objeto de burlas por superficial, frívola y engañosa, la moda adquiere un papel importante no solamente en el adorno del cuerpo sino también en la construcción de un individuo moderno y reflexivo. ${ }^{9}$ Pero si la moda en su ámbito más comercial y mainstream es parte de ese proceso de civilización también lo es en sus manifestaciones más experimentales y avant-garde, capaz al mismo tiempo de resistirse y oponerse a dicho proceso civilizante.

Es en ese espacio marginal del discurso oficial en el que la moda "experimental" trabaja con lo que se ha mantenido oculto y que ahora se manifiesta como un síntoma neurótico. Tal como lo ha planteado Michel Foucault en su Historia de la sexualidad mientras producimos un ser disciplinado y controlado por medio de la tecnología de los modales lo que ha sido reprimido en el proceso retorna como un trance (un trance que, intentaré mostrar es la presencia de lo siniestro), bajo el peso de algún trauma cultural del cual la moda experimental funge como una especie de memoria narrativa. Visto de esta forma, la moda es histérica, ${ }^{10}$ puesto que puede ser un síntoma de alienación, pérdida, luto, miedo al contagio, a la muerte, a la inestabilidad y al cambio. En ese sentido se podría afirmar que tal como el psicoanálisis, la moda investiga el dominio y la configuración de la incoherencia, discontinuidad, irrupción y desintegración. ${ }^{11}$

\footnotetext{
${ }^{8}$ Lipovetsky, Gilles. The Empire of Fashion: Dressing Modern Democracy. Trad. Catherine Porter. Princeton University Press, 1994. Pp. 149. (Traducción propia).

${ }^{9}$ Giddens, Anthony. Modernity and Self-Identity: Self and Society in the Late Modern Age. Polity Press. Cambridge, 1991.

${ }^{10} \mathrm{El}$ concepto de histeria tiene una historia larga y bien ilustrada dentro de la medicina y el pensamiento occidental. La noción greco-romana de la histeria o útero móvil -un órgano que deambula por el cuerpo de la mujer causando enfermedades- era el responsable de lo que perturbaba a las mujeres. En la Edad Media se pensaba que el origen de la histeria era el haber tenido relaciones sexuales con el diablo. Fue en el Renacimiento que se le ofrece una explicación médica y se le atribuye a los nervios. Fue durante el siglo XVIII y XIX que la histeria se convirtió en un concepto moralizador usado como mecanismo de control de la sexualidad femenina. Es con Freud que la histeria se convirtió en una enfermedad mental y se le asoció con un estado psíquico femenino.

${ }^{11}$ Abraham, Nicholas y Torok, Maria. The Shell and The Kernel. Vol.1. University of Chicago Press, Chicago y Londres, 1994.
} 
Resulta necesario aclarar que, si bien la moda experimental y el psicoanálisis trabajan con los deseos y los miedos reprimidos, no se trata de ninguna manera de los deseos y los miedos de los diseñadores mismos, en este caso Alexander McQueen. Mi tesis localizará los síntomas en los elementos utilizados en las prendas producidas y no en los motivos e intenciones del autor. Las ropas que aquí se verán están relacionadas a lo siniestro a partir de ellas mismas por medio de rastros que volverán como fragmentos materiales dentro de la producción. La obra de McQueen es oscura y sombría porque vista desde el presente da señales de las preocupaciones del momento en el que fueron hechas y que ahora retornan en el análisis con apariencia siniestra. Es decir, aquello que parecía en su momento articular una preocupación genuina no ha dejado de serlo sino que ahora resurge como algo familiar pero extraño. Alexander McQueen se interesa por explorar otras emociones y experiencias humanas y expresarlas en sus creaciones.

Con esto en mente, en las siguientes páginas llevaré a cabo un recorrido visual de las vestimentas, pero antes, para poder hacerlo es necesario tener presente siempre que las sensibilidades contemporáneas hacen eco de algunos momentos de la modernidad, como lo fue el crecimiento del capitalismo mercantil en la Europa del siglo XVII y su desarrollo hasta un acelerado consumo de comodidades culturales de las ciudades industrializadas del siglo XIX. Si se descontextualiza el estudio es poco probable que pueda comprenderse el anclaje del concepto de lo siniestro en este análisis. De manera que resulta necesario hacer breves comparaciones y comentarios a lo largo del trabajo sobre los cambios de la sociedad para poder entender y explicar el presente.

El concepto de modernidad es sin duda problemático y tal vez demasiado usado. Algunos historiadores, entienden la modernidad como una ruptura con la sociedad anterior a la sociedad industrial capitalista, utilizan el término para poder englobar los grandes cambios sociales y culturales que se llevaron a cabo a mediados del siglo XVI y en adelante en Europa. Para Max Weber los orígenes del capitalismo se basan en la ética Protestante en la cual lo más importante es la modernización y el racionalismo, metas que al ser puestas en acción desprenden un sentimiento de ambigüedad. ${ }^{12}$ Considero que para poder entender, en un primer momento, el término de lo siniestro y para en una segunda instancia hacerlo recorrer las prendas, es muy importante no perder de vista precisamente ese concepto de ambigüedad pues propone una íntima

\footnotetext{
12 Turner, Bryan. Theories of Modernity and Postmoderniy. Ed. Sage. Londres, 1990.
} 
conexión entre opuestos. La belleza y el horror, la desesperanza y el optimismo, familiar y extraño, orgánico e inorgánico, animado e inanimado, etc.

Por su parte, Rebecca Arnold dice que es intrínseco a la moda ser contradictoria, pues

“...despliega la promesa y la amenaza del futuro... revelando tanto nuestros deseos como nuestras ansiedades... construyendo identidades que utilizan la moda como un camino de auto-creación y finalmente, de auto-destrucción."13

Con esta cita, me gustaría también recordar en esta introducción a Walter Benjamin, pues resulta útil para entender mejor el sentido de ambigüedad, (noción que forma parte -veremos- integral de lo siniestro). Benjamin describe en uno de sus trabajos el momento en que dibuja un diagrama de su vida utilizando la forma del laberinto y propone que esta metáfora de la historia permite la yuxtaposición de imágenes históricas con aquellas contemporáneas; mientras el laberinto se dobla sobre sí mismo se revela que lo más moderno tiene una gran relación con lo más antiguo. Puntos distantes en el tiempo pueden verse o sentirse próximos en momentos específicos al momento en que sus caminos se encuentran. ${ }^{14}$ Esta metáfora me permite utilizar el laberinto aportando la posibilidad de la repetición y del resurgimiento de aquello que se ha mantenido reprimido u oculto. El recorrer de la historia que se dobla y desdobla sobre sí misma permite de igual forma la re-lectura y el análisis inclusive, de elementos que parecen resistirse al paso del tiempo y que retornan. Es decir, los rastros del pasado suben a la superficie del presente en el retorno de lo reprimido, haciendo que el uso del laberinto sea de gran importancia pues sienta las bases para un estado de ánimo intelectual que más adelante ayude a comprender las complejas estructuras de lo siniestro.

Para Michel Foucault la historia no es una descripción lineal que guarda su propio sentido al ser descrita; más bien es algo que, al ser analizada, permite ver que en lugar de una esencia existen puñados de acontecimientos antes ocultos. La historia no es más que una serie de sucesos fortuitos que no guardan ningún telos director. De ahí que deba entenderse como algo azaroso, ya que los códigos y principios que caracterizan a una época siempre proceden de

"accidentes, mínimas desviaciones, errores, malos cálculos." 15

\footnotetext{
${ }^{13}$ Arnold, Rebecca. Fashion, Desire and Anxiety: Image and Morality in the Twentieth Century. I.B. Tauris, Londres y Nueva York, 2001. Pp. 15. (Traducción propia)

${ }^{14}$ Benjamin, Walter. Escritos autobiográficos. Alianza Editorial. Madrid, 1996.

${ }^{15}$ Foucault, Michel. Nietzsche, la genealogía, la historia. Pre-textos. Valencia, 1997. Pp. 27-28.
} 
El objetivo de la genealogía es determinar qué tipos de relaciones pueden ser establecidas entre las distintas formas de clasificación social, pero se trata de hacerlo sin recurrir a ningún esquema mayor, sin ninguna teoría última de causalidad. Así pues, el estudio de la historia no es el de su desarrollo progresivo, sino el de sus diversos campos de constitución y validez. La verdad no es más que un artificio empeñado en definir las cosas "como son"; sin embargo, el genealogista descubre que detrás de toda pretensión última del conocimiento, el descubrimiento de la verdad, se encuentran ocultos modos y actos de perversión, como el instinto, la pasión, la crueldad y la injusticia de los que definen las cosas "como son".

Si como él lo propone, toda la historia es escrita desde la perspectiva del presente, en el sentido en que el ahora es el que determina cuáles serán los temas a estudiar históricamente, entonces la actualidad está en constante transformación y por lo tanto el pasado debe ser continuamente re-evaluado para que de esta forma tome nuevos significados a la luz de los eventos recientes. Sobre la base de la postura expresada por Foucault denominada como "genealogía" o la historia escrita a la luz de nuevas preocupaciones ${ }^{16}$ justifico la vuelta al análisis de la producción artística de Alexander McQueen y el re-evaluarlo bajo distintos conceptos y modelos de lectura. Esta idea foucoultiana comprende bastante bien lo que el trabajo del diseñador británico propone: el mostrar las complejas transmisiones entre el pasado y lo presente, lo reprimido y lo que resurge, lo que alguna vez fue familiar y lo que ahora se ha tornado extraño y los fragmentos y rastros que resuenan en el presente de la obra. Tal como lo plantea Benjamin y Marcel Proust en sus obras, los objetos son poseedores de emociones, huellas del pasado y transportadores de discursos de otros tiempos hacia el presente.

A partir de esta premisa, intento demostrar que los trabajos analizados en esta tesis son portadores de significados que se despliegan simultáneamente hacia el pasado y hacia el futuro. Es este movimiento el que permite traer hacia el presente elementos que han permanecido ocultos y que se manifiestan en las prendas provocando la presencia de lo siniestro. Este doble movimiento no auto-excluyente hace tácito el

\footnotetext{
${ }^{16}$ Foucault, Michel. La arqueología del saber. Siglo Veintiuno Editores. México, 1970. En este sentido es importante hacer uso del trabajo de Edgardo Castro titulado El vocabulario de Michel Foucault. Un recorrido alfabético por sus temas, conceptos y autores, pues como él bien aclara, a diferencia del concepto de arqueología, la genealogía a la que hago referencia no tiene una obra metodológica en si misma escrita por Foucault. El desarrollo de este concepto se da a lo largo de varios de sus trabajos dedicados al poder (Vigilar y castigar, entre otros). Foucault no entiende a la genealogía como una ruptura si no como una ampliación de la arqueología para escribir sobre la historia a como lo he referido en mi trabajo, en donde la genealogía parte de un principio de discontinuidad en el que no hay discursos predeterminados, absolutos e inamovibles.
} 
concepto de ambigüedad, término central para comprender el eje conductor de este estudio y que explicaré en los siguientes capítulos.

El psicoanálisis es una disciplina muy particular pues desde su concepción ha seguido dos trayectorias paralelas y simultáneas. Por un lado, se adentró en el ámbito de la clínica en donde se le considera la cura hablada para personas con algún tipo de aflicción mental y por otra parte, llegó al mundo intelectual en donde se le ha puesto a dialogar con las formas y prácticas creativas para investigar lo que significa ser un ser humano. Sin embargo, luego de investigar bastante, pareciera no haberlo hecho demasiado con la moda, es más, la literatura al respecto es poca. La mayoría de lo encontrado está centrado en la fotografía y en la ideología visual que éstas proponen. Otros textos hablan de la moda y el cuerpo haciendo referencia a la manera en la que ambos se entrelazan. Algunos más hacen referencia al poder erótico que tiene el vestido. ${ }^{17}$ Mi trabajo intentará otro acercamiento.

Una de las razones de la falta de material escrito se encuentra en la moda en sí misma y su naturaleza comercial. Pero es a partir de creaciones como las de Alexander McQueen que la moda cambia tanto en la forma en la que se concibe a sí misma como en las nuevas articulaciones de elementos que la conforman. Ciertamente a partir de McQueen, la moda cambió y se le otorgó un mayor énfasis en la creatividad en lugar de darle prioridad a ser simplemente un objeto de consumo. El mismo McQueen es citado en un artículo escrito por Judith Mackrell para el periódico The Guardian en su sección de artes, quejándose de que los diseñadores eran considerados como

$$
\text { "perros falderos de señoras que toman el almuerzo."18 }
$$

A partir de su trabajo, se abre un camino en el que la moda debió haber entrado desde hace tiempo. Al igual que sucede con la literatura en donde los críticos no se enfocan en el negocio editorial, ¿por qué no comenzar a hacer lo mismo con la moda? Los críticos de arte y los académicos no se interesan en los vendedores de arte sino en el objeto mismo. Siguiendo la misma lógica considero pertinente que la obra de McQueen, como parte del mundo de la moda, deje de ser considerada como objeto

\footnotetext{
${ }^{17}$ Para textos relacionados con estos temas dirigirse a los trabajos de: Diana Fuss y su artículo de 1992, titulado "Fashion and the Homospectatorial Look." en Critical Inquiry ; Molly Ann Rothenberg y Joseph Valente de 1996, titulado "Fashionable Theory and Fashion-able Women" en Critical Enquiry, ; Kaja Silverman y sus trabajo sobre la moda en novelas, cine y en el trabajo de Richard Avedon; Megan Grant con sus escritos sobre adolescentes australianos y las interpretaciones que hace de éstos a partir del trabajo de Julia Kristeva. Dani Cavallaro y Alexandra Warwick hablan del cuerpo y el psicoanálisis en Fashioning the Frame: Boundaries, Dress and the Body (1998); el texto de J.C. Flügel, The Psychology of Clothes (1930) y el de Edmund Bergler, Fashion and the Unconscious (1953).

${ }_{18}$ Mackrell, Judith. "The name's d'Eon. Chevalier d'Edon". The Guardian. 19 de febrero de 2009. Sección Artes. Pp. 21. (Traducción propia).
} 
exclusivo de consumo propio del capitalismo y comience a mirársele también con un enfoque estético y creativo aumentando su consideración en el mundo de la crítica y la academia de arte.

Si bien la moda es extremadamente dependiente de las estructuras económicas y sociales puede y lo ha mostrado, cambiar desde sus entrañas y lo hace precisamente donde se une con el arte y el psicoanálisis volviéndose provocativa y disruptiva ante el discurso imperante. Con tal objetivo, la moda se presenta en este trabajo como una forma creativa, realizada sí a partir del cuerpo pero al mismo tiempo independiente de él. Al comprenderla como un lenguaje creativo e interpretarla por medio del psicoanálisis y la estética es posible leerla de una manera innovadora.

Las ropas que McQueen confecciona tienen las mismas características de la mujer que comenzó a vislumbrarse en el siglo XIX. Es la naturaleza de esta mujer la que permite que las telas cobren vida propia. Fue Baudelaire quien en El pintor de la vida moderna distinguió por primera vez tal asociación y se percata de un cambio rotundo en el camino de la moda, dando cuenta de que ésta ya no solamente se utiliza para distinguir las clases sociales sino también para diferenciar los géneros y apunta:

“¿Qué poeta osaría, al pintar el placer causado por la aparición de una belleza, separar a la mujer de su vestido? ¿Quién es el hombre que, en la calle, en el teatro, en el bosque, no ha disfrutado, de la manera más desinteresada de un vestido sabiamente arreglado, $y$ no se ha llevado una imagen inseparable de la belleza de aquella a la que pertenecía, haciendo así de las dos, de la mujer y del traje, una totalidad indivisible?"19

Puede verse en este pasaje el modo como por primera vez la moda se toma en cuenta de manera separada a la historia de la vestimenta, sugiriendo que tiene un lugar en el discurso artístico y se la sitúa en la práctica estética moderna. Muchos discutirán que la moda no es arte puesto que depende enteramente del ser usada pero como mencioné anteriormente pretendo mostrar perspectivas según las cuales la moda puede ser analizada en términos estéticos. La idea de que puede ser distinta a la vestimenta en tanto que hace uso de propiedades estéticas es primordial para el análisis de McQueen. Lo que quiero decir, es que la moda, vista desde una perspectiva estética, puede ser analizada como un discurso artístico al mismo tiempo que mantiene su naturaleza de objeto de consumo.

Antes de proceder con el desarrollo de este nuevo acercamiento, tiene que tenerse en cuenta que si bien es cierto que en una primera instancia a la moda se le considera una forma de expresar la identidad personal, una tendencia dentro de los productos de

${ }^{19}$ Baudelaire, Charles. El pintor de la vida moderna. Librería Yerba, Murcia, 1995. Pp. 120-121. 
los negocios y las marcas, también es necesario entender que su principal preocupación es la de la innovación en el campo de la decoración de la superficie del cuerpo y las amplias respuestas sociales y culturales a este tema. Por lo tanto, es obvio que se piense que es justamente quien la porta y el acto de llevarla puesta lo que se considera central en el ámbito de la moda. Es común entender que la vestimenta no puede ser independiente, que es una entidad que se superpone en el cuerpo de la mujer y que existe solamente durante el proceso de ser usada. ${ }^{20}$

La mayor parte de lo escrito sobre moda y psicoanálisis se refiere a este tema. Considero que la moda puede, y debe, ser leída desde otros ángulos y contextos en los que la prenda no depende del uso y como consecuencia se vuelve autónoma. Es precisamente esta nueva visión la que la coloca bajo una luz distinta y lo que tiende a provocar una sensación inquietante. Sobre esta cuestión, Elizabeth Wilson dice:

"Las ropas, sin el que las porta, ya sea en un stand, en un contenedor de cristal, o meramente tiradas en el suelo como las prendas de los amantes, pueden afectarnos de manera desagradable, como cuando una serpiente ha cambiado de piel."21

Sin duda para los efectos generales de la moda el portador es un elemento imperativo en toda la operación, pero para efectos de este análisis, las vestimentas que McQueen confecciona mantienen una sensación que parece alejarlas de toda relación corporal hasta convertirlas en ropas espectrales, en el sentido en que existen más allá del cuerpo y en consecuencia de su incapacidad de ser usadas como prendas de uso cotidiano. Al utilizar el modelo psicoanalítico se podrá dar cuenta de que la moda, una experiencia corpórea que opera tanto en lo visual como en lo lingüístico puede ser entendida sin comprometer ninguna de las paradojas en las que parece estar basada. También se podrá ver que la moda puede ser experimentada íntimamente cuando es usada y cuando no lo es. Sus formas pueden crear distintas percepciones, algunas similares y en muchos casos experiencias opuestas. Lo espectral en ellas es que habitan y existen sin la necesidad de ser usadas y porque remiten a lo inanimado e inorgánico. Vistas de esta manera, lo siniestro vuelve a aparecer, pues como lo afirma Freud,

“...lo siniestro sería aquella suerte de espantoso que afecta las cosas conocidas y familiares desde tiempo atrás."

\footnotetext{
${ }^{20}$ Para fines de esta tesis doy por supuesta esta relación de moda y mujer pero está claro que en la actualidad moda y masculinidad van también de la mano pero eso sería tema de otro trabajo.

${ }_{21}$ Wilson, Elizabeth. Adorned in Dreams: Fashion and Modernity. Ed. Virago, Londres, 1985. Pp. 2. (Traducción propia).

22 Freud, Sigmund. Lo siniestro (1919). Obras completas. Amorrortu Editores. Buenos Aires, 1991.
} 
Sin embargo, este trabajo no será puramente psicoanalítico pues como posteriormente bien apuntaba Lacan en sus estudios, las posibilidades interpretativas del psicoanálisis no deben de ser atenuadas por las diferencias genuinas e integrales entre pacientes y formas creativas. Me parece muy adecuada la siguiente afirmación de Lacan en que,

“...el psicoanálisis sólo se aplica como tratamiento, y por tanto, a un sujeto que habla y escucha."23

Con lo anterior en mente esta tesis trabaja con los vestidos de McQueen, leyendo ciertas instancias de la moda a través de la teoría del arte dentro de un marco conceptual psicoanalítico para obtener algunas posibles interpretaciones de los vestidos del diseñador inglés, los cuales representan uno de los trabajos creativos más profundamente desafiantes y recalcitrantes de estos tiempos.

Este trabajo comienza con el primer capítulo en donde se trata de algunos elementos y situaciones definitorias para el surgimiento de la relación entre el arte y la moda. En esta sección se repasarán los primeros pasos dados por la moda para incursionar en el ámbito museístico durante la década de los ochenta. Se presentará también ejemplos de trabajos de diseñadores que exploraron con sus prendas el mundo del arte y de artistas que decidieron hacer uso de los recursos de la moda para formar discursos. A continuación se define el término avant-garde y su uso en el arte y la moda a partir de los trabajos de teóricos como Greenberg, Burger, Graham y Foster, así como el desarrollo del neo avant-garde y la moda como discurso.

Se expondrá los comienzos de la moda y de su principal exponente Charles Frederick Worth, así como la influencia de la industrialización durante éste tiempo en el campo de la moda y del arte. Se explicarán los resultados de tal acontecimiento y de cómo afectó a los artistas y diseñadores, pasando por el Bauhaus y el constructivismo para demostrar la forma en que la moda se tornó campo de trabajo creativo para los artistas. Se revisará a Theo Van Doesburg (De Stijl), Hans Jean Arp (Dadaísmo), Andy Warhol y Joseph Beuys.

Se procederá a plantear la ruptura de los límites entre el arte y la moda a partir de la obra de ciertos artistas y de la incursión de diseñadores en el arte a partir de los años ochenta y de los distintos campos donde esto sucedió: bienales, tiendas de ropa que funcionaban como galerías de arte, museos con exhibiciones retrospectivas de

\footnotetext{
${ }^{23}$ Lacan, J. Función y Campo de la Palabra y del Lenguaje en Psicoanálisis, Escritos 1, Buenos Aires, Siglo XXI editores, 1988. Pp.247.
} 
diseñadores y el trabajo de artistas feministas que exploran las posibilidades de la moda.

Se aclarará el origen de los estudios de moda a partir de los trabajos de investigadores como Georg Simmel, Thorstein Veblen y Walter Benjamin quienes escribieron algunas cosas sobre la moda y de la manera en que la modernidad se manifiesta en ella. A partir de este punto se podrá comprender la razón de que haya muy pocos tratados sobre moda que aporten a la estética. Se citarán los trabajos de Karen Hanson y su explicación a tal falta de literatura al respecto. Asimismo, se revisará lo propuesto por Anne Hollander, historiadora que presenta el único intento serio de ver a la moda como un arte visual a partir de los experimentos estéticos y las innovaciones que han surgido por parte de los diseñadores. Además, se discutirá el planteamiento de Hollander desde la perspectiva de Llevellyn Negrin y Paul Sweetman, quienes le critican que la conexión con el cuerpo no debe ser olvidada pues eso solamente ayuda a perpetuar más la separación con el arte.

A partir de la noción establecida por estos dos últimos autores se presentara por primera vez el concepto de lo siniestro como puente de unión entre la estética y la moda tomando en cuenta al cuerpo para fortalecer el concepto de moda como arte y no para excluirla más.

Para poder comprender lo anterior se advertirán una serie de consideraciones previas, la cuales son: lo propuesto por Barthes quien distingue entre la naturaleza material de la ropa y lo que la vestimenta representa; lo escrito por Jean Baudrillard y su postura ante la moda; el trabajo de Bourdieu y sus investigaciones sobre el gusto y el consumo. Finalmente lo expuesto por Benjamin sobre la moda como agente de cambio.

Este capítulo cerrará con los antecedentes de lo siniestro haciendo un brevísimo recorrido de las categorías estéticas y examinando el papel del siglo XVIII en la construcción del concepto. Se discutirán algunas ideas de la teoría de la Einfühlung, la cual abre paso para la llegada del psicoanálisis, su interés por los procesos psíquicos y su intención de explicar racionalmente lo sobrenatural.

El segundo capítulo inaugura de facto los antecedentes del concepto freudiano de lo siniestro a partir del estudio del ensayo que lleva el mismo nombre. Luego, se analizará la etapa de conceptualización de lo siniestro a partir del trabajo de Anneleen Maschelein y la explicación de las re-lecturas del texto de Freud por otros teóricos. 
Igualmente, se verá la postura de la lingüista Claudine Normand acerca de la utilización de conceptos psicoanalíticos para la creación de nuevas teorías.

El apartado continuará con lo siniestro y su relación con otras categorías estéticas como lo sublime y lo fantástico, denotando los principales postulados que lo caracterizan para poder elaborar un primer acercamiento de lo siniestro en la prendas de Alexander McQueen. Al hacer esto, se dilucidará la importancia del surgimientos de la cultura neo romántica en la época de los ochentas y finales de los noventa, justo el tiempo del comienzo de la producción de McQueen. Asimismo, se explicará la estabilización durante esta misma época del concepto y su consecuente expansión como resultado de las nuevas lecturas del ensayo original de lo siniestro a la luz del advenimiento del nuevo milenio.

Se mostrará la entrada del término al dominio del arte a partir de dos trabajos fundamentales en este sentido: el texto de Nicholas Royle dedicado a lo siniestro en la literatura y el catálogo de exhibición del artista Mike Kelly sobre el concepto en la artes visuales. A continuación, se presentarán los dos principales ejes que recorre lo siniestro en ese momento: el primero siendo el camino de la estética con los trabajos de Sara Koffman y su relectura del texto de Freud y el énfasis que coloca sobre el tema del doble y lo oculto; la obra de Hans Lehman y el retorno a lo primitivo y oculto y lo que se entiende en términos de shock; lo expuesto por Louis Vax sobre lo siniestro en la literatura fantástica y Wolfgang Kayser con lo grotesco. El segundo eje, revisará brevísimamente una línea post-marxista en donde lo importante radica en el sentido de alienación y angustia de la sociedad.

El segundo apartado concluirá con un recorrido sobre distintas acepciones de lo siniestro desde lo propuesto por Harold Bloom, Julia Kristeva, Rosemary Jackson y varios artistas, para terminar con un concepto que a finales de milenio se presenta como herramienta teórica y como inspiración para la creación artística.

Es de esta manera que se llegará finalmente a la presentación en su totalidad del concepto de lo siniestro a partir de un recorrido cronológico del término, sus diferentes acepciones desde el trabajo de distintos autores, las relaciones que mantienen con otros conceptos estéticos y su conexión básica con el psicoanálisis.

El tercer capítulo se enfoca completamente en el análisis de la producción del diseñador británico Alexander McQueen para develar la presencia de lo siniestro. Para esto, se hace una serie de relaciones con algunos elementos y situaciones socio- 
culturales definitorias para el surgimiento del concepto como la invención del barómetro, el texto del siglo XVIII titulado El Esposo Femenino, la novela Los misterios de Udolfo de Anne Radcliffe y la aparición de los fantasmas a partir de la invención de la linterna mágica y la espectralización de los pensamientos. Todos topos determinantes de algunas de las características de la retórica de lo siniestro que se ven expuestos en las prendas del diseñador.

La descripción, aunque breve, es importante ya que constituye el movimiento de las codificaciones de las percepciones visuales hacia el lenguaje escrito. Esta conversión del mensaje visual pone en manifiesto procesos de elección perceptivos. Para el análisis de este trabajo los signos plásticos de las ropas -las formas, los colores, las texturas, las poses de las modelos, los maniquíes y las puestas en escena- son importantes. A partir de estos se pondrá en manifiesto las connotaciones que los acompañan y que claramente delinean lo siniestro. Finalmente, logrando una complementariedad entre todos los componentes de la obra y que consiste en otorgarle una significación que parte de ella pero que no por eso le sea intrínseca. Se llegará a una interpretación, que va más allá de las prendas y que desencadena un discurso interior basado en lo siniestro en donde la obra sirve de soporte pero de la que al mismo tiempo se desprende. Es desde este método de análisis que quedará claro que la complementariedad de las imágenes y sus mensajes reside en el hecho de que se alimentan unas de otras. Por esta razón, a lo largo del último capítulo se harán referencias a otros momentos históricos y a otros trabajos.

La parte final de esta tesis la compondrán las conclusiones en las cuales sintetizaré los resultados de esta investigación, de tal modo que se pueda apreciar lo obtenido a partir de la demostración de mi hipótesis. De la misma forma, se incluirá aquello que se considera lo más importante dentro del desarrollo de la investigación y finalmente, se resaltarán los aportes que la investigación otorgó al campo en específico de la estética 


\section{La moda y el arte. Diseñadores artistas y artistas diseñadores}

En febrero de 1982, la revista Artforum publicó en su portada el trabajo del diseñador de moda Issey Miyake. (Placa 1) Fue este momento el que marcó el comienzo de la transición de la moda hacia el espacio de la galería. Así, se inauguraron una serie de exhibiciones en museos como el Metropolitano de Nueva York, el Louvre, el Victorian and Albert Museum en Londres, el Guggenheim y el Musée de Mode en París dedicadas a la moda. Sin embargo, a pesar de que los museos le abrieron sus puertas para atraer al público, la moda dentro del contexto museístico siguió siendo considerada inferior con respecto al arte.

Otro hito de esta nueva relación entre arte y moda se dio en 1987 cuando la artista Jana Sterbak produjo una obra titulada Vanitas: Vestido de carne para un albino anoréxico (Placa 2) la cual se compone de varios pedazos de carne cruda confeccionados de tal manera que en su conjunto forman un vestido. Según la artista, la representación simbólica de este trabajo subraya el concepto del cuerpo como la ropa del alma. Además, aún con la carne ya seca y decolorada, la obra está repleta de una furia feminista hacia la objetivización del cuerpo de la mujer y representa la falta de confianza de las mujeres hacia sus propios cuerpos como resultado de la sobreidentificación con las imágenes representadas en los medios, al mismo tiempo que hace hincapié en la producción de los cuerpos de las mujeres como un tipo de mercancía que lleva a la auto-ficcionalización y a la enfermedad.

Los ochentas inauguran de lleno la relación del arte con la moda pero ya desde el trabajo de Paul Poiret, ${ }^{24}$ los diseñadores de ropa se han visto influenciados por las obras de arte y algunos artistas han buscado trabajar en colaboración con modistos. Fue esta relación tan directa entre el cuerpo y la creación lo que fascinó a artistas como Salvador Dalí y que los atrajo a la esfera del diseño de modas.

Cuando se revisa la historia de la moda del siglo XX -época en la que la relación entre la moda y el arte tuvo su mayor auge- queda claro que denominar a la moda como frívola e inferior al arte es un argumento ingenuo, impreciso e injusto. Esta investigación no está dirigida a plantear una discusión sobre si la moda es arte o no. El objeto de estudio son las ropas del diseñador Alexander McQueen las cuales, dentro del mundo mismo que las engendra, son denominadas como prendas de alta

\footnotetext{
${ }^{24}$ Poiret fue uno de los diseñadores avant-garde más influyentes de comienzos del siglo XX. Luego de trabajar en el atelier de Worth, estableció su propia casa de ropa, especializándose principalmente en estilos orientales. Igual que su antecesor, se consideraba a sí mismo un artista.
} 
costura y avant-garde. Si bien este concepto ha circulado por más de un siglo en las artes, en la moda se ha utilizado para designar solamente a aquellos diseñadores que han superado todas las expectativas tradicionales de la industria de la moda. Se sabe que originalmente era un término militar para designar a un pequeño grupo de avanzada cuyo propósito era el de explorar el nuevo territorio e ir marcando el camino para los que venían atrás. Con el tiempo se utilizó para referirse a un modo artístico en particular que ocurre en distintos puntos de la historia del arte moderna. Varios movimientos artísticos desde el Dadá hasta el arte conceptual son considerados avant-garde, sin embargo éste no debe confundirse con un movimiento artístico en sí mismo. Este es un término que nombra a aquellas prácticas artísticas que se diferencian de las políticas culturales en las que operan.

En su ensayo de 1939 titulado Avant-garde y Kitsch Clement Greenberg observa el término como una defensa en contra del populismo y lo considera elitista. Desde su punto de vista, el avant-garde es una parte del dualismo del arte. El concepto ha sido visto por él, y por otros como Rosalind Krauss, como una crisis de originalidad en el arte y marca la oposición entre lo original hecho a mano y lo producido en masa. ${ }^{25} \mathrm{Sin}$ embargo, según Greenberg lo más importante para el término no es si el objeto es o no arte sino su selección y ubicación.

Mientras que para Greenberg el avant-garde es opuesto por default a lo que se da en el momento, para Peter Bürger ${ }^{26}$ esa oposición tienen que ser activa, es decir, el autor argumenta que para que el concepto sea visto tiene que ser un acto político que rechace a la comercialización burguesa del arte y que de hecho niegue a la institución del arte. Por su parte, Gordon Graham, define al avant- garde como intencionalmente innovador, radical y subversivo, tendiendo a generar una reacción negativa casi siempre que se le mira por primera vez. ${ }^{27} \mathrm{Hal}$ Foster dice, por otro lado, que hablar de neo-avant-garde en el siglo XX es interrogarse sobre la repetición, pues sin duda en el arte de este siglo la reapropiación es recurrente y sugiere una continuidad entre el avant-garde original que va desde 1910 hasta 1920 y el actual, y a diferencia de Bürger, cree que el concepto en realidad habla de un contínuum y no de rompimientos sino de un movimiento de repetición y desdoblamiento. ${ }^{28}$

\footnotetext{
${ }^{25}$ Greenberg, Clement, O'Brian, John. The Collected Essays and Criticism. University of Chicago Press. Chicago, 1986.

${ }^{26}$ Bürger, Peter. Theory of the Avant-Garde. University of Minnesota Press. Minneapolis, 1984.

27 Graham, Gordon. Philosophy of the Arts: An Introduction to Aesthetics. Routledge. London, 2005.

${ }^{28}$ Foster, Hal. The Return of the Real: The Avant-Garde at the End of the Century. MIT Press, Cambridge,1996.
} 
Es desde esta perspectiva y no desde si es arte o no, que tomo el trabajo de McQueen medio de expresión y exploración para analizar la presencia de lo siniestro. Ya existen diversos escritos que debaten de mejor manera la postura de si la moda es arte. Estas polémicas se han enfocado por más de un siglo en el objeto de arte y en el producto de la moda sin detenerse a mirar los marcos teóricos lingüísticos que le permiten a uno ser arte y al otro moda. El argumentar que esto se debe a que uno se usa y el otro no es sólo una parte del discurso, al igual que decir que el arte puede algunas veces ser usado. El arte y la moda son definidos, o si se prefiere, habitados por sistemas completamente diferentes. Son estos aparatos intelectuales los que los definen como discursos separados pero intercambiables. Es decir, la moda y el arte ocupan diferentes modalidades de presentación y recepción, tienen diferentes usos y están sujetos a diferentes respuestas dentro de la economía del deseo y la monetaria pero ambos son creaciones estéticas para los cuales el acercamientos siempre es subjetivo. Si algo nos ha ensañado la historia del arte desde Marcel Duchamp es que el arte no puede existir sin los elaborados protocolos que se registran por parte del espectador. La revolución que sobrevino a la obra de Duchamp despojó al objeto artístico del significado inherente y lo convirtió en un artefacto cultural cuyo estatus es otorgado a partir de una delicada red de signos y acuerdos.

La moda, como discurso, sistema y área de estudio, aun conteniendo nociones tales como vestido, disfraz y ropa, es sin duda una entidad histórica. Esto es muy parecido a cuando se piensa en la idea del arte como una actividad llevada a cabo por individuos o grupos especializados que producen objetos estéticos o experiencias diferentes a las cotidianas. Ambos campos emanan de una configuración social de clase, capital y comunicación que comienza a finales de la Edad Media y el Renacimiento, un período que presenció el alejamiento de las rígidas estructuras religiosas y de gobierno hacia nuevas formas de movilidad y auto-propiedad. Igual que el dinero, la moda y el arte son agentes simbólicos pero sus niveles de transacción son diferentes.

El diseño de moda comenzó en 1850 con el trabajo de Charles Frederick Worth y fue justo entonces cuando se comenzó a especular acerca del nexo entre moda y arte. Este es el momento en que la ropa empezó a asumir el estatus de objeto sustancial que de manera casual utilizaba el cuerpo humano como soporte para ser activado. El talento de Worth y su fuerte auto promoción fueron importantísimos para colocar a la moda en un puesto avanzado dentro de la sociedad. El diseñador se esforzó mucho -pues sabía que era por su propio bien- por establecer la noción de 
creación en el proceso de diseño de una prenda y por convertir al diseñador en artista. Esta idea ya se encontraba pero de manera incipiente en el siglo XVIII salvo por una pequeña diferencia: en ese siglo, la excelencia de la prenda tenía que ser igual al estatus de la persona que la usaba mientras que durante la época de Worth la moda se convirtió en un medio de progreso social. Las personas consumían la creatividad de Worth como un bien para distinguirse. ${ }^{29}$

Las prendas preciosistas de Worth perdieron su fuerza con la industrialización y con las simplificaciones que resultaron del diseño japonés consumido por la sociedad del momento que necesitaba ropa más sencilla que fuera más acorde a su movilidad y actividad. El arte también resultó afectado por el potencial de la industrialización, lo cual se vio en movimientos como el Futurismo y el Constructivismo. Tal como lo encarnó el Bauhaus, varios grupos artísticos en Europa estaban más que conformes con borrar las distinciones entre el arte y el diseño pues lo que se quería lograr era la producción de objetos bellos y funcionales destinados a un mejor estilo de vida. Luego de la Segunda Guerra Mundial, este ideal fue abandonado y la relación entre el arte y la moda tuvo un retroceso. Mientras que el avant-garde artístico quiso llenar a la moda con sus propios objetivos a seguir, ésta ayudada por las masas, técnicas fotográficas más sofisticadas y la creación de telas sintéticas comenzó a robar el léxico del arte su historia, normas, retórica, alusiones e inclusive sus estrategias- como medio de instaurarse a sí misma en el ámbito de la calidad y excelencia.

En el siglo XX, la moda se volvió uno de los campos de trabajo para los artistas pues muchos de ellos comprendieron su poder de provocación al crear identidades. Theo van Doesburg, el líder del movimiento De Stijl, usaba un traje negro, corbata y calcetines blancos para representar lo negativo que había en la noción de las prendas cotidianas. El dadaísta Hans Jean Arp (Placa 3) creaba trajes enormemente elaborados como una especie de oposición a la vestimenta tradicional. Andy Warhol con su peluca blanca y lentes (Placa 4), Joseph Beuys con su tradicional chamarra de pescador y sombrero (Placa 5) planteaban la primicia de que

"la manera de verse era tan importante como el arte mismo., 30

De esta forma, el debate de si la moda es arte o si hay arte de moda se terminó durante los años sesenta debido a los artistas del movimiento Pop en los Estados

\footnotetext{
${ }^{29}$ Worth fue esencial para la creación de la imagen de la moda como arte, pero fue capaz de lograrlo dentro de un contexto histórico muy particular en el cual la moda en general se democratizaba cada vez más. Además de definirse como un artista y a sus prendas como obras de arte para una clientela de elite fue el primero en colocarle etiquetas con su nombre a las ropas.

${ }^{30}$ Müller, Florence. Art and Fashion. Ed. Thames and Hudson. London, 2000. Pp. 12.
} 
Unidos y en Gran Bretaña quienes se aseguraron de suavizar las distinciones entre alta y baja cultura negándose a distinguir entre la reproducción de una pintura de la vieja escuela y un personaje de cómic. Esto sería algo de lo que la moda se beneficiaría y con lo que el arte tendría que competir. Durante esta época Yves Saint Laurent incursionó en el mundo del arte con su trabajo inspirado en Piet Mondrian. Sus vestidos de lana y túnica consistían en líneas negras que se intersectaban en distintos puntos y en bloques sólidos de colores primarios con formas geométricas (Placa 6). Al año siguiente, su colección Pop incluyó un vestido largo de color negro con unos labios a la altura del pecho. Para el diseñador, artistas como Mondrian y Warhol le ofrecían la inspiración que necesitaba para la pasarela. Por su parte, Warhol, quien comenzó su carrera como ilustrador de moda para revistas como Harper's Bazaar, Vogue y Mademoiselle, creó una serie de vestidos en papel titulados The Souper Dress (1966-1967), los cuales estaban influenciados por sus pinturas de las latas de sopa Campbell's (Placa 7). Mientras Yves Saint Laurent exaltaba el glamur y la seducción del arte en la moda, el vestido de papel de Warhol hacía una crítica sobre el consumismo a través de la transgresión de las fronteras entre el arte, la moda y el mercado.

Para finales de los ochenta y comienzos de los noventa, la moda y el arte se unían por medio de una mutua fascinación. Las bienales exponían trabajos en donde artistas y diseñadores colaboraban. Además, las tiendas de grandes diseñadores en muchas ocasiones emulaban galerías de arte, tal fue el caso de la boutique en París de Yohji Yamamoto o la de Rei Kawakubo en donde inclusive se presentaban exhibiciones de arte. Los museos, por su parte, dejaron entrar a la moda a partir de exposiciones retrospectivas de la producción de diseñadores. Por si fuera poco, las artistas feministas empezaron a encontrar una veta de exploración interesante. Cindy Sherman en su trabajo titulado Fashion Series se autorretrataba vistiendo ropas de Jean Paul Gautier, Issey Miyake y Jean Charles de Castelbajac (Placa 8). En esta serie, Sherman utilizó la moda para explorar las ideas y los conceptos que construyen la representación de la mujer en el mundo de la moda. El diálogo entre el arte y la moda alcanzó su apogeo en los noventa cuando las vidrieras, las pasarelas y las exhibiciones en los museos se volvieron los sitios por excelencia para exponer a la moda. Así, los diseñadores se vieron cada vez más atraídos hacia la práctica artística y la moda conceptual surgió a partir de las nuevas tecnologías y de las innovaciones estéticas que empezaban a ser más importantes que la practicidad, funcionalidad y utilidad de la prenda. De esta manera, surgieron diseñadores que se negaron a comprometer su visión creativa por el mercado. 
Los estudios de moda surgen básicamente de tres disciplinas: la antropología, la etnografía y la historia del arte. Esta división es fundamental pues una parte se enfoca en las configuraciones culturales y la otra enfatiza las cualidades formales y estéticas que se pueden percibir a partir del análisis de estudios de pinturas y dibujos realizados a partir del siglo XVI en Venecia hasta el siglo XIX en Londres y París. Teóricos de la cultura como Georg Simmel, Thorstein Veblen y Walter Benjamin escribieron sobre la moda y fueron capaces de mostrar cómo ésta era uno de los medios principales por los cuales la modernidad se manifestaba. De acuerdo a estos autores, la moda es un cristal en el que la estética, el consumo, la clase social, la industria y la identidad personal se unen. ${ }^{31}$

\section{Origen de los estudios de moda e investigaciones actuales}

Más allá de algunos pocos trabajos que se escribieron durante las últimas dos décadas, no se puede hablar en realidad de grandes aportes al tema. Esta área de investigación aún puede ser explorada desde una gran variedad de discursos. Hasta el momento, la moda no ha sido de interés para el campo de la estética. Por su inevitable asociación con lo exterior y el uso, la moda no fue ni ha sido considerada digna de reflexión estética. De hecho, hay muy pocos teóricos que se han aventurado a mirar a la moda desde este campo para que sea tomada en cuenta como arte y tratar de aplicarle los conceptos filosóficos de la estética y la metodología de la historia del arte para analizarla.

Karen Hanson en su artículo titulado Dressing Down Dressing Up: The Philosophic Fear of Fashion sugiere que una de las razones primordiales por los que la filosofía se ha negado a reflexionar sobre la moda es que ésta no puede ser disociada del cuerpo tan fácilmente. Desde su perspectiva, Hanson dice que la inevitable conexión de la moda con el cuerpo la coloca en conflicto directo con la aspiración de la filosofía de trascender el campo de los intereses subjetivos y los deseos personales. Ella lo dice así,

"La moda llama la atención sobre ilusiones basadas en la corporalidad. Lo último que olvidaría es su conexión con el cuerpo. El vestido es inseparable de éste-aún cuando metal o piedras

\footnotetext{
${ }^{31}$ Benjamin en El libro de los pasajes argumentó que esto también era el caso del arte pero de diferente manera, es decir, los modos de expresión no son los mismos ni tampoco la relación que ambos tienen con la producción y el consumo. Básicamente, la moda y el arte se diferencian en cuanto a la intención y a la expresión.
} 
sean utilizados en prendas, sus características estéticas están conectadas al cuerpo. Los filósofos ante esto comenzarán a sentir una especie de indecencia en tales reflexiones." ${ }^{\text {"32 }}$

En la tradición estética esta preocupación de separarla de todo lo que tenga que ver con el cuerpo y sus deseos y placeres físicos ha sido recurrente. Lo efímero que hay en la moda parece contraponerse desde el comienzo con las preocupaciones de la filosofía que busca verdades y valores que perduran en el tiempo.

La historiadora de arte Anne Hollander ha sido la única en tratar de romper con la exclusión de la moda en el arte al decir que el vestido es una forma de arte visual argumentando que el propósito principal de la moda no es práctico y utilitario solamente sino que también es un ejercicio creativo cuyos cambios se deben a imperativos estéticos más que a funcionales, económicos, sociales y políticos. Además, propone dejar de hacer una historia del vestido a partir de las clases sociales y demás factores sociales y concentrarse en una historia que hable de los experimentos estéticos y las innovaciones que han surgido en los diseñadores. Ella dice,

"La moda es un arte moderno debido a que sus cambios ilustran la idea de un proceso, tal como lo ha hecho el arte moderno; la moda hace su propia secuencia de imágenes a partir de sus propios medios y su propia historia. No crea simplemente un reflejo de los hechos culturales.,33

Desde este punto de vista, la moda sí se diferencia de la vestimenta tradicional, la cual la autora considera que se ve más afectada por los factores sociales. Mientras que las prendas comunes están relacionadas con la costumbre y expresando algunos significados sociales, la moda es mucho más auto-reflexiva. Al traer y usar elementos del pasado, los vacía de su significado original, utilizándolos en primera medida como una forma estética en la que se experimenta el efecto visual. Así, emancipada de cualquier tipo de demanda social, la moda representa un nivel superior de alcance estético que el de la ropa tradicional y que es parecido al movimiento que fue de la representación a la abstracción en el arte moderno en donde los artistas comenzaron a explorar cuestiones estéticas independientemente de la necesidad de imitar los objetos del mundo exterior.

Sin embargo, a los argumentos anteriores otra autora le ha encontrado fallas que son interesantes de conocer. Llewellyn Negrin, en su trabajo referente a la moda afirma

\footnotetext{
32 Hanson, Karen. Dressing down Dressing up: The Philosophic Fear of Fashion. Hypatia Vol. 5, No. 2, Feminism and Aesthetics (Summer, 1990), pp. 107-121.

${ }^{33}$ Hollander, Anne. Sex and Suites: The Evolution of Modern Dress. Alfred \& Knopf. New York, 1994. Pp. 15.
} 
que a pesar de que lo que plantea Hollander es un paso importante para comenzar a discutir la inclusión de la moda en la estética, su defensa es problemática en tanto que está basada en la concepción Kantiana de la estética como una contemplación desinteresada de la forma. La autora le contesta diciendo que tal noción no le ayuda en nada a la moda pues se sustenta en una concepción de la forma incorpórea. Además, le responde que al ver a la moda como una forma de arte visual, se olvida de la importante conexión que ésta tiene con el cuerpo logrando que se perpetúe aún más la separación de la mente y el cuerpo. Negrin también culpa al museo de alejar a la moda del cuerpo pues éste jamás ha sido tomado en consideración al momento de la exhibición de prendas. Añade que a esto se le suma la tendencia que tienen los análisis de moda a no tomar en cuenta el cuerpo. Nunca se habla de la experiencia que tienen las personas que usan las prendas. No se hace referencia jamás a las formas táctiles que se pueden experimentar al portar las ropas. Por lo tanto, lo que Negrin y otros autores como Paul Sweetman proponen, es que se escriba sobre la moda como una técnica del cuerpo la cual impacta no sólo nuestra propia experiencia corporal sino también las formas en las que el cuerpo puede ser usado. ${ }^{34}$

Como ya mencioné en la Introducción, mi trabajo de análisis de las prendas de McQueen propone ser un primer aporte a la inclusión de la moda al campo de la estética sin tener que separarla del cuerpo para poder ser reconocida como arte. Para poder llevar acabo esto hago uso del concepto psicoanalítico de lo siniestro como una especie de puente que une a estos campos de trabajo. Para lograrlo me resulta necesario comprender a la moda desde ciertos parámetros ya explorados. Uno de estos es lo aportado por Barthes ${ }^{35}$ al discurso de la moda: el de hacer la distinción entre la naturaleza material de la ropa y lo que la vestimenta representa. Al hacer esto, Barthes identifica el lugar de valor que define al sistema de la moda como una forma o atributo de la organización social sobre una serie de funciones utilitarias. Tanto la ropa (la prenda real) como la moda (lo representado) atienden necesidades, y sin embargo, la moda se hace responsable de una serie de preocupaciones que unen al deseo inmaterial con los materiales de consumo. Entiendo que esta conexión entre el consumo y el deseo es lo que distingue a la economía moderna de las anteriores y lo que define al arte moderno del previo. Algo similar pasó con la moda y que no puedo dejar de lado antes de tratar de incluirla a una reflexión estética.

La ropa pre moderna era ceremonial o contingente. Si no demostraba el status social de la persona, sea este un noble, un oficial o un religioso, entonces estaba

${ }^{34}$ Geczy, Adam. Karaminas, Vicki. Fashion and Art. Berg. London, 2012.

${ }^{35}$ Barthes, Roland. El sistema de la moda. Gustavo Gili. Barcelona, 1971. 
limitada a lo que se podía pagar o encontrar. Se dice que la moda comenzó alrededor del siglo XIV, cuando los nobles empezaron a querer diferenciarse del resto de manera más audaz y arbitraria. De igual forma, cuando se habla de arte en términos del discurso de la modernidad, se comienza en el mismo siglo, cuando los artistas dejaron de atender a las necesidades de la iglesia y siguieron caminos más personales. ${ }^{36}$ La percepción de que el arte empezaba a tocar otros terrenos se dio a finales del siglo XVIII. El escritor Louis-Sébastien Mercier en su Tableau de Paris hace referencia a como la moda se torna cada vez más importante y como se ve influenciada por el arte. De esta forma, los actos de duplicación de la moda y de apropiación de aspectos del arte la colocan en esa zona de la que hablaba Barthes, aquella de representación y de imaginación. Las ropas se convierten en algo más que en ropa; se han transformado en sistemas complejos de significantes que se basan en la seducción, es decir, se han vuelto moda. Desde este momento en adelante, la idea de la moda es cuando las personas ya no compran zapatos o ropas para calzarse o vestirse y trascienden lo utilitario entronándose dentro de sus propios principios y valores. Jean Baudrillard en su libro titulado Crítica a la economía política del signo considera a la moda desde el estudio del consumo, como lógica de intercambio de signos y producción de diferencias, planteando que un objeto se convierte en uno de consumo cuando los objetos se autonomizan como signos diferenciales; separado de sus funciones como herramienta, de sus características mercantiles de producto y se ve liberado a la lógica de la diferenciación. Es decir, nunca hay objeto de consumo sino hasta el momento en que éste se cambia a partir de una ley social dentro de una escala de status. ${ }^{37}$ Así la moda es el objeto de consumo por excelencia. Siguiendo esta línea de pensamiento, no es de extrañar que la moda comenzara a suponer o afirmar la posición social de las personas. Pierre Bourdieu en su conocidísimo texto titulado La distinción explica la manera en que se desarrollan las investigaciones sobre el gusto y el consumo y hay un paralelismo entre el recorrido de la moda y la distinción que otorgan ciertos objetos de consumo. La moda, y en especial la alta costura como la que hace Alexander McQueen, es especial y constituye un lujo inaccesible para los ocupantes de un nivel o clase inferior, mientras que para aquellos que sí pueden acceder a estas prendas hay un constante sentimiento de dirigirse y buscar objetos

\footnotetext{
${ }^{36}$ El momento más representativo de eso fue durante la Francia de Luis XIV. Lo que hizo diferente el régimen de este rey al de sus antecesores fue no solamente la gran dimensión de sus esfuerzos sino también la cada vez mayor forma de auto-conciencia en que el arte, la arquitectura y la moda servían como representaciones del poder del estado. Un gran ejemplo del poder de la corte y de los privilegios de los que gozaba era el uso ropas orientales. Los materiales y telas exóticas eran tremendamente costosos y difíciles de conseguir, por lo tanto, eran solamente accesibles a aquellos que pudieran costearlos. Estos gustos en las ropas se trasladaron a la pintura, porcelanas, etc.

${ }^{37}$ Baudrillard, Crítica de la economía política del signo. Siglo XXI. México, 1989.
} 
siempre nuevos sin descartar lo tradicional, que es lo que les otorga la distinción, es decir, esa no necesidad obvia por lo nuevo que debe romper con el pasado. ${ }^{38}$

Jean Baudrillard en este aspecto plantea interesantes aportaciones al tema. En su libro titulado El intercambio simbólico y la muerte afirma que la moda solamente es posible dentro del marco de la Modernidad pues es durante este periodo que se introduce dos tiempos que a su vez son simultáneos: el tiempo lineal del progreso y la historia, y el cíclico de la moda en donde conviven lo tradicional y lo nuevo sin jamás haber una ruptura entre ellos. En este sentido, la moda, según Baudrillard, es el emblema de la Modernidad pues representa lo que se entiende por objeto de consumo y por ser capaz de sostener dos líneas de tiempo simultáneamente. ${ }^{39}$

Otro de los parámetros interesantes a tener en cuenta es el propuesto por Walter Benjamin quien nombró a París como la capital del siglo XIX. Benjamin y algunos surrealistas como André Breton y Luis Aragón, consideraban la ciudad como un tejido complejo, heterogéneo y lleno de innumerables posibilidades. Un lugar con incontables estratos históricos inconscientes, es decir, un macrocosmos de la mente. Auto-denominándose como barómetros urbanos, pensaban que el vagar por las ciudades era parte de su trabajo como intelectuales y artistas. La moda jugó un papel importantísimo en este aspecto pues era el agente de cambio. Estos intelectuales sabían que la ciudad era el lugar perfecto para todo tipo de engaños de la percepción y la ilusión, y por lo tanto la moda ocupaba un lugar privilegiado, pues permitía darse cuenta de esto. Lo que a estos pensadores les interesaba especialmente era que las personas no eran lo que parecían ser. Una noble era en realidad una cortesana, un caballero era un mayordomo, etc. tal como pasaba en el siglo XVIII en los bailes de disfraces. De ahí viene lo que la moda ha estado usando como una de sus principales características: el enmascaramiento. A partir de estos momentos históricos se puede notar que la moda no es solamente la producción de ropas pues se encuentra íntimamente relacionada con el tiempo, con las reconfiguraciones del cuerpo y lo que lo rodea, potenciando su habilidad de plantear preguntas sobre la identidad y mostrando su capacidad de reflejar lo que pasa en la cultura y la sociedad.

Son precisamente estos temas sobre el tiempo, el deterioro, las constantes interrogantes de quiénes somos, el qué y cómo se pueden lograr distintas reconfiguraciones sobre el cuerpo lo que fascinaba a Alexander McQueen. Este diseñador tomó por el camino de la exploración del lado marginal de la vida. Su trabajo

\footnotetext{
${ }^{38}$ Bourdieu. La distinción. Criterio y bases sociales del gusto. Ed. Taurus. Madrid, 1988.

39 Op. Cit. El intercambio simbólico y la muerte. Monte Ávila Editores. Caracas, 1980.
} 
es considerado avant-garde en el sentido en que rompe con el establecimiento de la moda y revela una alta costura que expresa mayores intereses al de la vestimenta tradicional. McQueen no busca solamente vestir, sus prendas hablan de crueldad y de una sexualidad femenina que es terrible y aterradora. Horror que devela un movimiento psíquico mucho más sutil pero que desde mi punto de vista es más violento y es en realidad lo que amedrenta a los que miran los vestidos del diseñador. Por debajo de esas enormes fauces castradoras se encuentra el ligero devenir de lo siniestro.

\section{El advenimiento de lo siniestro}

Para poder hablar sobre las prendas de Alexander McQueen, para comprender de cierta manera esa característica siniestra que las rodea y hace posible su inclusión en el campo del arte y por lo tanto susceptible a la reflexión estética es importante establecer ciertas precisiones sobre el concepto de lo siniestro al mismo tiempo que ubicarlo dentro del contexto y del análisis estético de las producción de McQueen.

Es en el siglo XVIII durante el cual el largo camino recorrido por los estudiosos de la estética finalmente da lugar a un estudio mucho más fructífero sobre la gran variedad de matices que se pueden encontrar en la estética que incluye categorías hasta el momento incapaces de formar parte de un goce artístico.

Durante la época del pensamiento cristiano, las categorías hechas por la estética adoptan definitivamente un sesgo teológico espiritual y metafísico acentuando el alejamiento de lo bello respecto del mundo sensible, reduciendo la belleza presente en el mundo real a ser un mero símbolo del poder y la bondad divinos. La belleza se identifica, con el ser supremo que crea el mundo de manera análoga a como el artista humano realiza una obra de arte, conforme a leyes exactas que confieren a todas las partes del cosmos una perfecta disposición, dotando al conjunto de un gran esplendor que en él se observa. De ahí que toda la estética medieval esté absolutamente imbuida de teleología, toda vez que, para los pensadores de este período, la belleza del mundo depende de la finalidad que lo atraviesa, introducida en él por un artífice sumamente sabio y perfecto.

Será hasta la llegada de Kant, que la intención de superar tanto el objetivismo estético, metafísico y dogmático, como el subjetivismo relativista llevará a cabo un giro en el terreno de la estética, al centrar su atención sobre el problema del juicio del gusto y las condiciones transcendentales que lo hacen posible. Las consecuencias de este 
cambio de dirección fueron muy importantes, pues el arte se independizó por primera vez de la imitación de la naturaleza y pasaba a ser el espíritu del artista el lugar desde el cual la naturaleza da reglas al arte. El genio creador y su libertad espiritual debían oponerse radicalmente a la simple imitación.

El camino emprendido por Kant condujo a ver en los fenómenos estéticos una manifestación más de la infinita productividad del sujeto y de cómo la realidad se concibe en una suerte de creación poética resultado de la creatividad. De esta manera, los estetas del Romanticismo entenderán esa creatividad en términos místicos y cuasi religiosos. En esta corriente también el arte es entendido desde el punto de vista del absoluto, viéndose en él un tipo de oficio divino, una representación simbólica de lo infinito en lo finito, una prolongación, en definitiva, del proceso creador del mundo efectuado por el espíritu, que encuentra su reflejo en la capacidad creadora del genio individual.

Así, las ideas de la estética romántica, en su intento de abarcar todos los fenómenos, se ponen claramente de manifiesto en el complejo concepto de obra de arte total. Esta estética encontró su expresión definitiva en los grandes sistemas del idealismo alemán que en algunos autores llegó a verse, tanto en la estética como en el arte, el núcleo central de todo el sistema del pensamiento.

Por lo tanto, es desde ahora que se comprende y se acepta mucho más, que en el terreno de la estética resulta insostenible la pretensión de crear un sistema conceptual que encasille de manera absoluta todos los fenómenos, pues éstos se muestran cada vez más ricos y complejos y es en vano tratar de abarcar su infinita diversidad y que ya no sólo comprende a aquellos que remiten a la belleza.

Existen y se reconocen multitud de fenómenos que no pueden ser calificados de bellos y que, no obstante, tienen perfecto derecho a ser incluidos en una reflexión de este tipo. Así sucede con lo feo, el asco, lo grotesco, o con muchos objetos que poseen valores estéticos individuales, que no cabe identificar con la belleza, la sublimidad, o cualquier otra categoría estética general. De esta manera, lo bello comienza a no ser considerado como categoría fundamental de la estética, sino como un término genérico más entre muchos donde se clasifican predicados estéticos muy diversos.

La tendencia de la estética a centrar la atención en la experiencia del sujeto individual fue común durante el período ilustrado. Para este momento, la imaginación como 
capacidad psíquica capaz de fabricar mentalmente mundos posibles, y el placer estético que proporciona, constituyen las categorías fundamentales de la estética. Las consecuencias inmediatas de esta posición fueron, por un lado, la liberación del sujeto, que tiende ahora a exigir sus derechos en el terreno estético, prescindiendo de cualquier clase de reglas (genio); y por otro, la identificación del problema de lo bello con el problema del gusto, al que se considera un "estado psíquico específico e irreductible." 40

Surge así una estética que pretende ser empirista e inductiva, e intenta descubrir las leyes psíquicas que rigen los fenómenos estéticos partiendo de los sentimientos individuales de simpatía o repulsión, placer o displacer, agrado o desagrado, suscitados en el ánimo al contemplar un objeto. ${ }^{41}$

Al siglo XVIII se le considera un tiempo de avance y alumbramiento, mostrando una doble naturaleza de ambigüedad entre la razón y la superstición que rige todo el tiempo. El historiador Lecky fue el primero en describir de manera detallada como el nuevo espíritu racionalista logró que el antiguo sistema europeo de creencias basado en la magia y la superstición se volviera obsoleto a lo largo de los años 1650 y 1800. Lecky dice:

"No hay cambio en la historia durante los últimos trescientos años más sorprendente y sugestivo que éste y que se estime casi al borde de lo milagroso. Sin embargo, unos siglos atrás, la solución más utilizada para responder a la perplejidad era el milagro. El hecho milagroso era, entonces, universalmente aceptado como perfectamente creíble, probable y ordinario (...) Los poderes de la luz y de la oscuridad eran visiblemente observados mientras luchaban por el mando. Los milagros, las sanaciones sobrenaturales, las visiones, profecías y prodigios de cualquier tipo atestiguaban la actividad de uno, mientras que la brujería y la magia, con todos sus horrores eran las manifestaciones visibles del último." ${ }^{\prime 2}$

El historiador afirma que con la caída de las explicaciones teológicas el hombre fue capaz por primera vez de tratar estos temas con tranquilidad y en consecuencia producir puntos de vista más comprensibles y cambiar radicalmente la historia. Keith Richard apoya este planteamiento de Lecky en su libro de 1971 Religion and the Decline of Magic. Él también ve una transformación profunda durante el siglo XVIII en donde la creencia fuertemente arraigada en fantasmas, brujas, posesiones demoniacas, astrología, adivinación, etc. fue gradualmente remplazado por otro tipo de conocimiento ${ }^{43}$. Pero, a diferencia de Lecky, quien atribuye este cambio al aminoramiento de las pasiones religiosas, Richard lo sitúa en los cambios en la

${ }^{40}$ D. Hume. La norma del gusto. Teorema, Valencia, 1980, P.6

${ }^{41}$ D. Hume, Tratado de la naturaleza humana. Ed. Nacional, Madrid, 1981, Vol. II, 1, Sección VIII, P. 477.

${ }^{42}$ Lecky, W.E.H. History of the Rise and Influence of the Spirit of Rationalism in Europe. Appleton, New York. 1919. Pp. 27-28. (Traducción propia).

${ }^{43}$ Fue precisamente en 1736 que el parlamento inglés declaró ilegales todas las acusaciones de brujería, superando así las antiguas creencias. 
organización de los patrones sociales y el dramático efecto que esto tuvo en la conciencia humana. Sin embargo, he aquí en lo que se basan los autores que describen al siglo como oscuro, pues algo ocurre en esta época que entre más se buscó la "iluminación" más alienado se sintieron los hombres del mundo; por decirlo de otra manera, entre más buscó la humanidad liberarse de la superstición, el misterio y la magia, paradójicamente, las personas se sintieron más envueltas y arrasadas por un sentimiento de inquietud que tendría su origen en este siglo y que considero la antesala de lo siniestro.

Paralelamente a lo que sucedía en la sociedad, a nivel psicológico y experimental se plantea llevar a cabo un estudio de las vivencias estéticas penetrando en los procesos psíquicos que acompañan a los actos de contemplación y creatividad. La teoría de la Einfühlung es el nombre que se le da a este nuevo movimiento y que toma estos intentos de fundar la estética sobre presupuestos psicológicos armonizándolos. Será Gustav Fechner ${ }^{44}$ quien sienta las bases de este nuevo movimiento ligado al Romanticismo. Esta corriente trata, por primera vez, de superar los prepuestos de las teorías estéticas anteriores, uniendo el punto de vista subjetivo y el objetivo. Para la Einfühlung, la constitución de los objetos da lugar a una reacción subjetiva emocional que es luego proyectada hacia tales objetos que pasan de inmediato a cobrar valor estético.

La Einfühlung vio en la estética un estudio de las leyes de la vida psíquica individual que rigen la percepción, según la cual uno de sus postulados afirma que la proyección de emociones en el objeto estético parte exclusivamente del sujeto. Por consecuencia, la Einfühlung interpreta la experiencia estética invariablemente en términos psicológicos, como una animación del objeto consistente en trasladar a éste el dinamismo interno del sujeto; como una reflexión psicológica que presta al objeto las propiedades espirituales de la personalidad del sujeto; como una expansión o afirmación de la vitalidad del individuo, a partir de una determinada forma del objeto, vitalidad que el sujeto transfiere luego a éste, o como la captación sentimental, por parte del artista, de lo típico y esencialmente humano que es proyectado luego al objeto a través de medios simbólicos evocativos y asociativos (es esta última parte la que será retomada posteriormente por Freud, aunque con otros fines, y que ha sido utilizada en la teoría artística basada en el psicoanálisis para concluir que el arte es -

\footnotetext{
${ }^{44}$ Gustav Theodor Fechner (1810-1887) fue un psicólogo experimental y filósofo alemán, creador de la psicofísica. Pensó que cada materia estaba dotada de un espíritu y tuvo éxito para poner en relación el mundo del espíritu con aquél de la materia. Sus trabajos filosóficos concernientes a la estética son importantes pues intentó demostrar que ciertas formas abstractas son naturalmente agradables a nuestros sentidos.
} 
en algunas ocasiones- el síntoma por el cual se expresa lo reprimido que retorna a lo consciente).

La mayor parte de estas interpretaciones de los fenómenos parte de la idea de que la estética ha de centrarse exclusivamente en un estudio de los procesos anímicos y más concretamente de los procesos psíquicos que tienen lugar en la mente humana durante la creación o contemplación de un objeto dotado de valor estético.

En la ciencia y en la filosofía se intentaba encontrar un hilo conductor que explicara el proceso de interiorización de lo que alguna vez se pensaba fuera del sujeto y propio del objeto y que arrasaba cada vez más el inconsciente colectivo de la sociedad.

Los principales pensadores de este siglo trabajan sobre la idea del subjetivismo como la postura más coherente a seguir dentro de la estética. Todo el período llustrado tiene esta tendencia: la de centrar toda su atención en la experiencia del individuo. Como ya se vio, la imaginación es la capacidad psíquica capaz de fabricar mundos paralelos, y el placer estético que ésta proporciona constituye una de las categorías de las nuevas categorías de la estética ${ }^{45}$. Con este amplísimo rango de emociones que comienzan a surgir y con el nuevo predominio de la imaginación, todos los campos en los que el ser humano está envuelto se ven transformados.

Ante estos nuevos intereses y la necesidad de atrapar a estos fantasmas de la imaginación aparece el ensayo de lo siniestro de Freud pues su descripción sobre la experiencia psíquica y lo siniestro mismo ofrece una interesante perspectiva respecto a lo sobrenatural. Freud y el psicoanálisis se ven atraídos a explicar lo sobrenatural. El siguiente pasaje de La interpretación de los sueños da cuenta de eso:

"Los ladrones, los asaltantes nocturnos y los fantasmas de los que se siente miedo antes de acostarse y con los que luego se sueña a veces, proceden de una misma reminiscencia infantil. Son los visitantes nocturnos que han despertado al niño para ponerle en el orinal y evitar que mojase la cama o han levantado cuidadosamente las sábanas para observar la posición de sus manos durante el reposo. En el análisis de algunos de estos sueños de angustia he logrado que el sujeto reconociese la persona del visitante. El ladrón era, casi siempre, representación del padre, y los fantasmas correspondían más bien a personas femeninas vestidas con el largo camisón de dormir." 46

\footnotetext{
${ }^{45}$ Bosanquet, Bernard. Historia de la estética. Vol. III. Ed. Nueva Visión. Buenos Aires, 1961. Pp. 209210.

${ }^{46}$ Freud, Sigmund. La interpretación de los sueños. Madrid, Biblioteca Nueva, 1972.. Pp. 335.
} 
Los fantasmas ${ }^{47}$ para Freud han dejado de existir en todas partes excepto en la mente. Para él, son representantes (en camisón de dormir) de reminiscencias infantiles, visitantes del ámbito de la memoria inconsciente y la fantasía. Se piensa que el psicoanalista tiene el poder de despertar a estos espectros de una manera controlada y exorcizarlos. Podría pensarse, a partir de lo expuesto, que cualquier intento de domesticar un elemento demoníaco de la vida humana resultará inevitablemente en su retorno, en una recurrencia más intensa e inquietante.

Freud claramente marca a lo siniestro como un tipo específico de ansiedad. Dice,

"No cabe duda que dicho concepto está próximo a los dominios de lo espantable, angustiante, espeluznante, pero no es menos seguro que el término se aplica a menudo en una acepción un tanto indeterminada, de modo que casi siempre coincide con lo angustiante en general., ${ }^{48}$

Así, la experiencia de lo siniestro confronta a Freud con el hecho de que las personas pueden obtener placer estético a partir de la sensación de ansiedad. ${ }^{49}$

\footnotetext{
${ }^{47}$ Esos fantasmas son parte de lo que a finales del siglo XVIII se denominara como el efecto de fantasmagoría

48 Freud, Sigmund. Lo siniestro. Obras completas. Amorrortu Editores. Buenos Aires, 1991. Pp. 1.

${ }^{49}$ Freud reconoce dos formas de ansiedad, la real y la neurótica. La real responde a la percepción de peligro proveniente del mundo exterior o de la realidad, se puede decir que esta ansiedad es una expresión de un impulso de auto preservación. La segunda categoría, la que más interesa para poder asir el concepto de lo siniestro hasta donde sea posible, es la ansiedad neurótica, la cual puede presentarse de varias maneras. La neurosis ansiosa (una condición general de ansiedad y preocupación), la fobia (ligado a objetos específicos o situaciones) y finalmente el ataque de ansiedad (aquel que ya no está ligado con ningún tipo de peligro). Dentro de la primera teoría de la ansiedad, lo siniestro no puede ser del todo catalogado como ansiedad real o neurótica, pues claramente pertenece a ambas.
} 


\section{Lo siniestro}

Lo siniestro ${ }^{50}$ es un concepto que ha sido ampliamente utilizado en diferentes disciplinas, desde la literatura hasta el arte, desde la filosofía, la teoría cinematográfica, la arquitectura, la sociología y últimamente en el ámbito de la robótica y la inteligencia artificial. Mi trabajo propone ahora, incluirlo en la reflexión estética de la moda.

La primera definición que sentó las bases para este término fue aquella propuesta por Sigmund Freud en 1919 en su escrito titulado Lo siniestro y en el que afirma que,

"...lo siniestro causa espanto precisamente porque no es conocido, familiar."

Teresa del Conde en su ensayo titulado Freud y la estética. Una aproximación analiza la importancia del cuerpo de trabajo freudiano en el campo de la estética y afirma los siguientes postulados con los que estoy de acuerdo. En una primera instancia reconoce que el psicoanálisis es una herramienta importantísima para la comprensión del fenómeno artístico y el análisis de obras de arte. Así mismo, luego de una lectura global del trabajo de Freud concluye que la actitud del psicoanalista ante el arte y los artistas fue mutante y ambigua, pues,

"En ocasiones parece haber encontrado los orígenes que explican el fenómeno de la creatividad, y así lo expresa en forma contundente; pero en otros momentos asegura- a diferencia de sus más incautos seguidores- que no posee la solución a la respuesta planteada por "el dilema del arte".,52

En este sentido, entiendo que a pesar de que Freud utilizó ejemplos literarios y obras de arte para tratar de definir un concepto psicoanalítico no hay una teoría estética per se. Tal como lo plantea Del Conde, no es imposible generar una teoría de la estética a partir de algunos principios psicoanalíticos pero tal empresa no fue hecha desde un principio por Freud.

Fue en 2003 con el trabajo de Nicholas Royle titulado igualmente, Lo siniestro, que se comprende de lleno que el concepto se había ya expandido mucho más lejos que aquella primera acepción psicoanalítica y cuando se inaugura de facto lo comenzado por Freud. Para Royle, lo siniestro jamás se cierra y se convierte en una perspectiva

\footnotetext{
${ }^{50}$ A pesar de que tanto Freud como varios estudiosos han subrayado la noción de que la palabra unheimlich es imposible traducir dado su contenido y forma, algunos vocablos pueden expresar más o menos el mismo sentimiento. Términos como escalofriante, inquietante, sobrecogedor o el término francés inquiétante étrangeté, son los más cercanos. Los efectos, como bien lo plantea Freud son generalmente subjetivos pero también son objetivos en el sentido en que son reconocibles a lo largo de distintas culturas y épocas independientemente de las expresiones que se usen para categorizarlos. 51 Freud, Sigmund. Lo siniestro. Obras completas. Amorrortu Editores. Buenos Aires, 1991.

52 Del Conde, Teresa. Freud y la estética. Una aproximación. Revista Anales del Instituto de Investigaciones Estéticas. Vol. XIII. No. 49. Año 1979. Pp. 102.
} 
en general, una manera de pensar y de escribir, sinónimo de las enseñanzas deconstructivas. Así, para él, lo siniestro se vuelve algo insidioso que atraviesa cualquier tópico: desde la política, la historia, las humanidades, la tecnología, el psicoanálisis, la religión. Por lo tanto, desde esta perspectiva,

"Puesto que lo siniestro afecta y persigue todo, su naturaleza está en constante transformación y no puede ser definido completamente. Lo no familiar jamás está detenido y sí constantemente alterado. Lo siniestro es lo perturbador del término mismo. ${ }^{, 53}$

Lo anterior con respecto a Royle lo afirmo porque en muchos de los textos de Freud donde hace uso de referencias literarias o de obras de arte éste simplemente toma lo que le es indispensable y necesario para poder explicar lo siniestro como un fenómeno que le ocurre al hombre y no como afecto estético puro. Nuevamente, es solamente hasta el trabajo de Royle que se le concede a lo siniestro una naturaleza que puede llegar a ser considerada estética. Teresa Del Conde lo afirma de la siguiente manera,

"...Freud no muestra haberse dejado llevar por un placer estético, sino por un interés psicológico, y prueba de ello es que no sintió necesidad de analizar otras obras (...). Le bastó la que tomó como ejemplo para ilustrar un aspecto de su teoría sobre el retorno de lo reprimido.",54

J.M, Villagrán da cuenta del interés de Freud en la literatura como manifestación de actividad estética pero solamente como proceso dentro de una teoría general del psiquismo,

“...y excluyendo los problemas referentes a la psicología del arte y de la experiencia estética., Estas aclaraciones son necesarias de hacer antes de intentar definir el concepto desde el punto de vista de la estética y de querer encontrarlo en una obra plástica. Villagrán afirma que Freud no desarrolló o concibió de ninguna manera una teoría estética que definiera el papel desempeñado por el arte en la vida mental sino que más bien fue que algunas obras de arte al igual que ciertas conductas humanas le despertaban curiosidad por analizar. Así, no hay una aproximación estética en Freud pues no fue más allá de relacionar los procesos creativos a los impulsos y es relativamente reciente el pensar lo siniestro sólo como categoría estética.

\section{La conceptualización de lo siniestro}

De acuerdo a los trabajos de genealogía propuestos por Michel Foucault, entiendo este concepto no solamente -aunque sin dejarlo de lado- como un recuento histórico

\footnotetext{
${ }^{53}$ Royle, Nicholas. The Uncanny. Manchester University Press / Routledge. 2013. Pp. 10.

${ }^{54}$ Op. Cit. Pp. 107.

${ }_{55}$ Moreno Villagrán, J.M. El pensamiento estético en la obra de Freud. Rev. Asoc. Esp. Neuropsiq. Vol.XII. No. 41, 1992
} 
de los hechos que describen el desarrollo teleológico desde el comienzo hasta el final de lo que se comprende como siniestro, sino también como un mapa dinámico del proceso de conceptualización, es decir, un movimiento oscilatorio entre transiciones contingentes y aquellas motivadas, basado en huellas materiales de una consciencia conceptual encontrada en distintos tipos de discursos. Este tipo de genealogía también intenta comprender por qué la estructura conceptual de lo siniestro no es algo que pueda ser definido de manera precisa. Más allá de que este tipo de proceso genealógico no es indiferente a estas ambigüedades conceptuales, el principal objetivo de este trabajo es apuntar hacia una postura más amplia del concepto de lo siniestro mientras atraviesa ciertos momentos y se aplica a las ropas creadas por el diseñador inglés.

Desde los años sesenta hasta los ochenta se da un periodo de re-conceptualización de lo siniestro donde, según Anneleen Masschelein se sitúa la conceptualización per se de lo siniestro marcado por una conciencia conceptual que parte de una gran cantidad de análisis y re-lecturas a profundidad del ensayo de Freud desde varias perspectivas. Es a lo largo de este periodo que lo siniestro es sometido a grandes cambios. Teóricamente, nuevos significados le son añadidos logrando una especie de engrosamiento del tejido conceptual. En la práctica, lo siniestro es asociado con un tipo en específico de cuerpo de trabajo, varios estilos de narrativa y motivos, y con un modelo de lectura. Los factores que contribuyeron a este nuevo acercamiento hacia el concepto son varios. Dentro del pensamiento deconstructivo hay un gran interés por los textos marginales. El auge del surgimiento de la fenomenología, el estructuralismo y el post-estructuralismo, así como la hermenéutica tienden al uso de nuevos conceptos que funcionen de forma distinta a aquellos utilizados hasta ahora. ${ }^{56}$ Según la lingüista Claudine Normad, los conceptos psicoanalíticos pueden servir como modelos para una nueva ciencia en la que la teoría y la práctica se relacionen más. Así, las ficciones teóricas de Freud son consideradas metáforas en el sentido estricto de la palabra, es decir, no solamente descriptivamente sino que también dan una guía de interpretación y percepción de la realidad produciendo efectos que exceden cualquier definición conceptual. ${ }^{57}$

Es durante este periodo que también se dan movimientos discursivos en los que un intercambio semántico relaciona a lo siniestro con la estética y las nociones filosóficas

\footnotetext{
${ }^{56}$ Entre los primeros autores que comenzaron a utilizar conceptos "científicos" por su naturaleza metafórica se encuentran Claudine Normand y Neil Hertz.

57 Masschelein, Annelen. The unconcept. The Freudian Uncanny in Late Twentieth-Century Theory. Suny Press. United States, 2011.
} 
de lo sublime, lo fantástico y la alienación. Algunas de las raíces semánticas utilizadas por Freud al elaborar el concepto de lo siniestro -tales como la ambivalencia, el doble, la incertidumbre y la oposición entre el eros y tánatos- son básicas para generar una teoría contemporánea basada en el término.

Por otra parte, Masschelein afirma que el concepto de lo siniestro es relevante en el surgimiento de la cultura post o neo romántica dentro de las artes y la cultura popular. Luego de las revoluciones de los años sesenta y setenta, la atención se centraría en las experiencias íntimas y subjetivas. Después de la crisis económica y política de los años ochenta, esta nueva experiencia de subjetividad se tiñe con una fuerte sensación de extrañamiento, intranquilidad y ansiedad, así como por una conciencia exagerada hacia los cambios que suponía una sociedad capitalista y vertiginosamente globalizada. La amenaza nuclear, la guerra fría, el terrorismo, el nacionalismo, la inmigración, la xenofobia, el individualismo, la omnipresencia de la imagen y el simulacro son algunos de los factores que producen este nuevo sentir. El concepto de lo siniestro hace referencia a estas nuevas preocupaciones, a la estética post romántica y neo gótica, y al clima socio-político de la sociedad occidental post industrial.

No es casualidad que Alexander McQueen comenzara su trabajo como diseñador en los noventa. El cuerpo que en esa época surge es uno angustiado, atribulado y que exhibe los síntomas del trauma de esos momentos (nociones que más adelante explicaré). Los vestidos de McQueen mutaron de la pasarela convencional a una especie de performance y un nuevo tipo de diseñador de modas, mucho más conceptual, emergió. En ese momento, los trabajos de McQueen y de varios modistos más con características similares eran considerados como un estilo de moda que existía en los márgenes de lo tradicional. Así, mientras más extravagantes se volvían las presentaciones de las prendas, los temas se volvían cada vez más oscuros. La ropa y las pasarelas usualmente impregnadas por nociones y sentimientos de muerte, enfermedad y deterioro empezaron a articular a partir de su imaginería ansiedades y placeres particulares de la identidad, al mismo tiempo que nociones de alienación y pérdida procedentes de una situación inestable de rápido cambio social, económico y tecnológico. Este panorama en general de los noventa marcó un cambio en los paradigmas de las sensibilidades. Sostengo que el trabajo de McQueen, más que ser el resultado de una serie vertiginosa de cambio de estilo con lo que hasta el momento era considerado alta costura, es en realidad la consecuencia de una trayectoria histórica y filosófica mucho más amplia. 
La década de los noventa colocó al ser humano al borde entre dos siglos y al filo de la transformación tecnológica. Ese momento histórico requirió que todos aquellos que quisieran participar y ser parte de él, le dieran la espalda al ya avejentado concepto de la era de la modernidad industrial y comenzar a incorporar en su interior la revolución de los medios de comunicación. El trabajo de McQueen se encontraba en esa orilla. Manejaba temas que se ubicaban entre los límites de la belleza y el horror, donde la muerte y el sexo se cruzaban con el comercio. Conceptual y estilísticamente, McQueen diseñó prendas de alta costura que trabajaban con las ansiedades que este cambio de siglo generó y con las especulaciones sobre el cuerpo y la identidad. Creo que este es el momento en el que es posible comenzar a mirar en retrospectiva y colocar el trabajo del diseñador desde una perspectiva nueva.

La globalización y sus consecuencias fueron preocupaciones muy importantes para los artistas y diseñadores del cambio de milenio pues históricamente cargaban pasados muy oscuros como el holocausto, el genocidio, el ascenso del totalitarismo y dos guerras mundiales, así como también el colapso de certezas epistemológicas y el rápido desarrollo de la tecnología dedicada a la información -desde el primer satélite puesto en órbita en 1957, el fin de la antigua Unión Soviética en 1991 y la división ideológica entre el Islam y el Oeste secular. Por ejemplo, en 1995, los diseñadores de la marca Comme des Garçons llevaron a cabo una pasarela, durante el aniversario número quince de la liberación de Auschwitz, en la cual se presentaron dos jóvenes con las cabezas rasuradas y vistiendo trajes a rayas y números impresos. El diseñador belga Martin Margiela, por su parte, desarrolló una pasarela dentro de vagones de trenes la cual fue percibida como una interpretación de aquellos trenes que transportaban judíos a los campos de concentración. Muchos otros de los que estuvieron presentes señalaron que el espectáculo les recordaba el fin del estado soviético. Por otra parte, las fotografías de ropa interior de Steven Meisel para la versión italiana de la revista Vogue fueron fuertemente criticadas por sus connotaciones a aquellas imágenes periodísticas de 1992 que mostraban a los refugiados musulmanes en Bosnia en los campos de detención en Omarska terriblemente desnutridos. Las prendas del diseñador Hussein Chalayan junto con sus presentaciones ostentaban el uso de computadoras tanto en la confección de la ropa como en las animaciones y efectos especiales de sus espectáculos. ${ }^{58}$

${ }^{58}$ Para más ejemplos sobre el trabajo de diseñadores que desarrollaban este tipo de preocupaciones en sus obras consultar: Finkelstein, Joanne. After Fashion. Melbourne University Press, 1996. 
Es en los noventa que lo siniestro se estabiliza y se expande. Esta es la fase que se conoce como la de canonización y diseminación del término. ${ }^{59}$ Lo siniestro es ya reconocido de manera general como un concepto. El ensayo de Freud se encuentra ahora en el centro del canon freudiano y lo siniestro aparece como una palabra clave dentro de estudios especializados. Se da un consenso general entre el origen del término y sus primeros núcleos semánticos. Al mismo tiempo, el término sale de su ámbito dominante -el psicoanálisis, teoría y filosofía post-estructuralista, teoría literaria y sus géneros- hacia otras áreas como la historia del arte, los estudios cinematográficos, la arquitectura, los estudios post-colonialistas, la sociología, la antropología y los estudios sobre religión. Cada nuevo uso del término le añade sustancia conceptual. Además, a finales del siglo $\mathrm{XX}$ y comienzos del siglo XXI, lo siniestro de Freud regresa al dominio del arte donde influye en las artes visuales y en la ficción. Dos publicaciones durante esta época dan cuenta de esto, la primera, la mencioné anteriormente -el libro de Royle- y la segunda es un catalogo publicado por el artista Mike Kelley con apoyo de la galería Tate en Liverpool sobre la exposición curada por artista. ${ }^{60}$ Ambos trabajos están dedicados completamente al concepto de lo siniestro y proveen de material sustancioso sobre el discurso del mismo. El trabajo de Royle se centra predominantemente en la literatura mientras que el de Kelley en las artes visuales.

La formación del concepto ha transgredido las fronteras disciplinares de la que partió. El marco teórico psicoanalítico que ha rodeado a lo siniestro sigue vigente pero es menos predominante pues el concepto se ha diseminado a otras áreas que intentarán responder a nuevas interrogantes. Pero, al mismo tiempo que esto ocurre, la diseminación coincide con una estabilización y una relativa reducción del significado.

La creciente popularidad del término en esta época crea la necesidad de dar información al respecto. Es hasta ahora que lo siniestro se encuentra en otras áreas como teoría de arquitectura, cultura popular y estudios de género. Sin embargo, los esfuerzos más evidentes para establecerlo y darle una clara definición se encuentran en las áreas de literatura, estudios culturales, estéticos y en el arte, en donde el ensayo se incluye como parte de estudio de estas áreas. ¿A qué se debe esta gran movilidad del término? En primer lugar, al ser considerado un no concepto, lo siniestro deambula por muchos lados gracias a su cantidad de substanciación, es decir, que es un tema con tal diversidad de argumentos, ideas importantes y elementos que lo

\footnotetext{
${ }^{59}$ Ibid. Pp. 6

60 Kelley, Mike, The Uncanny by Mike Kelley, Artist. Exh cat. Liverpool, England: Tate Liverpool; Vienna, Austria: Museum Moderner Kunst Stiftung Ludwig Wien, 2004. English and German-English editions. Essays by Mike Kelley, John Welchman and Christoph Grunenberg.
} 
justifican que esto le permite entrar en distintos campos de estudio. El hecho de que lo siniestro no fuera central a la teoría psicoanalítica le dio una doble ventaja: no fue tan criticado por aquellos opositores al del psicoanálisis y por otro lado, pudo ser redescubierto y reapropiado por aquellos interesados en lo marginal y lo olvidado, tal como el deconstructivismo. Bajo la influencia de éste último y del post estructuralismo, la ambigüedad conceptual fue depositada en el centro del termino. Lo siniestro paradójicamente significa el problema mismo de fijar definiciones, de aquellas significaciones inequívocas. Tal como lo afirma la autora Susan Bernstein, lo siniestro es ambulatorio y no puede definírsele por completo. Por estas razones, el ensayo se presta a ser visto desde una gran variedad de perspectivas y se le puede explorar y desarrollar desde distintas disciplinas.

\section{Lo siniestro y otras categorías estéticas}

En el campo de la estética una de las mayores aportaciones fue la relectura del ensayo de Freud por parte de Sarah Kofman, estudiante de Deleuze y Derrida, y sus libros titulados L'enfance de l'art y Quatre romans analytiques que contiene un ensayo titulado, Le Double e(s)t le diable y L'inquiétante étrangeté de L'homme au sable (Der Sandmann). Estos trabajos de Kofman son unos de los pocos estudios dedicados al tema de lo oculto en El hombre de arena- texto literario de donde se desprende el estudio de Freud sobre lo siniestro- y al rol del doble. Desde La infancia del arte Kofman concibe la relación entre héroe y autor en términos del doble. Es decir, como una proyección narcisista del autor motivado por sus deseos inconscientes. Por lo tanto, tanto el héroe como la creación literaria tienen una doble función: una, es la de establecer y fortalecer la identidad del autor como una protección contra la muerte y la otra, mostrar la fragilidad y la fragmentación del sujeto que ya está dividido desde el interior. Kofman lo dice así,

"Los dobles son constitutivos del verdadero ser del artista y su identidad porque lo que hace al duplicarse a sí mismo, al repetirse y representarse, implica una no presencia de sí, una insatisfacción originaria, muerte inmanente en vida, una ausencia de origen simple y total." ${ }^{61}$

Por otra parte, según Kofman, el lector también se identifica con los héroes de las historias en un juego de dobles. Este proceso, añade, se lleva a cabo en un ambiente seguro, en el del arte imitando a la vida y por lo tanto se permite la gratificación de deseos e impulsos reprimidos sin tener que enfrentar ninguna consecuencia. Pero Kofman sabe que el estatus de ficción en todo este proceso no es sólo imaginario. Mientras que el narcisismo secundario explica los procesos de identificación en

\footnotetext{
${ }^{61}$ Kofman, Sarah. L'Enfance de l'art. Payot, Paris. 1970. Pp. 162. (Traducción propia).
} 
términos de proyección e incorporación tanto del escritor como del lector, el narcisismo primario está asociado con creencias primitivas supuestamente superadas como la omnipotencia del pensamiento y la proyección a partir de prácticas mágicas. Por lo tanto, Kofman dice que en tanto duplicidad de experiencias vividas, la narración mimética hace eco del nacimiento y de la muerte y del deambular entre ambos que constituye la vida. Así el arte como el doble de la vida a través de su fantasmática victoria sobre la muerte, revela la relación que hay entre muerte y cultura.

Para finales del siglo $\mathrm{XX}$, algunos de los aspectos más controversiales del trabajo de Freud, tales como su interés en las culturas primitivas, lo oculto y la telepatía son retomados. Hans-Thies Lehmann, investigador teatral alemán, elabora una noción del arte como magia, idea que toma prestada de Tótem y tabú ${ }^{62}$. Lehmann plantea que la idea de la manipulación del artista del mundo ficticio en el ensayo de lo siniestro sitúa al artista en el lugar de mago, lo cual es muy cercano a lo que se entiende sobre lo siniestro en la actualidad en términos de shock. Lehmann añade que a diferencia de lo sublime, las experiencias estéticas de lo siniestro -junto con lo abyecto propuesto por Julia Kristeva- no pueden ser recuperadas a través de un discurso idealista que remonte a las raíces atávicas y primitivas. ${ }^{63}$ Lo que esto quiere decir es que Lehmann ya consideraba a la noción kantiana de lo sublime como lo siniestro, pues ya en ese concepto se experimentaba una desorientación conceptual, una discontinuidad entre el significado y el significante, lo ilimitado, lo informe, lo abstracto y el shock. Es decir, la elaboración teórica y filosófica del concepto de lo sublime en algún momento perdió su efecto de shock, de peligro, ansiedad y muerte, y fue lo siniestro lo que llegó a tratar de recuperar y radicalizar las cualidades perturbadoras de lo sublime sin el segundo movimiento de éste que era la neutralización posterior.

Desde un punto de vista gramatical y semántico, lo siniestro es parte de una serie de conceptos como lo sublime, lo ominoso demoníaco, lo grotesco, lo fantástico, lo gótico, lo extraño, el miedo y con lo abyecto. Todos estos términos son muchas veces utilizados casi como sinónimos. Generalmente, la diseminación de lo siniestro en el

\footnotetext{
62 Desde la perspectiva de lo siniestro, el segundo y tercer capítulo de Tótem y tabú son los más importantes. El segundo ensayo está dedicado a la noción de tabú y a la ambivalencia. Tal como en lo siniestro, en donde también hace énfasis sobre la ambivalencia de la palabra Heimlich, Freud señala que una de las definiciones de la palabra polinesia taboo es unheimlich. Freud concluye en su trabajo, que los demonios son de hecho producidos por la misma fuente que produce el tabú mismo, y es que son las proyecciones de sentimientos hostiles contra la muerte anidadas muy adentro de los sobrevivientes. La idea de proyección es entendida como un sistema primitivo que conlleva el sobre entendido de que los sentimientos negativos inconscientes son manejados como si viniesen del exterior de la persona más que de su interior. Este primer sistema de percepción era dirigido hacia el afuera, es decir, aquello que causa desagrado será tratado como algo extraño y como un objeto adverso y perjudicial que es expulsado.

${ }^{63}$ Esta información puede ser encontrada directamente en el trabajo de Lehmann titulado Das Erhabene ist Das Unheimlich. Sin embargo, yo la retomo del libro de Annelen Masschelein, The unconcept. The Freudian Uncanny in Late Twentieth-Century Theory. Pp. 129.
} 
siglo XX recorre dos ejes: el primero que tiene que ver con la tradición estética postromántica, la cual hace énfasis en la trascendencia, lo sobrenatural, lo oculto y que se encuentra por ejemplo en el trabajo de hace Louis Vax sobre lo siniestro en la literatura fantástica y en la investigación sobre lo grotesco de Wolfang Kayser. E segundo, una línea semántica existencialista post marxista que tiene que ver más con el lado de la alienación, lo extraño y la angustia de lo siniestro y su relación con la sociedad. Este uso indiscriminado del término se debe al declive de la teoría marxista a causa de situaciones políticas como por ejemplo, la caída del muro de Berlín. Sin duda el trabajo de Prawer, fue visionario al elaborar las conexiones entre lo siniestro y lo histórico, económico y psicológico pero la primera aplicación del concepto dentro del contexto de la alienación marxista es a través de la lectura del Manifiesto Comunista de Marx y Engels que propone el crítico e historiador literario Jeffrey Mehlman en Revolución y repetición. Haciendo uso de las nociones de la repetición y lo siniestro, Mehlman trata de revelar aquello que los textos reprimen en sus repeticiones y desplazamientos. Para esto, Mehlman se enfoca en el concepto del espectro en el manifiesto y lo relaciona con lo siniestro de Freud. De alguna forma es una especie de adelanto al trabajo de Derrida de 1993 titulado Espectros de Marx en el cual se redefine la noción de lo siniestro en la era post marxista. ${ }^{64}$

Es durante 1970 y 1980 que el interés sobre lo sublime vuelve y lo siniestro también. Harold Bloom fue una figura clave para esto pues afirmó que Freud era un poeta de lo sublime, y en su libro Agon: Hacia una teoría del revisionismo dice que lo siniestro fue la mayor contribución que el siglo XX le hizo a la estética de lo sublime. Bloom lo plantea de la siguiente manera,

"La contribución de Freud a la estética de lo sublime es la idea de que ésta puede estar basada en la represión. Por lo tanto, lo siniestro puede ser concebido como lo sublime literario o lo sublime negativo y puede ser definido como la manera en la que el poeta a la vez que expresa deseos, pensamientos y emociones previamente reprimidos es capaz de defenderse a sí mismo en contra de su propia imagen creada por medio de rechazarla, una especie de defensa que se basa en no nombrar en lugar de nombrar". ${ }^{5}$

\footnotetext{
${ }^{64}$ En este trabajo, Derrida luego de explorar los debates políticos contemporáneos sobre la caída del muro de Berlín, el apartheid en Sudáfrica y la afirmación de Fukuyama que celebra el fin de la historia, vuelve a lo propuesto por Marx, Feuerbach, Platón, Heidegger y Freud para guiarse en un emprendimiento deconstructivo en donde lo siniestro es usado como un concepto desestabilizador que socaba y perturba el orden político y ético. En este sentido, y sin ahondar demasiado en ello, Derrida propone una especie de fantología ${ }^{64}$ y ontología de lo fantasmal en la cual lo reprimido regresa, lo espectral toma primacía sobre la existencia. Esta nueva filosofía pretende examinar el estado intermedio o suspendido de un fantasma y de la ficción -algo que no está ni vivo ni muerto, ni aquí ni allá- como el ejemplo básico de la omnipresencia de lo inmaterial, lo virtual y lo innombrable en la sociedad. Por lo tanto, concluye que el espectro propuesto por Marx persigue al presente y a sus instituciones y aún más cuando el marxismo es declarado muerto por el capitalismo.

${ }^{65}$ Bloom, Harold. Freud and the Poetic Sublime. A Catastrophe Theory of the Sublime. Prentice Hall, New York, 1981. Pp. 108. (Traducción propia).
} 
La noción que Bloom plantea sobre lo siniestro y lo negativo sublime se obtiene por medio de la negación de un predecesor, es decir, que todo gran poeta debe enfrascarse en una lucha consciente o inconsciente con un predecesor idealizado. ${ }^{66}$

Otro concepto cercano a lo siniestro es lo abyecto, elaborado por Julia Kristeva en su libro titulado Poderes del horror. Sobre la abyección. La autora claramente diferencia lo abyecto de lo siniestro, puesto que el primero es una sensación mucho más violenta y no tiene que ver con el reconocimiento de algo familiar pero sí se retrotrae a las primeras etapas del desarrollo humano. De esta forma, lo abyecto se ha unido a lo siniestro debido a varias razones. Al igual que en el ensayo de Freud, Kristeva en su trabajo combinó perspectivas psicoanalíticas, antropológicas y estéticas. Además, con lo abyecto Kristeva intentó explicar un fenómeno parecido a lo siniestro, en cuanto a que se plantea la pregunta de cómo algo que en la realidad es tomado como desagradable en el arte puede ser atractivo. Por otra parte, igual que lo siniestro, lo abyecto está relacionado con la ausencia (o con aquello que aún no está presente) de límites entre el objeto y el sujeto. También, lo abyecto no puede ser controlado completamente y aunque inspire horror y desagrado, igual que lo siniestro, continúa ejerciendo fascinación.

Lo siniestro está relacionado con lo abyecto en el campo de los estudios de la estética para poder darle una explicación a todas aquellas categorías que causan horror y desamparo. Sin embargo, en cualquier explicación que se dé, siempre se trata de enfatizar las raíces primitivas y atávicas de lo siniestro para subrayar el hecho de que siempre ha sido una parte natural e indispensable de la cultura ${ }^{67}$ La noción de lo abyecto propuesto por Kristeva se acerca mucho a lo que proponía Kayser sobre lo grotesco y a la categoría de lo monstruoso. Es interesante notar que muchas de este tipo de categorías han sido incluidas bajo la categoría de lo fantástico. Por ejemplo, en los noventa, lo siniestro de Freud es incorporado en los estudios de lo fantástico como

\footnotetext{
${ }^{66}$ Los autores deben reconciliarse con la grandeza de sus modelos a seguir y reprimir este sentimiento si es que aspiran a lograr algo original por sí mismos. Bloom afirma que esto puede lograrse a través de varios conductos, pero el que tiene que ver con lo siniestro sólo se logra a través de la repetición y la discontinuidad o el impulso inconsciente de repetir el ejemplo. Esta noción postromántica de Bloom y su concepto de angustia por influencia fue aplicado a Freud y sus luchas internas con Jentsch, Hoffmann, y Adler. Por lo tanto, Bloom y sus seguidores ubican lo siniestro en el autor.

${ }^{67}$ En lo siniestro, tanto la proyección como la omnipotencia del pensamiento son parte fundamental de la primera concepción que se tenía del mundo, es decir, el animismo. Así que cualquier cosa que le recuerde al hombre moderno sobre esta etapa supuestamente superada se experimenta como siniestro. De esta forma, tanto los seres vivos (seres humanos, animales y plantas) como los objetos inanimados son dotados de espíritu o alma. Uno de los aspectos más extremos de este mecanismo es el doble, el cual es una proyección del ser que se ha vuelto autónoma. Confrontado con la inexorabilidad de la muerte, el hombre primitivo resolvió el dilema por medio de la discriminación entre el mundo interno de sus pensamientos, el alma inmortal y su envase, el cuerpo, los cuales están encarnados en el doble.
} 
parte de una forma más subversiva. Rosemary Jackson es su texto sobre literatura fantástica afirma que,

"La fantasía en la literatura trata de manera directa y en repetidas ocasiones con el material inconsciente y por lo tanto resulta algo absurdo tratar de comprender su significado sin tener alguna referencia a textos psicoanalíticos. ${ }^{\prime 68}$

Esta autora desarrolla un marco de trabajo de lo fantástico más como modelo que como género, es decir, ella examina la relación entre la literatura, la realidad y la imaginación, además hace distinción entre la fantasía como escape o el arte como compensación y la fantasía subversiva o el arte como alienación. Esta última entraña una posibilidad más atractiva pues promete una alteración lingüística más radical del sujeto y de la sociedad. Lo siniestro, entonces, con sus raíces en el animismo por un lado, y su relación con lo reprimido por el otro, otorga el punto de partida para esta idea.

"Introducir lo fantástico es remplazar lo familiar, el confort, lo unheimlich con lo alienado, la intranquilidad, lo siniestro. Es introducir áreas oscura de algo completamente ajeno e invisible, es decir, aquel espacio fuera de los límites de lo humano y lo real, lo que está fuera del control del mundo y de la mirada."

Por otra parte, también existe la conexión entre lo fantástico y lo espectacular en la cultura, situando a lo siniestro en la transición histórica de la llustración al Romanticismo. ${ }^{70}$ Estos modelos de análisis histórico se elaboran en estudios de género, literatura, cine y artes visuales. En las últimas décadas, lo siniestro ha cobrado importancia en las artes y la teoría al examinar algunos elementos que lo conforman como lo espectral y el doble. Además, la aplicación de lo siniestro tiene su aparición en el cuerpo social, cultural y estético del siglo XVIII en la tensión que se da entre el racionalismo y lo irracional.

En la cultura del siglo $\mathrm{XX}$ y especialmente en el movimiento modernista y surrealista, lo siniestro se vuelve más central dentro de las prácticas estéticas y teóricas. Hal Foster dice,

"Si hay un concepto que comprenda al surrealismo éste debe ser contemporáneo al movimiento e inmanente a su campo; y es en parte la historicidad de este concepto lo que me interesa aquí. Creo que este concepto es el de lo siniestro, es decir, aquel que se preocupa con los eventos en los cuales el material reprimido retorna de maneras en las que se afectan las identidades unitarias, las normas estéticas y el orden social. En mi argumentación, los surrealista no solo se ven atraídos hacia el retorno de lo reprimido sino que también buscan re dirigir este regreso hacia fines críticos. Por lo tanto, debo afirmar que lo siniestro es crucial para

\footnotetext{
68 Jackson, Rosemary. Fantasy: the Literature of the Subversion. Methuen. London, 1981. Pp.6. (Traducción propia).

69 lbid. Pp. 43. (Traducción propia).

${ }^{70}$ Aquellos autores que examinan este punto de vista son Lyotard, Castle, Von der Thüsen y Park, entre otros.
} 
ciertas obras surrealistas en particular así como a nociones generales del movimiento (por ejemplo, lo maravilloso, la belleza compulsiva). En este sentido, el concepto de lo siniestro no

es meramente contemporáneo del surrealismo sino que tiene que ver con muchas de sus actividades." ${ }^{71}$

Este nuevo camino da como resultado una construcción conceptual de lo siniestro diferente en donde lo no familiar es entendido a un nivel más existencial y político que sobrenatural.

En los noventa, la teoría del trauma cobró fama sobre todo en Estados Unidos. Los estudios sobre el trauma son una mezcla entre la deconstrucción y el psicoanálisis, en especial sobre los trabajos de la segunda fase del trabajo de Freud y en específico de Más allá del principio del placer, en donde las experiencias de neurosis traumáticas después de la Primera Guerra Mundial llevaron a Freud al desarrollo de la hipótesis de los impulsos de muerte. El ensayo de lo siniestro es una constante referencia en la teoría del trauma pues ofrece una forma válida de enfrentarse al trauma en términos del shock, del evento y la repetición en lugar de en términos de la representación narrativa.

Los trabajos de Kristeva y las constantes aplicaciones de lo siniestro en la antropología, la religión y los estudios referentes al trauma ayudan a que el potencial del concepto freudiano se expanda a nuevos ámbitos que mantienen siempre una fuerte conexión con el ensayo original.

Los problemas sociales como la xenofobia, la inmigración, el exilio y el trauma generan un tipo de ansiedad nunca antes visto y que está relacionado con la oposición de lo familiar y lo extranjero, con las cada vez más borrosas delimitaciones fronterizas que causan amenaza. Lo siniestro se redefine pero no se desconecta de las prácticas artísticas y culturales y como fenómeno estético captura el estado de ánimo del siglo que termina y el que comienza. En literatura se le empieza a relacionar con Murakami y Paul Auster; en las artes visuales con Cindy Sherman, Sophie Calle o Lucian Freud; en el cine con David Lynch; Cronenberg, en la arquitectura con Libeskind, Tschumi y Eisenman.

Lo siniestro es el concepto de un afecto y para finales del milenio su recorrido lo coloca como herramienta teórica y como inspiración para la creación artística. El concepto de lo siniestro se introduce en el arte contemporáneo y en la cultura popular por vías de la teoría. En las universidades se le estudia a través de nuevas tendencias

${ }^{71}$ Foster, Hal. Compulsive Beauty. MIT Press, 1993. Pp. 23. 
culturales como el New wave, el gótico y el ciberpunk. Lo siniestro inspira y une nuevas forma de producción artística. Uno de los elementos recurrentes de la presencia de lo siniestro en las artes visuales es la importancia de la figura humana. Ya sea a través de la presencia de muñecas, esculturas de cera, gigantes, robots, partes de cuerpos, cadáveres y la moda- como intentaré demostrar a partir del trabajo de Alexander McQueen- lo humano y post-humano es donde lo siniestro es depositado.

Las muñecas, los autómatas (que vienen desde el siglo XVIII), las prótesis, cráneos, monstruos, los cyborgs o seres humanos tecnológicamente mejorados, las cirugías pláticas, los implantes de órganos, los transexuales, la distorsión, la fragmentación y muchas cosas más del estilo están relacionadas con lo siniestro. De esta manera, en una primera instancia, la estructura rizomática de lo siniestro pareció estabilizarlo al principio del siglo XXI pero muchas aplicaciones del mismo continúan apareciendo. La más reciente, como dato curioso, viene del campo de la robótica y la neurociencia. Lo siniestro se instaló en estas áreas a partir de la traducción al inglés del texto del japonés Masahiro Mori titulado El valle inquietante. Mori, un científico de robots, afirma que éstos, como seres inanimados se vuelven más reales y familiares cuando se les dan rasgos parecidos a los de los humanos, pero sólo hasta cierto punto. Cuando se vuelven muy parecidos, esa familiaridad se torna perturbadora y causa miedo y más aún cuando se les añade movimiento. Este fenómeno lo representa Mori en un diagrama que es llamado el valle inquietante en el cual se representa por medio de gráficas las relaciones entre familiaridad y agrado. En esta representación, Morí coloca al cadáver, al zombie y a la mano prostética muy por debajo de la zona de confort porque según su teoría el valle inquietante es causado por el miedo a la muerte.

El texto de Mori se parece en algunos aspectos al de Freud. El valle inquietante puede aplicarse a la muñeca llamada Olimpia en el cuento El Hombre de arena de Hoffmann cuya perfección mecánica era siniestra para todos, excepto para Nathaniel. Pero el objetivo del trabajo del japonés es completamente diferente al de Freud, a Mori le interesa sobre todo como evitar el valle y no tanto conocer la razón por la que ocurre. ${ }^{72}$

Pero dejando esto de lado por el momento, se puede ver que el concepto de lo siniestro atraviesa una gran variedad de áreas de conocimiento y estudio. Sin lugar a

\footnotetext{
${ }^{72}$ La hipótesis del valle inquietante ha sido muy importante para el campo de la robótica y la animación, en donde se utiliza como una especie de guía de los estándares que se deben evitar en el desarrollo de la nueva tecnología y el diseño. Los robots y las figuras animadas deben parecerse a los seres humanos pero no demasiado porque pueden producir rechazo. Los aspectos que pueden producir este fenómeno son las expresiones faciales, los movimientos de los ojos, la personalidad, etc.
} 
dudas lo encontramos en el arte y en muchas formas de sus producciones. Lo que intentaré responder es, si a partir de todo lo recorrido hasta ahora en este trabajo, se puede encontrar en la moda. Si el concepto de lo siniestro es posible que se manifieste en las artes visuales a través del cuerpo, ¿qué mejor campo de acción para analizar su presencia y sus consecuencias que la moda? ¿Por qué resulta placentero el sentimiento de lo siniestro? ¿Por qué si se habla de elementos que deberían ser reprimidos por nuestra propia seguridad psíquica, lo siniestro debe de evocarlos para mantenernos a salvo y al hacerlo provocar una experiencia de deleite? Según lo que se ha expuesto hasta ahora, una de las respuestas podría ser debido a que lo siniestro renueva la integración de tendencias disociadas, como el amor y el odio. Pero parece que su incursión en la estética se debe a otros factores también.

Un análisis sobre el trabajo de Alexander McQueen intentará contestar estas preguntas. 


\section{Alexander McQueen, heraldo de lo siniestro}

En septiembre de 1998, Alexander McQueen fue invitado a editar un número de la revista Dazed and Confused. En esta edición hubo una serie de fotografías tomadas por Nick Knight. La serie se tituló Access-Able y en ellas se podían ver el resultado del trabajo entre modelos discapacitadas y algunos diseñadores de moda. La editorial de la revista decía que el objetivo del proyecto era el de desafiar las preconcepciones de lo que es considerado hermoso. Estas imágenes mostraban una especie de identificación doble evitando cualquier tipo de noción de unidad en el sujeto. Las modelos tiene discapacidades físicas pero éstas no son evidentes en la fotografías, como si tratasen de ser colocadas en segundo plano.

La fotografía de portada de la revista es de la atleta Aimee Mullins, vestida solamente con pantalones de ejercicio y usando un par de prótesis metálicas debido a que tiene amputadas las dos piernas (Placa 9). En otra imagen, se le puede ver vestida con una crinolina, y otros accesorios diseñados por Alexander McQueen usando piernas prostéticas (Placas 10).

Ambas fotografías establecen los términos de referencia de la serie. Mullins es al mismo tiempo la mujer atlética de cuerpo hermoso y la inválida. Su torso desnudo se contrapone a esos siniestros aparatos que tiene en lugar de piernas. La fotografía juega con la provocación entre el mito del cuerpo unificado y sugiere la posibilidad de una experiencia corporal múltiple y de otro orden. En la segunda imagen, vestida como una muñeca y con una expresión casi de maniquí también se problematiza y desafía la integridad corporal. Sus piernas y la discontinuidad entre una realidad de carne y hueso y las prótesis de fibra de vidrio presentes, hacen evidente que el proceso de transferencia entre el espectador y la imagen, y entre la mujer y el maniquí, nunca está completo, provocando así el afecto de lo siniestro.

La aparición de ese "otro" que habla de lo que de otra forma no se hablaría es importantísimo para la creación del sentimiento de lo siniestro. ${ }^{73}$ Es posible decir que los elementos presentes en la imagen operan como un tipo de herramienta conceptual, es decir, como mecanismos simbólicos a través de los cuales los

\footnotetext{
${ }^{73} \mathrm{Si}$, como ya se sabe, unheimlich es la negación de heimlich en el sentido de ser familiar, hogareña pero que también tiene un segundo significado que es escondido o furtivo entonces desde un punto de vista psicoanalítico esta ambivalencia no es extraordinaria. El prefijo un no es solamente una negación lingüística sino también el símbolo de la represión. Esto quiere decir que lo siniestro está marcado por el inconsciente que no conoce la negación o la contradicción. Aun cuando algo es negado esto sigue estando presente en el inconsciente. Así, partiendo de esta línea de razonamiento, la contradicción que resulta de la negación no es exclusiva o binaria. Es decir, negar algo lo evoca al mismo tiempo.
} 
contenidos reprimidos encontraron representación. Las narrativas que resultan de estos conceptos comienzan a dar forma a la gramática de lo siniestro dentro del trabajo creativo de McQueen. Además, al presentar a una mujer con prendas de diseñador y cuyas piernas terminan en prótesis, lo que se está creando es la erotización de lo inanimado. Todos estos elementos simbolizaban de una u otra manera el surgimiento de fuerzas que se mantienen bien sujetas dentro del inconsciente de las personas y que al presentarse abiertamente hacen que resurjan al presente.

El proceso de identificación de estas imágenes encierra al espectador en un diálogo perpetuo. Este constante dinamismo, este movimiento psíquico que se da es de hecho el paradigma visual de la experiencia de lo siniestro. Las imágenes, como una pequeña muestra de lo que es el trabajo de McQueen, presentan la continuidad y discontinuidad necesaria para el concepto freudiano. El simbolismo corporal que oscila entre la unidad ilusoria y el ser fragmentado es el campo perfecto de presencia para lo siniestro. Algo en estas fotografías está oculto detrás del espacio visual y nunca se sabe con certeza qué es. Todo lo que se puede ver es el acto mismo de ocultamiento.

Aun cuando en muchas ocasiones el trabajo de los artistas es el de especular sobre las cuestiones de identidad y comunidad en el mundo, éste no era el caso en los diseñadores de moda. A pesar de esto, en una época como los noventa donde las ideas y conceptos sobre el ser humano son inestables, o cambiantes, la moda de McQueen fue capaz de colocarse en el centro y jugar un papel trascendental en la construcción de imágenes y significados, al mismo tiempo que creaba nuevas ansiedades e ideales.

En 1999, J.G. Baillard escribió para la publicación Statesman un texto titulado Diary. En él miraba en retrospectiva hacia el siglo XX y comentaba,

"Tengo la sospecha de que dentro de algunos años habrá un rechazo generalizado hacia el siglo XX, sus horrores y sus corrupciones. A pesar de sus grandes avances en ciencia y tecnología, será visto como una época barbárica. Mis nietos son todos menores de cuatro años de edad; serán la primera generación que no tendrá memorias sobre este siglo y seguramente estarán horrorizados cuando sepan lo que se permitió que ocurriera. Para ellos, nuestro devaluado entretenimiento cultural y nuestro hedonismo de "todo incluido" será inextricablemente ligado a Auschwitz y a Hiroshima, aunque nosotros nunca hagamos la conexión." 74

Es precisamente esa conexión la que se articula de manera brillante y consciente en la ropa de McQueen en donde se sugiere que el cuerpo es el territorio de la perfección y

\footnotetext{
${ }^{74}$ Ballard, J.G. Diary. New Statesmen. Dic. 1999-Enero 2000. Pp.9. (Traducción propia).
} 
de la descomposición al mismo tiempo, creando una fascinación ante el horror y la belleza. Estas intersecciones fueron articuladas en sus prendas por medio de referencias históricas. A pesar del hecho de que la moda es un campo dedicado a la novedad, inclusive se podría decir que fetichiza lo novedoso, fueron precisamente estas características de retomar lo pasado lo que invadía constantemente la obra de McQueen. Es decir, para este diseñador lo más moderno era aquello que se doblaba sobre sí mismo como lo más antiguo. Como lo plantea de mejor manera aunque en diferente contexto la profesora en Historia del arte de la Universidad de Londres y escritora inglesa Lynda Nead,

"El pasado regresó a perturbar e inquietar la confianza de lo moderno."75

¿No es acaso esto lo siniestro? Nead desarrolla la idea de la modernidad conectada de forma vital y en constante diálogo con sus propias condiciones históricas de existencia, de tal manera que lo moderno nunca puede representar un corte total con el pasado. En cambio, la modernidad puede ser entendida como una serie de discursos y procesos históricos que están profunda y necesariamente enraizadas con la construcción del pasado. Por lo tanto, la moda aunque sea considerada un paradigma de lo novedoso, está de hecho atada por las mismas condiciones históricas que la producen y esto es claro en el trabajo de McQueen.

En la colección otoño/invierno 1998 (Placa 11), el diseñador sugiere el dialogo entre el presente y el pasado con una colección dedicada a Juana de Arco. El vestido color rojo trae consigo la historia de la sangre, del fuego y del martirio de esa figura femenina. Además de la fuerza visual de la presentación en donde la modelo se colocó dentro de un círculo de fuego, el vestido contempla que el rostro sea cubierto por completo para que ya no sea posible ver a una persona sino solamente al símbolo de la historia recreada. Nead utiliza para describir el juego del tiempo con una metáfora particularmente interesante. Dice que el tiempo histórico se dobla en sí mismo una y otra vez como un pañuelo de tela arrugado. Al igual que el vestido de McQueen, con sus delicados pliegues y tiras que se sobreponen una sobre otra al compás de los pasos de quien lo usa, el tiempo se junta y pliega sobre sí mismo una y otra vez. Distintos puntos o momentos históricos se superponen logrando el retorno de aquello que parece olvidado y que sin embargo al momento de surgir provoca en el espectador que recuerde aquello que parecía perdido. El resurgir de una figura femenina, un arquetipo, es lo que despierta el sentimiento de lo siniestro pues se pensaba abandonado en algún instante del tiempo. Las llamas del círculo y el juego de

${ }^{75}$ Nead, Lynda. Victorian Babylon: People, Streets and Images in Nineteenth-Century London. Yale University Press. New Haven y Londres, 2000. Pp.8. 
las tiras sobre las piernas logran conectar periodos de tiempo debido a su proximidad, uniendo el pasado, el presente y el futuro en constantes e inesperadas relaciones. El vestido es en este sentido el producto de una multiplicidad de eras.

Esta reutilización de personajes y temas históricos dominó el trabajo de McQueen. En 1930 Walter Benjamin escribió que,

"La verdadera imagen del pasado pasa súbitamente. Sólo en la imagen, que relampaguea de una vez para siempre en el instante de su cognoscibilidad se deja fijar el pasado. (...) Puesto que es una imagen irrevocable del pasado, que corre el riesgo de desvanecerse para cada presente que no se reconozca en ella." ${ }^{, 76}$

De esta manera, la moda de McQueen que se produjo con más fuerza fue en la década de los noventa, produciendo un trabajo que sentaba sus bases en lo que Benjamin sostenía y a partir de la elección del diseñador de articular un imaginario histórico con intereses contemporáneos. La metáfora de Benjamin sobre el tiempo como un laberinto que nuevamente se dobla sobre sí mismo da una pauta más para comprender el trabajo de McQueen. Y es en este constante devenir del tiempo en sus trabajos que sigilosamente comienza a reptar el sentimiento de lo siniestro. En cada esquina donde el tiempo se dobla y retorna, pareciera ser que algo que ya fue reprimido a lo largo del tiempo vuelve para incitar una sensación intensa y a veces perturbadora.

Se ha dicho varias veces que Freud produjo una gran cantidad de imágenes y temas para intentar definir lo siniestro. Si bien esto es cierto, la naturaleza del concepto es en esencia el retorno de lo reprimido. Lo que sucede es la súbita revelación de una huella remota en la memoria, es decir, no el recuerdo de la cosa misma que ha sido reprimida, sino el rastro o huella de su movimiento en el inconsciente. Estas cosasrepresentaciones no son las representaciones exactas de las cosas, sería más apropiado definirlas como los fantasmas de las cosas. Debido a que la conexión con la percepción que surge en el presente no se da de manera muy clara, el sistema preconsciente falla al intentar ligarse con una palabra de representación y lo reprimido no puede nunca volverse completamente consciente ni reprimirse totalmente otra vez. Como resultado, el afecto que estaba separado del contenido en el proceso de represión se descarga en una forma sutil de ansiedad. Esto es lo siniestro y en este sentido, y de acuerdo con Freud, tiene que ver más con la experiencia del proceso de represión y su retorno que con el contenido reprimido en sí. La ropa de McQueen es

\footnotetext{
${ }^{76}$ Benjamin, Walter. Tesis de filosofía de la historia. Ed. Angelus Novus. Barcelona, 1971. Pp. 79.
} 
tan atractiva porque los fantasmas ahí presentes son nuestros propios fantasmas que representan las proyecciones sintomáticas de la psique de la vida contemporánea.

Así en este constante ir y venir del pasado y del presente uno de los elementos más utilizados por el diseñador es el corset. Desde aquellos que aludían al concepto de la femme fatale hasta los que parecían ortopédicos; desde los románticos y nostálgicos hasta aquellos perversos e inquietantes, sus reinterpretaciones del histórico corset evocan la presencia de algo perturbador a partir de la idea que se tiene del cuerpo femenino. Estos ceñidores hablan de una mujer que no es aquella a la que se está acostumbrado. Es una nueva imagen femenina oscuramente perturbadora. Lo femenino que retorna con una presencia siniestra pues no es la imagen de la mujermadre que cuida y arropa sino de aquella que castra a todo aquel que se le acerca. Es esta mujer encorsetada que vuelve de lo reprimido para recordarle al espectador aquellos miedos y deseos primordiales relacionados con el cuerpo de la mujer. (Placas $12,12 \mathrm{a}$ y 12b) Estos apropiamientos en la obra de McQueen constituyen una serie de instancias que demuestran el uso de la historia en el presente, del retorno de rutas que se retuercen sobre sí mismas dentro del laberinto benjaminiano metáfora que corporizó a través de la imagen del flâneur y la prostituta.

Yo añadiría a estos dos últimos personajes el de la calavera, motivo principal y recurrente dentro de toda la producción de McQueen y para decir esto, me baso en lo postulado en 1984 por Frederic Jameson, crítico literario estadounidense, quien dijo que la historia estaba siendo saqueada por la cultura visual contemporánea para crear un carnaval post-moderno y que el incesante retorno del pasado era en sí mismo una especie de reciclamiento cadavérico de la historia. ${ }^{77}$ No resulta pues extraño que el motivo principal de McQueen sea la calavera, pues no era ajeno a este tipo de razonamientos al momento de crear sus prendas.

Podría decirse, que McQueen presentaba en todas sus colecciones un hábito casi neurótico de la cita histórica. Desde su propio pasado como en la colección titulada The Girl Who Lived in a Tree (Placa 13) en la que se narra la fantasía del diseñador acerca de una niña que imaginaba vivía en el olmo de su casa- cuando era niño hasta la colección Highland Rape en la que hace un grito de protesta ante los saqueos y violaciones que ha sufrido Escocia por parte de Inglaterra a lo largo de la historia (Placa 14 y 14a). Entre más se ve la vuelta del pasado al presente en la prendas, más se vislumbra la presencia de lo siniestro en ellas y sus consecuencias pues este

77 Jameson, Frederic. El Posmodernismo o la lógica cultural del capitalismo avanzado. Ed. Paidós. Buenos Aires, 1991. 
retorno no es resplandeciente o pintoresco sino oscuro y lleno de referencias a miedos y fantasmas reprimidos y que a modo de defensa el diseñador las presenta en creaciones de alta costura. No es raro que McQueen hable de violación al referirse a los levantamientos Jacobitas ${ }^{78}$ del siglo XVIII y la expulsión de las Tierras Altas en Escocia que terminaron con un enorme genocidio pues para él, el regreso del pasado sobre el tiempo del presente no es uno de esplendor, sino uno que revela nuevamente aquellas cosas que parecían estar fuertemente suprimidas. El utilizar el término de violación no hace más que hincapié en el aspecto violento de aquello que regresó al presente. Así, las prendas de tal colección presentan rasgaduras y tirones, o solamente presentan a la modelo con una delicada y transparente ropa interior. Se puede decir que las modelos vestidas con ropa de McQueen, son las Olimpias de Hoffman en una historia de horror sin vida y ultrajadas pero representando un pasado vivo no olvidado. De esta manera, el presente se torna siniestro con tales articulaciones conceptuales. Sus Olimpias son cuerpos lujosamente andrajosos y ultrajados que vienen del pasado para recordar la historia de Escocia, patria de sus ancestros.

De esta forma, el imaginario histórico de algunas de las prendas de McQueen se conjuga con lo siniestro y el trauma en el momento del retorno de lo pasado. Además, el producto de representar al presente como historia tiene el efecto de transformar el aquí y el ahora en algo no familiar y extraño. Justo eso pasa con estas ropas y el concepto de lo siniestro: el presente que muestran está empapado de historia distanciando al espectador del presente y produciéndole un sentimiento incomodo, tétrico y que retorna de la historia que se creía suprimida. ${ }^{79}$

\section{El arte de vestir fantasmas}

El retorno de lo reprimido en lo siniestro es evocado por algo que pertenece a la realidad. Lo siniestro siempre augura el retorno de lo reprimido como un peligro

\footnotetext{
${ }^{78}$ Los levantamientos jacobitas fueron una serie de rebeliones en las islas británicas entre 1688 y 1746 e intentaba conseguir la restauración en los tronos de Inglaterra y Escocia a los miembros de la Casa de Estuardo. Este movimiento tuvo como consecuencia la emigración masiva de los de los pueblos escoceses.

${ }^{79}$ Este es el paso intermedio entre el auto-erotismo y el amor por el objeto y es cuando el ego en sí mismo se ve profundamente ungido por la libido. Diferentes etapas le siguen a ésta pero no sin dejar rastro, es decir, el advenimiento de una nueva no quiere decir que la pasada haya desaparecido completamente. La omnipotencia del pensamiento, también llamada narcicismo intelectual, es la base de todo desarrollo social. Cada vez que las construcciones intelectuales se vuelven más y más sofisticadas, el hombre tiene que renunciar a la satisfacción erótica directa que se le otorga a la sobre valoración del poder de sus pensamientos y al mecanismo de proyección. Cf. con Freud, Sigmund. La interpretación de los sueños. Madrid, Biblioteca Nueva, 1972; Dinámica de la transferencia. Obras completas. Amorrortu Editores. Buenos Aires, 1991; Tótem y tabú. Obras completas. Amorrortu Editores. Buenos Aires, 1991; El tabú de la virginidad. Obras completas. Amorrortu Editores. Buenos Aires, 1991; Más allá del principio del placer. Obras completas. Amorrortu Editores. Buenos Aires, 1991.
} 
menor, tal vez no del todo identificado debido a que el impulso reprimido se mantiene aún en el inconsciente. En este sentido, lo siniestro podría entenderse como un mecanismo de defensa ante la ansiedad, provocando solamente una leve perturbación. Esta interpretación de lo siniestro como protección ante la ansiedad hace que se pueda conectar con el arte. Lo siniestro puede ser placentero en el arte pues anticipa el peligro así como la satisfacción de impulsos prohibidos provenientes de fuentes inconscientes más profundas. Así, acompañado y facilitado por los placeres que sobrevienen del arte, el resultado de lo siniestro es una mezcla entre miedo y deleite. De esta manera, se sugiere que Freud considera a lo siniestro como un fenómeno estético más que como uno clínico. ${ }^{80}$ Freud dice,

"Parece que en el curso de nuestro desarrollo individual todos hemos pasado por una fase correspondiente a este animismo de los primitivos, que en ninguno de nosotros esa fase ha transcurrido sin dejar restos y trazas capaces de manifestarse en cualquier momento; y es como si todo cuanto hoy nos parece siniestro cumpliera la condición de tocar estos restos de actividad animista e incitar su exteriorización.,81

¿A qué se debe que los diseños de McQueen aparezcan ante el espectador de forma tan perturbadora pero al mismo tiempo atractivos? Desde la perspectiva de mi planteamiento, me parece que la unión de estas dicotomías se da como resultado de la presencia de lo siniestro, a partir de la articulación de los miedos que perseguían a la sociedad de los noventa. En esa época, existían dos tipos de diseñadores: aquellos que utilizaban las prendas para otorgar un tipo de consuelo ante las grandes preocupaciones y los otros, como McQueen que buscaban revelar los miedos y angustias en una especie de terapia de shock generada a partir de imágenes en ocasiones opuestas pero sin duda dialécticas.

La teoría de las imágenes dialécticas de Benjamin no está basada en una simple comparación sino más bien en una retransmisión histórica más compleja entre el pasado y el presente. Benjamin lo dice así,

"No es que el pasado arroje luz sobre lo presente, o lo presente sobre lo pasado, sino que imagen es aquello en donde lo que ha sido se une como un relámpago al ahora en una constelación. En otras palabras: imagen es la dialéctica en reposo. Pero mientras que la relación del presente con el pasado es puramente temporal, continua, la de lo que ha sido con el ahora es dialéctica: no es discurrir, sino una imagen, en discontinuidad. Sólo las imágenes dialécticas son auténticas imágenes (esto es no arcaicas) y el lugar donde se las encuentra es el lenguaje.,82

\footnotetext{
${ }^{80}$ El ensayo de lo siniestro es interesante en este aspecto pues genera preguntas que lo sitúan en un ámbito teórico más amplio. Freud mismo se preguntó cómo puede la literatura o el arte evocar sentimientos tan distintos a aquellos que siempre se han visto favorecidos por la estética, sentimientos como lo siniestro, el miedo, el horror y el desagrado.

${ }^{81}$ Freud, Sigmund. Lo siniestro. Obras completas. Amorrortu Editores. Buenos Aire,1991. Pp. 10.

82 Bejamin, Walter. Libro de los pasajes. Akal. Madrid, 2005. Pp. 465.
} 
Para Benjamin esta relación entre imágenes funcionaba como la técnica del montaje en el cine. El principio de este proceso es que al yuxtaponer dos imágenes una tercera con otro significado es creada. Benjamin entendió esta relación como una dialéctica de imágenes en donde los motivos del pasado y el presente funcionaban como tesis y antítesis. Es ese reconocimiento mutuo entre las imágenes del pasado y las del presente lo que crea una imagen dialéctica que transforma a ambas. Esto es justamente lo que McQueen logra con sus prendas que combinan elementos narrativos del pasado: el resultado es una nueva imagen llena de significado nuevo sin olvidar lo anterior. Pero lo más interesante aún falta. Benjamin sabía que al ser impactada fuera del contexto del pasado, la imagen dialéctica podía ser leída en el presente como verdadera pero también sabía que no lo era del todo sino que era una certidumbre fugaz y temporal, existente sólo en el momento de la percepción caracterizado por el shock. ${ }^{83}$ Es decir, no es solamente que el pasado iluminara el presente o viceversa, sino que las dos imágenes al unirse trazaban una conexión previamente escondida. Este es para mi entender, otro de los fundamentos del proceso de la aparición de lo siniestro en las ropas de McQueen. A través de las evocaciones de pasado de sus prendas, éstas parecían estar siendo usadas por fantasmas errantes, inquietos y evanescentes de otra época.

Esta fantasmatización podría situarse en el siglo XVIII. En la novela de Ann Radcliffe titulada Los misterios de Udolfo se comienza con esa nueva concepción de la realidad como la existencia de dos esferas ontológicas distintivas: una, extraordinaria, irracional, irruptora y casi siempre seductora, y la otra, ordinaria, doméstica y en la mayoría de las ocasiones poco interesante. El texto está plagado de presencias fantasmales, aunque no de aquellos fantasmas de las creencias populares, sino de unos de naturaleza más subjetiva, delicada y de origen emocional. Las escenas descritas están plagadas de espectros, dándose un fenómeno que se conoce como sobrenaturalización de la vida diaria, ${ }^{84}$ en donde los fantasmas de los que se habla en la ficción, desaparecen y un nuevo tipo de aparición emerge. Terry Castle, autora de El termómetro femenino dice con respecto a esta novela,

"Estar embrujada, de acuerdo con el mito de la novela romántica, es desplegar los poderes propios de una imaginación empática; los crueles y los insensibles no tienen ese tipo de alucinaciones. Aquellos que aman, están por definición, abiertos al espíritu del otro". ${ }^{85}$

\footnotetext{
${ }^{83}$ Benjamin Walter. Sobre algunos temas en Baudelaire. Ed. El Aleph.com. 1999.

${ }^{84}$ Castle, Terry. The Female Thermometer. Eighteenth-Century Culture and the Invention of the Uncanny. Oxford University Press. New York. 1995. Pp. 122.

85 Ibid. Pp. 122. (Traduccion propia).
} 
Lo sobrenatural en Radcliffe ha sido desplazado y desviado hacia el ámbito de lo cotidiano. A pesar de que el mundo de los fantasmas pierde su fuerza, el mundo de lo ordinario y real está siendo metafóricamente cubierto por un nuevo tipo de aura espiritual. A lo que me interesa apuntar es precisamente a este dislocamiento que ha pasado un tanto inadvertido en cuanto a la construcción de lo siniestro que habla de un cambio en la historia de la consciencia de Occidente. Esta novela es uno de los textos más importantes de finales del siglo XVIII no solamente porque da fe del cambio hacia lo gótico sino porque articula un nuevo momento en la percepción de la experiencia humana que atrapó a los lectores por encapsular nuevas estructuras del sentir, un modelo nuevo de relaciones humanas y una nueva fenomenología del ser y del otro.

Como lo plantea Freud, lo que la mente rechaza en una forma puede regresar a perturbarnos en otra. Así que mientras la ciencia se interesaba en el siglo XVIII por rechazar cualquier naturaleza sobrenatural de la mente, en la literatura volvía cada vez con más potencia afectando la conciencia popular. En la narración de Radcliffe lo que fue real se vuelve irreal y viceversa. Es durante este proceso de inversión y de retorno que los dos ámbitos comienzan a confundirse: el lenguaje arcaico de lo sobrenatural contamina el lenguaje nuevo de la experiencia mental. Los fantasmas y aparecidos mantienen su ambiguo agarre de la imaginación sólo que ahora han migrado al espacio de la mente. Algo similar sucede en el trabajo de McQueen.

Terry Castle sugiere que una de las características más importantes de esta nueva sensibilidad es la sensación de espectralidad del otro. ${ }^{86}$ No es coincidencia, entonces, que una de las teorías más importantes con respecto al funcionamiento de la mente, el psicoanálisis, haya interiorizado la metáfora del acto de ver fantasmas. Toda la teoría Freudiana está cubierta de esa misma sobre-naturalización que maneja Radcliffe. Esta preocupación con las supuestas apariciones mentales y lo que se ha entendido a partir de ellas -gracias a Freud- sobre su control sobre nosotros. Todo este recorrido es el trayecto de las evocaciones de una nueva excepción cognitiva de los contenidos de la mente

En este sentido, las ideas de Benjamin tienen una gran relevancia para comprender el trabajo del McQueen y estas analogías que hago con ciertos eventos del siglo XVIII. Sus ideas le ofrecen a la historia del arte y a la estética un modelo complejo y sofisticado de cómo funciona la seducción visual pues están predicadas sobre el

${ }^{86}$ Ibid. Pp. 124. 
entendimiento de cómo funcionan las comparaciones visuales. Su método permite percibir similitudes entre periodos aparentemente separados por la ruptura y la discontinuidad y comprender el tiempo histórico no como algo que fluye directamente del pasado al presente sino como retornos y encuentros complejos en donde el pasado es activado por medio del presente. En Tesis sobre la filosofía de la historia Benjamin dice,

"La Revolución Francesa se entendió a sí misma como una Roma que retorna. Citaba a la Roma antigua igual que la moda cita un ropaje del pasado. La moda husmea lo actual dondequiera que lo actual se mueva en la jungla de otrora. Es un salto de tigre al pasado.,87

Benjamin sabía que la verdadera dialéctica de la moda era su habilidad de re-fabricar lo muy antiguo como lo más novedoso por lo tanto la tercera imagen en esa dialéctica es un fantasma que revela ese constante devenir. Es ese salto de tigre el que describe el movimiento de desdoblamiento de las prendas de McQueen. Tal como Proust lo formula en el concepto de mémoire involontaire que refiere a los encuentros involuntarios con ciertos objetos o elementos en las prendas y que retrotraen a experiencias que de otra manera se hubiesen mantenido ocultos, latentes u olvidados.

Con el corset con lombrices -parte de la colección titulada The Hunger (Placa 15) McQueen se detiene a fetichizar otro componente de la moda que no es precisamente el lujo y deconstruye las clásicas técnicas de la moda basándose en lo abyecto y lo corrupto. Las lombrices como recordatorio de lo podrido y deteriorado recuerdan a la figura del pensador vagabundo que tanto fascinó a Baudelaire y a Benjamin. E vagabundo hurga entre la basura tratando de recuperar el detritus cultural olvidado por las sociedades capitalistas. En ese andar, se encuentra con desechos y demás inmundicias que bien podrían estar infestadas de gusanos. Esta pieza de McQueen, hace alusión a la muerte y la putrefacción como parte del constante ciclo de la vida y del consumismo. Además, se crea una interesante imagen dicotómica en la que aparece la mujer de la moda, la modelo llena de lujos y el vagabundo, es decir, la tesis y la antítesis. Es justamente cuando estos opuestos se superponen que lo siniestro aparece revelando un tercer momento que parece haber sido suprimido. Esta vuelta compulsiva y grotesca del pasado sugiere la presencia de factores que van más allá del mero trabajo de confeccionar moda que refleje los cambios por los que se estaba pasando en la década de los noventa sino que también puede ser una manera de acomodar y entender la naturaleza inquietante de tales cambios operando en una especie de retorno de lo reprimido en donde la moda se convierte en un síntoma en donde se articula un trauma cultural.

\footnotetext{
${ }^{87}$ Benjamin, Walter. Tesis de filosofía de la historia. Ed. Angelus Novus. Barcelona, 1971. Pp. 84.
} 
En este sentido el corset con gusanos habla de ese trauma cultural que es inherente a la experiencia moderna de finales del siglo XX marcado por las guerras, el terrorismo y el totalitarismo y a la no menos banal consecuencia atribuida a los rápidos cambios en el consumo de Occidente en donde la moda representa esto a la perfección. La cultura se encuentra atrapada entre lo nuevo y lo perecedero. Un campo de acción cada vez más vertiginoso en donde los medios de comunicación han acelerado aún más el proceso de consumo a tal grado que cualquier cosa nueva y bella aparece ya desde antes con los fantasmas que auguran su muerte. La moda de McQueen es el paradigma de esta premisa y es por esa espectralidad mortífera que una cualidad siniestra es posible.

El periodo en el que McQueen trabaja está marcado por un inminente sentimiento de final y esto se ve reflejado en sus prendas en la manera en la que evoca la historia y el pasaje del tiempo como un trauma en el presente. La repetición compulsiva del desdoblamiento de la historia es muy similar a las estructuras del trauma. Freud argumentó en Más allá del principio del placer, que luego de la Primera Guerra Mundial muchos soldados sufrían de shock, permitiéndole así comprender y estudiar la repetición compulsiva del trauma, en donde, por ejemplo, el sujeto podía revivir constantemente la experiencia en sueños como una forma de intentar dominarlo. Freud aseguraba entonces que los histéricos sufrían de reminiscencias. Por supuesto el trabajo de Freud hace alusión a individuos que sufrían ciertas patologías y no a la noción de trauma cultural que predominó la producción de los noventa, pero este aforismo puede ser sin duda utilizado. Para finales del siglo $\mathrm{XX}$, tal como los pacientes histéricos de Freud, la moda de McQueen presentaba constantes reminiscencias. Sus rumiaciones sobre el pasado y el imaginario que trabajaba parecían hacer hincapié en lo siniestro y por lo tanto, sus ropas diseñadas a partir de imágenes del pasado pueden y deberían ser entendidas como un tipo de retorno de lo reprimido.

Derrida dijo en Los espectros de Marx que toda época tiene su propia escenografía y sus propios fantasmas. Con los trabajos de McQueen estos fantasmas se volvieron reales por medio de las prendas. Hay muchas formas en las que la moda puede ser espectral. Por ejemplo, varias de las prendas del diseñador son tan elaboradas que fueron usadas solamente una vez durante la pasarela y luego entraron al circuito de los museos y galerías. Tal es el caso del vestido de la colección titulada VOSS (Placa 16), confeccionado a partir de dos mil láminas para microscopio pintadas a mano de color rojo para representar la sangre que se encuentra siempre debajo de la piel y 
cosidas a una falda de plumas de avestruz. En este sentido muchas de sus prendas son espectrales pues sólo fueron usadas una vez y por muy pocos segundos para luego desaparecer y ser tan solo una imagen en la memoria del espectador.

Las pasarelas de McQueen mostraban ropas tan extraordinarias que su uso se limitaba a una sola presentación y no representaban de ninguna manera a la ropa real que se vendía en las tiendas. El espectáculo en que eran presentadas ratificaba esa idea y seducían a través de una híper-realidad. Lo que Hal Foster propone se ve materializado a través de los vestidos de McQueen. Foster en El retorno de lo real plantea que el espectador se ve envuelto en la lógica del espectáculo porque se ve afectada la pérdida de lo real y al mismo tiempo es a través de las imágenes que se provee lo necesario para suavizar o negar esa pérdida. Sin embargo, en el trabajo del diseñador lo real no está completamente perdido sino solamente reprimido. McQueen viste fantasmas y a los habitantes de la imaginación. La moda propuesta por él es el lugar donde los fantasmas del pasado se reagrupan en el presente.

La palabra espectáculo hace referencia a una función o entretenimiento público que se celebra en un edificio, teatro o lugar en que se junta la gente para presenciarla. Es entendida como cualquier cosa que se ofrezca a la vista o contemplación intelectual y es capaz de atraer la atención y mover el ánimo de las personas infundiendo deleite, asombro, dolor $\mathrm{u}$ otros afectos. ${ }^{88} \mathrm{Al}$ igual que la palabra espectro, ambas provienen de la misma raíz latina specere, que quiere decir "ver". El autor Martin Jay, en su libro titulado Downcast Eyes, define a la sociedad del espectáculo como una serie de imágenes disecadas que traen consigo a la muerte; mientras que Guy Debord en La sociedad del espectáculo afirma,

"El espectáculo en general, como inversión concreta de la vida, es el movimiento autónomo de lo no-viviente. "89

El espectáculo viene de la mano con el concepto de fantasmagoría, palabra que es definida por el diccionario de la Real Academia Española de la siguiente manera:

(Del fr. fantasmagorie).

1. $f$. Arte de representar figuras por medio de una ilusión óptica.

2. f. Ilusión de los sentidos o figuración vana de la inteligencia, desprovista de todo fundamento.

\footnotetext{
${ }^{88}$ El Diccionario de la lengua española $(D R A E)$ es la obra de referencia de la Academia. La edición actual -la 22. ${ }^{\text {a }}$, publicada en 2001.

89 Debord, Guy. La sociedad del espectáculo. Observaciones filosóficas. Madrid, 1967. Pp. 2.
} 
Lo que me parece importante, además de que es interesante saber el origen de la palabra, es el acercamiento que el entendimiento del concepto aporta. El término fantasmagoría fue cambiando poco a poco. Primeramente, fue conectado con algo externo y público pues los espectáculos de la linterna mágica eran verdaderos eventos masivos ya que producían ilusiones espectrales artificiales. Luego, la palabra comenzó a ser usada para referirse a algo completamente interno y subjetivo, o sea, el imaginario fantasmático de la mente como ya lo mencioné más arriba. Ese cambio metafórico habla de una transformación en la conciencia humana muy significativa y lo que Terry Castle define como la espectralización o la fantasmatización del espacio mental. ${ }^{90}$ Lo que esto quiere decir es la inclusión de los fantasmas en el mundo del pensamiento.

A pesar de que el individuo ha hecho a un lado la creencia de un mundo espiritual como en el que creían sus ancestros o de igualar el ver fantasmas a tener mucha imaginación, otro movimiento paralelo se gestó: el de creer en la naturaleza espectral de nuestros pensamientos. La actividad imaginativa de la mente es, a finales del siglo XVIII, una forma de ver fantasmas. Esto está tan arraigado ya en la persona que consideramos esta creencia como algo racional y no hay duda de que esta manera de pensar es parte fundamental para validar los puntos de vista lógicos. Por ejemplo, los fantasmas son cosas de la mente, o al menos eso es lo que a todas las personas se les indica desde pequeños. A todos los individuos se les ha enseñado que ver cosas que los demás no pueden ver -monstruos, fantasmas o figuras extrañas- es simplemente un acto de la imaginación o el acto de interaccionar con una forma intensa de pensamiento. Por supuesto, la actitud racionalista, podría decirse, depende enteramente de esta forma primaria de internalización de lo espectral, pues mientras el mundo externo se vea poblado de espíritus -buenos o malos- la mente se mantiene inconsciente de sí misma, enfocada en otras cosas, incapaz de asegurar tanto su autonomía o su responsabilidad creativa sobre el mundo.

Por lo tanto, lo que la evolución del término trae consigo es mostrar cómo se intenta racionalizar la mente. El haber intentado suprimir el mundo de los espíritus de los ancestros y humanizar el elemento "demoníaco" de la vida humana produce un movimiento contrario al esperado: al negar el espacio de los espíritus en el afuera, las personas se vieron obligadas a reubicarlo dentro de la teoría de la imaginación.

${ }^{90}$ Castle, Terry. The Female Thermometer. Eighteenth-Century Culture and the Invention of the Uncanny. Oxford University Press. New York. 1995. Pp. 141. 
Los espectáculos mismos de fantasmagoría eran la muestra de que los fantasmas no existían en el exterior y que podían ser reproducidos mediante una técnica de luz. Eran la forma que tuvo la ciencia para exponer a charlatanes que decían poder ver espíritus pero al mismo tiempo que esta era la intención principal, estos eventos comenzaron a tener más publico porque algunos espectáculos nunca revelaban sus secretos para lograr las apariciones de fantasmas dándole a todo el suceso una sensación de misterio y extrañeza. En oscuridad y con sonidos extraños contrariamente a explicar las apariciones, lo que la fantasmagoría empezó a hacer fueron shows que recreaban el aura emocional de lo sobrenatural. Las personas sabían que los fantasmas no existían pero aun así los veían sin saber exactamente cómo. De igual forma, cuando el concepto se traslada a la mente y para explicar las imágenes que ésta produce, la metáfora nunca termina de explicar bien el mecanismo mental.

No es de extrañarse que durante el siglo XIX se piense sobre los procesos mentales como los de una linterna mágica capaz de proyectar imágenes o huellas de sensaciones pasadas. Sin embargo no debe olvidarse que el término de fantasmagoría nunca fue capaz de apartarse completamente de la asociación con la magia y lo sobrenatural y es por eso, que al importar su lenguaje a los procesos de la mente, una sensación de inquietud aparece. La mente es una zona de fantasmas con la fuerte tendencia a volcarse en presencias espectrales y obsesiones fantasmales. Al final, el término original de la fantasmagoría como un avance tecnológico cayó en desuso y para finales del siglo XIX los fantasmas desaparecieron de la vida cotidiana pero la vida interior de los individuos se había convertido en la residencia primordial de éstos. A través de un extraño proceso de dislocación el pensamiento se volvió fantasmagórico.

Si algo lograron los espectáculos de linterna fue colocar a los espectadores dentro de un estado de percepción contradictorio y desquiciante. Justamente los espectáculos hacían hincapié en que los fantasmas no eran reales pues podían reproducirse pero su presencia estaba ahí, es decir, no eran consecuencias de la imaginación. La persona pensaba que los fantasmas eran ilusiones presentes solamente en la mente pero durante las presentaciones de la linterna parecían realmente estar presentes como entidades reales y fuera de los límites de la psique. Así que la sensación que se producía era extraña y siniestra en donde se daba una inestabilidad entre el adentro y el afuera, la mente y el mundo, la ilusión y la realidad y donde se confundían las 
imágenes mentales con las reales. El individuo, aunque se daba cuenta de lo artificial que tenía frente a sí, aun así sucumbía a la incontrovertible realidad de lo visto.

Si en algún momento la linterna mágica servía para explicar el mecanismo de la mente, ahora los fantasmas se habían vuelto mucho más reales que antes en el sentido en que ahora ocupaban y preocupaban el espacio intimo de la mente. Los fantasmas proyectados en los shows de linternas no eran reales pero se podían ver; de manera paralela, los pensamientos eran aquellos fantasmas exteriorizados provenientes de los individuos mismos y no había escape alguno. Esta experiencia sensorial de los propios pensamientos es lo siniestro.

No hay que olvidar que el fantasma, entonces, es también un síntoma. Jean-Michel Rabaté en The Ghosts of Modernity argumenta que el Modernismo está poseído por sus propios fantasmas o espectros de la historia que regresan para interrogarlo. En sus palabras,

"Lo que retorna es, de manera clásicamente freudiana, aquello que no ha sido procesado, acomodado e incorporado en el ser a través del duelo; la sombra del objeto perdido sigue siendo proyectada en el sujeto.",91

Para este autor, los fantasmas que habitan la modernidad son aquellos que provienen de su ideología y estética, es decir, son los espectros de la historia que el comienzo del modernismo, con sus utópicas creencias en el progreso y en el futuro, negó. Es por esta razón que el Modernismo está embrujado con esas apariciones de su propio pasado, que vuelven de manera siniestra y desde lo reprimido, tal como lo plantea Freud. Rabaté argumenta que la modernidad como un discurso filosófico trató de borrar la historia porque quería ser radicalmente nuevo. Pero ningún movimiento que intente abolir el pasado puede evitar el retorno de lo reprimido.

Por lo tanto, es en las creaciones de McQueen en donde el pasado y el presente se fusionan, en donde lo siniestro se delinea a partir del retorno de lo histórico reprimido, en donde los fantasmas del siglo XVIII -el antecedente a lo siniestro- regresan como imágenes. Todas las prendas de McQueen presentadas en esta tesis traen consigo esta idea y por ende, pueden ser analizadas bajo el concepto de lo siniestro. El espectro del pasado ha vuelto a rondar el espectáculo de las prendas. Una cualidad al principio imperceptible pero que toca aquellas memorias reprimidas también del que contempla las ropas.

\footnotetext{
${ }^{91}$ Rabaté, Jean-Michel. The Ghosts of Modernity. University Press of Florida. Gainsville, 1996. Pp. 16.
} 
Fueron estos tipos de problemas los que el psicoanálisis intentaría solucionar. Freud estuvo al tanto de los primeros trabajos escritos dedicados al pensamiento y las alucinaciones. ${ }^{92}$ Los textos de Freud, intentando explicar el funcionamiento de la mente, exhiben la misma retórica y las mismas paradojas epistemológicas que los trabajos racionalistas anteriores a él. Él fue el heredero de la concepción de la psique como un espacio vulnerable sujeto al horror de las intrusiones espectrales. Por lo tanto, no es raro que para Freud, tanto como para los primeros escritores que intentaban erradicar a los fantasmas, el pensamiento tuviera una curiosa tendencia a convertirse en algo fantasmal. Las ideas inconscientes son precisamente, para él, esos fragmentos que persiguen al individuo con la gran capacidad de alienarlo. Por lo tanto, la tarea del terapeuta es intervenir en el mundo de la imaginación del individuo y liberarlo de los fantasmas. Sin embargo, al ser productos del inconsciente, éstos se encuentran parcialmente fuera del total control humano y conservan un vestigio de fuerza mágica y una persistencia irracional y aterradora en la mente. La gran paradoja dentro del psicoanálisis es por lo tanto, a estas alturas, que ningún proceso por más científico que sea o ninguna técnica analítica o de auto control podrá erradicar el potencial retorno de los espectros de la mente.

Terry Castle, afirma que desde el principio el psicoanálisis tuvo una dimensión política paralela en el sentido en que era beneficiosa para la burguesía pues proponía la recuperación del control de la potencialmente anárquica y fantasmagórica vida interior del sujeto. ${ }^{93}$ De esta forma, los pacientes histéricos de Freud eran ahora aquellos que antes veían fantasmas pero con un nuevo disfraz. Cada uno de estos individuos debía ser reeducados, reubicados en la sociedad a través de la "cura hablada". Lo importante era alejarlos de la soledad y que hablasen con otro ser humano y no con fantasmas.

La consecuencia de este proceso, en mi opinión, es el origen de lo siniestro, y es que el colocar lo sobrenatural en el ámbito de la psicología no cambia de raíz la naturaleza de lo sobrenatural sino que simplemente se ubica en otro lado. Todas las características de lo sobrenatural permanecen. No se da de verdad el fin del pensamiento mágico sino que se reubica en otra parte sin contemplar las consecuencias y esto produce la demonización del pensamiento, el extrañamiento de

\footnotetext{
${ }^{92}$ Esto se puede encontrar e inferir en La interpretación de los sueños donde Freud cita el trabajo de dos escritores del siglo XIX: Robert Macnish y a James Sully, quienes abordaron el tema del pensamiento y las alucinaciones.

${ }^{93}$ Castle, Terry. The Female Thermometer. Eighteenth-Century Culture and the Invention of the Uncanny. Oxford University Press. New York. 1995. Pp. 185.
} 
las propias ideas y el surgimiento de lo siniestro como la incapacidad de entender el origen de las imágenes mentales.

Mi argumento se centra en que si un fantasma o una aparición representa, según los términos de Freud, una idea sin un fundamento lógico adecuado puesto que viene de un vestigio mágico desubicado e insertado en la mente, la consecuencia lógica en el individuo ante la incapacidad de comprender lo que tiene ante sí, es justamente lo que se denomina como siniestro.

En este sentido, como el trabajo que se hace en el psicoanálisis de recordar los fantasmas del pasado para exorcizarlos en el presente, lo mismo sucede en la producción de este tipo de prendas. En ese proceso psicoanalítico de descubrir materiales reprimidos, hay una similitud con la arqueología. El acto de excavar y encontrar material que ha estado mucho tiempo enterrado es lo mismo que se trabajó en las creaciones de McQueen al mostrar vestidos e ideas que apenas han sido develadas para mirarlas con la nueva luz del presente. Tal cual sucede en el proceso de la arqueología es en psicoanálisis en donde una memoria perdida es recuperada. En este sentido, lo que las prendas de McQueen recuperan tiene que ver con aspectos reprimidos mucho más oscuros y de reflexión melancólica. Trabajando con atuendos que rememoran el pasado y lo reestructuran, McQueen da cuenta que lo nuevo siempre sienta sus bases sobre lo las ruinas de lo pasado. Así es que viste a sus modelos. El diseñador sabe de antemano que su ropa representa una melancólica visión de la vida pues viste a cuerpos que como la historia misma, ya están muertos.

Para comprender mejor esta idea, me remito a lo estudiado por Roland Barthes a través del concepto del retorno de lo muerto y de la restitución del tiempo abolido. ${ }^{94}$ Barthes al mirar una fotografía se da cuenta que los sujetos en ella, tan presentes y vivos en la imagen, ya están muertos, inclusive afirma que al momento de ser tomada la foto, las personas ya estaban muertas de antemano en un futuro. En este sentido hace referencia a una especie de vértigo del tiempo. En la moda de McQueen, algo similar pasa: el imaginario con el que trabaja trae consigo la inestabilidad de pasado al presente de forma vertiginosa. Es decir, sus prendas visten a esos muertos en el futuro y proyectan esas ruinas al futuro.

\footnotetext{
${ }^{94}$ Barthes, Roland. La cámara lúcida. Notas sobre la fotografía. Ed. Paidós. México, 1990.
} 
Lynda Nead, escribe que la modernidad no sólo se ve perseguida por las ruinas del pasado sino que al mismo tiempo se ve poseída por visiones distópicas del futuro. ${ }^{95}$ En las ropas que formaron parte de la colección titulada Widows of Culloden ${ }^{96}$, McQueen juega con el retorno de los muertos a través del pasado urbano de las vestimentas de las mujeres que perdieron a sus maridos en las sangrientas batallas de Culloden (Placa 17). Aquí la viudez no solamente se presenta en el negro del luto sino en la aparición de los fantasmas del pasado evocados a través de las ropas y en las ruinas de las vidas que se intentan recuperar por medio de la representación del luto. Además, para remarcar el concepto del espectro que retorna, en la pasarela misma se proyectaba el holograma de una modelo flotando como un fantasma y de forma siniestra.

Es así que McQueen construye un sitio de vestigios arqueológicos a partir de sus vestidos y de la presencia de algo que no se ve, de los espectros y los aparecidos. Construye una metáfora espacial de las ruinas en donde sus creaciones son una serie de retornos melancólicos del pasado.

Ya Robert Burton en Anatomía de la melancolía afirma que aquellos con un excedente de humores melancólicos son propensos a ver apariciones; Thomas Hobbes dice en el Leviathan, que ver o soñar con apariciones nada tenía que ver con dios sino con el desánimo de algunas partes del cuerpo. Sin embargo, estas creencias fueron rechazadas y nuevas posturas se tomaron. Así cientos de polémicos tratados sobre apariciones surgieron durante el siglo XVIII en Inglaterra, Francia y Alemania. Los autores eran casi siempre médicos interesados en erradicar la superstición y darle una explicación lógica a supuestos fenómenos sobrenaturales. En tales escritos se decía que las alucinaciones espectrales se debían a mala digestión, un estado alterado de los nervios, circulación irregular o alguna otra peculiaridad sensorial que obligaba al cerebro a "renovar" alguna impresión visual o auditiva del pasado. Este efecto vuelto a traer se manifestaba sobre el cerebro como si fuera un objeto externo logrando que la persona se sintiera aterrada. Las imágenes más probables a renovarse, eran aquellas que originalmente se habían impreso con una gran sensación de miedo y horror. ${ }^{97}$ Básicamente, todos estos libros proponían la misma premisa: todos los fantasmas y

\footnotetext{
${ }^{95}$ Nead, Lynda. Victorian Babylon: People, Streets and Images in Nineteenth-Century London. Yale University Press. New Haven y Londres, 2000. Pp. 212-214.

${ }^{96} \mathrm{La}$ batalla de Culloden fue la última de los levantamientos Jacobitas. Cerca de dos mil hombres murieron y más fueron tomados como prisioneros dejando a una gran cantidad de mujeres viudas.

${ }_{97}$ Para ver más sobre este tema consultar el libro de John Ferriar titulado An Essay Towards A Theory of Apparition. En Francia, uno de los trabajos más importantes de este tipo, y uno de los más influyentes en el campo de la psicología anterior a Freud, fue el de Alexandre Brierre de Boismont llamado Des Hallucinations: ou, Histoire raisonnée des apparitions, des visions, des songes, de l'extase, des rêves, du magnétism et du somnambulisme. Consultar bibliografía para más información.
} 
apariciones eran producto de la imaginación. Lo que faltó durante esa época, fue dar cuenta de que el pensamiento era en sí mismo un proceso espectral y por lo tanto, fácilmente modulado hacia la alucinación.

\section{El desencanto del futuro que se esconde}

La obra de McQueen también se ve perseguida por las apariciones del futuro. Como en un laberinto, el pasado y el futuro junto con el presente se encuentran en distintos puntos confundiéndose. En la colección llamada Plato's Atlantis se veían trajes que evocaban imágenes de un futuro apocalíptico. Sus figuras y texturas recuerdan a una especie de ser marino del cual hemos evolucionado y al cual tendremos que retornar por haber destruido el planeta (Placas 18, 18a y 18b). Es a través de estas piezas que se articula la sobre-posición de aquellos miedos provocados por el futuro y las fantasías que éste evoca. Así, nuevamente el diseñador viste a los fantasmas de un pasado que traerá consigo ese futuro aterrador. La dislocación del tiempo y la presencia de lo pasado que debería de mantenerse en el antes, hace uso de un tiempo dislocado, el tiempo de lo siniestro. Las prendas de esta colección y de la anterior aparecen siniestras ante los ojos del espectador pues como lo afirma Derrida,

"No solamente de dónde viene el ghost sino, en primer lugar, ¿va a volver?, ¿no está ya llegando, y adonde va?, ¿y qué hay del porvenir? El porvenir sólo puede ser de los fantasmas. $Y$ el pasado. (...) ¿Es la diferencia entre un mundo pasado - cuando el espectro representaba una amenaza por venir- y un mundo presente, hoy que el espectro representaría una amenaza que algunos querrían creer pasada y cuyo regreso todavía, todavía en el porvenir, habría que conjurar?"98

Rosalind Williams en su libro titulado Dream Worlds propone que la seducción de las comodidades en el siglo XIX se ubica precisamente en la manera en lo que lo real se ve velado por un mundo de ensueño en donde el consumidor se pierde en la fantasía y la ensoñación. ${ }^{99}$ En este sentido, la ropa de McQueen parece ser una evocación de esto. McQueen fue uno de los principales diseñadores en comprender el valor agregado del espectáculo a sus prendas.

El papel que jugó la presentación de las ropas en la década de los noventa fue crucial para el diseñador. Las pasarelas eran consideradas una nueva especie de performance. Mucho se especuló sobre la convergencia entre el arte y la moda en ese momento. Estas condiciones se dieron pues los diseñadores de ese momento no tenían nada que perder de la presentación exuberante de sus trabajos y sí mucho que

98 Derrida, Jacques. Espectros de Marx. El estado de la deuda, el trabajo del duelo y la nueva Internacional. Editorial Trotta, Madrid,1998. Pp. 50-52.

${ }_{99}$ Williams H.,Rosalind. Dream Worlds: Mass Consumption in Late Nineteenth Century France. University of California Press. Los Ángeles, 1982. 
ganar dentro de la industria británica de la moda. McQueen formó parte de una serie de diseñadores que eran llamados fashion desperadoes, frase que intentaba describir las difíciles condiciones a las que se tenían que enfrentar los diseñadores nuevos. Es decir, por ser jóvenes, no reconocidos y sin dinero, los modistos tenían que apostar todo a la presentación de sus vestimentas. Por esta razón las primeras pasarelas de McQueen presentaban a las modelos con un maquillaje con el cual parecían estar golpeadas, sucias y ensangrentadas (Placa 19). Luego de este primer show y de haber llamado la atención en las personas correctas, sus presentaciones se volvieron menos violentas pero más espectaculares como por ejemplo aquellas en las que bañaba a las modelos en lluvias doradas (Placa 20) o envueltas en tormentas de nieve (Placa 21). Sus pasarelas, al igual que las ropas, hablaban de un fuerte sentimiento de desencanto con el mundo.

La colección de otoño-invierno de 1999-2000 de Alexander McQueen presentaba las prendas diseñadas sobre maniquíes (Placa 22 y 22a) con el rostro de fibra de vidrio transparente. La pasarela era la tradicional pero en ella no caminarían mujeres vivas sino que de distintos puntos en el suelo se abrirían compuertas que elevarían a los maniquíes y una maquinaria los haría rotar para luego volverlos a hundir en la oscuridad de la que emergían. La periodista Laura Craik escribió con respecto al evento,

"El espectáculo era fascinante. Nunca se vieron maniquíes tan vivos."100

Debajo de la pasarela se encontraba todo un mundo de muñecas que eran vestidas rápidamente y luego formaban parte de una maquinaria que las elevaba y las hacía descender una y otra vez. Igual que la muñeca Olimpia en el cuento de Hoffmann, la animación de objetos se tornó siniestro, y a la manera más pura de Spalazzini, el mismo Alexander McQueen terminó su presentación emergiendo de la oscuridad de lo inanimado. Las imágenes fantasmagóricas que se generaban en el espectáculo no pueden más que remitir y presentar de manera clara y contundente la presencia de lo siniestro en el trabajo del diseñador. El puente de unión entre lo animado y lo inanimado hacía referencia a la vida y la muerte. Igual que la linterna mágica y las proyecciones de supuestos fantasmas en locaciones lúgubres del siglo XVIII, los maniquíes de esta colección aparecían y desaparecían como espectros. Igual que los eventos fantasmagóricos, esta presentación creó ilusiones ópticas entre lo vivo y lo muerto, creando una decepción visual muy dramática. La audiencia contemplaba lo que sucedía con una sensación particular pues la sustitución de la modelo por lo inanimado despertaba aquello de siniestro que se encontraba.

$\overline{100}$ Craik, Laura. The Guardian. 19 de julio de 1999. 
Igual que la muñeca Olimpia, los maniquíes de esta colección subían y bajaban en posturas estáticas evocando una cualidad de vida en lo muerto, dándole un aspecto siniestro a todo el evento, incluso las ropas, pues son vestimentas destinadas a cuerpos sin vida. Lo siniestro de la presentación de McQueen era sobrenatural. Sus modelos delineaban un lado de la moda más oscuro y que parecía emerger de un pasado extraño. $\mathrm{Si}$, tal como lo planteó Rabaté, los fantasmas de la modernidad vuelven porque ésta ha negado toda su conexión con el pasado, entonces, estas mujeres sin vida retornan siniestras y aberrantes. La constante necesidad de la moda de innovar -como ya lo planteé- hace que se rechace o se reprima el pasado, pero en ese sentido y especialmente en este trabajo de McQueen, el pasado vuelve de forma perturbadora y el presente se mantiene siempre en contacto directo con ese pasado fantasmal. Sin embargo, este diálogo que se genera, entre distintas dicotomías no es simplemente un caso de contraste de opuestos sino también entre las profundas ambigüedades que se pueden encontrar entre ambos tiempos.

\section{La naturaleza de lo muerto}

Pero, ¿de dónde viene esta construcción de lo siniestro en los objetos inanimados que parecen estar vivos? El barómetro fue parte de los grandes acontecimientos técnicos que demostraban el triunfo de la nueva ciencia y la urgencia que se tenía por racionalizar lo que no podía verse. Estos instrumentos funcionaban a partir de las fluctuaciones del mercurio dentro de un tubo de cristal calibrado y -al igual que los termómetros- medían los cambios de temperatura y de presión del aire-. Precisamente por esta manera de funcionar, con una especie de nerviosismo hacia el ambiente, tanto el barómetro como los autómatas -máquinas que simulaban los movimientos o a los seres animados- trastocaban la presunta distinción entre los cuerpos y las máquinas. A partir de la construcción de esta semejanza, no pasó mucho tiempo antes de que los artistas y los escritores comenzaran relacionar el mercurio con la sangre y el cristal con la piel.

Estos pequeños acontecimientos fueron dando vida $\mathrm{y}$ forma al sentimiento de inestabilidad e inquietud que reinó a lo largo del siglo XVIII. Este primer acercamiento puede resultar una forma vaga y primitiva de mostrar la humanización de la tecnología pero sin duda sugiere la profunda tendencia de la cultura de Occidente de animar los productos poco familiares provenientes de la nueva ciencia con sentimientos y capacidades humanas. 
La idea de relacionar los movimientos del mercurio en el barómetro con los caprichos de los sentimientos humanos fue desarrollándose rápidamente a lo largo del siglo XVIII. A partir de un gran nivel de abstracción intelectual, las teorías tradicionales para describir el efecto del clima en la naturaleza humana sentaron las bases para una conexión filosófica con las emociones humanas.

El nuevo paradigma en el cual el barómetro era reinterpretado como la manera de leer la psique humana, comenzó a tomar forma y se dio un movimiento dentro de la literatura de escritos sobre personajes que registraban sus actividades minuto a minuto y donde algunos individuos con personalidades hipocondríacas utilizaban el barómetro para llevar un control sobre las condiciones climáticas y sus estados de ánimo y físicos. Las historias que se leían eran recuentos del cambio de la vida interior del hombre y sus emociones. Pero estos trabajos no eran simplemente una burla a la sociedad burguesa del momento, sino que eran el comienzo del ennui del que tiempo después hablaría Baudelaire y de un nuevo tipo de hombre cuya existencia e interés se había volcado a sentir y registrar su clima interior. Esta nueva auto-consciencia, simbolizada por la fijación de las personas con el barómetro, desplaza el mundo externo de los hechos al interior del hombre. ${ }^{101}$

En el siglo XIX Hoffman y su cuento El hombre de arena harán uso de este proceso. En este cuento, Coppola -la figura demoníaca que despierta en el desafortunado Nathaniel aquellas terribles memorias infantiles que finalmente lo llevan a su muerteaparece por primera vez en la historia como un horrible vendedor ambulante de barómetros y termómetros. Nathaniel identifica a este hombre repulsivo con el odiado abogado Coppelius, un misterioso amigo de la familia, quien en su niñez hubiese relacionado con el terrible monstruo conocido como el hombre de arena que arranca los ojos a los niños. Durante la extraña visita de Coppola a Nathaniel, este último se ve envuelto en un terrible pánico lleno de confusión y recuerdos. Nathaniel rechaza comprar cualquier tipo de barómetro pero finalmente adquiere un telescopio para deshacerse de la presencia del hombre. Sin embargo, Nataniel no logra desprenderse

\footnotetext{
101 Uno de los grandes ejemplos de esto fue el trabajo titulado Ensoñaciones del paseante solitario de Jean-Jacques Rousseau. En su escrito ya no se ve a un hombre tomando registro de las fluctuaciones de ánimo consideradas patológicamente femeninas, sino que él mismo se convierte en observador y observado, es decir, es al mismo tiempo el científico y la mujer que se deja llevar por sus sentimientos. Esta nueva forma que utilizó el autor para presentarse, auto consciente y sexualmente ambigua lo coloca como una especie de precursor de la nueva psicología humana, es decir, el que trazó de manera contundente el proceso cultural que se estaba llevando a cabo en la sociedad y la incorporación histórica de la feminidad, con toda su volubilidad y patología, en la vida interna del hombre. Como ya se sabe, es con Rousseau que se abren las puertas al Romanticismo y esta nueva imagen de un hombre sensible recorre toda Europa, al mismo tiempo que el barómetro era universalmente aceptado como la nueva metáfora de la sentimentalidad masculina.
} 
de la imagen-presencia terrorífica de Coppola/Coppelius/el hombre de arena y gradualmente desciende a una locura suicida. ${ }^{102}$

De cierta forma, pidiendo prestado el término al psicoanálisis se puede pensar que el barómetro es un objeto de transición dentro de la vida psíquica de Occidente. No solamente se utilizó para simbolizar la feminización de la naturaleza humana, sino que facilitó el proceso y alentó la universalidad de la sensibilidad.

Este diálogo fantasmal entre el mundo exterior y el interior -término acuñado por Lynda Nead- se encuentra representado muchas veces en los trabajos de McQueen. En su colección titulada Eclect Dissect (Placas 23, 23a, 23b y 23c) las mujeres eran los fantasmas que volvían luego de ser asesinadas por un científico que las reconstruía a su placer. En esta colección de ropa el concepto de una serie de modelos representando fantasmas ejemplifica de manera perfecta el espectáculo que es la moda con su énfasis en el drama y la narrativa y la presencia fantasmal como metáfora central. Sin embargo, ese diálogo al que alude Nead traza una conexión no tan literal y más profunda entre lo pasado y lo presente y tiene que ver más con la relación de las comodidades a las que la moda hace referencia y los miedos y deseos humanos. Si algo provoca el sentimiento de lo siniestro en el trabajo de McQueen es precisamente esto: la metáfora de la empresa capitalista encarnada en los maniquíes muertos que toman el lugar de los seres vivos. Si producen lo siniestro es porque las mujeres vivas están siendo sustituidas por objetos.

Por otra parte, los límites entre lo real y la mente también se ven afectados cuando los personajes se confunden unos con otros en una repetición casi obsesiva y en un mundo fantasmático que parece estar formado por el inconsciente. Freud hace uso en su ensayo sobre El hombre de arena de lo siniestro, la repetición y los dobles, demostrando que los lectores de tal cuento se percatan de los eventos narrados desde la perspectiva de un héroe que está demente y que alucina. Es Freud quien trae nuevamente a colación la vida psíquica infantil, pues plantea que es durante las primeras etapas de desarrollo que somos incapaces de reconocer completamente o

\footnotetext{
102 Con Hoffman y esta historia en particular, es que el barómetro es asociado por primera vez con un ataque de neurastenia masculina. Los barómetros ofrecidos por Coppola pueden ser considerados como un signo metonímico de aquellos cambios salvajes de humor y sensibilidades perturbadas que él provoca en Nathaniel. Los horrores y ataques de Nathaniel, junto con su incontrolable vida imaginaria hablan de esa nueva interioridad masculina caracterizada por un flujo emocional violento y esos vapores casi psicóticos asociados en ese período con la histeria femenina. Con Hoffman finaliza el proceso que comenzó Rousseau. Imágenes similares se dan a lo largo de la literatura de este momento y son conocidas como metáforas bisexuales pero solamente cuando se entienden desde el hecho de que han venido recorriendo un proceso histórico que encapsula la masculinización de lo que en un principio fue un motivo femenino.
} 
como seres diferentes a las personas. Ya que las habilidades de reconocimiento y comparación fisionómica son tan primitivas en estas etapas los individuos sí se parecen todos entre sí.

Este movimiento entre la imagen mental y la realidad espectral es el terreno de lo siniestro. Cuando se intentó desmitificar el mundo espiritual del pasado, los científicos y filósofos de finales del siglo XVIII y comienzos del siglo XIX lo que realmente consiguieron fue colocarlos en el ámbito de la psicología. Los fantasmas no fueron exorcizados sino simplemente internalizados y reinterpretados como alucinaciones. La internalización de las apariciones situó en el centro de la ecuación una irracionalidad latente dentro de las experiencias mentales. Si los fantasmas eran realmente pensamientos, entonces los pensamientos mismos se impregnaban de una esencia fantasmal. La mente se vio subyugada a presencias espectrales. El reubicar el mundo de los fantasmas en el espacio cerrado de la imaginación terminó por sobrenaturalizar la mente. ${ }^{103}$

La autora Lisa Tickner en su libro Modern Lives and Modern Subjects escribe que durante períodos de tiempo donde se da nueva tecnología, tal como el siglo XVIII, las respuestas que se generan ante esto son ambivalentes. ${ }^{104}$ Esto puede aplicarse a la moda propuesta por McQueen en el sentido en que sus propuestas se vuelven fantasmagóricas a partir del uso de la tecnología en la pasarela de los maniquíes. Los fantasmas propuestos por la tecnología, aquellos seres prostéticos en los que se convirtieron las mujeres de esa presentación, esos seres inanimados que de cierta forma amenazan la continuación del ser humano si es que la tecnología lo supera, invierten las relaciones entre objetos y sujetos, otorgándole a los seres inanimados una vitalidad siniestra.

Uno de los espectáculos más siniestros de Alexander McQueen fue el de la presentación de la colección VOSS. El diseñador mandó a colocar una enorme caja de espejos en el centro del espacio, en donde usualmente correría la pasarela. Así, mientras el público se acomodaba en sus asientos se veían obligados a mirar su reflejo bajo una luz muy fuerte. Ya que las presentaciones siempre comenzaban entre una y dos horas tarde, los presentes empezaron a sentirse cada vez más incómodos

\footnotetext{
${ }^{103}$ Este proceso fantasmagórico se da justamente en un momento crucial de la historia Occidental y la creencia de fantasmas. La incredulidad aumentaba cada vez más a través de argumentos científicos. Sin embargo, esto no quiere decir que la creencia en los fantasmas hubiese desaparecido. La religión aún mantenía su poder sobre las ideas de un mundo espiritual trascendente y las personas creían en eso.

${ }^{104}$ Tickner, Lisa. Modern Lives and Modern Subjects. Paul Mellon Centre for Studies in British Art. London, 2000.
} 
al tener que estarse viendo constantemente bajo aquella estridente luz. Aquí el espectador tenía que mirar hacia otro lado, verse a sí mismo o a otros mirándose. Los que observaban se convirtieron en objetos observados, tal como las modelos y los vestidos que estaban por presentarse. Al tiempo, la luz bajó de intensidad en el público y la caja de espejos se iluminó por dentro para mostrar a las modelos. Los espejos eran de una sola vista, es decir, las modelos se podían ver pero no darse cuenta de que eran observadas. Por diez minutos se les podía ver posar y mirar sus reflejos (Placa 24). Para las modelos un nivel básico de narcisismo es parte de su trabajo, es decir, su cuerpo es su sobrevivencia y sus cualidades físicas es una comodidad. Sin embargo, durante esta colección, las ropas se volvieron cada vez más siniestras e inquietantes. Las cabezas de las modelos estaban envueltas en vendas y sus rostros con maquillaje pálido. Las ropas eran de materiales sumamente especiales: plumas, brocados, conchas marinas, corsettes de madera e inclusive había un traje que llevaba en uno de los hombros un castillo construido a partir de piezas de rompecabezas y otro que lucía dos aves (Placa 24a, 24b, 24c y 24d). Uno de los vestidos debía ser portado con un collar que en apariencia era frágil pero cuyas puntas amenazaban con penetrar el rostro de la modelo obligándola a mantener una postura demasiado recta y falsa (Placa e). Luego de que la última modelo hubiese salido, una caja más pequeña en el centro comenzaba a abrirse para revelar el cuerpo desnudo de la escritora Michelle Olley reconstruyendo la famosa fotografía Sanitarium de Witkin. Olley tenía el rostro cubierto con una máscara gris de cerdo con una manguera conectada a su boca mientras una docena de polillas se posaban sobre su cuerpo (Placa f).

Fue esta presentación una de las más siniestras de McQueen pues la belleza y el horror se mezclaban produciendo un sentimiento extraño. Si bien es cierto que la moda es ambigua en cuanto al sexo, casi nunca lo es con respecto a los tipos de cuerpo. La moda no tolera la obesidad. McQueen logró esa dualidad característica de lo siniestro al colocar a esas modelos delgadas mirándose al espejo de forma psicótica y por otro lado, al mostrar el cuerpo de la escritora sugiriendo el horror que produce la gordura en ese mundo. Al disponer de la belleza y el horror al mismo tiempo, se ejemplificaba la ambivalencia intrínseca de la fantasmagoría, es decir, la conversión del placer en algo perturbador y siniestro.

Esta presentación duró tan sólo 15 minutos y tuvo un costo de más de setenta mil libras. Su pre-producción duró más de cuatro meses y fue necesaria la mano de obra de más de cien personas. Muchas de las prendas presentadas serían únicas y no se 
repetirían nunca más. Tal como las presentaciones de la linterna mágica del siglo XVIII, el esfuerzo de producción detrás jamás fue visible y dejaba una fuerte impresión. Igual que la aparición de fantasmas del siglo XVIII ante los maravillados ojos de los espectadores, esta pasarela de McQueen dejaba una fuerte imagen en las personas que tardó bastante en desaparecer. Luego de que todo concluyera, las polillas murieron, las modelos se fueron y todo fue desmantelado y guardado. Igual que un show de la linterna mágica, que viajaba de ciudad en ciudad, de la misma forma este espectáculo desapareció en instantes. Igual que el sentimiento de lo siniestro, fugaz pero penetrante, la idea básica de esta presentación era causar una gran impresión y desaparecer lo más rápido posible dejando al público con una sensación extraña de pérdida.

Casi como un circo, que un día está y al siguiente desaparece, la presentación de voss fue efímera.

Muchos de las presentaciones de los diseñadores de moda de la época de los noventa estuvieron basados en la idea del circo, pero mientras unas estaban llenas de energía y con un ritmo acelerado, otras, como las de McQueen se inclinaban más hacia la presentación de un circo melancólico y alienado. En su colección titulada What a Merry-go-Round el diseñador articuló un lado más oscuro del circo. Escenificando un carrusel enfatizó el lado siniestro de los juegos infantiles al colocar una parte del audio de la película Chitty Chitty Bang Bang. El maquillaje de las modelos era de una especie de payaso oscuro y extraño y uno de los vestidos llevaba arrastrando un esqueleto dorado (Placa 25 y 25a). La moda en ese sentido representada por McQueen es la imagen de la frivolidad y la muerte. Por lo tanto, el cuerpo de las modelos es perseguido por un esqueleto. El filósofo estadounidense Marshall Berman en su análisis de la modernidad argumenta que ésta tiene un lado oscuro. La emoción del mundo moderno, la voluntad de cambiar y el deseo por lo novedoso que lo caracteriza se ve balanceado por un terror hacia la desintegración, es decir, un mundo que se cae y no puede mantenerse unido. ${ }^{105}$

\section{La exquisita monstruosidad de lo doble}

También, Berman dice que una cualidad doble es característica del capitalismo pues su producción depende de una innovación constante -la moda es representante de esto- pero la novedad es enemiga de la tradición y la continuidad, produciendo una

\footnotetext{
${ }^{105}$ Berman, Marshall. Todo lo sólido se desvanece en el aire. La experiencia de la modernidad. Siglo XXI Editores. Madrid, 1988. Pp. 100.
} 
sensación de inestabilidad y dislocación. Además, para que las cosas sean constantemente construidas deben ser de igual manera destruidas, por lo tanto lo contrario a la producción capitalista es la destrucción violenta. Este terror a la desintegración invadió la energía positiva de la modernidad produciendo una estética más oscura y siniestra visible en los trabajos de McQueen en donde las imágenes producidas por sus obras oscilan entre el horror, la belleza, lo siniestro, la muerte, el sexo, el placer y el terror.

El devenir entre opuestos ya se manejaba en el siglo XVIII y fue en el siglo XIX cuando Marx escribió,

"Nos hallamos en presencia de un gran hecho característico del siglo XIX, que ningún partido se atreverá a negar. Por un lado, han despertado a la vida unas fuerzas industriales y científicas de cuya existencia no hubiese podido sospechar siquiera ninguna de las épocas históricas precedentes. Por otro lado, existen unos síntomas de decadencia que superan en mucho a los horrores que registra la historia de los últimos tiempos del Imperio Romano. Hoy día, todo parece llevar en su seno su propia contradicción.",106

Mientras que Marx relacionaba inexorablemente el progreso con la decadencia, Baudelaire asociaba el mundo de la moda con el bajo mundo de la criminalidad. Desde el concepto de fantasmagoría se puede notar la doble naturaleza de la modernidad que vendría después y donde todo porta su opuesto, su propia contradicción y donde el progreso estaría consumido por un síntoma de deterioro. La moda de los noventa, y en especial la de Alexander McQueen fue el paradigma de esta idea y era capaz de expresarla tan bien gracias a aquellas razones por las que precisamente se le critica, es decir, su superficialidad, la obsesión con la belleza y la novedad, el cambio continuo, el consumo ostentoso y el exceso. Es en este sentido en que la moda puede ser colocada justo en el centro de lo contemporáneo, y por lo tanto es capaz de expresar las preocupaciones más escondidas de la cultura. Lo que buscaba McQueen era mostrar los horrores de la perfección y como el glamour en realidad era la otra cara de la desintegración y la miseria. En este sentido, la ropa y los espectáculos creados por él para enmarcar la ropa son siniestros pues manejan el principio básico de este sentimiento que se basa en parte en las yuxtaposiciones de opuestos.

Un antecedente directo a este movimiento de opuestos y los resultados que genera es el texto de Henry Fielding titulado El marido femenino. Se trata de un reporte ficticio sobre una mujer arrestada por vestirse de hombre y contraer matrimonio con otra mujer. Lo que concretamente me interesa de este texto es su naturaleza

${ }^{106}$ Discurso pronunciado por Karl Marx el 14 de abril de 1856 y publicado en el People's Paper del 19 de abril de 1856 
fantasmagórica, es decir, ese estar presente y ausente al mismo tiempo. Por tratar el tema del travestismo -asunto tabú en esa época- la crítica literaria no supo dónde colocar este trabajo y no le dio el lugar que merecía. Por estas razones, el texto se sitúa en una especie de frontera fantasmal pues la narrativa del mismo describe y no describe, dice pero no dice. Ya desde el título El marido femenino, se puede notar un problema semántico y una violación de las categorías pues proyecta una paradoja humana: aquello que no existe pero que sin embargo lo hace, eso que muchas veces es considerado como monstruoso. El reporte mismo de Fielding es paradójico pues se ve envuelto en tener que mencionar lo innombrable, es decir, hablar decorosamente sobre un tema prohibido: el de la mezcla de los sexos.

Dado que la protagonista irrumpe en el orden "natural" de las cosas operando desde un nivel indefinido plagado de opuestos puede decirse que comienza a construir otra de las características que se verán claramente en lo siniestro: la convivencia de contrarios. Este monstruo femenino funciona desde el engranaje de contradicciones y da lugar a lo que posteriormente se hará con mayor libertad en lo que se conoce como los bailes de máscaras.

Lo que Mary Hamilton ${ }^{107}$, la mujer arrestada representa para Fielding y para la gente de ese tiempo, es una fuerza emblemática mayor: el poder subversivo que tiene el cruzamiento de sexos, es decir, el enigma del género, sus límites y las reacciones opuestas que esto genera. La fascinación y el desagrado, el miedo y la atracción, lo femenino y lo masculino, etc.

En este sentido, Hamilton es mostrada como aquella que no se revela del todo y que por esa misma razón es capaz de depredar a los inocentes (otras mujeres). Ella encarna el dislocamiento de conceptos, la confusión, el engaño de la superficie. Una serie de conceptos contrapuestos que van velando la verdadera esencia y que se asemeja a la naturaleza de lo que posteriormente se entenderá como lo siniestro. Un nuevo topos de mujer que se trasviste engendra una realidad de rebelión provocando un sentimiento de incomodidad colocando al hombre en un estado de confusión e indefensión ante aquello que antes le era familiar y mantenía bajo control. Las mujeres que se visten de hombres y el lesbianismo ponen en peligro la jerarquía masculina y

\footnotetext{
${ }^{107}$ Aunque Fielding asegura haberse hecho de la historia de esta mujer a partir de ella misma, es poco probable que haya sido así. Sheridan Baker descubrió a partir de registros que Hamilton nació en Sumerset. A los 14 años abandonó su hogar vestida con las ropas de su hermano y viajó trabajando como una especie de falso doctor rural. En 1746 regresa a Somerset y se casa con la nieta de su arrendadora. Luego de tres meses de matrimonio, y de supuestas relaciones sexuales, la mujer con la que se casa se da cuenta del fraude y la denuncia. La ley, sin saber bien como castigar este actuar, la acusa de vagabundeo y es sentenciada a ser públicamente azotada y a seis meses de cárcel.
} 
borra los límites siempre bien definidos entre los sexos y hace que aquello que se mantenía reprimido en las mujeres salga a la luz de forma voraz.

Hamilton es, sin duda, el emblema del conjunto de opuestos creadores de un sentimiento de temor y ansiedad, pues es el arquetipo teatral que es parte del mundo de la ficción y que atraviesa a la realidad mundana de la cotidianeidad trayendo consigo la confusión y la sensación de que algo olvidado está volviendo, recurriendo. Ella es el constante recuerdo de que hay algo en el ser humano que tiene la posibilidad de volver una y otra vez.

Las ropas de McQueen visten a la mujer desde una construcción de lo femenino como sobrehumano e incluso mortífero. En ocasiones, las prendas son tan excesivas que pareciera que la feminidad se formula como un baile de máscaras en donde el género es entendido más como una cuestión de superficie que de profundidad para reflexionar sobre la idea de lo femenino. En este sentido, las modelos que visten las creaciones del diseñador parecen hacer una especie de transformismo en donde la mujer se viste doblemente de mujer logrando un aspecto siniestro.

En realidad, a lo que estaría haciendo referencia es al concepto del psicoanalista canadiense George Zavataros llamado homeovestismo ${ }^{108}$ con el que se describe la excitación sexual que le provoca a un individuo usar ropa típica de su propio género y en ocasiones hacerlo en forma de parodia. En cuanto a las mujeres que la ropa de McQueen viste, pareciera que este movimiento de homeovestismo logra un efecto muy particular, uno de cierto tipo de amenaza. Son vestimentas que potencia la feminidad hasta convertirla en un tipo de femme fatale seductora cuyos atributos son mortales. Podría decirse que es una forma de Medusa tal y como la explicaba Freud en su texto de 1922, La cabeza de la Medusa en el que plantea que la Medusa es el emblema por excelencia de la mujer que aterroriza por su castración.

Michel Foucault dice que la figura del travestismo es una que rondó fantasmagóricamente al siglo XVIII. ${ }^{109}$ De ser esto cierto, uno puede darse cuenta de que se iba gestando poco a poco una característica más de lo siniestro a partir de los complejos ritmos de atracción y rechazo, además de los problemas de las falsas apariencias donde el travestismo parecía ser una consecuencia obvia. La constante tensión entre la revelación y la represión, la negación y la celebración acercan este

\footnotetext{
${ }^{108}$ Zavitzianos, George. Homeovestism: Perverse Form of Behaviour Involving the Wearing of Clothes of the Same Sex. International Journal of Psychoanalysis, 1972: pp. 471-477.

${ }^{109}$ Foucault, Michel. Herculine Barbin. Introducción. Nueva York. Ed. Pantheon, 1980.
} 
proyecto cada vez más al surgimiento del sentimiento de lo siniestro. Por otra parte, el travestismo ${ }^{110}$, además de hablar de un acceso emocional a ámbitos más sensuales y éticos, también denotaba una función subversiva de la vida del siglo XVIII: no solamente se imponía en contra del orden social sino que además provocaba un extraño poder sobre la imaginación. A partir de la imagen del dandi y la amazona, los moralistas vieron la oportunidad para señalar la afrenta contra lo natural y el orden de las cosas. Durante esta época se entendía que la decencia en una sociedad requería que los sexos pudieran ser identificados sin dar lugar a dudas a partir de la vestimenta y así prevenir irregularidades. Sin embargo, el travestismo fue una de las grandes obsesiones de ese siglo. ${ }^{111}$

Esto es lo que sucede con las ropas de McQueen; éstas le otorgan a la mujer que las viste un poder devastador y generan el sentimiento de lo siniestro a partir del miedo de la castración. En otras palabras, este miedo es expresado a través de la ansiedad de género, es decir, la Medusa se convierte en el emblema de ambigüedad pues no es totalmente femenina ni masculina sino un híbrido monstruoso. Tal como lo describe la autora Marjorie Garber,

"Con su enorme boca, sus rizos de serpientes y su asociación con la feminidad, la castración y la erección, la cabeza de la Medusa termina siendo el desplazamiento de lo indecible del género pues no habla ni de los genitales femeninos ni de los masculinos." ${ }^{112}$

Es esta ambigüedad y amenaza lo que produce, entre otras cosas, lo siniestro en la ropa de McQueen. El sentimiento de indeterminación era lo que creaba la antesala a lo siniestro en los bailes de máscaras ${ }^{113}$ del siglo XVIII así como con los casos de mujeres que vivían su vida disfrazadas del género opuesto. La inestabilidad que

\footnotetext{
${ }^{110}$ Por supuesto que tocar el tema del travestismo puede acarrear contemplaciones sexuales pues no hay duda de que el concepto rara vez se aleja de lo sexual.

${ }^{111}$ Una interesante lectura sobre el tema del travestismo y una de las actrices más famosas del siglo XVIII, Charlote Charke, pueden encontrarse en: Charke, Charlotte. A Narrative of the Life of Mrs. Charlotte Charke, Youngest Daughter of Colley Cibber, Written by Herself. Londres, Whittaker, Treacher, and Arnot, 2013.

112 Garber, Marjorie. Skakespeare's Ghost Writers: Literature as Uncanny Causality. Ed. Methuen. Londres, 1987. Pp.109. Traducción propia

${ }^{113}$ La mascarada tuvo sus orígenes en la segunda mitad del siglo XVIII pero se pueden encontrar rastros de travestismo a lo largo de la Edad Media y el Renacimiento sobre todo en festividades rurales y de estación, durante los cuales los hombres se vestían de mujeres. Pero fue en el siglo XVIII en donde el baile de las mascaras se convirtió en un evento a gran escala, público y urbano, en el que cualquier clase social podía participar sin importar rangos o privilegios. Las fiestas duraban toda la noche, y se podía entrar solamente si se llegaba disfrazado y con boleto en mano, el cual era adquirido como para cualquier otro espectáculo. Ya que era un momento en el que se permitían que las clases sociales se mezclaran, no es de extrañarse que esa libre anonimidad diera paso a otros sentimientos. Los comportamientos colectivos de los que atendían no tenían ningún tipo de restricción. Bailar, beber y jugar lascivamente permitía que el decoro se pusiera a un lado. Obviamente, no tardaron en hacerse escuchar las voces de aquellos que consideraban estas reuniones inmorales y se intentó de todo para detenerlas, pero nunca con éxito. Lo único que sí lograron estos intentos por reprimirlas fue que se volvieran más populares y tuvieran un atractivo aún mayor para las personas, ya que tenían un poder seductivo en la imaginación popular. Fue hasta la revolución francesa que las mascaradas comenzaron a perder su importancia aunque se tienen registros de que algunas se llevaron a cabo durante el siglo XIX.
} 
produce lo híper femenino en esta situación no es tan diferente a lo que ocurría antes. Además, el hecho de que el poder simbólico del falo se encuentre escondido u oculto detrás de la imagen que genera la ropa del diseñador es otra cuestión que determina la presencia de lo siniestro. Lo velado que resurge de manera sutil produce miedo. Por lo tanto, si la Medusa constituye el poder mágico que tiene la mujer sobre los hombres también representa la amenaza de la castración. En cuanto a la imagen de femme fatale con la que han sido descritas muchas veces las prendas de McQueen se estaría hablando del mismo poder de seducción y destrucción. Un glamour siniestro que devela algo escondido. ${ }^{114}$

Ya lo había dicho Fielding, el mundo entero se convierte en una mascarada cuando la hipocresía, los vicios y los engaños comienzan a filtrarse en las buenas conciencias de la sociedad. El siglo XVIII fue una época en la que se pensaba que las corrupciones de la riqueza colocaban a las personas en un perpetuo estado de mascarada en el que les era posible adoptar cualquier tipo de personalidad. ${ }^{115}$ La metáfora del baile de las máscaras hace posible ubicar dentro del movimiento urbano el surgimiento de estados de percepción distintos a los que hasta ahora se vinieron percibiendo pues, dejando la moral de lado, el hombre de este siglo estaba comenzando a auto alienarse y a rodearse de artificios y fantasmagoría. Lo que empezó a mostrarse en la literatura, se trasladaba a la sociedad y viceversa, y puede hasta decirse que la cultura del siglo XVIII es la del travestismo, especialmente en ciudades como Londres o París. No escasean los ejemplos de autores como James Boswell ${ }^{116}$ que para escribir sus textos se disfrazaba de soldado o criminal para poder acceder a los círculos clandestinos de Londres. Pero el movimiento del travestismo se daba a gran escala y de manera pública también, a través de los teatros, prostíbulos y los bailes de máscaras los cuales se volvieron populares en Inglaterra a partir de 1720. El disfraz y el travestismo colectivo ofrecían una forma catártica de escapar de uno mismo y permitían una disimulada revisión de lo cotidiano. La naturaleza proteica de la ciudad misma se reflejaba en la necesidad de la sociedad por metamorfosearse y por la libertad que el disfraz ofrecía. En otro de sus textos, Fielding afirma que,

\footnotetext{
${ }^{114}$ Etimológicamente la palabra glamour es una variación de la palabra escocesa grammar, la cual a partir de su asociación con el aprendizaje de lo oculto quiere decir encanto o embrujo. La palabra fue usada por primera vez por Walter Scott en el siglo XIX. Cf. con Webster's II New College Dictionary. Edición 2004.

${ }_{115}$ Sedgewick, Owen. "The Universal Masquerade."Londres, 1872 en British Enssayists. Ed. Alexander Chalmers. Boston 1908. Pp. 92.

${ }_{116}$ James Boswell (1740-1795) fue un abogado y escritor escocés conocido sobre todo por su biografía de Samuel Johnson. Su vida fue especialmente licenciosa, frívola y disoluta: solía salir de casa, y tras pasar semanas enteras entre prostíbulos y tabernas, volver a ella con alguna infección venérea. su figura vivió una gran revalorización, con la publicación de biografías, ensayos y estudios críticas que lo elevaron a una figura prominente del panorama intelectual dieciochesco. Desde luego, Boswell se codeó con los principales personajes de la época y en sus cartas y notas aporta valioso material sobre ellos. Fue Boswell el primer autor a utilizar el adjetivo "romántico" en su obra An Account of Corsiga, donde calificó la isla mediterránea como romántica.
} 
“...el enmascararse es desenmascarar el alma."

La belleza está mezclada con el horror, el espectáculo con la alienación, además, el trabajo del diseñador británico siempre habla del doble aspecto de la moda. Por un lado, construye un discurso en el que se alienta a la persona a ser flexible y moderna, es decir, estar siempre dispuesta al cambio y por otra parte, propone que la moda es el resultado de los aspectos disfuncionales de las democracias modernas pues el mercado lleva a las personas a ser codiciosas, demandantes, egoístas y poco caritativos. Las colecciones de McQueen, en este sentido despliegan el lado oscuro y siniestro de la época y pueden ser interpretados como llamativos y espectaculares pero llenos de horrores y oscuridad. De esta forma sus presentaciones estaban caracterizadas por un sentimiento alucinatorio que Adorno identificaba como la realidad absoluta de lo irreal ${ }^{118}$. Igual que en el siglo XVIII y sus bailes de máscaras o espectáculos de linterna mágica, la naturaleza de la ilusión que se ve en el trabajo de McQueen abole la autenticidad de lo real al presentar pasarelas tan espectaculares y la ropa tan fantástica. ${ }^{119}$

Estas pasarelas al igual que los bailes de máscaras sin lugar a dudas funcionan dentro de muchos niveles pero dada su naturaleza heurística registran el cambio psíquico del ser humano al mostrarlo como aquel que instintivamente funciona en ámbitos ambivalentes, a veces contrarios, a veces complementarios y que lo ubican en una frontera potencialmente ilimitada.

Otra figura relacionada a Hamilton y que aparece constantemente en la producción de McQueen es la femme fatale. Para la autora Mary Anne Doane la femme fatale cinematográfica no hace referencia a la imagen feminista del poder femenino sino más bien al miedo del hombre hacia la mujer. Además, argumenta que la ambivalencia de este tipo de mujer es debida no solamente a que es la portadora del poder sino que

\footnotetext{
${ }^{117}$ Fielding, Henry. The Masquerade. Londres, 1728. Reimpreso en Liverpool: Liverpool University Press, 1960. (Traducción propia).

${ }^{118}$ Theodor W. Adorno. Monografías musicales. Ensayo sobre Wagner Mahler. Ediciones Akal. Madrid, 2008. Pp. 86.

${ }^{119}$ Ya en En la búsqueda del tiempo perdido de Marcel Proust se incorpora la idea de que la linterna mágica y su funcionamiento hunden al niño en un mundo de reflexiones solitarias y a su vez, se emula y se proyecta el trabajo de las imágenes mentales y el efecto de éstas sobre la sensibilidad humana. Bajo la las formas de la linterna, el pequeño se ve envuelto en el fenómeno sobrenatural de su propia mente. Lo que se puede ver es que esta escena proustiana refiere a la clásica conexión del siglo XIX entre la fantasmagoría y el gran poder de aislamiento de la imaginación. Es mi parecer que uno de los sentimientos que se dan durante este proceso es el de lo siniestro. Cf. con Proust, Marcel. En busca del tiempo perdido I. Por el camino de Swann. Spanish eletronic edition. Pp. 112-113.
} 
por eso mismo tiene todas las connotaciones de la enfermedad. ${ }^{120}$ Por lo tanto, si estas mujeres evocan deseo, éste es uno con tiene tintes de terror, es decir, esto es debido a que a mujer fatal es aquella cuya sexualidad es mortal pues destruye a los hombres al mismo tiempo que los seduce. Las ropas de McQueen, visten a una femme fatale post moderna terrorífica dándoles una voz que parece permanecer velada bajo esas prendas, una voz siniestra que habla de miedos que parecían haber sido superados.

Así, precisamente por estas características que se representan en las prendas, la feminidad a la que evoca McQueen es una inestable que oscila entre el glamour y el horror. Además, esta feminidad exacerbada puede en cualquier momento convertirse en psicosis, tal y como se pudo observar en la colección VOSS en la cual las modelos tenían que mirar constantemente su propio reflejo dentro de una caja cerrada o en aquella del carrusel donde personificaban payasos dementes parodiando su propia identidad. La obra de McQueen está plagada de este imaginario que sugiere un siniestro equilibrio entre el horror y el control sobre la feminidad salvaje, cuestión que Simone de Beauvoir desarrollaba en 1940:

“(...) si la mujer se evade de la sociedad, retorna a la Naturaleza y al demonio, desencadena en el seno de la colectividad fuerzas incontrolables y malignas. A la censura que inspira una conducta desvergonzada, siempre se mezcla el miedo."121

En las pasarelas de McQueen, las mujeres parecen disfuncionales en el sentido en que su sexualidad no es franca y directa sino que siempre está configurada como algo complejo, desviado, trastornado o problemático y las imágenes de mujeres que emergen ante tal disfunción son la lesbiana y el vampiro. La filósofa Christine BuciGlucksmann, en su análisis sobre Baudelaire y Benjamin, argumenta que la mujer no es solamente una alegoría de la modernidad, sino que dentro de las grandes utopías antropológicas de la bisexualidad y en las figuras de la lesbiana y el andrógino hay también una protesta heroica contra la modernidad, pues la imagen de la lesbiana no solamente evade la idea del matrimonio y la sexualidad procreadora sino que también encarna la protesta en contra de la modernidad industrial y del sometimiento de la mujer a la reproducción de cuerpos e imágenes. ${ }^{122}$ Para finales del siglo XIX la femme fatale era representada algunas veces como lesbiana y otras, como vampiro. ${ }^{123}$

\footnotetext{
${ }^{120}$ Doane, Mary Anne. Femme Fatales: Feminism, Film Theory, Psychoanalisis. Ed. Routledge. Londres, 1991. Pp. 2-3.

${ }^{121}$ De Beauvoir, Simone. El segundo sexo. Ed. Siglo Veinte. México, 1986. Pp. 104.

122 Buci-Glucksmann, Christine. Baroque Reason: The Aesthetics of Modernity. Ed. Sage. Londres, 1994. Pp.104-108.

${ }^{123}$ Dijksra, Bram. Idols of Perversity: Fantasies of Femenine Evil in Fin-de-Siècle Culture. Oxford University Press. Oxford, 1986.
} 
McQueen trabaja con este imaginario y lo lleva a las ropas produciendo un sentimiento de lo siniestro pues esconde el miedo reprimido de la castración y la sexualidad escondida de la lesbiana. Las ropas de sus pasarelas visten a estas mujeres fuera de control, a estos vampiros o mujeres fatales.

\section{Cadáveres femeninos: las muñecas de McQueen}

Ahora, si el miedo a la feminidad fuera de control se expresa por medio de este tipo de figuras, la representación de la muerte o la locura de bellas mujeres es una forma de tener bajo control el miedo que provocan. La conexión entre la moda y la muerte se ha hecho desde el siglo XIX por el italiano Giacomo Leopardi quien las personificó como hermanas, ambas nacidas de la transitoriedad en su libro Cuentos morales. Por su parte, Freud en su escrito sobre la transitoriedad ${ }^{124}$ dice que la idea de que la belleza es transitoria da un pre gusto del duelo por su sepultamiento. Así nuevamente, en la belleza y la juventud de las prendas se esconde la muerte y la vejez. En otras palabras, la muerte es intrínseca a la moda por más que ésta la quiera negar. Las mujeres muertas que vuelven a la vida en la colección Eclect Dissect representan también la relación directa entre el sexo y la muerte. Las formas artificiales que muchas de la prendas de McQueen despliegan son la representación de lo inorgánico que Benjamin identificaba como la característica principal de la moda y las cualidades mortales que la definen.

Muchas de las colecciones de ropa de Alexander McQueen utilizan este discurso. Aquella titulada Jack The Ripper Stalks His Victims se basó en Jack El destripador y las prostitutas que mataba. La muerte y el sexo estaban presentes en las ropas a través de mechones de pelo haciendo referencia a la costumbre de aquella época de la venta de cabello por parte de las prostitutas para que los amantes pudieran regalarse como símbolo de amor (Placa 26, 26a y 26b). En otras se incluían trozos del propio cabello de McQueen creando un objeto que era un souvenir y al mismo tiempo una especie de memento mori.

Para poder continuar, es relevante pasar al trabajo de Philippe Ariès y su texto titulado Morir en Occidente. Desde la Edad Media hasta nuestros días, pues se especula sobre la compleja relación simbólica entre la vida y la muerte en la conciencia colectiva de los siglos previos al nuestro. Por supuesto, no haré mención al extenso recorrido de este trabajo pero sí a su afirmación de que nuevas y cada vez mayores

\footnotetext{
${ }^{124}$ Freud, Sigmund. La transitoriedad. Obras completas. Amorrortu Editores. Buenos Aires, 1991.
} 
actitudes de represión hacia la muerte se dieron precisamente en el siglo XVIII, constituyendo una verdadera revolución emocional con consecuencias sociales y filosóficas importantísimas.

Ariès propone básicamente que mientras que en la Edad Media la muerte era aceptada como una faceta integral y orgánica de la existencia humana, en la última parte del siglo XVIII, la cultura de occidente demostraba una creciente disociación de la realidad corporal y una nunca antes vista antipatía hacia la muerte en todos sus aspectos. El cambio en los patrones afectivos, el quiebre de la sociedad y la vida en común en pro de una existencia individualista y la naturaleza secular de la experiencia fueron fundamentales para construir un nuevo espíritu de alienación. A través de este proceso de dislocamiento, el autor afirma que la civilización occidental ha reprimido al cuerpo y sus exigencias y ante la muerte se retrae hacia una mistificación ansiosa y hacia la negación. ${ }^{125}$

Por lo tanto, Ariès da cuenta de la presencia de una nueva espiritualización de la experiencia humana que se da a finales del siglo XVIII a partir de dos hechos fundamentales. El primero es lo que él llama como "the beautiful death" o la muerte bella, movimiento que se da dentro de la esfera práctica y la obsesión de la época en esconder o negar cualquier signo físico de mortalidad y descomposición. Lo que antes había sido un espectáculo público de considerable magnitud, ahora era algo privado presenciado solamente por los más cercanos. Además la conservación del cadáver se volvió importante. El embalsamamiento e inclusive la momificación se volvieron prácticas comunes entre las clases altas. Los funerales se volvían cada vez más discretos y a diferencia de los siglos pasados, los muertos eran alejados más de los vivos: los cementerios se alejaron de los centros de las ciudades hacia la periferia y sus funciones necrológicas se oscurecieron.

El segundo evento, y tal vez, el más importante para que se efectuase el cambio de espiritualización a finales del siglo XVIII es, de acuerdo a Ariès, el surgimiento del culto romántico a los muertos, lo que quiere decir una fascinación subjetiva hacia imágenes idealizadas de los fallecidos. Las ideas que se manejaban en la Edad Media acerca de la vida después de la muerte no contemplaban el reencuentro con otros parientes ya fallecidos, a diferencia de este siglo. La muerte era simplemente una ruptura, un final. Sin embargo, durante la época del romanticismo individualista el reencuentro emocional se volvió primordial. La reunión de esposos, hermanos y hermanas, padres

125 Ariès, Philippe. Morir en Occidente. Desde la edad Media hasta nuestros días. Adriana Hidalgo Editora. Buenos Aires, 2012. Pp.53-89 
e hijos después de la muerte en un nuevo "hogar" en el más allá se volvió una de las imágenes básicas del imaginario social de finales del siglo XVIII y comienzos del XIX. La literatura al respecto, las inscripciones en las tumbas y los monumentos funerarios, al igual que los recuerdos de las personas muertas hablaban de esa fantasía de continuidad, una gran cantidad de teorías -no necesariamente religiosas- haciendo referencia a una vida eterna plagada de espíritus reforzaban la creencia popular. Por lo tanto, la muerte ya no era terrible o desagradable pues, supuestamente, la separación física que implicaba era temporal. Ariès atribuye estas nuevas creencias a los cambios en los patrones dentro de las estructuras familiares y las transformaciones en las relaciones afectivas. El autor dice,

\section{"Esta presencia era una respuesta al afecto de los sobrevivientes y a su nuevo rechazo a aceptar la desaparición del ser querido."}

Lo que subyace a esta nueva manera de pensar es el sueño de que los muertos no estén realmente muertos.

Pero lo que tal vez es lo más importante de toda esta reflexión sobre el movimiento de la conciencia en torno a la muerte es la conexión entre el contenido afectivo y un nuevo tipo de introspección. Lo que el trabajo de Ariès parece sugerir es que no solamente se da una respuesta distinta a la muerte sino un modelo de pensamiento completamente nuevo, es decir, una forma de pensar dominada por imágenes mentales nostálgicas. El miedo a la muerte en este momento da pie a un regreso obsesivo al mundo de la memoria, en el que los muertos continúan viviendo. Estas imágenes internas que consuelan a las personas ante la muerte son tan gratificantes que los individuos se ven cada vez más paralizados o impresionados por éstas, perdiéndose en la contemplación misma. Esto es precisamente lo que se conoce como la ensoñación romántica.

Las colecciones de McQueen hablan de violencia, belleza y muerte provocando un sentimiento de lo siniestro a partir de características que hacen pensar en diferentes estados de lo ominoso. En su colección titulada La Pouppée lo siniestro aparece cuando una modelo debía de caminar contorsionada pues tenia las muñecas y los tobillos sujetados a un marco de metal (Placa 27, 27a, 27b y 27c). Lo que el diseñador intentaba lograr era que ese accesorio produjera movimientos mecánicos como los de una muñeca. La colección estaba basada en las muñecas de Hans Bellmer, las cuales fueron desmembradas y vueltas a construir por el artista, un proceso descrito por Rosalind Krauss como construcción a través del desmembramiento. El trabajo de

\footnotetext{
${ }^{126}$ Ibid, Pp. 64.
} 
McQueen se interesó no en reinterpretar el trabajo de Bellmer sino en una compulsión con diseccionar e investigar. El diseñador quería ir más allá y explorar el interior colocando a las modelos en una situación donde pueden ser vistas nuevamente como Olimpias y transgredir los límites entre el adentro y el afuera. La fantasía de explorar y mirar el interior del cuerpo es muy común en el arte contemporáneo pero no en el mundo de la moda, pues éste se enfoca siempre en la superficie. McQueen, por el contrario, investiga el cuerpo femenino en relación a lo abyecto.

La imagen siniestra que McQueen maneja en su ropa se vio reflejada una vez más en su colección llamada Dante. En esta presentación procuró ropa que reflejara a una mujer de sexualidad ambigua y agresiva, una femme fatale peligrosa. Las modelos vestían prendas de estilo militar, sacos brocados con oro al estilo del siglo XVIII, rostros cubiertos con encajes y corsettes que alzaban un cuello de forma violenta. Quizá lo que más llamaba la atención eran los accesorios los cuales lograron construir un imaginario siniestro en el sentido en que no se hablaba directamente de la muerte sino que su presencia se sentía de alguna manera. Una modelo llevaba el rostro cubierto con un tocado tejido y una mano esquelética cubriéndole el rostro, otras lucían antifaces con crucifijos. Garras disecadas de pájaros como aretes, puntas metálicas clavadas en el rostro de las modelos y brazos enredados en accesorios que simulaban alambres de púas y coronas de espinas (Placa 28, 28a, 28b, 28c, 28d, 28e y 28f).

La femme fatale que construye McQueen es una mujer perversa y mortífera que hace eco de los miedos de la sociedad de finales del siglo XX. Tal como ésta representaba las angustias del fin-de-siécle en el siglo XIX -entre ellas el miedo a la sífilis- las representaciones de McQueen también hablan de una mujer portadora de problemas y enfermedades. La mujer fatal del siglo XX se pensaba con relación al miedo a la enfermedad como el sida. Igual que la mujer del siglo XIX, la femme fatale seduce y mata. ${ }^{127}$ Sin embargo, lo que diferencia a una de otra es que la última ya no era un objeto de temor sino que se volvió un sujeto que atemoriza. Es decir, su apariencia altamente sexualizada era una defensa velada dispuesta a atacar y de ahí se desprende su relación con lo siniestro. Las mujeres que visten la ropa de McQueen están arropadas no para provocar desagrado de manera directa sino que a través de su imagen velar el peligro y provocar lo siniestro para mantener a los demás a cierta distancia segura. En la colección Dante una de las modelos portaba un tocado

\footnotetext{
${ }^{127}$ El interés generalizado por el tema del cuerpo parte de los artistas y teóricos $-\mathrm{y}$ en este caso de un diseñador de moda- a finales de los noventa se debió a esa conexión con la enfermedad. En especial la moda y el arte se vieron permeados por el concepto de lo abyecto de Kristeva, lo siniestro de Freud y lo informe de Bataille.
} 
elaborado a partir de cuernos de venado (Placa 28g) creando una poderosa imagen en donde la mujer era vista como salvaje y mitad humana haciendo recordar lo que Baudrillard dice en Las estrategias fatales,

"Imaginad algo bello que hubiera absorbido toda la energía de lo feo: aparece con la moda..." Es decir, esa belleza tocada por un par de cuernos que evocan lo salvaje del animal potencia la idea de que la ropa que McQueen confecciona no es reconfortante sino amenazante, algo primitivo que resurge y que se pensaba superado.

La representación de la sexualidad femenina como algo aterrador no es algo nuevo sino que tiene una larga historia. La ropa de McQueen logra que las mujeres sean vistas desde una triunfante perversión y una exuberante sexualidad. El diseñador las viste para ser una especie de Baubo mostrando sus genitales. Es en esto también en lo que la femme fatale de McQueen se diferencia de la del siglo XIX: estas son mujeres aterradoras y dominantes. Sus vestidos evocan a las grandes mujeres libertinas del Marqués de Sade con sus extensos repertorios de salvaje dominación. Al igual que las mujeres de Sade, las de McQueen son vestidas de tal forma que su imagen tan extrema crea el tropos de una súper mujer que se encuentra más allá de cualquier género. Lo siniestro de estas mujeres predomina en el hecho de que su poder de aterrorizar recae precisamente en esa distancia entre su feminidad biológica y sus acciones que trascienden su género. Siempre en los juegos dicotómicos de los opuestos aparece lo siniestro y McQueen estaba fascinado con esto y sobre todo con la relación entre víctima y victimario, sólo que sus mujeres eran las agresoras. Las pasarelas con la ropa de McQueen sugieren un mundo sin hombres y no porque no existiesen sino porque es un mundo en el que los géneros se ven alterados por la mujer quien es híper femenina y en otros aspectos siniestramente masculina.

En el trabajo del diseñador siempre se encuentran los opuestos, es decir, cada instancia de bondad se ve balanceada por una de crueldad; cada acto de dominación dibuja uno de sumisión. Esto se ve claramente en la colección titulada It's a Jungle Out There en la cual McQueen se interesó en confeccionar prendas que hablaran sobre la gacela y su inmensa vulnerabilidad como presa. Sin embargo, la manera de confeccionar las prendas con cuernos saliendo de los hombros hacía ver a la modelo mucho más agresiva que sumisa, revirtiendo así los pensamientos que se tienen sobre la delicadeza del animal (Placa 29, 29a y 29b) Estas eran las mujeres que McQueen vestía: agresivas, poderosas, terroríficas, siniestras y mitad humanas. Pero en el fondo

\footnotetext{
${ }^{128}$ Baudrillard, Jean. Las estrategias fatales. Ed. Anagrama. Barcelona, 2000. Pp. 6
} 
de esta cruel superficie se pueden encontrar conexiones estructurales que parecen unir los conceptos de víctima y victimario que en un principio parecen tan dispares. El trabajo de McQueen representa un universo trágico, un mundo alienado y donde la sexualidad no habla de amor y felicidad sino de trauma y de otredad.

En la literatura de Sade, Baudelaire, Genet y Bataille esto ya tenia tiempo de trabajarse, pero fue con McQueen que por primera vez se desarrolla en la moda pues era sólo a través de vestir el cuerpo que podía trabajar las imágenes provocadas por los temas del desencanto de finales del siglo XX.

En la colección de cuentos de Bruno Schulz titulada La calle de los cocodrilos y publicada en 1934 los relatos hablan de una serie de maniquíes que cobran vida y se apoderan de la tienda del sastre, capturan a su antiguo dueño y lo desarman como a un muñeco. De igual forma, Alexander McQueen, junto con algunos otros diseñadores de moda de los noventa, lograron trabajar con la misma idea al sustituir con maniquíes a las modelos o jugando con las cualidades robóticas de las mujeres arriba de una pasarela, haciendo hincapié en lo inorgánico a expensas de lo orgánico. Es decir, sus maniquíes y maquinas usadas en la presentación de las ropas hacían eco la idea de un sujeto ambiguo, algo que Émile Zola ya había trabajado en su novela El paraíso de las damas. La joven y provinciana Denise Baudu llega a París luego de la muerte de sus padres. En una escena de la novela, Denise se ve seducida por un aparador de una gran tienda departamental. La vidriera está llena de maniquíes que se multiplican ad infinitum a través del cristal y vestidos con lo mejor de la moda del momento. Así, la protagonista lo que logra observar

\footnotetext{
“...a ambos lados del escaparate, varios espejos sabiamente orientados los reflejaban y multiplicaban hasta el infinito, abarrotando la calle de hermosas damas en venta que, en lugar de cabeza, lucían unos precios rotulados con grandes números." ${ }^{129}$
}

La imagen que Zola construye habla del fetichismo y del espectáculo de la feminidad en el París de 1880 en donde la mujer era tanto un sujeto como un objeto de deseo del consumidor. ${ }^{130}$ La autora Julie Wosk en su trabajo titulado Working Frame argumenta que en el siglo XIX,

"Las imágenes de los artistas sobre los autómatas se volvieron metáforas centrales de los sueños y las pesadillas de las sociedades que transitaban por rápidos cambios tecnológicos.

En un mundo en el cual los avances en materia de tecnología superaban las capacidades humanas y en donde un gran número de personas estaban empleadas en sistemas industriales

\footnotetext{
${ }^{129}$ Zola, Émile. El paraíso de las damas. Alba Editorial. Barcelona, 1999. Pp.4.

${ }^{130}$ Wolff, Janet. The Invisible Flâneuse: Women and the Literature of Modernity, incluido en el compendio Femenine Sentences: Essays on Women and Culture. Polity Press. Cambridge, 1990. Pp.34-50.
} 
en donde era necesario más velocidad y eficiencia, los artistas del siglo XIX le hacían frente a una de las preocupaciones más importantes de las personas: la posibilidad de que las identidades de las personas y sus vidas emocionales se volvieran mecánicas."111

En el siglo XX se observa a la Modernidad como un momento fundamentalmente industrial en donde el mundo y el cuerpo se han disociado, fetichizado y vaciado, transformándolo en un conjunto de elementos mecanizados. Estos mismos elementos volvieron a surgir en la moda de los años noventa con la sustitución de las modelos por maniquíes o máquinas.

En muchas ocasiones, las modelos que McQueen vestía eran maquilladas para lograr un aspecto disfuncional o utilizaban joyería y prendas que las forzaba a adoptar poses espasmódicas. Esto es claro en la colección La Pouppee De esta forma, lo que McQueen está diciendo es que si lo que se quiere es ver a las mujeres como muñecas vivientes, esta es la forma en la que realmente se verían: locas, decadentes, con articulaciones y miembros a punto de quebrarse, pendiendo de una danza siniestra, listas para convertirse en algo terrible, inhumano.

La muñeca que propone McQueen en este trabajo es la representación de la inversión humana del sujeto hacia un "otro" alienado. Sin embargo, es destacable el hecho de que este otro no es neutro en cuanto a género. Esta imagen de lo siniestro en McQueen no sería posible de no ser promulgada a partir del género femenino. Es decir, en esta búsqueda de la mujer por el cuerpo perfecto lo que se logra en su lugar es la perturbación de la mujer convirtiéndola en un autómata.

El mismo efecto es alcanzado en las colecciones It's Only a Game y en aquella titulada The Horn of Plenty. En la primera, McQueen transformó la pasarela en un tablero de ajedrez gigante en el que las piezas eran las modelos quienes en algún momento comenzaron a pelear entre ellas tal como en el juego (Placas 30, 30a, 30b y 30c). La autora Sadie Plant en su libro titulado On the Matrix argumenta que la asociación de la mujer, la modernidad y la máquina data por lo menos de principios del siglo XX, cuando las primeras operadoras telefónicas eran mujeres. ${ }^{132}$ Sin embargo, esta visión utópica de Plant de las mujeres como imágenes o instrumentos de progreso y de un futuro prometedor se ve opacado por aquellas oscuras imágenes que se tienen de la mujer como objetos de consumo y de comodidad en la era de la producción en masa. Y que mejor representado esto que en la pasarela del juego de ajedrez de McQueen.

\footnotetext{
${ }^{131}$ Wosk, Julie. Breaking Frame: Technology and the Visual Arts in the Nineteenth Century. Rutgers University Press. New Brunswick, 1992. Pp. 81. Traducción propia.

${ }^{132}$ Plant, Sadie. On the Matrix: Cyberfeminist Simulations. Routledge. Londres, 2000.
} 
Esta sombra oscura es la misma a la que Benjamin hace referencia en El libro de los pasajes, la que se cernía sobre París, sobre todo cuando hace referencia a Nadja de André Breton, en la cual el poeta se enamora de una figura femenina de cera atándose una liga que se encuentra en el Museo Grevin y en donde Benjamin se da cuenta que no hay nada más siniestro que las formas preservadas en las figuras de los museos de cera.

El mismo efecto visual se logra en la segunda colección, The Horn of Plenty. En este trabajo McQueen logra un efecto siniestro en las mujeres que viste pues las presenta como muñecas que son cualquier cosa menos hermosas. Mostrando la poca similitud de estos cuerpos vestidos con el de una mujer real, las modelos se muestran con figuras grotescas e imposibles. Lejos de ser bellas, demuestran que lo que la moda propone, el alcanzar la perfección y lo hermoso solamente da como resultado cuerpos deformes. Entonces, la pregunta que se da ante tal espectáculo es: ¿cuál imagen de la mujer es la real? ¿Será acaso ésta envuelta en vestimentas extrañas o la mujer real que aspira a esta imagen siniestra? Aquí se da un doble movimiento entre el objeto y el sujeto, entre lo animado y lo inanimado pues estas mujeres que desfilan no pueden ser reales vestidas de esa forma puesto que suponen un cuerpo que se adecua a esas ropas, y sin embargo, sí son mujeres, pero un espectáculo siniestro de la mujer (Placas 31, 31a, 31b, 31c, 31d, 31e y 31f). Por lo tanto, lo que se sugiere es que la modelo es simplemente una variante de una muñeca muerta y el proceso de fetichización hace posible la reubicación de los significados y de la mujer viva a la muñeca muerta.

La teoría del fetichismo, ya sea a partir de una comodidad o de un elemento sexual, se basa en el hecho de que haya un original, un objeto del deseo, orgánico desde donde los sentimientos son reubicados. La relación entre las modelos y los maniquíes ha puesto siempre en el centro de la cuestión la naturaleza del original, especialmente en casos donde las características de uno se mezclan con las del otro. ${ }^{133}$

En los siglos XVII y XVIII , el maniquí era la muñeca de las mujeres adultas en el sentido en que era vestido con las prendas de la alta moda proveniente de París. Luego de la Segunda Guerra Mundial el Sindicato Francés de la Moda creó el Teatro de la moda, una colección de maniquíes vestidos por las prendas de los grandes diseñadores parisinos y que recorrían el mundo promoviendo la moda francesa. La

${ }^{133}$ Para ahondar más sobre la cuestión del doble consultar: Shwartz, Hillel. La cultura de la copia: parecidos sorprendentes, facsímiles insólitos. Cátedra. Madrid, 1998. 
autora Susan Stewart en su libro On Longing: Narratives of the Miniature, the Gigantic, the Souvenir, the Collection describe como luego de la muerte del esposo de Catalina de Médici, ocho maniquíes vestidos con lujosísimas prendas fueron encontrados entre sus pertenencias. La autora también argumenta que el mundo de los objetos es una especie de constante presencia de los muertos entre nosotros y que el juguete es prueba de esto pues es a partir de éstos que lo inanimado retorna a la vida. ${ }^{134}$ Freud describe en su ensayo sobre lo siniestro que los niños esperan que sus muñecos cobren vida y esto no los asusta. Como ya se vio, lo que Freud hace en su ensayo es abrir la discusión de cómo lo siniestro se aparece a partir de la gran similitud que tienen las figuras de cera, las muñecas y los autómatas con seres vivos y viceversa. También, cuando Freud habla de lo siniestro, hace referencia al doble y a la dificultad de saber cuál es el original. Argumenta que el doble es siniestro pues es al mismo tiempo consuelo ante la amenaza de la muerte y la aniquilación y por otro lado es un desafío aterrador hacia la individualidad humana. Para explicar esto, hace referencia a su propia experiencia en un distrito rojo de un pueblo italiano del cual intenta salir pero vuelve una y otra vez, en lo que él llama "un retorno involuntario" y la presencia nuevamente de las mujeres pintarrajeadas. A pesar de la negación que hace Freud de la relación entre lo femenino y la muñecas, la figura siniestra a la que alude cuando menciona a las mujeres con las que se encuentra una y otra vez en esa experiencia, es la imagen a la que siempre se regresa y luego de varios ejemplos concluye con la sugerencia de que,

"Sucede con frecuencia que hombres neuróticos declaran que los genitales femeninos son para ellos un tanto siniestros. Pero esa

cosa siniestra es la puerta de entrada a una vieja morada de la criatura humana, al lugar en el cual cada uno de nosotros estuvo alojado alguna vez, la primera vez. Se suele decir jocosamente Liebe ist Heimweh

("amor es nostalgia»), y cuando alguien sueña con una localidad o con un paisaje, pensando en el sueño: «esto lo conozco, aquí ya estuve alguna vez», entonces la interpretación onírica está autorizada a reemplazar ese lugar por los genitales o por el vientre de la madre. De modo que también en este caso lo unheimlich es lo que otrora fue heimlich, lo hogareño, lo familiar desde mucho tiempo atrás. El prefijo

negativo «un-» («in-»), antepuesto a esta palabra, es, en cambio, el signo de la represión.”135

En el mundo capitalista, y en el mundo de la moda, pocos diseñadores comprendieron tan bien como McQueen que la modelo es el doble siniestro del maniquí y viceversa. Tanto en la colección La Pouppee y en It's Only a Game el doble siniestro que el diseñador recrea a partir de modelos con movimientos dislocados o como figuras de ajedrez se multiplica ad infinitum; y tal como en su colección para Givenchy de 1999

\footnotetext{
${ }^{134}$ Stewart, Susan. On Longing. Narratives of Miniature, the Giagantic, the Souvenir, the Collection. Duke University Press. London, 1993. Pp. 57.

${ }_{135}$ Freud, Sigmund. Lo siniestro (1919). Obras completas. Amorrortu Editores. Buenos Aires, 1991. Pp. 9.
} 
en la que usó maniquíes en lugar de modelos y en su otra colección titulada VOSS, la cual encerraba a las modelos en un cubo de espejos, el reflejo del doble siniestro se expandía hacia la infinidad como los maniquíes descritos en la novela de Zola.

Otro momento de la presencia de lo siniestro a partir del doble ${ }^{136}$ en la obra de McQueen es el uso de modelos gemelas en su colección titulada The Overlook (Placa 32) en donde se ve representado como la modelo hace alusión a los temas del doble y la muerte. El autor Mark Seltzer identifica a la modelo de la última parte del siglo XX con el trauma y la muerte, relacionando al doble siniestro la repetición del cuerpo de la modelo sobre la pasarela a la estructura misma del trauma y sus actos de repetición compulsiva. Seltzer lo dice así,

“...el cuerpo estilizado y expuesto de la modelo, una belleza tan generalizada que bien podría portar un código de barras; cuerpos en movimiento sin emociones que al mismo tiempo hechizan y están hechizados, ensimismados y vacíos o auto-evacuados. ${ }^{\text {137 }}$

Seltzer comenta como las prendas y el mundo de la moda reducen a la modelo a un objeto con connotaciones mortíferas, asimilando lo animado en lo inanimado. Tal como Benjamin lo dice,

"La moda está en conflicto con lo orgánico. Ella conecta el cuerpo vivo con el mundo inorgánico. En el viviente percibe su arte los derechos del cadáver. El fetichismo, que sucumbe al sex appeal de lo inorgánico, es su nervio vital." ${ }^{138}$

En la época en la que Seltzer defiende su argumento apoyado por lo expuesto por Benjamin, las modelos de los años noventa tenían un estilo de vida en el cual existía el abuso de drogas, desordenes alimenticios y una enorme presión para mantener su

\footnotetext{
${ }^{136}$ En los años que siguieron a la publicación del ensayo de lo siniestro, el interés sobre el tema decayó bastante pero al mismo tiempo se publicaron dos estudios importantes basados en este trabajo de Freud. El primero fue El doble de Otto Rank que apareció en forma de libro en 1925. En una nota al pie, Rank hace referencia al ensayo de Freud para consultar más al respecto sobre la ambivalencia del mecanismo del doble. El estudio de Rank es un clásico dentro del tema el doble, inclusive tal vez más que Freud. El segundo trabajo es menos conocido pero no menos importante, titulado El dios propio y extraño de 1923 escrito por Theodor Reik. Reik, junto con su esposa, asistieron a Freud en la investigación para el ensayo de lo siniestro. Este libro es una colección de ensayos relacionados con el lado oscuro y ambivalente de la religión. La primera parte se dedica al análisis de varios personajes de la fe cristiana como Jesús, María y Judas. Según Reik, la religión cristiana está basada de acuerdo a las reglas de la repetición y la compulsión. María y Jesús son imágenes espejadas de antiguas deidades reprimidas, las cuales parecen extrañas pero de hecho son familiares. María es interpretada como el doble de una antigua madre y diosa y Jesús, como su hijo y amante. Por su parte, Judas, el traidor, una de las figuras más siniestras en la historia del mundo, es interpretado a través del mecanismo de división del ego, también utilizado en el del doble. Este proceso explica la representación de Judas como el doble siniestro de Jesús pero de hecho son familiares. Además, afirma que la sensación siniestra que se experimenta es debido a los residuos de un miedo ancestral al demonio y el infierno es interpretado como el lado opuesto y siniestro del vientre materno. En la segunda parte, Reik examina por qué los dioses extraños, los rituales y los cultos, las religiones primitivas y las supersticiones le resultan siniestros a las personas "racionales" o ateas. Él dice que se debe al proceso de alienación, es decir, no solamente es el hecho de que la deidad nos recuerde un estado pasado del desarrollo religioso sino porque muchos rituales, como por ejemplo la circuncisión, nos recuerdan complejos infantiles.

${ }^{137}$ Seltzer, Mark. Serial Killer. Death and Life in America's Wound Culture. Routledge. Nueva York, 1998. Pp. 271.

${ }^{138}$ Bejamin, Walter. El libro de los pasajes. Ediciones Akal. Madrid, 2005. Pp. 42.
} 
extrema delgadez. Sin embargo, las características mortíferas de las modelos no se basan solamente en su presencia física sino también en esa producción en masa y en el concepto del doble en los cuerpos de las modelos al que se hizo referencia más arriba. Es decir, aquí el cadáver viene en relación a lo que Kristeva anuncia en su teoría de lo abyecto. En la pasarela y en especial en las colecciones de McQueen, el cadáver humano representado por la modelo es estetizado y moldeado. Los cuerpos de las modelos de la década de los noventa, vestidos con las prendas de McQueen.

Una de las colecciones de McQueen más interesante en este aspecto fue la de primavera-verano de 1999. En esta, el diseñador estaba interesado en explorar la relación entre la maquina y el cuerpo. La presentación comenzaba con la presencia de la atleta y modelo Aimee Mullins, de quien se habló a comienzos de este capítulo. Mullins abrió el espectáculo portando un par de piernas protésicas de madera labrada diseñadas por McQueen (Placas 33 y 33a). La misma colección cerró con la modelo Shalom Harlow quien apareció dando lentos giros sobre una plataforma como si fuera una muñeca de una caja musical al tiempo que su vestido blanco era rociado con pintura verde y negra por dos enormes brazos robotizados, yuxtaponiendo lo orgánico con lo inorgánico, es decir, una modelo que imitaba a una muñeca y dos máquinas haciendo movimientos humanos (Placas 34 y 34a). Esta colección sesga la relación entre el objeto y el sujeto evocado por el concepto de Marx del intercambio de comodidades en donde las personas y las cosas intercambian aspectos. Es en las figuras de estas dos modelos que los fantasmas de Marx parecen retornar y volver a vivir en el cuerpo de la alienación y los objetos fetichizados. Así, los orígenes históricos de estas colecciones se basan en los predicados de la modernidad, principios caracterizados -según desde lo que se desprende de la lectura de Marx- por ser desbordantes, animados e infinitamente productivos pero por otro lado, destructivos, voraces y crueles.

Elizabeth Wilson en su libro Adorned Dreams afirma que la moda y la modernidad comparten una cualidad doble pues ambas fueron formadas en el mismo momento y lugar, el de la ciudad capitalista temprana. ${ }^{139}$ En este sentido, la modelo podría ser un doble o un Doppelgänger capitalista, un tipo de fantasma corpóreo o un estilo de duelo encarnado que regresa a atormentar las relaciones de consumo. Las pasarelas de McQueen y su ropa aluden no solamente a la idea de lo femenino a través de la historia sino también a como ha sido visto como un espectáculo.

\footnotetext{
${ }^{139}$ Wilson, Elizabeth. Adorned in Dreams: Fashion and Modernity. Ed. Virago, Londres, 1985. Pp. 9.
} 
Los fantasmas de la Modernidad persiguen a la moda propuesta por McQueen y lo hacen regresando como un síntoma de histeria. Su trabajo se coloca siempre al límite entre lo experimental y la moda. El uso de maniquíes, de modelos duras y quietas o de máquinas imitando los movimientos humanos habla de una constante experimentación pero su maestría en el uso de telas y en resultado en las prendas habla de moda y de arte. Esta presencia de lo siniestro evoca el estatus alienado del trabajador capitalista y el ambiguo lugar de la mujer en el siglo XVIII tanto como sujeto y como objeto. (Recordemos el barómetro y su relación con la mujer). Tal como el flâneur encarna el alejamiento del observador nihilista y el trabajador industrial el distanciamiento que proviene del trabajo, la modelo que McQueen viste y reconstruye representa la ambivalencia siniestra de la mujer-objeto. De esta manera, el aislamiento que proviene del Modernismo retorna de forma reprimida en la moda y especialmente a través de la siniestra figura de la modelo-maniquí, o de la muñeca-mujer. El maquillaje y las prendas refuerzan esta idea y son parte fundamental de la presencia de lo siniestro. Vestidas con ropas extraordinarias que las constriñen en poses irreales; maquilladas de forma extraña para darles un aspecto duro y sin vida, la mujer es convertida en un objeto. Una similitud entre la belleza y la muerte se hace presente, es decir, entre los rituales de belleza como las cirugías plásticas y las dietas y los embalsamamientos y maquillajes funerarios.

Así, cuando Benjamin propuso en El libro de los pasajes que la moda a diferencia de la mujer viva, era tanto mortífera como irreproductiva, utilizó al maniquí como metáfora, diciendo que la mujer moderna que se alía a las innovaciones de la moda contra el proceso natural del deterioro reprime sus propios poderes reproductivos e imita al maniquí entrando a la historia como un objeto muerto. Cuando la moda fue mostrada por primera vez sobre mujeres, el término maniquí era usado para describirla a ella, y la palabra modelo se refería a la ropa. En este sentido, los análisis de Benjamin sobre la moda toman a la mujer como el emblema de la forma en que la moda es mortífera, espectral. Un tipo de fantasma dentro de la maquina capitalista. Benjamin identifica una cualidad mortal en la Modernidad misma, o el espectro en el centro del espectáculo. En estas relaciones, el término mortífero en Benjamin es discutido como una metáfora de la alienación, es decir, describe la muerte del espíritu en el capitalismo. No se trata, pues, del terror y la muerte inherente a la imagen de la femme fatale, sino de otro tipo de muerte, de aquella que sobreviene al distanciamiento inherente de la tecnología moderna. Benjamin habla del duelo por aquellas relaciones humanas pre-industriales que no eran mediadas por las 
comodidades. De esta forma, Benjamin describe a la moda como un intento de vencer o trascender a la muerte. La ropa imita la naturaleza orgánica (el uso de flores y plumas) mientras que el cuerpo humano vivo imita el mundo inorgánico (maquillajes con acabado natural, por ejemplo). Es justamente, este intercambio entre lo orgánico y lo inorgánico, lo vivo y lo muerto, lo que ha estado deambulando en la producción de Alexander McQueen y que hace posible la presencia de lo siniestro en su trabajo.

La construcción de la mujer en la moda es siniestra porque siempre se mantiene algo velado y nunca se sabe por completo la verdad. En 1997, se acuñó el término heroine chic para denominar el aspecto de las modelos en el mundo de la moda caracterizado por una piel pálida, ojeras y pómulos angulosos. Esta apariencia enferma se oponía a las imágenes del cuerpo saludable de las modelos de los ochenta. Ese cambio fue posible por diversas razones. La primera es que la heroína que comenzó a circular a finales de los noventa era mucho más pura y su precio era más accesible, llegando así a toda la clase media. El uso de la droga dejó de ser parte del mundo marginal y de la clase baja para filtrarse a la cultura y verse reflejado en películas y fotografías. Así, el look pasó rápidamente a influir en el maquillaje presentando a las modelos enfermas. Rebeca Arnold propone que el sexo, la muerte y la ambigüedad son los significantes claves de esa época. ${ }^{140}$ Así, mientras el cuerpo saludable de los ochenta era remplazado por el de los noventa en descomposición, se comienza a formular un espacio conceptual a partir del cuerpo de la mujer, en donde se da simultáneamente la perfección y el deterioro. Esta dicotomía era la imagen resultante de una violencia internalizada en el cuerpo femenino; es decir, en este camino de alcanzar el cuerpo perfecto para la moda, el cuerpo fue maltratado y destruido.

Pero más allá de la obvia relación del cuerpo abusado por la droga, la teórica de moda Katherine Wallerstein afirma que esta estética se veía más relacionada con lo abyecto y dice que este imaginario de cuerpos gastados y exhaustos tienen la connotación de la depresión que sobreviene luego de experiencias emocionales muy fuertes. ${ }^{141}$ Gilles Lipovetsky dice,

“...la euforia de la moda tiene como contrapartida el desamparo, la depresión y la confusión existencial. Hay más estímulos de todo género pero mayor inquietud de vida; hay más autonomía privada pero más crisis íntimas. Esta es la grandeza de la moda, que le permite al individuo remitirse más a sí mismo, y ésta es la miseria de la moda, que nos hace cada vez

\footnotetext{
${ }^{140}$ Arnold, Rebecca. Fashion, Desire and Anxiety: Image and Morality in the Twentieth Century. I.B. Tauris, Londres y Nueva York, 2001.

${ }^{141}$ Wallerstein, Katherine. Thinnes and Other Refusals in Contemporary Fashion Advertisements. Fashion Theory, Vol. 2. Junio, 1998. Pp. 129-150.
} 
más problemáticos para nosotros y para los demás."142

Con esta sombría descripción de la moda a finales del siglo $\mathrm{XX}$, es que Lipovetsky cierra su libro El imperio de lo efímero en donde argumenta que la moda ha contribuido de manera significativa al desarrollo de la sociedad moderna burocrática y democrática. Además dice que la moda prepara al individuo para los constantes cambios de la sociedad. Pero a pesar de esta mirada optimista, no deja de asombrar que Lipovetsky cierre con la cita anterior, en la cual se nota un sentimiento de duda y melancolía en el cual se puede distinguir la presencia de lo siniestro. Si bien el autor nunca habla de este concepto, la disonancia que él sí detecta en la moda -entre euforia y desesperanza- es la clásica dicotomía que se da en lo siniestro y que se dio en la moda de finales de los noventa y en especial en la de Alexander McQueen. Estas ropas van desde lo disfuncional, traumatizado y mortífero hasta cierta pesadumbre y alienación. Lipovetsky escribe que hay una especie de tragedia en la moda en la cual se pacifica el conflicto social pero al mismo tiempo se genera un malestar en cuanto a la vida. Es esa angustia y sentimiento de extrañeza lo que sobreviene como lo siniestro.

De esta manera, el cuerpo maltratado al que hacía referencia Rebecca Arnold es el que caracteriza a la moda de los noventa. Este era un cuerpo con signos de violencia y trauma y éste era el que McQueen vestía. Fue durante los noventa que la violencia y la enfermedad se vieron envueltas en el glamour de la moda denotando la necesidad siniestra de controlar el caos de la vida cotidiana a partir de la violencia. Esto tuvo eco también en el mundo del arte. El artista Marcus Harvey creó en 1995 el retrato de la asesina de niños Myra Hindley (Placa 35). Esta obra monocromática en óleo está formada por miles de huellas de manos de niños simulando el efecto de impresión por puntos de las fotografías en periódicos dando como resultado la imagen del rostro de Hindley. En el 2001, la exposición itinerante Trauma reunió el trabajo de varios artistas cuyo trabajo estaba interesado en la experiencia de eventos traumáticos.

El significado original de la palabra trauma era herida y tiene un uso médico al mismo tiempo que psicoanalítico. Sin embargo, a finales de los noventa, el término también comenzó a ser usado para describir un estado psíquico y/o emocional de shock tan grande que llegaba a provocar una especie de dislocamiento. Es en este sentido en el que se ubica la ropa de McQueen, es decir, una moda cuyo imaginario y diseño es perturbador. La moda de McQueen ha sido frecuentemente construida como algo

142 Lipovetsky, Gilles. El imperio de lo efímero: La moda y su destino en las sociedades modernas. Ed. Anagrama, Barcelona, 2009. Pp. 324. 
patológico, es decir, que el cuerpo que viste es aquel marcado por algún tipo de trauma y muchos de los temas que desarrolló se volvieron cada vez más oscuros e incluían-como ya se ha mencionado- a la muerte, la enfermedad y el deterioro. Además, el campo de trabajo de las representaciones del cuerpo traumatizado también dio lugar a la creación de imágenes de transformación en donde si bien el cuerpo podía estar maltratado, también estaba abierto para especulaciones críticas y constructivas.

La idea de que tales temas pudieran ser considerados por la moda era impensable antes de la década de los noventa, sin embargo, un grupo de diseñadores comenzó a trabajarlos a finales de dicho momento. Aquellos diseñadores como Alexander McQueen que tenían y buscaban espacio dentro de su producción para experimentar a pesar de no recibir dinero por los productos que generaban. McQueen consideraba que las prendas debían expresar sentimientos aun cuando éstos fueran miserables. Diseñadores como él, pensaban que era bueno bajar la velocidad acostumbrada de las pasarelas y darles la oportunidad a las personas de observar detenidamente y reflexionar sobre las prendas. Los aspectos siniestros de las prendas de McQueen fueron diseñados para lograr tácticas de shock dirigidas a romper con las convenciones clásicas del cuerpo tanto en el arte como en la moda. Hal Foster argumentó que para muchas personas en la década de los noventa la verdad residía en el sujeto traumatizado o abyecto, es decir, el cuerpo descartado y dañado. Dice así,

"Si hay un sujeto de la historia de la cultura de la abyección en lo absoluto no es el Trabajador, la Mujer o la Persona de Color sino el Cadáver." ${ }^{143}$

En muchas de las colecciones de McQueen se utilizó la idea del interior del cuerpo para acercarse a temas oscuros y relacionados con la muerte, tratando de reinstaurar la categoría del memento mori en la práctica contemporánea de la ropa. McQueen volvía de cierta forma al imaginario de los primeros anatomistas; además, sus ropas sugerían imágenes en donde el cuerpo era en sí mismo una cripta, es decir, una manera de incorporación melancólica del trauma en el cuerpo. Este tema lo explican muy bien los psicoanalistas Nicholas Abraham y Maria Torok argumentando que el duelo que no es capaz de expresarse erige una especie de tumba secreta al interior del sujeto, enterrando viva a la pérdida dentro de la cripta como si ésta fuera una persona completa, con todo y su propia topografía, añadiendo que la cripta además

${ }^{143}$ Foster, Hal. El retorno de lo real. La vanguardia a finales de siglo. Ediciones Akal. Madrid, 2001. Pp.170. 
incluye un trauma supuesto o verdadero. ${ }^{144}$ Así, cuando McQueen, en las colecciones ya presentadas, utiliza el imaginario del interior del cuerpo -ya sea un adentro emocional o físico- lo que sugería es la idea de un cuerpo como cripta o tumba psíquica, el cual estaba extravagantemente ataviado. Estas imágenes que se creaban trabajan con la iconografía de la muerte y el interior del cuerpo para poder hablar de un mundo interior escondido y que retornaba o que se asomaba provocando lo siniestro. En este sentido, la moda puede llevar al espectador al interior, ya sea emocional o corporal.

Charles Dana Gibson, el ilustrador que a comienzos del siglo XX creo a la chica Gibson, epítome de la modernidad y de la vida, también creó un memento mori en la imagen de una mujer vestida y mirándose al espejo de un tocador y cuya imagen se convierte en la figura de un cráneo (Placa 36). A la distancia, la imagen devuelve la forma de un cráneo y es sólo luego de mirarla con detenimiento que se revela la otra versión en donde una mujer se acicala. Así se confirma la noción de que la muerte y el deterioro eran temas privilegiados ante la belleza y la juventud que son simplemente elementos inestables. Esta representación de Gibson no es nueva. Ya muchos artistas en el siglo XVII mostraban a mujeres con símbolos de la efímera bella y cráneos, formando las famosas vanitas. Por otra parte, toda la moda siempre tuvo que ver de manera estructural con el memento mori, aún cuando la muerte misma no está representada de ninguna forma. En los noventa, cierto tipo de moda $-y$ en el cual se encuentra McQueen- estaba permeada por referencias explícitas a la muerte. McQueen fue el principal exponente del uso de la calavera como el contenido melancólico debajo de la piel. Al mismo tiempo, otra parte de la moda se aferraba a los cuerpos sanos y llenos de vida. Los dos tipos de imaginario co-existían en distintos ámbitos. Igual que en el trabajo de Gibson.

McQueen utilizó una serie de elementos visuales de la tradición del memento mori como el cabello humano, los huesos y lo putrefacto. Para su colección de primaveraverano de 1998 uno de los accesorios más impresionantes fue el que portaba una modelo sobre un vestido negro. Un corsette de aluminio en forma de costillar diseñado en exclusivo por el joyero Shaun Leane y que fue moldeado de un esqueleto humano

\footnotetext{
${ }^{144}$ Abraham y Torok veían al síntoma como un tipo de huella o memoria rastreable del trauma. Además estaban interesados en el lenguaje como un sistema de rastros expresivos y con su trabajo sobre el trauma concibieron una serie de metáforas corporales para describir cómo sus pacientes podían trascender o superar traumas que les servían como obstáculos para su propio funcionamiento. Estaban interesados en las formas en las que las personas guardan o sellan el trauma, utilizando la metáfora de la cripta y de la incorporación para explicar la creación individual de una tumba psíquica. Para más sobre el tema consultar: Abraham, Nicholas. Torok, Maria. La corteza y el núcleo. Amorrortu Editores. España, 2005.
} 
real (Placa 37). Además, la colección también incluía tocados para la cabeza confeccionados con cabello humano.

En el arte contemporáneo el tema de la muerte también surgió y fue elaborado por artistas como Damien Hirst y sus esculturas de animales muertos preservados en formol, o la obra de Marc Quinn titulada Cabeza y que estaba moldeada a partir de cuatro litros de su propia sangre que mantuvo refrigerada.

Antes de la llegada de la medicina moderna y sus nuevas tecnologías para explorar el cuerpo, el interior del cuerpo siempre estaba relacionado con la muerte. Hoy en día a pesar de los avances médicos, esta connotación todavía se mantiene y un encuentro visual con el interior del cuerpo es muchas veces relacionado con la enfermedad y las patologías. Además de esta relación con la muerte, el interior del cuerpo se ha relacionado particularmente con la mujer dentro de la tradición Judeo-Cristiana. El autor Jonathan Sawday en su libro titulado The Body Emblazoned argumenta en su historia de la anatomía que en la cultura occidental las entrañas del cuerpo son un tipo de cabeza de Medusa ${ }^{145}$ que habla de nuestra propia mortalidad y que sin importar el género, el interior siempre es primero feminizado y luego sexualizado en la representación. Es decir, es el cuerpo de la mujer con sus partes internas y externas el que representa un espacio de peligro, deseo y miedos inconscientes relacionados con la muerte y la sexualidad. ${ }^{146}$ Ya en el primer capítulo se presentó el caso del barómetro el cual era el intento masculino de controlar el cuerpo de la mujer planteando la premisa de que el instrumento era capaz de detectar los estados de ánimo femeninos.

El uso de McQueen de esqueletos y de calaveras habla de la conexión histórica entre el sexo, la muerte y la mujer (Placa 38). Así, muchas de sus ropas sugieren un gusto por el imaginario que se desprende de la muerte, la descomposición y esa dualidad característica de lo siniestro (interior/exterior, vida/muerte, salud/enfermedad), tal vez

\footnotetext{
${ }^{145}$ Freud continuó analizando los restos de aquella fase primitiva dentro del desarrollo humano en los temas literarios así como en la vida diaria. Muchos de éstos aparecen nuevamente en el texto de lo siniestro como supersticiones, premoniciones, repeticiones extrañas y coincidencias, el mal de ojo, el doble, el Gettatore y la repentina animación de objetos sin vida. Este movimiento circular de vida y muerte y la ambivalencia del deseo y la muerte relacionada con la madre estará presente en lo siniestro en relación a la percepción que se tendrá de los genitales femeninos. El tabú de la virginidad y La cabeza de Medusa son los textos de Freud en los que se habla sobre motivos literarios y mitología en donde se analiza la vida y la muerte, la desfloración en las culturas primitivas en donde la virginidad produce miedo y atracción, la castración y su posterior protección en contra por medio de la multiplicación de falos representada por la cabeza de la medusa, además de que ésta representa también los genitales femeninos, los cuales en el ensayo de lo siniestro evocan miedo. En general todos hablan de los mecanismos de defensa que se ponen a trabajar durante el desarrollo infantil y el retorno de lo reprimido.

${ }^{146}$ Sawday, Jonathan. The Body Emblazoned: Dissection and the Human Body in Renaissance Culture. Ed. Routledge. London, 1995. Pp. 13-14.
} 
como una forma de superar la angustia de la existencia y de explorar los estratos más oscuros y execrables del ser humano. La fascinación de la moda de McQueen con el lado más siniestro de la vida es la otra cara del mundo de la moda y su interés por los cuerpos idealizados. Así, todas esas normas y estereotipos son solamente una parte de la realidad de este mundo y el diseñador se veía fuertemente atraído por esa otra parte olvidada y rechazada. El trabajo de McQueen funciona, por lo tanto, como un síntoma para evocar los opuestos en donde, por mencionar sólo un ejemplo, el glamur esconde sutilmente al deterioro, el cual retorna luego como algo reprimido generando lo siniestro. Es de esta forma que finalmente se llega a lo planteado en esta tesis. Un largo recorrido que permitió comprender en qué sentido podía encontrarse lo siniestro en ropas que a primera instancia pueden hablar de muchas cosas. Ese es el encanto del concepto de lo siniestro, que éste permanece escondido pero asoma su rostro de vez en cuando para generar una sensación que oscila entre el malestar, la confusión y el goce.

Tal como en el cuadro de 1529 del artista Lucas Furtenagel (Placa 39) -en el cual retrata al pintor Hans Burgkmair y su esposa Anna, el espejo (símbolo por excelencia de la vanidad femenina) revela la muerte a los vivos, las prendas de McQueen tienen a la muerte como el centro de la vida, la descomposición como corolario de la perfección de la juventud y la oscuridad como la inevitable consecuencia de la luz. Lo siniestro en todo su esplendor, si es que puede hacerse referencia a él así.

Con el regreso del memento mori y las imágenes de las vanitas, la segunda mitad de la década de los noventa se vio invadida por el universo del siglo XVIII. Los espectros, el mundo interior de los seres humanos, la imaginación, los sueños, las máscaras que escondían a las personas y las consecuencias de esto, se ve replicado de distinta forma en los noventa: una época de globalización y tecnología que avanza a velocidades vertiginosas. Tal vez, sea por esto, y por las semejanzas con lo presentado sobre una parte del siglo XVIII, lo que hace que autores y artistas como McQueen se interesen por lo abyecto, el trauma ${ }^{147}$ y la angustia. ${ }^{148}$

\footnotetext{
${ }^{147}$ A través de los sueños y de la repetición del trauma de manera controlada, el ego trata de activamente prepararse para futuros eventos traumáticos y para conciliarse con el pasado. La ansiedad de castración y el miedo concomitante a perder el amor son las primeras represiones de una situación traumática pues reproducen la impotencia del nacimiento. Ya que el recién nacido está indefenso y no puede hacer nada ante la amenaza de perder su objeto preciado. Freud se preguntó si la ansiedad a la castración sería análoga al miedo mortal que tiene un papel tan importante en la neurosis traumática. Ante una experiencia en donde la vida se puso en peligro de muerte, el ego se siente abandonado por Dios (la versión adulta del padre de la niñez que protege) y por lo tanto desamparado. La experiencia del nacimiento puede ser pensada más o menos por las mismas líneas pues el acto de nacer puede ser descrito en términos de separación de la madre. Además, el niño varón narcisistamente se identifica con el pene pues lo entiende como un instrumento por el cual será capaz de volver al vientre (por medio del acto sexual). Desde este punto de vista, la sensación de lo siniestro que despiertan los genitales
} 


\section{Accesorios de la fragmentación}

En este sentido, los accesorios en la producción de Alexander McQueen son parte importantísima para subrayar lo mencionado hasta el momento. Si la superficie pulida del maquillaje convencional y los accesorios constituyen un tipo de caparazón que mantiene alejado el horror que provoca la muerte y el declive, los adentros del cuerpo son la contracara de esa negación. Cuando McQueen hace uso de ciertos accesorios no convencionales, el cuerpo traumatizado de la moda dejó de ser una cripta cerrada, en el sentido en que los Abraham y Torak lo comprendían. De esta forma, McQueen lograba abrir esa tumba en una forma creativa a partir de sus trabajos. Es decir, tal como el cuerpo puede ser representado como un sepulcro, también esto mismo puede hacerse con los espacios alrededor y entre él, y revelarlo de forma creativa.

En el tema del trauma, Torok y Abraham también trabajaron sobre el concepto de la auto-creación y sexualidad argumentando que si el trauma no es resuelto éste entorpece el moldeado creativo del ser del cual la sexualidad es una parte fundamental. La introyección puede implicar la proyección del trauma hacia el ser como una especie de pantalla protectora. Por más doloroso que esto pueda resultar es preferible a incorporar el trauma al ser y sellarlo como un secreto. Los autores argumentan que la muerte erótica puede ser parte del proceso de introyección, por lo tanto un evento traumático que no logra ser acomodado, será incorporado transformando al cuerpo en una tumba con un ser viviente en el interior. Pero si el sujeto es capaz de dirigirse al evento traumático a través del proceso de introyección, entonces podrá avanzar y reconstruir su ser. ${ }^{149}$

De esta manera, el cuerpo traumatizado de la década de los noventa puede ser aún analizado por medio de esta metáfora de incorporación a través de muchos de los

femeninos no se debe tanto al miedo de castración de perder el pene sino también a la frustración fantasmal o deseo de regresar a la vida uterina.

${ }^{148}$ En la segunda teoría sobre la ansiedad que Freud maneja, plantea que ya no es necesario distinguir entre la real y la neurótica pues ambas son reacciones ante el peligro. Lo única distinción que ahora importará es la de saber si el peligro es externo o interno. De esta manera, la ansiedad ya no es el producto de la represión sino el motor que la echa a andar, es decir, el ego responderá a los impulsos de la misma forma que si fueran peligros externos. La razón por la que el ego responde a las señales de peligro activando el mecanismo de represión tiene que ver con la repetición y la represión primaria. Si en la primera teoría Freud plantea que la ansiedad es la repetición del acto de nacer, es a partir de 1926 y en adelante que calificará esa experiencia como trauma o la primera represión. Los traumas, a diferencia de los peligros comunes, son confrontaciones inesperadas con peligros mortales. Su naturaleza es tan característica pues son derivadas de la completa indefensión del ego. Esto es la base de la reactivación de la ansiedad en situaciones similares.

${ }^{149}$ Abraham, Nicholas. Torok, Maria. La corteza y el núcleo. Amorrortu Editores. España, 2005. Pp. 102104. El término de introyección es usado por estos autores de manera distinta a otros psicoanalistas y refiere a lo opuesto a incorporar. Sin embargo, la metáfora sugiere la noción de un ser interior que puede ser usado para pensar sobre la relación entre el cuerpo y la identidad. 
accesorios/joyería diseñados por encargo de Alexander McQueen para sus colecciones. La joyería tiene una relación muy especial con el cuerpo y el diseñador lo sabía. El joyero por excelencia de McQueen fue Shaun Lean y fue éste artista quien supo reflejar la elegante crueldad y la delicada presencia de lo siniestro de las prendas del diseñador. Uno de estos accesorios es el aplique para boca que rodea la cabeza para volver al frente con dos grandes púas (Placa 40) evocando aquello que de la mujer aterra, es decir, un tipo de belleza decadente y delicada. Otro accesorios, diseñado por Sarah Harmanee para McQueen, es una pieza para la cabeza adornado con cuchillos (Placa 41). Labrado como si estuviera bordado con fino encaje, sobresale por uno de los lados del rostro de la mujer, amenazante a cualquiera que se acerque. Dai Rees, también colaboró con el diseñador en los apliques de cuernos y osamentas de animales sobre las prendas (Placas 42 y $42 a$ ) logrando así reconfigurar los accesorios ya no para colocar a la mujer como un sujeto delicado y adornado dulcemente, sino como una fiera agresiva y siniestra.

Otro de los joyeros que siempre trabajaron con McQueen fue Simon Constin quien trabaja con las pieles, huesos y cadáveres de animales. Usando también fluidos humanos una de sus piezas más controversiales fue un collar que portaba tres pequeñas botellas con líquido seminal y en una placa la leyenda de vicio $y$ virtud recordando la atracción entre opuestos: belleza y horror, sexo y muerte (Placa 43).

Tal como Phillipe Ariès y Norbert Elias relacionaron la dans macabre del siglo XIV con las plagas de ese momento, Julia Kristeva encuentra conexiones entre el regreso de las imágenes de la putrefacción corporal y la angustia a finales del siglo XX con el VIH y el SIDA. Son trabajos como los de Constin los que hablan del miedo a los fluidos corporales que se venía arrastrando de los años ochenta debido a su enorme relación con el virus del SIDA. El semen, asociado casi siempre con el placer y el comienzo de la vida también era ahora, mortal y tóxico. El uso de los accesorios de estos joyeros en las colecciones de McQueen, subrayaba las dicotomías que le interesaban: la vida y la muerte. Un memento mori contemporáneo intrínsecamente unido al sentimiento de lo siniestro.

Cuando Alexander McQueen empapó a sus modelos con lluvias doradas (agua iluminada con luces amarillas) mientras caminaban en la pasarela, lo que el diseñador hacía era ejemplificar la forma en la que el trauma -que hasta ahora se ocultaba en una cripta- se convertía en espectáculo a través de una puesta en escena de la transgresión. Como ya se ha visto, las pasarelas del diseñador demostraban su 
fascinación con lo artificial, el drama, el espectáculo, la transformación y el horror generado por la presencia de lo siniestro en todas sus prendas y accesorios. Estas escenificaciones lograban que lo reprimido retornase, que aquella cripta se abriese y dejara el trauma fluir de forma pública en lo que Mark Seltzer denominó como la cultura de la herida. El autor argumenta que la fascinación que se tiene por los cuerpos heridos y traumatizados en el cine, las novelas y los medios se debe al colapso de las diferencias entre lo público y lo privado, a tal punto en que la esfera pública se ha vuelto patológica. ${ }^{150}$ Además, Seltzer conecta la presentación clásica de la pasarela, es decir, el cuerpo de las modelos que andan una y otra vez por el mismo lugar, con el la repetición compulsiva del trauma. En las presentaciones de McQueen aunque lleno de aspectos de lo siniestro, el cuerpo que viste parece intentar salir de la repetición del trauma por medio del proceso de reificación. El cuerpo que porta las ropas de McQueen está protegido a través de ese glamour extraño que porta, convirtiéndolo en un feroz fetiche o en un amuleto pues si el fetiche es un objeto, siempre lo es pero de naturaleza muy poderosa, tal como la cabeza de la Medusa. Aún cuando el glamur se ve ensombrecido por lo siniestro oscilando entre la belleza y el horror, tales contradicciones asisten a la presencia de lo ominoso que se convierte en la principal fuerza de atracción de estas prendas.

Como ya lo mencioné, en la colección titulada The Hunger, el diseñador presentó a una modelo vestida con un corsette transparente que dejaba ver lombrices vivas y tierra entre el material y el cuerpo de la mujer (placa 15). Las lombrices utilizadas tienen en cierto sentido, el mismo color y forma que los intestinos y combinan perfectamente con los colores de las ropas. Además, los cortes punzantes del acabado del saco funcionan como cortadas de bisturí sobre la piel de la modelo y dejando al descubierto su interior. Este corsette hace alusión a las Transi o tumbas cadáver del siglo XV, esculturas mortuorias que representaban un cadáver en descomposición y en las cuales en algunas ocasiones era posible ver gusanos comiendo los intestinos. El disgusto visceral que estas esculturas pueden evocar se encuentra en oposición directa a la idealización y el glamur de la moda de finales del siglo XX. Pero, a pesar de tales connotaciones, la siniestra fuerza de esta prenda de McQueen como un tipo de Transi moderno reafirma el derecho de los vivos de controlar la iconografía de los muertos. El saco se usa de tal forma que parece representar la piel cuando es retirada del torso durante una operación o autopsia. Las lombrices pueden evocar la tumba pero el corsette de plástico enmarca agresivamente

${ }^{150}$ Seltzer, Mark. Serial Killer. Death and Life in America's Wound Culture. Routledge. Nueva York, 1998. Pp. 254. 
los senos de la modelo, logrando la presencia de lo siniestro al superponer opuestos. Esta prenda habla de una especie de profanación más que de la muerte misma y reafirma el placer que se obtiene cuando se presencia lo siniestro en un momento de transgresión y extrañeza. Las prendas de McQueen evocan ese placer perverso y transgresor que es parte de la contemplación de lo siniestro y que se logra al unir opuestos como la sexualidad, la muerte, el asco y el deseo.

La oscilación entre los opuestos se caracteriza en psicoanálisis como desdoblamiento o fragmentación. Hal Foster lo identifica como un desdoblamiento moral:

"Una escisión moral, la paradoja del disgusto rebajada por la fascinación o de la simpatía rebajada por el sadismo; y una escisión de la imagen corporal, el éxtasis de la dispersión rescatada por el blindaje, o la fantasía de la desincorporación disipada por la abyección."

Para Foster el ser moderno o postmoderno estaba constituido precisamente en y a través de tal desdoblamiento repetido, en donde el ser está constantemente haciéndose y deshaciéndose, como la muñeca de Bellmer que inspiró la colección titulada La Poupée. Esta constante repetición es una característica también del trauma. La oscilación entre opuestos que Foster identifica como lo que tipificaba los intereses intelectuales de los artistas de los años noventa, constituía el autentico enigma del sujeto ${ }^{152}$, y aunque Foster no se interesó por la moda, dónde mejor que en la inestable compulsión de la moda para localizar esto.

Estas prendas que van de lo deseable a lo repulsivo en un devenir poco estable hacen que lo siniestro sea lo central en ellas. Sin embargo, el que contengan poco equilibrio y jueguen entre opuestos no quiere decir que sean siniestras todo el tiempo -pues parte de las características principales de este concepto es que para que se dé debe de aparecer y desaparecer- aun cuando su presencia se evoque directamente pues sus características no son nunca estables. Lo siniestro se observa en la oscuridad y en la presencia de la luz, en el pasado y en su retorno a lo presente. Es como el imaginario que produce la alegoría barroca de Benjamin en donde, por ejemplo, un arpa se transforma en el hacha de un verdugo,

“...el salón del trono se transforma en calabozo, el lugar del placer en cripta funeraria y la corona en una guirnalda de ensangrentado ciprés."153

De igual forma, la ropa de McQueen transforma huesos y armas en elaborada joyería, pelo y fluidos orgánicos en tocados y collares como recordatorios melancólicos de la

\footnotetext{
${ }^{151}$ Foster, Hal. El retorno de lo real. La vanguardia a finales de siglo. Ediciones Akal. Madrid, 2001. Pp. 227.

${ }^{152}$ Ibid. Pp. 228.

${ }^{153}$ Benjamin, Walter. El origen del drama barroco alemán. Ed. Taurus. Madrid, 1990. Pp. 81.
} 
incertidumbre de la vida pero también como elementos atractivos, ornamentales y de lujo que comparte con lo barroco su gusto por lo extraño y las creaciones fantásticas.

La inestabilidad de las imágenes producidas por las ropas de McQueen es una noción moderna también. Buci-Glucksmann argumenta que tener al cadáver dentro de uno mismo destruye la certeza del sujeto. ${ }^{154}$ Así, mientras que la producción del diseñador se remonta a una parte de la estética barroca también es singularmente moderna, precisamente en la forma en la que ubica al cadáver en el centro del ser y de su propuesta artística. Convirtiendo la vida en muerte, la luz en oscuridad y el placer en trauma, y viceversa, se rompe la idea de que estas nociones sean opuestas sino parte de un entorno que se devela siniestro por permitir la existencia de ambos al mismo tiempo, un reino mágico en el que nada es lo que parece. Sin embargo, no debe olvidarse que hay un precio que pagar por presenciar lo siniestro en ese constante devenir de extremos. Este precio es que nunca podremos vivir no siendo conscientes de nosotros mismos de forma desenfadada y natural en el presente, sino que estamos destinados a oscilar incansablemente entre diferentes tiempos e ideas. Además, estaremos todo el tiempo viviendo el retorno de lo reprimido o de lo que se pensó estaba en el pasado dándonos una sensación siniestra cada vez que estos fragmentos vuelven. Así estamos condenados a repetir y balancearnos entre instancias para poder comprender las cosas que nos rodean por medio de las referencias cruzadas en tiempo y en espacio. Pero este movimiento de ir y venir imita la estructura del trauma, estructura psíquica enraizada en la repetición compulsiva que sirve como método para bloquear los recuerdos de un evento problemático. Además, esta fluctuación patológica entre opuestos hace que lo siniestro se presente cuando ya no se es posible identificar las diferencias, y una cosa se puede convertir en su opuesto de forma permanente, dejándonos ante la incógnita de si estamos ante el original o su doble siniestro.

Alexander McQueen formó un eje bastante claro en sus creaciones en las cuales combinó lo teatral, lo suntuoso y lo siniestro. Tal fue su sello estético. Es claro que el diseñador tuvo una particular predilección por lo extraño y diferente, por borrar los límites entre lo real y la angustia que genera el alejamiento de esta.

McQueen creó mundos de ensueño aterradores, violentos y salvajes a partir de la moda. Tomó el mundo de las pesadillas y de los fantasmas en un intento de

\footnotetext{
${ }^{154}$ Buci-Glucksmann, Christine. Baroque Reason: The Aesthetics of Modernity. Ed. Sage. Londres, 1994.
} Pp. 76-103. 
domesticarlos y presentarlos ante el espectador como algo retornado de tiempos pasados y develando una realidad insuperable: los seres humanos aún podemos ser aterrorizados por nuestra propia naturaleza. 


\section{Conclusiones}

La presente tesis tuvo como objetivo evidenciar la presencia del concepto de lo siniestro a través de una metodología basada en un analisis cualitativo e interpretativo de la obra del diseñador inglés Alexander McQueen. Esto quiere decir que se consideró y se observó al trabajo de éste como generador de significaciones e interpretaciones desde sus signos plásticos, probando que las prendas están constituidas por distintos elementos tanto lingüísticos como icónicos que construyen e integran un discurso específico.

Para constatar esto se buscó primero definir un lenguaje y una metodología que fueran lo más adecuados posibles al objeto de estudio. El empleo del psicoanalisis como fuente generadora del término mismo, resultó ser la indicada para encontrar conexiones que expliquen su presencia en la obra. Por medio de la presentación del trabajo de distintos autores fue posible notar como lo siniestro es capaz de ofrecer una serie de parámetros que pueden ser aplicados al analisis de obras. Si antes el concepto ya había sido utilizado en la literatura, el cine y las artes, con esta tesis se comprobó que la moda es un campo fértil para su desarrollo y posterior reflexión estética. Dado que lo siniestro se da en ciertas situaciones y circunstancias, el haberlo encontrado en la moda ayudó a captar su sentido mostrando que se presenta como algo latente que se expande sin control llegando a provocar terror.

Así, en cuanto que lo siniestro es una experiencia humana resulta posible plantear desde allí un acercamiento a una de las manifestaciones culturales más cercanas al hombre como es la vestimenta y desprender las consecuencias de su presencia. Esto permitió releer las prendas bajo una perspectiva diferente y formular nuevas configuraciones. Se pudo observar la importancia de la infinidad de circunstancias de diverso orden que confluyen para transformar los horizontes de interpretación de una prenda. Se estableció que lo siniestro puede ser tambien un efecto voluntario, es decir, algo que se produce y se estimula de antemano. La aplicación del término a la obra de McQueen demostró que la expresión artística puede ser de gran calidad y con formas bellas pero al mismo tiempo con la ambigüedad que remite a la presencia de lo siniestro. En ese sentido podemos afirmar que lo siniestro resulta un elemento constitutivo de la poética de este creador.

En efecto, McQueen hizo ropa extraordinaria pero angustiante. Los fantasmas del pasado y el retorno de aquello que se pensaba superado coloca al espectador de sus prendas bajo el tétrico manto de un sentimiento que es dificil de explicar pero que se 
reconoce inmediatamente al experimentarlo. Los motivos cadavéricos de muchas de sus piezas, la exaltación de la femme fatale, la inminencia de la muerte en la vida diaria y la repeticion de dobles legitiman la existencia del concepto freudiano en sus colecciones. La fascinacion ante sus ropas y el terror que la mayoría produce no hace más que enfatizar la ambigüedad característica de lo siniestro: aquello que no es pero que al no ser, es. Siempre ausente, siempre presente, como un espectro mirando desde una esquina oscura.

Al final, es posible pensar en el tema de la moda y lo siniestro como una nueva serie de experiencias estéticas dignas de análisis y que debido a su conexión con la creación humana se mantienen siempre abiertas a nuevas interpretaciones y aportes que revelen más sobre el tema. Ya el simple hecho de detenerse ante la particularidad del término y aplicarlo al campo de la creacion de la moda abre paso a una investigación que va mas allá de lo propuesto en esta tesis.

Por todo lo dicho, en esta tesis se pretende haber mostrado que:

1) El estudio estético sobre la obra de McQueen supone un enfoque multidisciplinario donde convergen la psicología, la historia, la sociología, la filosofía, la economía, entre otras.

2) Este estudio también puede significar un aporte relevante para todas aquellas disciplinas involucradas.

3) La categoría de lo siniestro -tomada de la psicología pero que como se vio tiene una amplia trayectoria en las ciencias sociales y en el arte- resulta pertinente para comprender la densidad estética, psicológica y aún política (en cuanto es posible encontrar una suerte de alusión a cierta ferocidad de la sociedad de consumo, al abuso de los cuerpos o de las imágenes) de la obra de Alexander McQueen. En ese sentido resulta posible afirmar que estamos ante una poética de lo siniestro.

4) La ambigüedad y las tensiones entre lo superficial y lo profundo, lo manifiesto y lo latente, lo pasado y lo presente, propios del lenguaje del artista, convierten a su obra en un discurso ficcional, en un enigma cuyo intento de develación ayuda a la autocomprensión de aspectos poco frecuentados de la experiencia contemporánea. 
Ante este escenario, la presente tesis aspira a sumarse al trabajo que existe actualmente sobre la moda y a aportar un enfoque nuevo de análisis teórico, estético y crítico sobre el tema y sus contextos.

Queda claro que esta investigación no cierra su tema de estudio sino que pretende que otras investigaciones encuentren un punto de partida para continuar con la aplicación de lo siniestro en la misma disciplina o en otras, de modo que esta categoría pueda ocupar el lugar de relevancia teórica que por mucho tiempo parece no habérsele dado. Al mismo tiempo espero haber mostrado que la reflexión sobre la producción de Alexander McQueen es aún un campo abierto a una multiplicidad de lecturas, al que esta tesis pretende haber contribuido a enriquecer. 


\section{PLACAS}




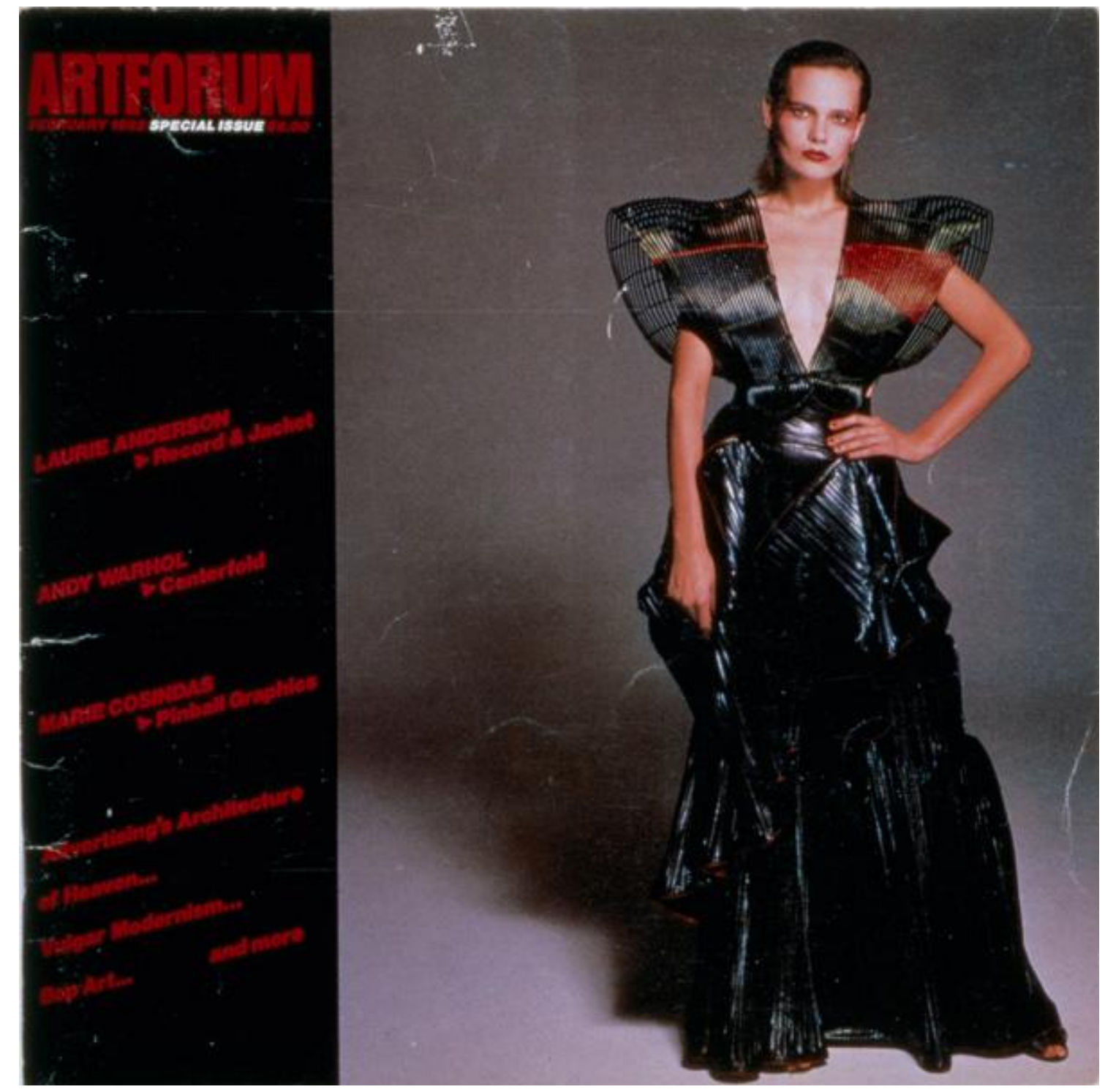

Placa 1. Revista ARTFORUM Nueva York, Febrero, 1982. 


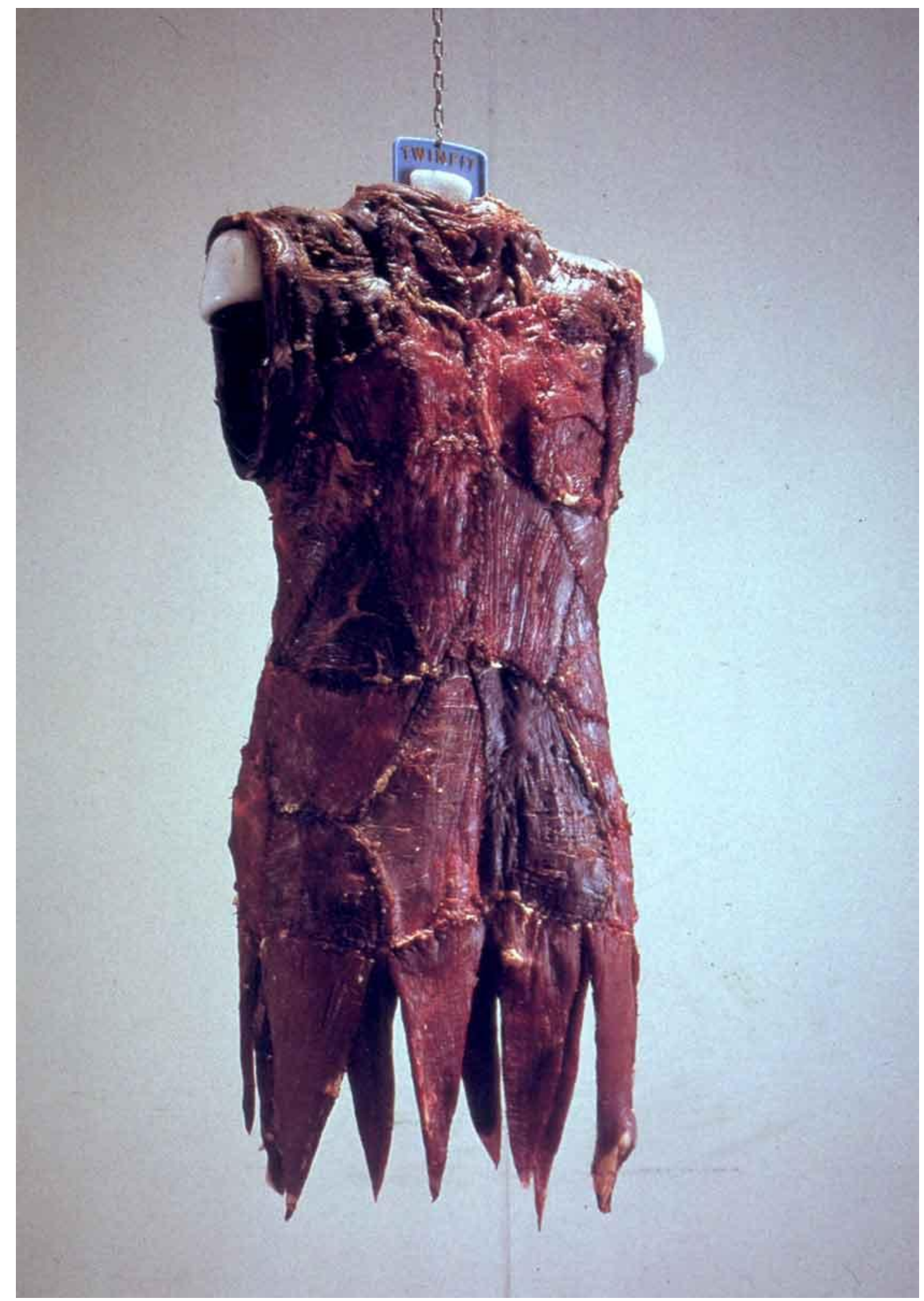

Placa 2. Jana Sterbak, Vanitas - Flesh Dress For An Albino Anorexic, 1987 Galería Toni Tàpies 


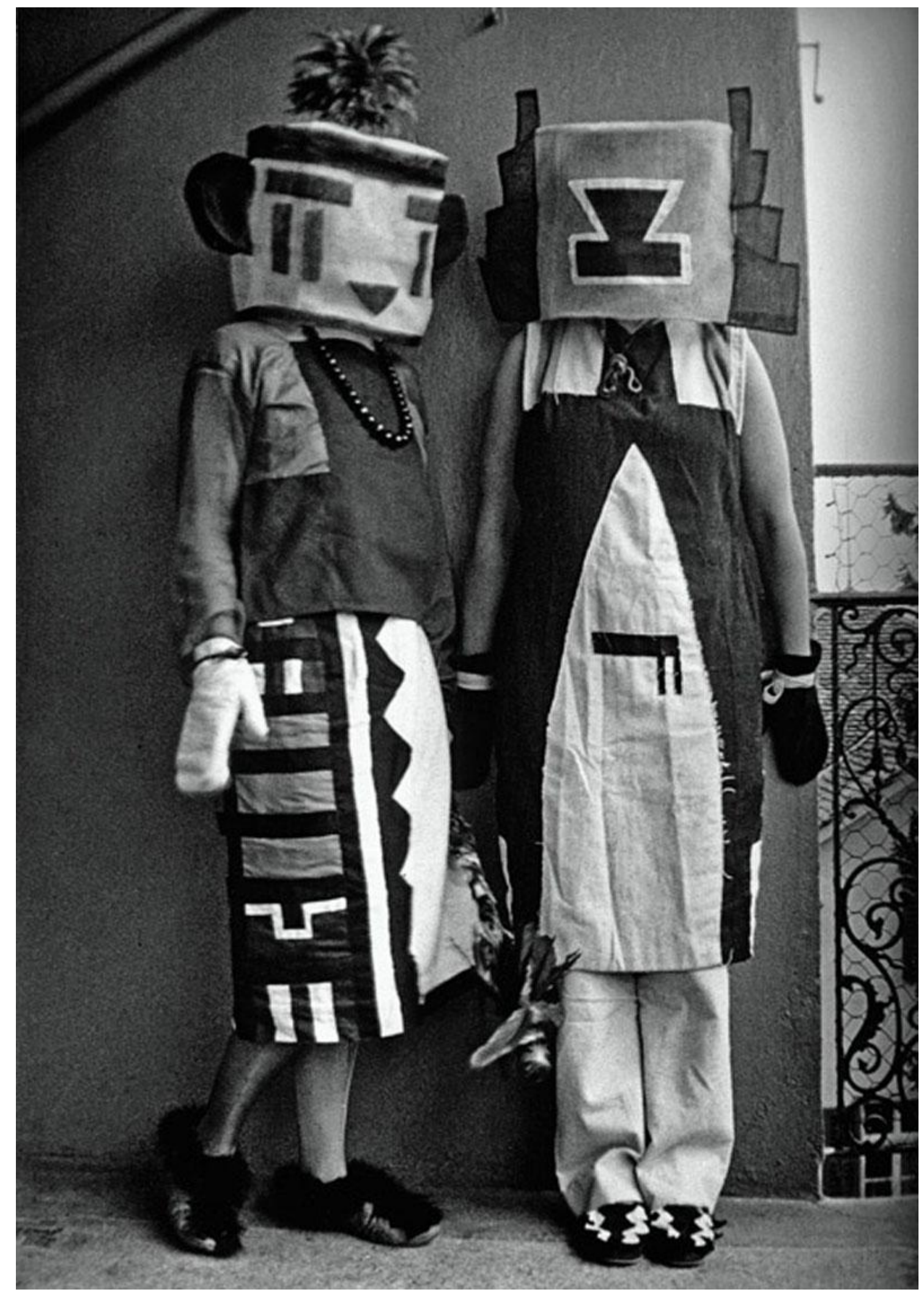

Placa 3. Hans Jan Arp y Sophie Tabeur. Dada Puppets \& Surreal Geometry 


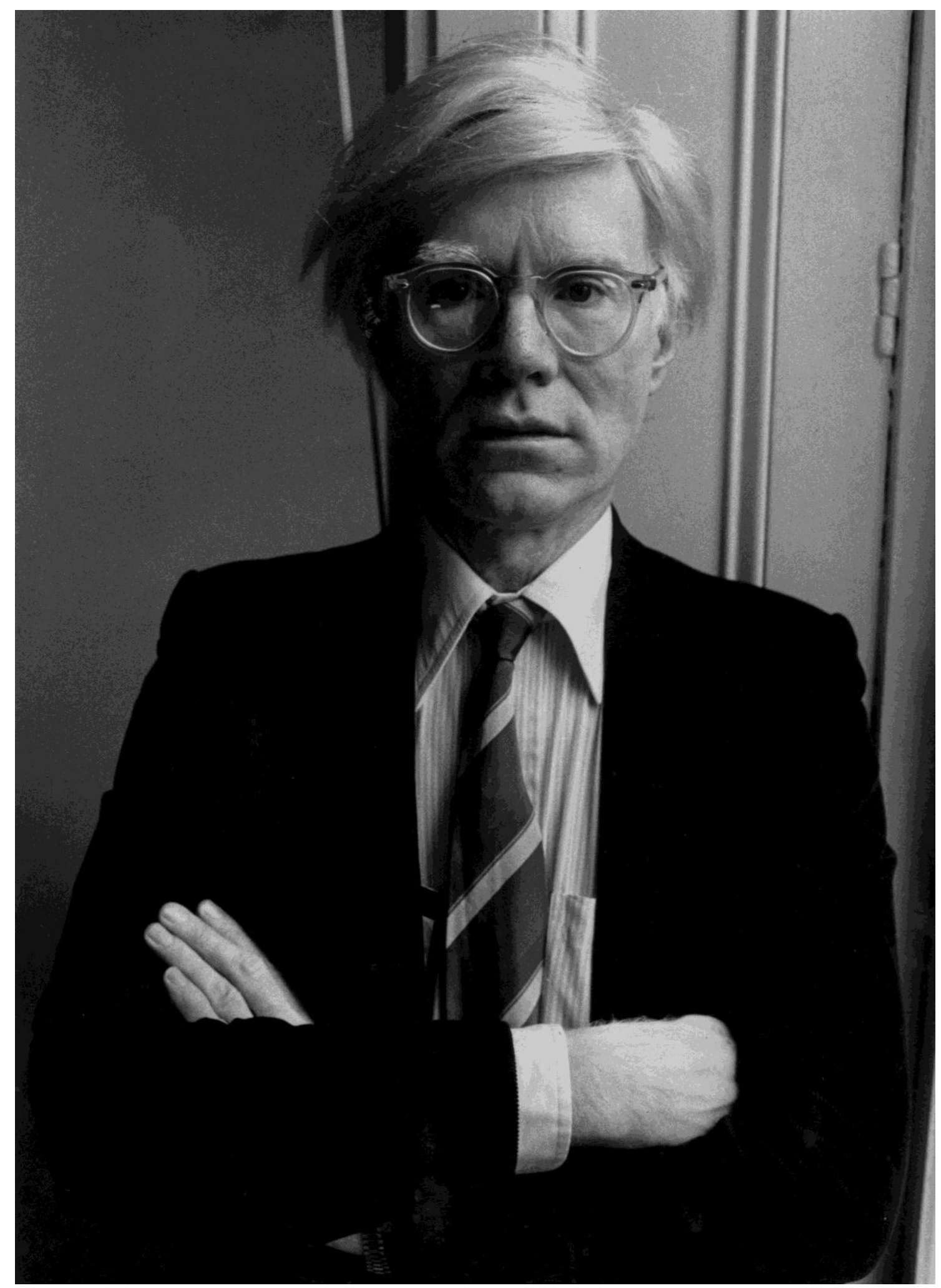

Placa 4. Andy Warhol. Autorretrato. 


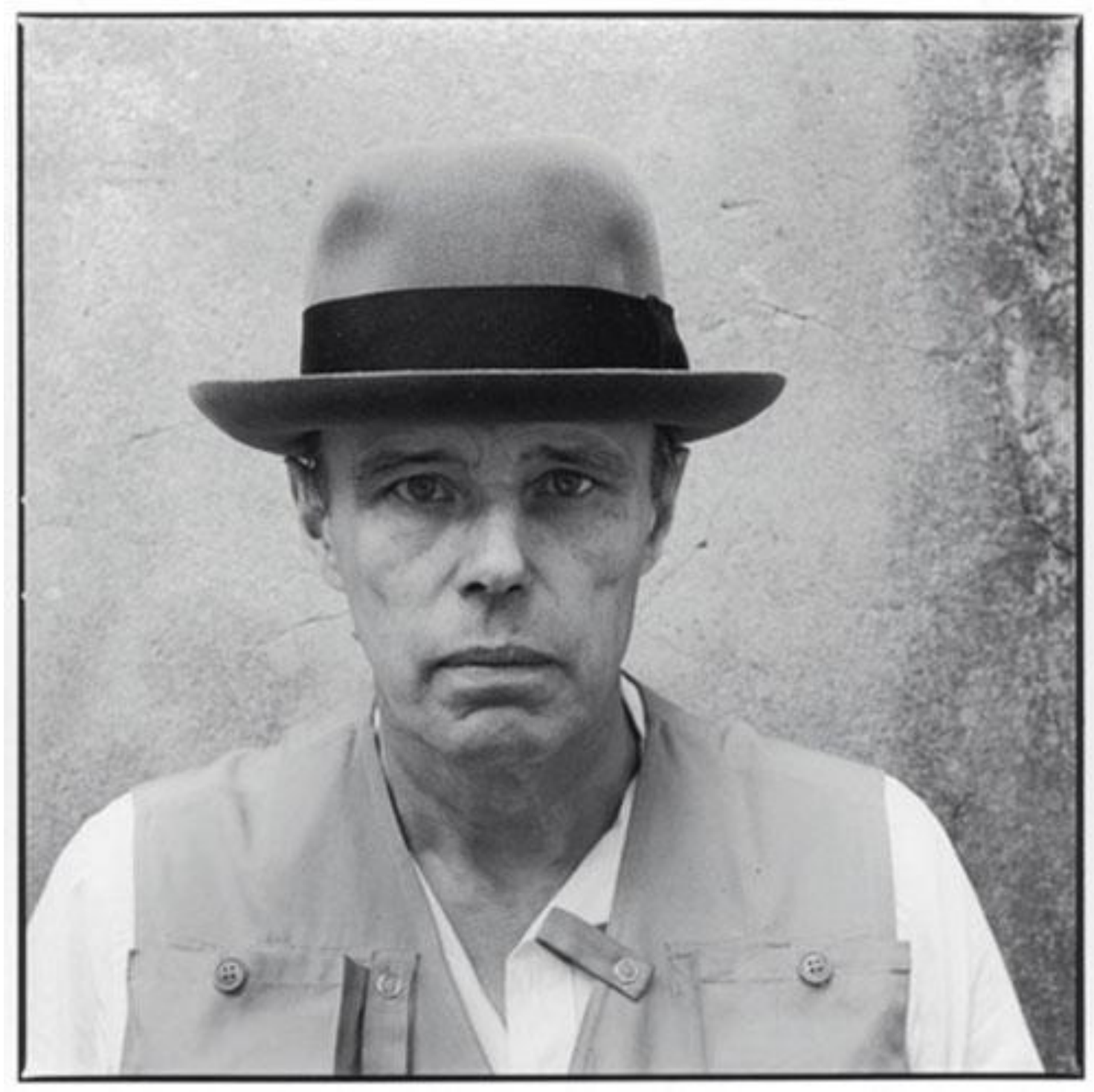

Placa 5. Joseph Beuys. 


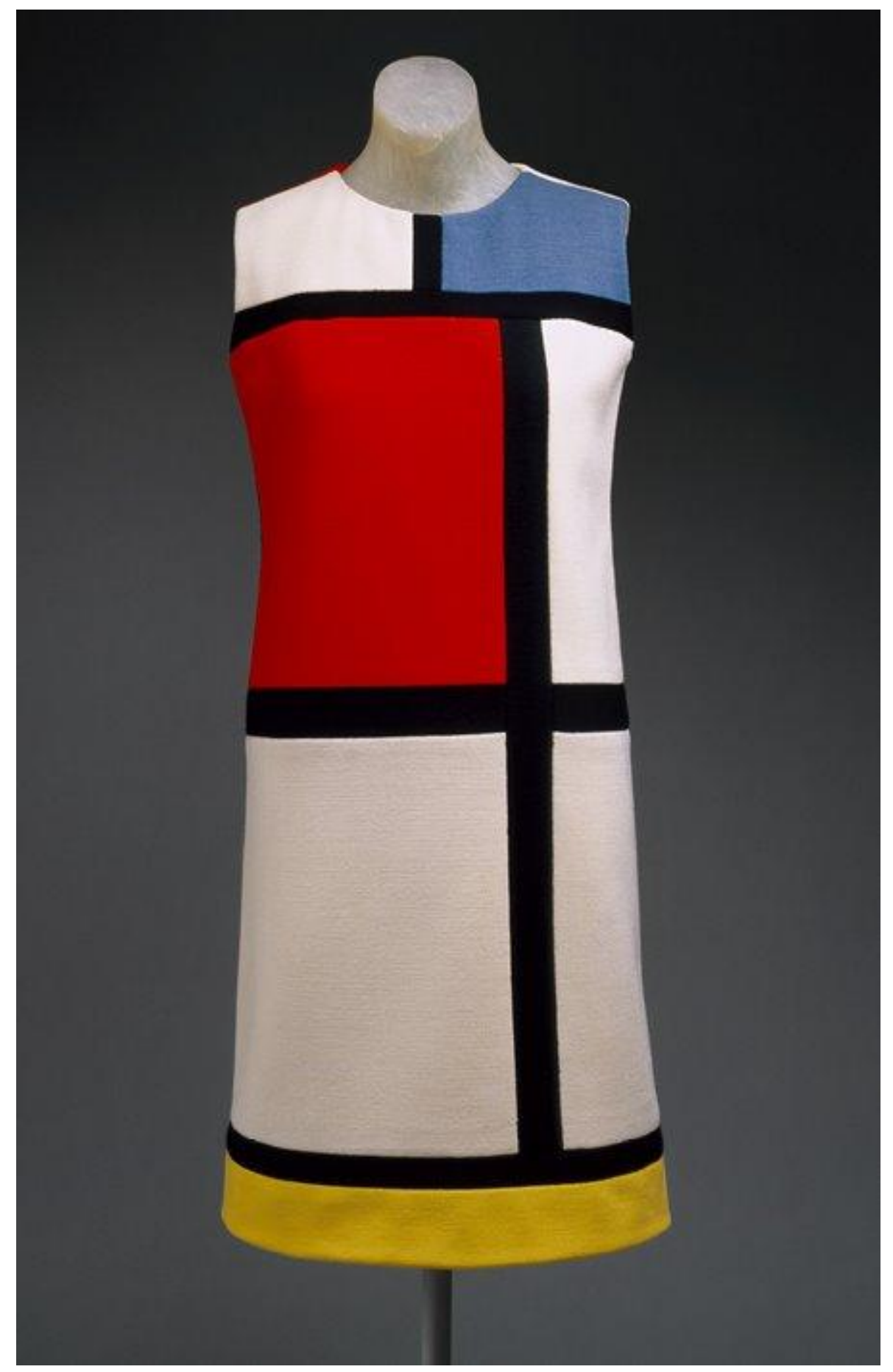

Placa 6. Yves Saint Laurent Mondrian vestido de día. Otoño, 1965. 


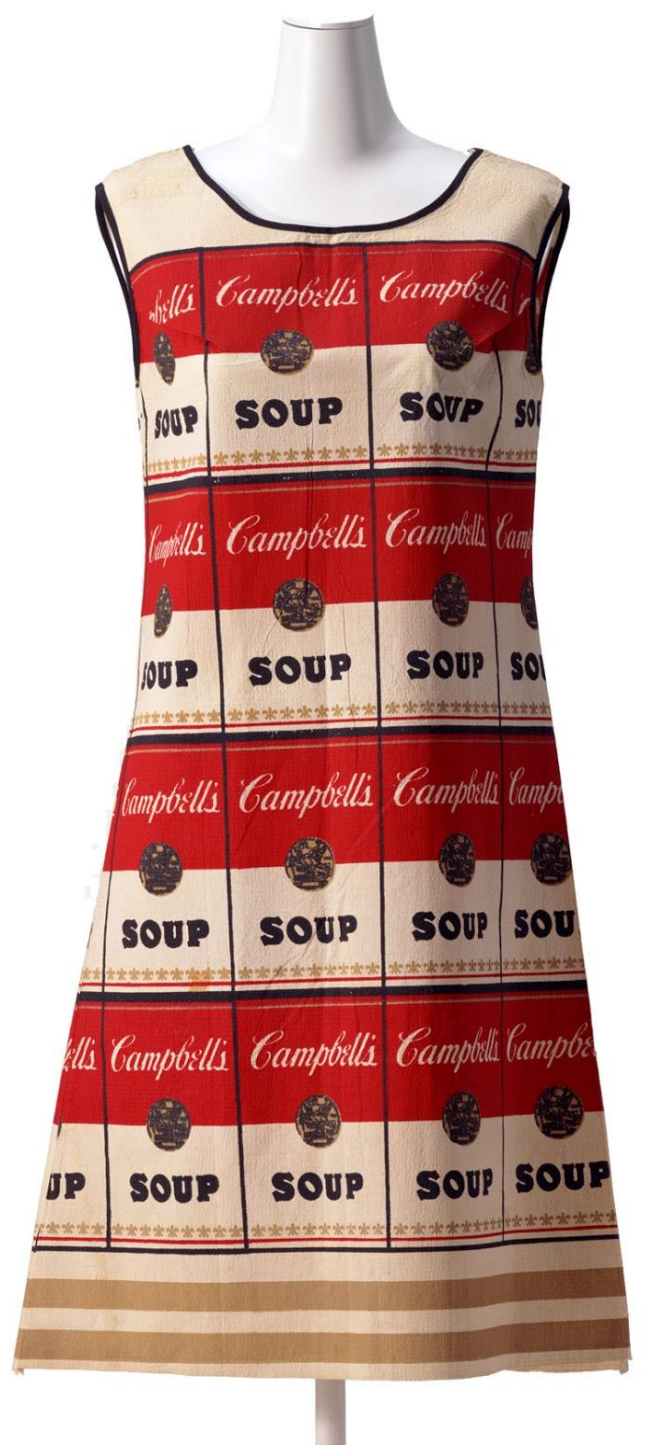

Placa 7. Andy Warhol. The Souper Dress. 1966-1967. 

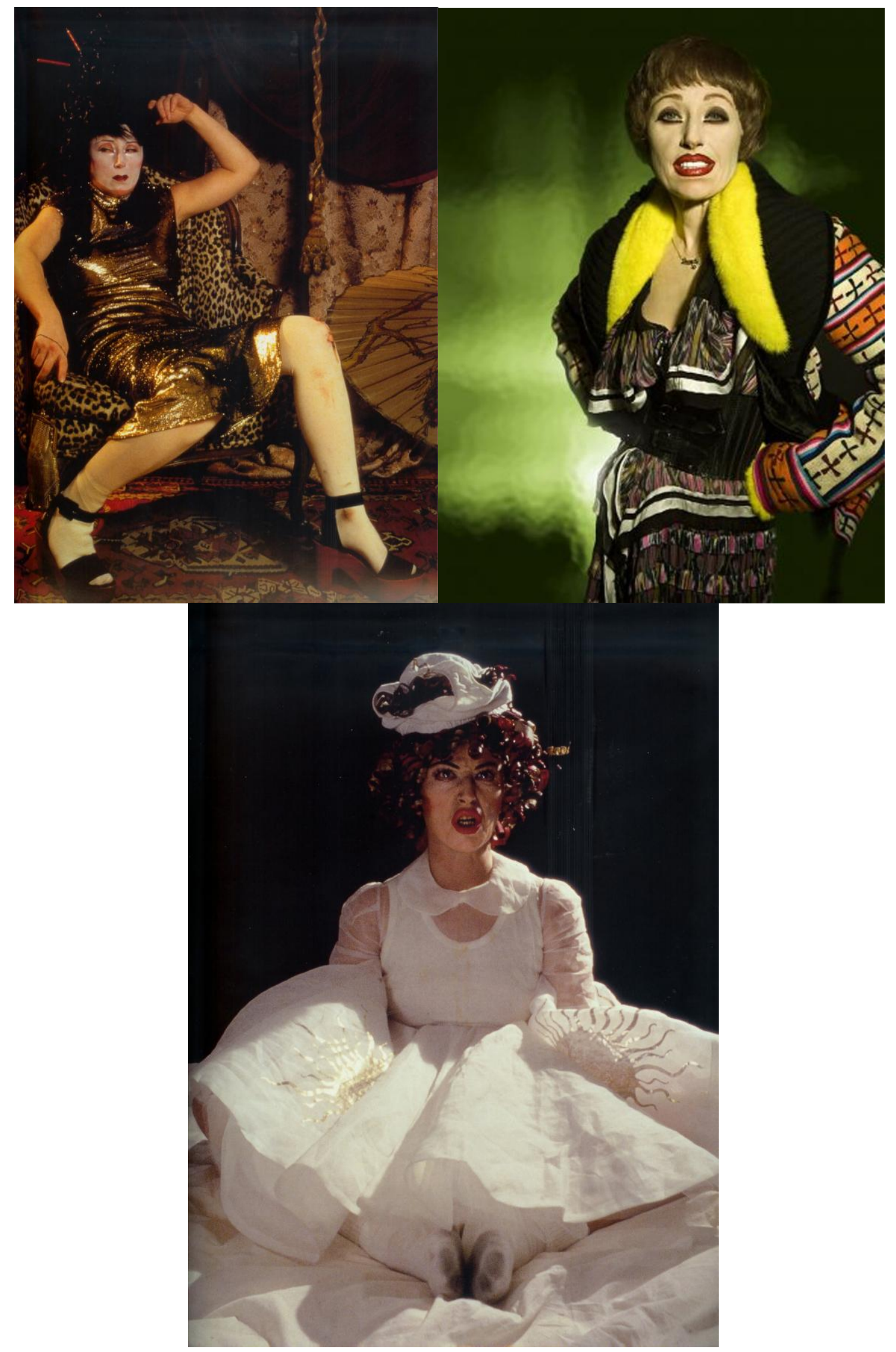

Placas 8. Cindy Sherman. Fashion Series 


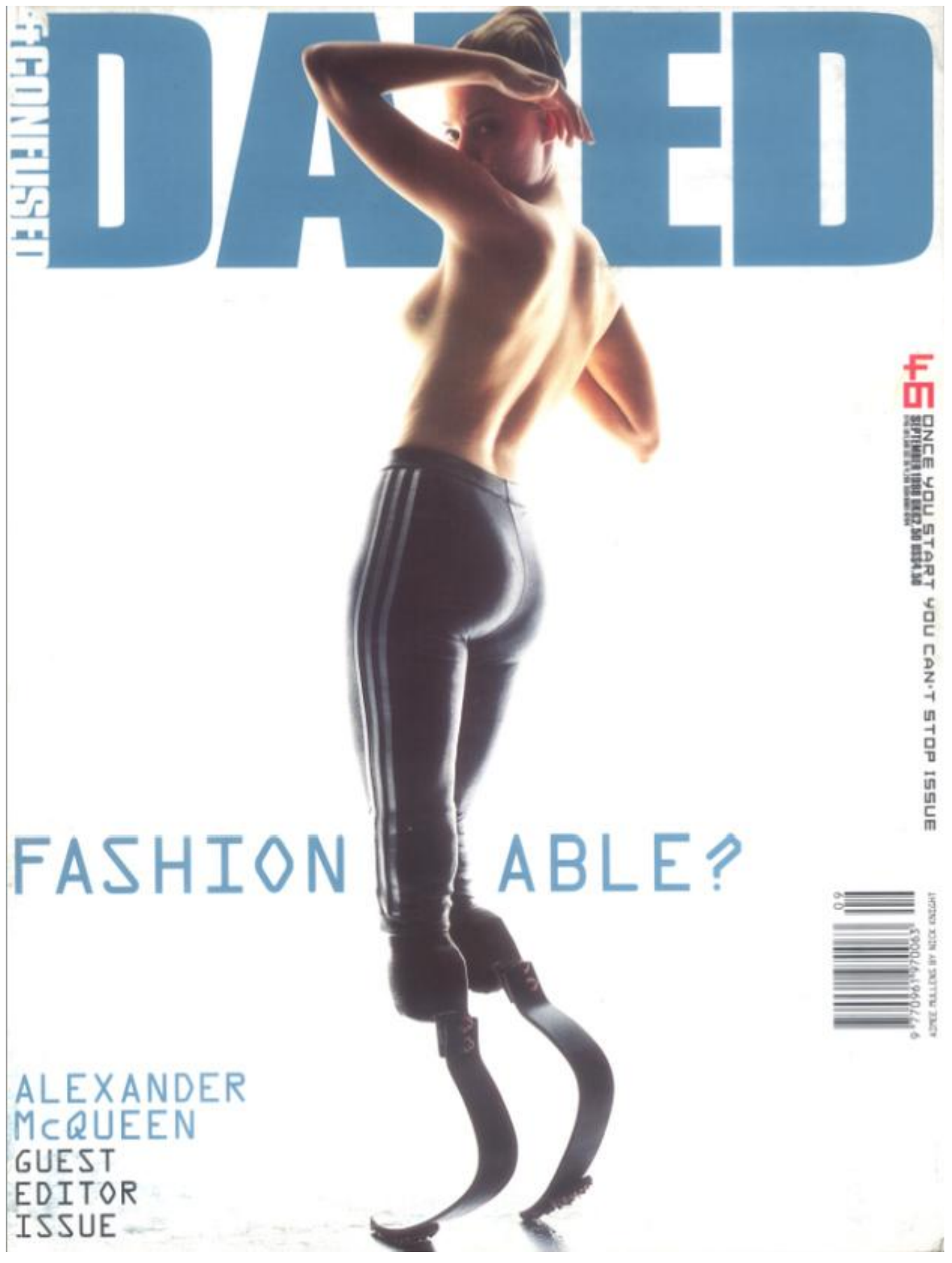

Placa 9. Revista Dazed and Confused. Septiembre, 1998. 


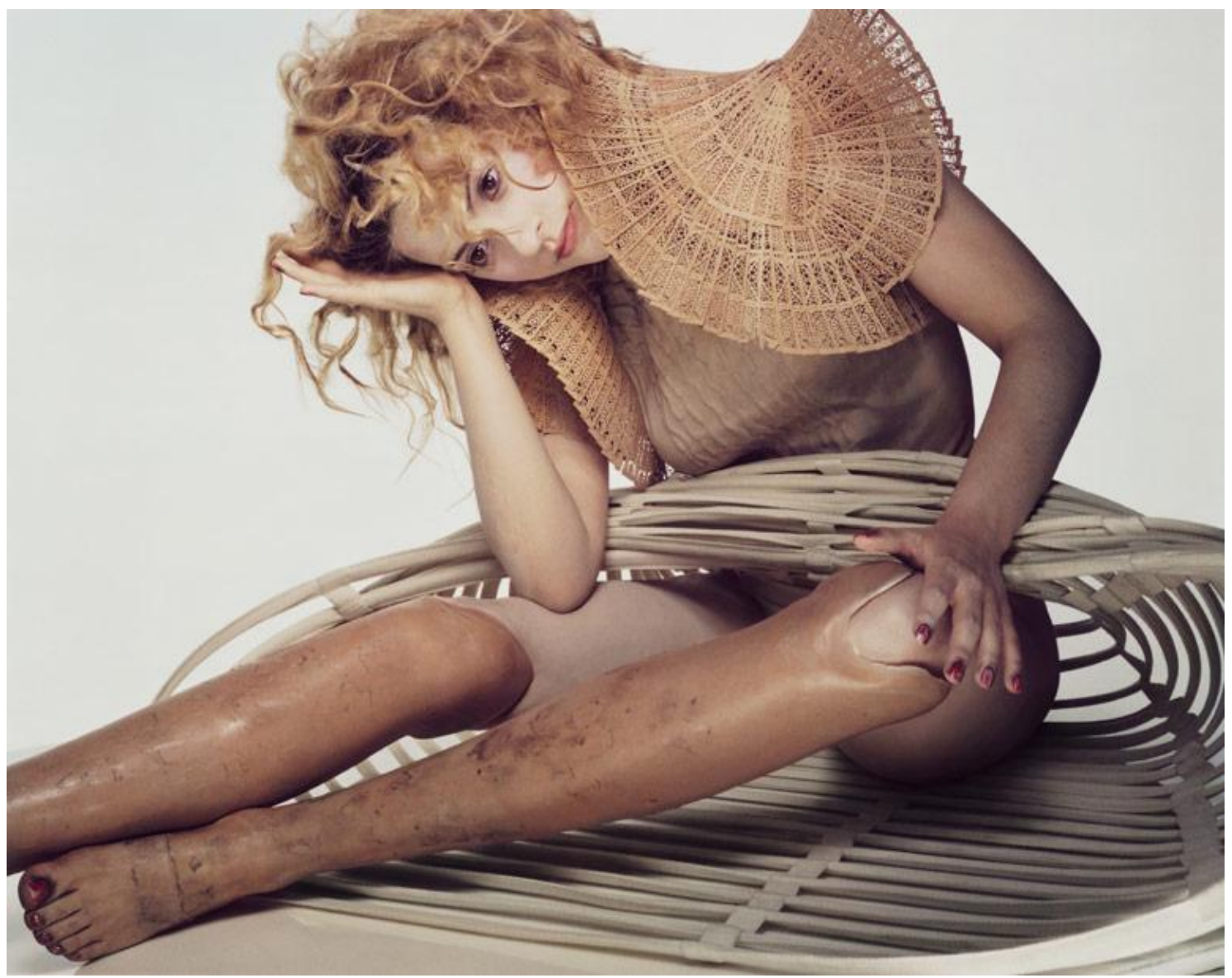

Placa 10. Aimee Mullins. 

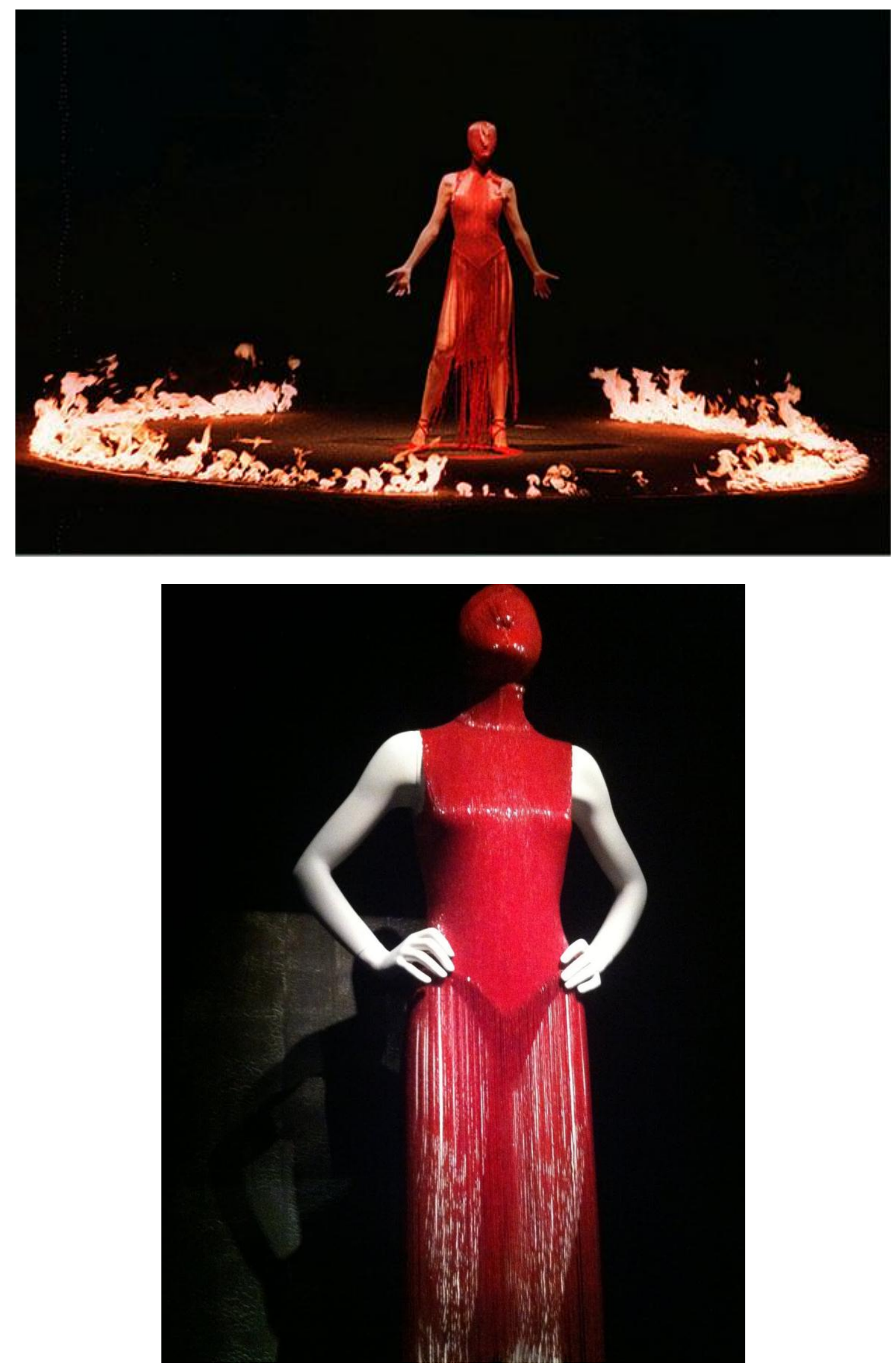

Placa 11. Alexander McQueen. Colección otoño/inverno 1998. 


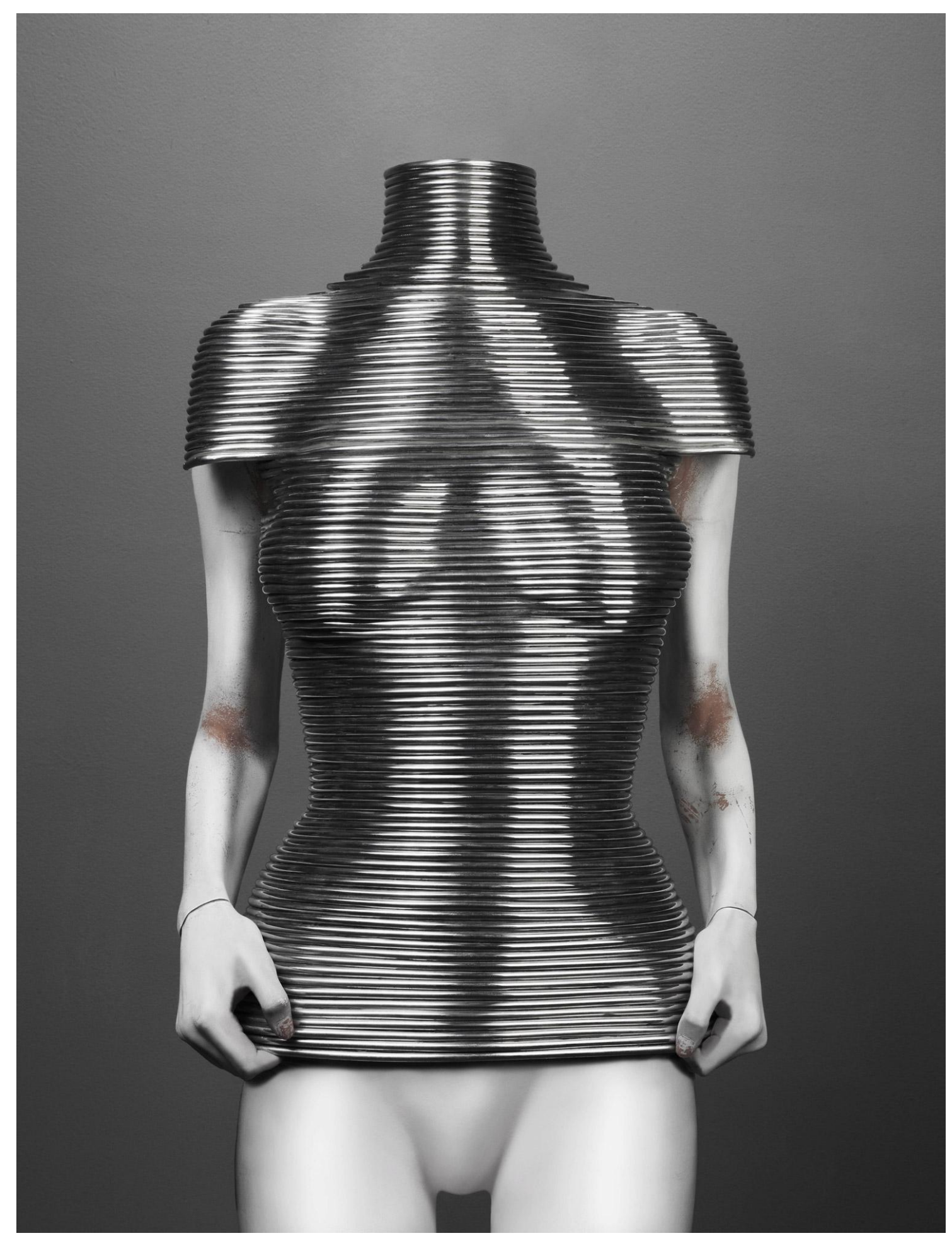

Placa 12. Alexander McQueen. Corset. 


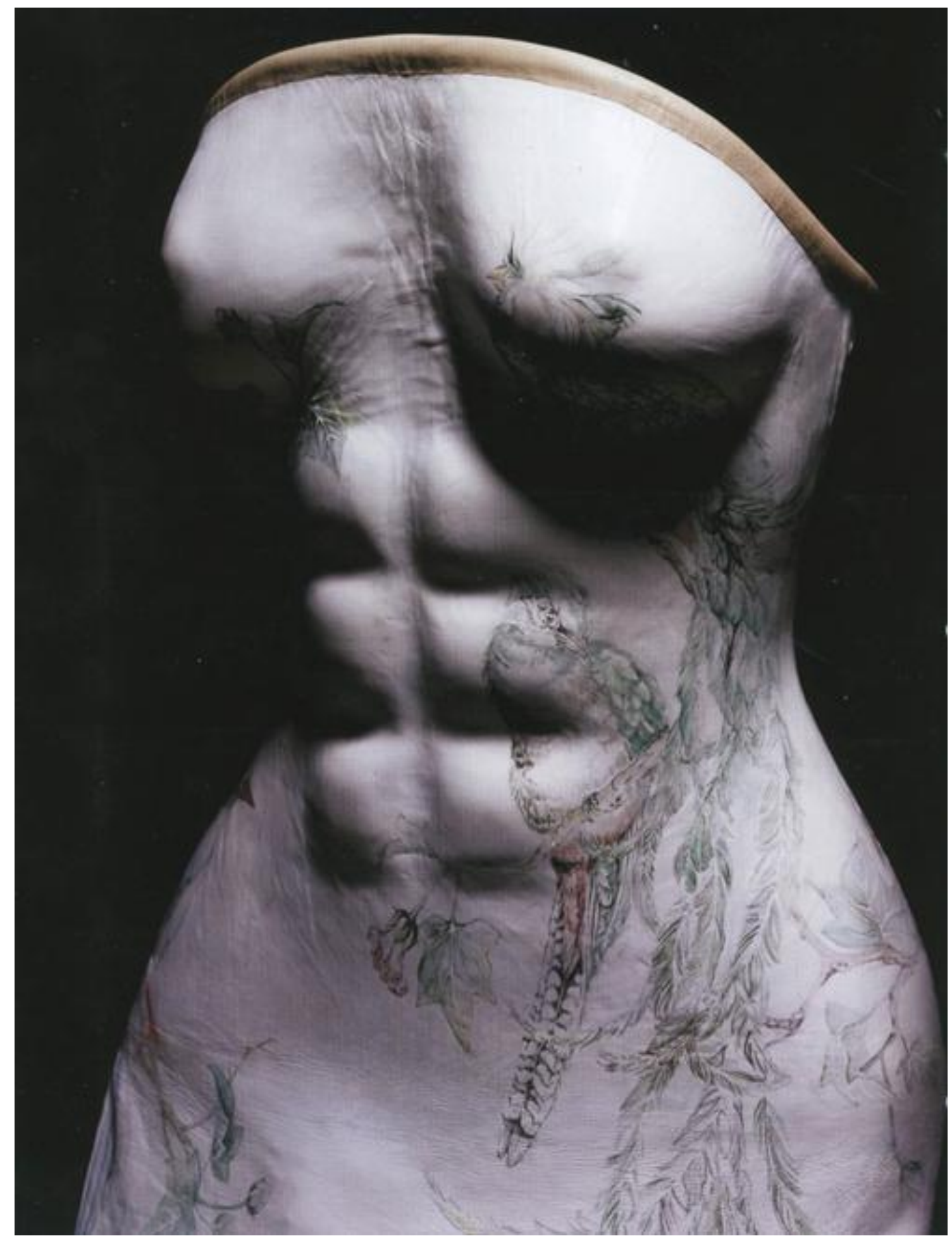

Placa 12a. Alexander McQueen. Corset. 


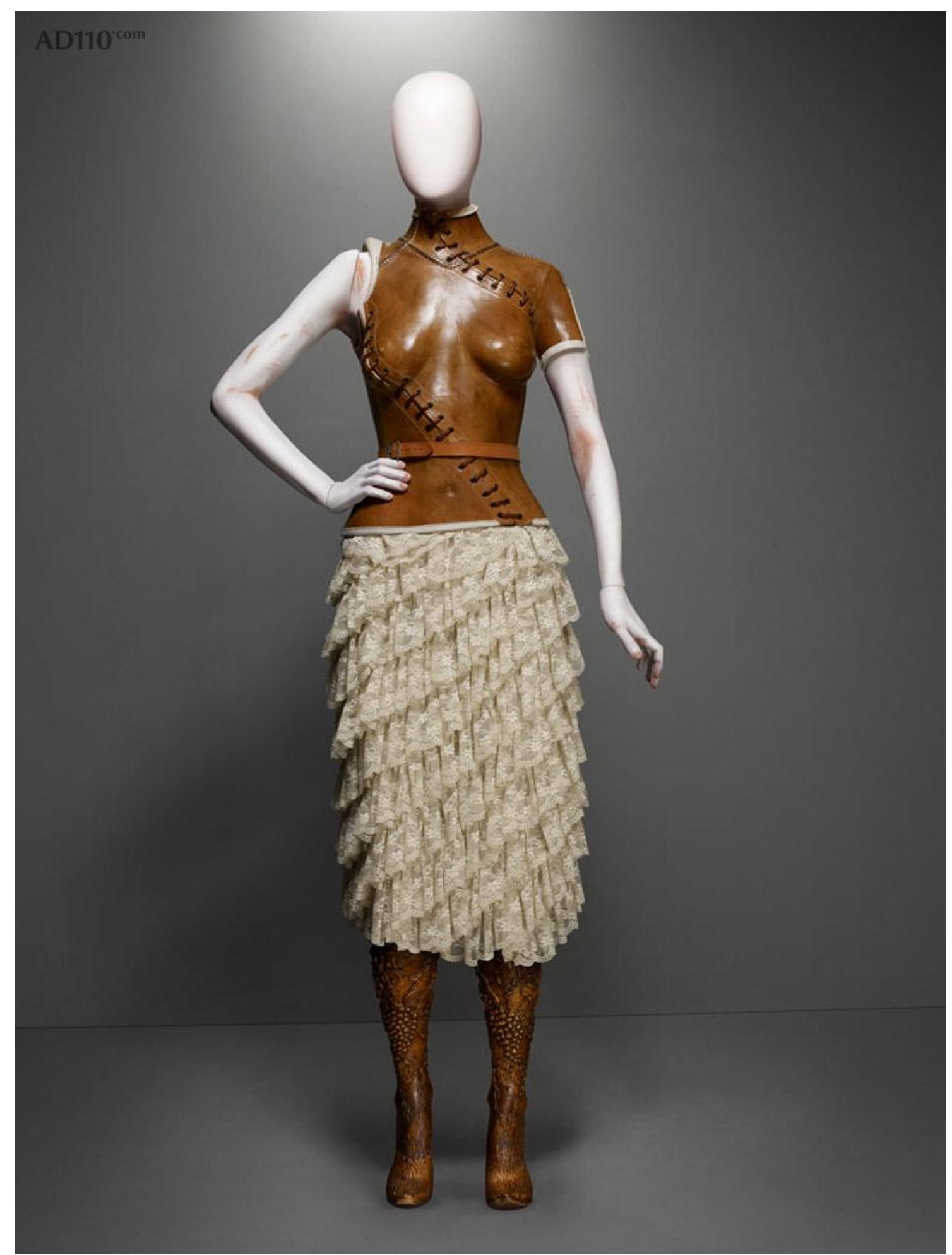

Placa 12b. Alexander McQueen, Corset. 


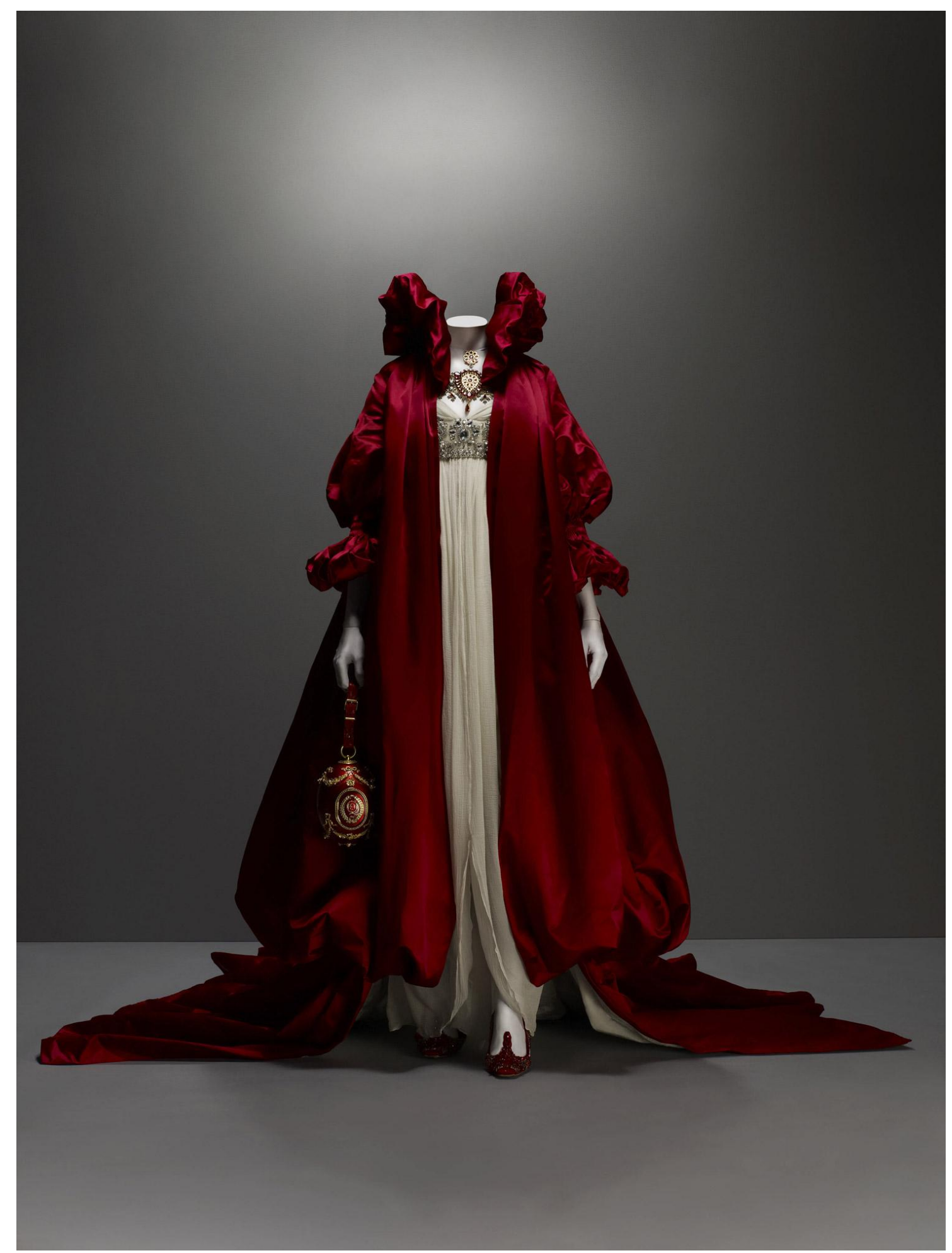

Placa 13. Alexander McQueen. Colección The Girl Who Lived in a Tree. 


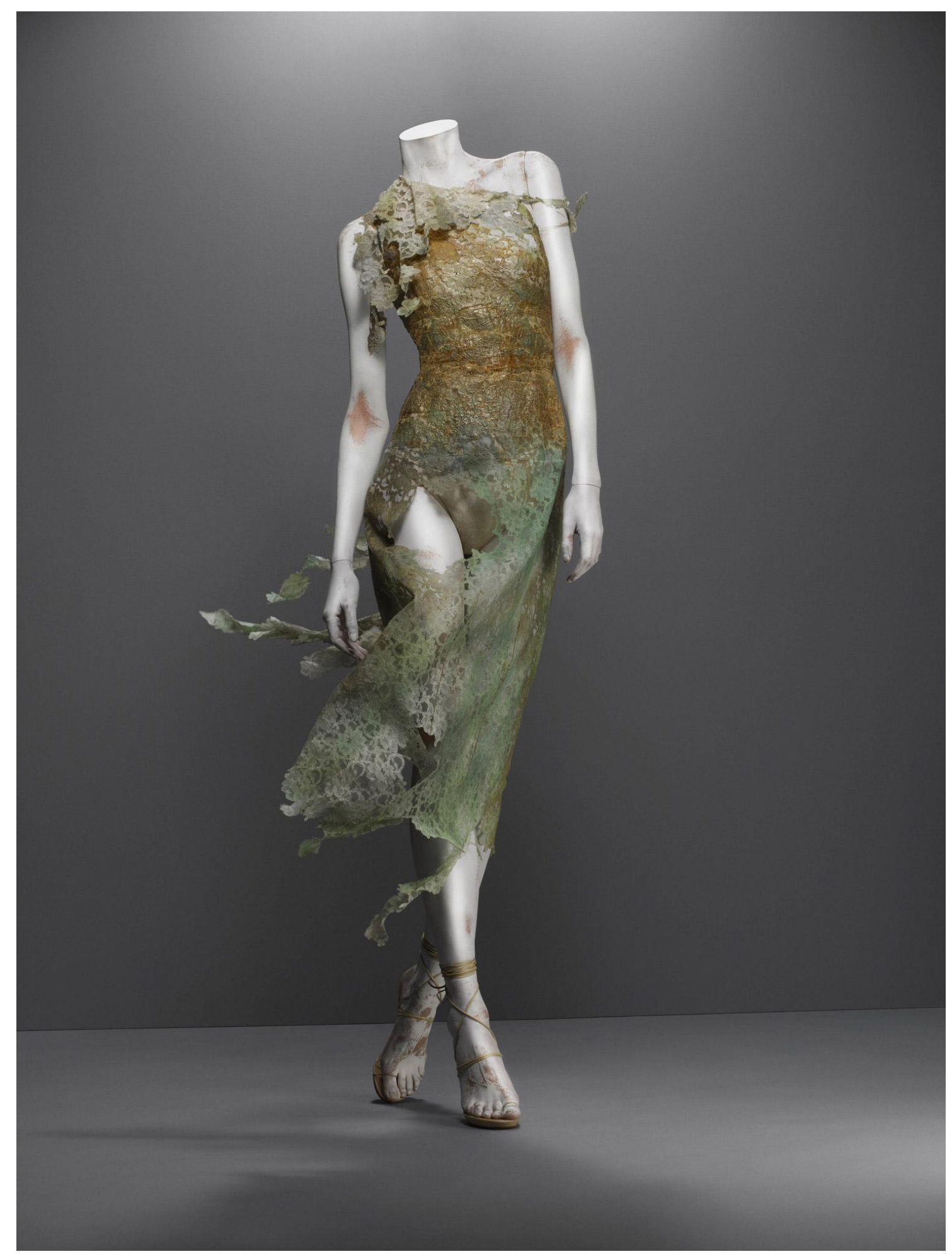

Placa 14. Alexander McQueen. Colección Highland Rape. 


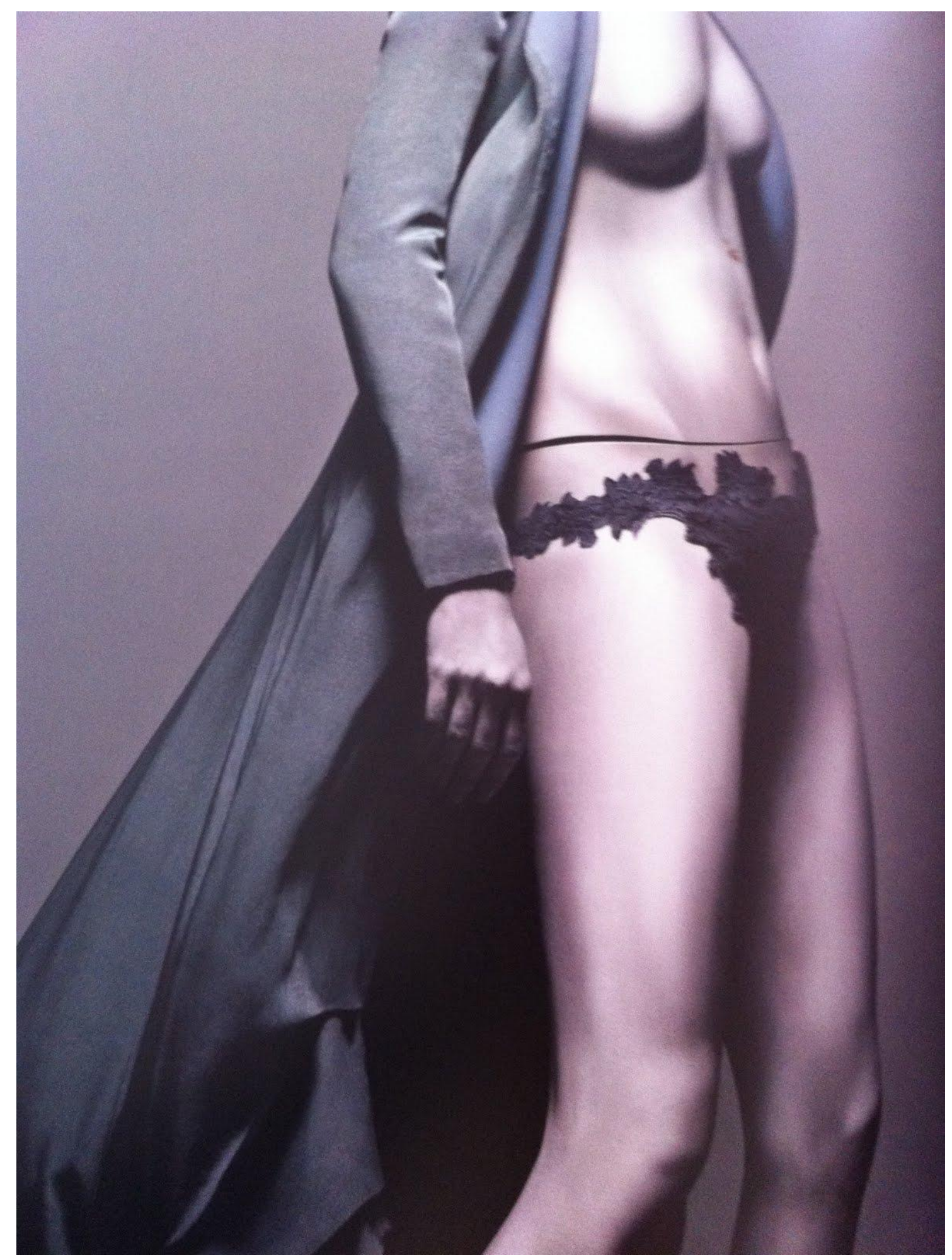

Placa 14a. Alexander McQueen. Colección Highland Rape. 


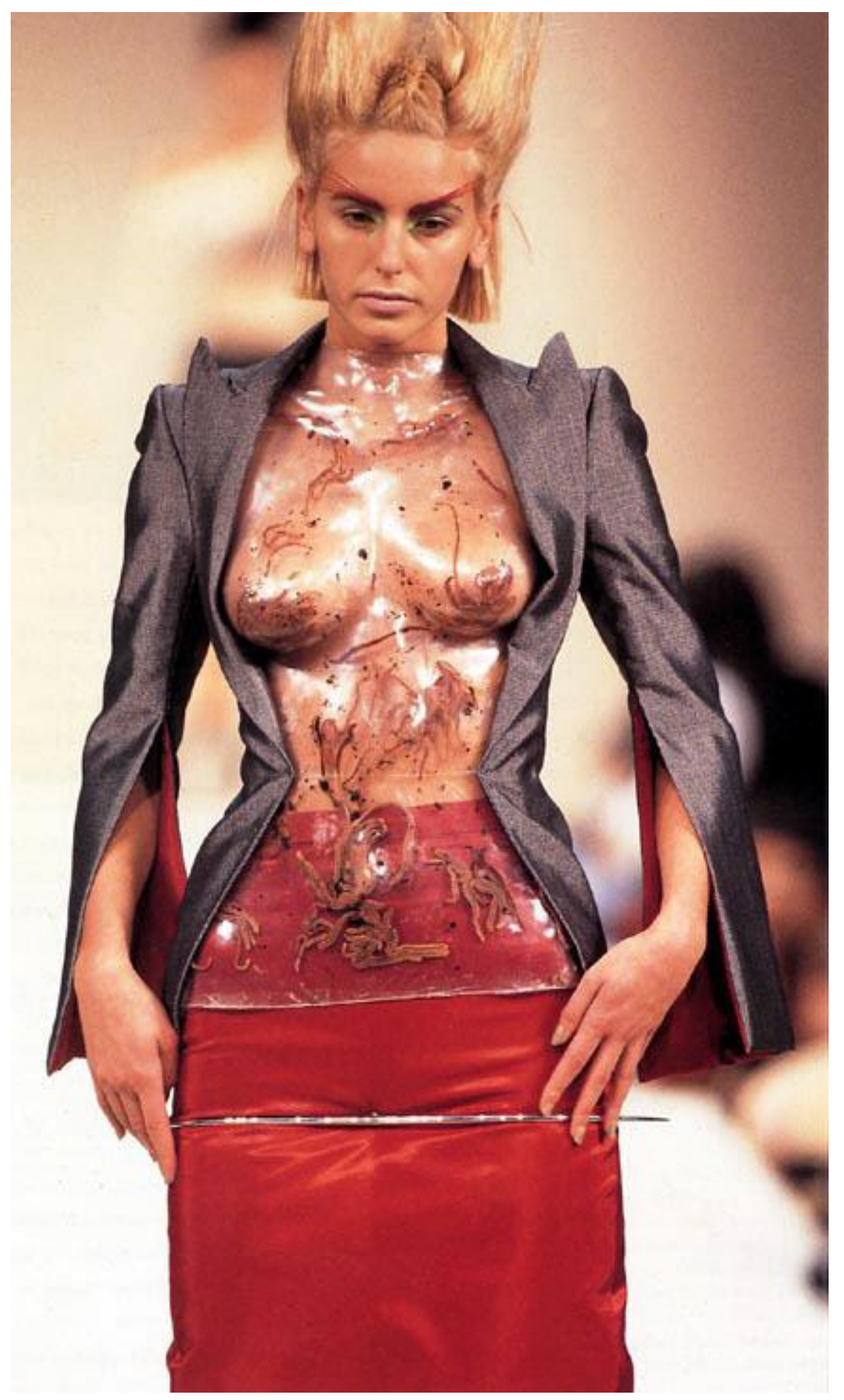

Placa 15. Alexander McQueen. Colección The Hunger. 


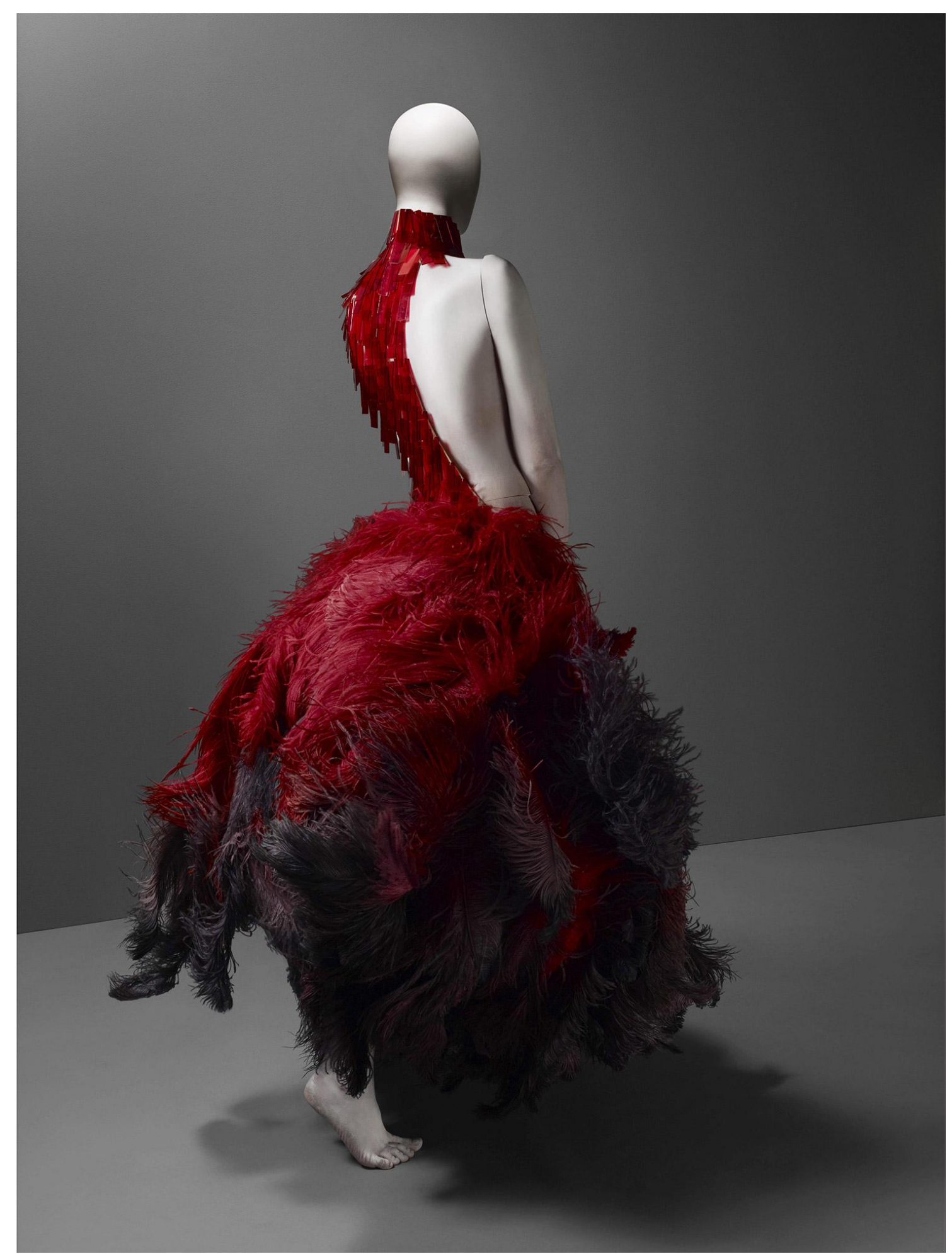

Placa 16. Alexander McQueen. Colección VOSS. 

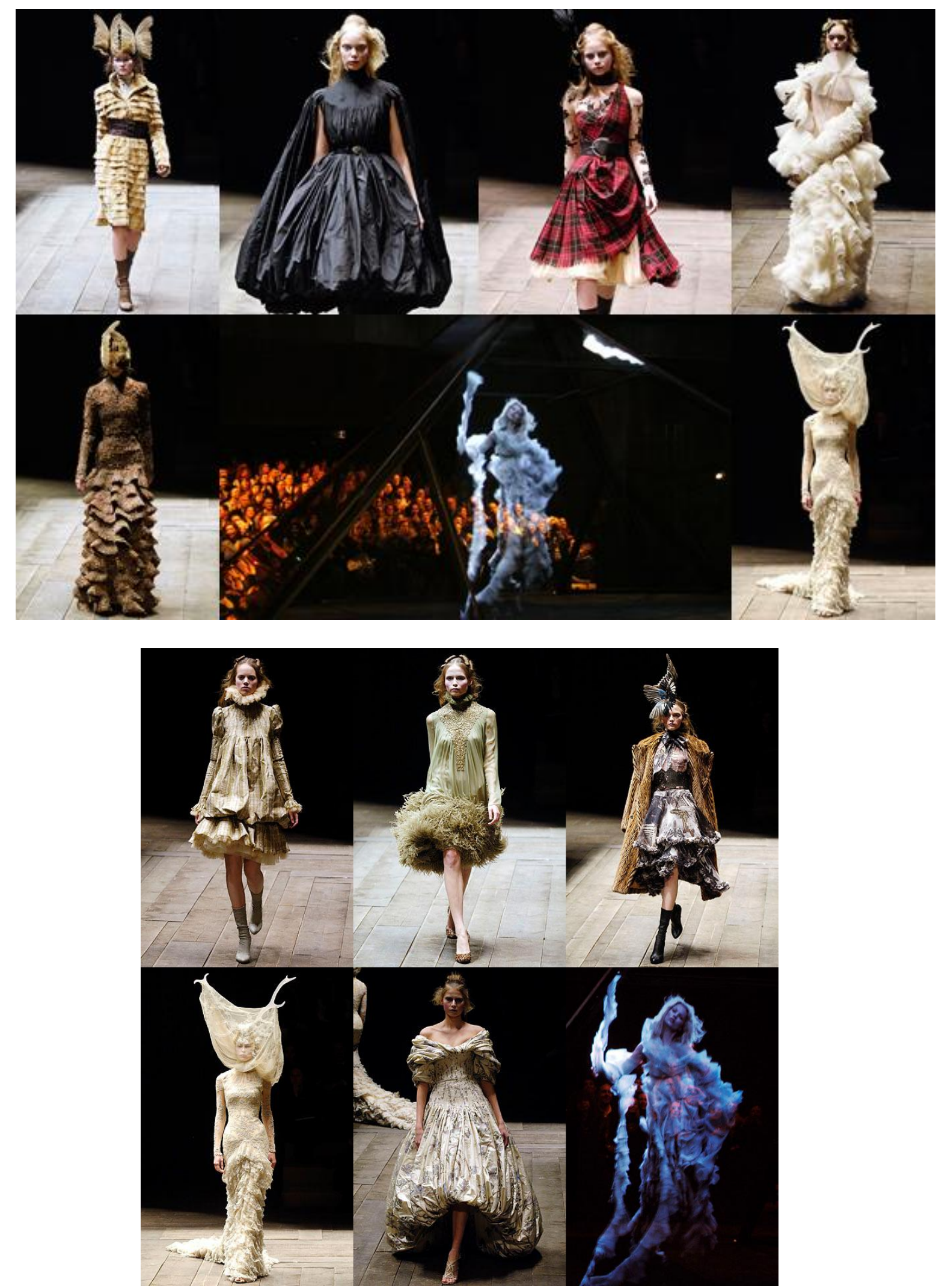

Placa 17. Alexander McQueen. Colección Widows of Culloden. 


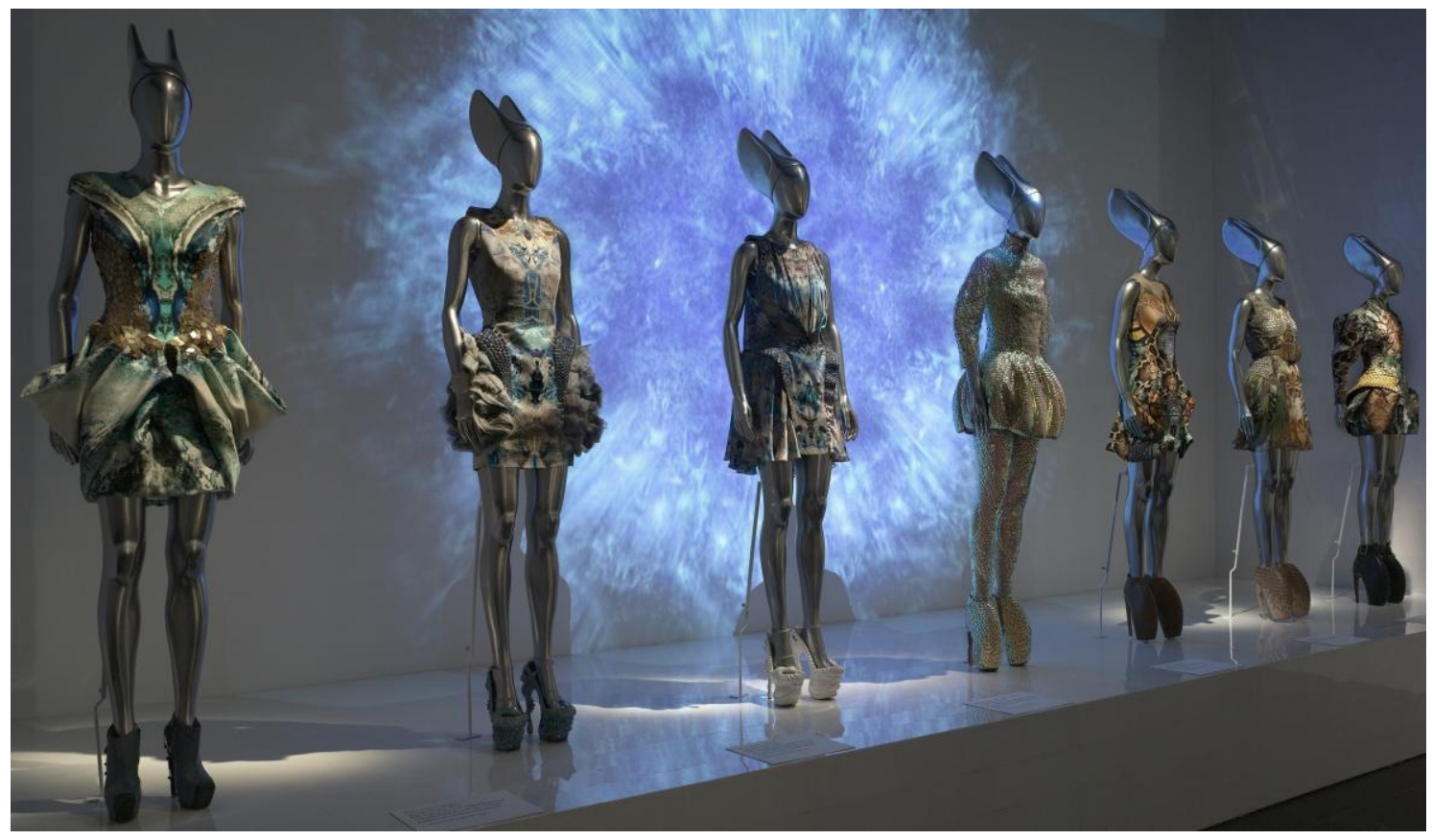

Placa 18. Alexander McQueen. Colección Plato's Atlantis. 


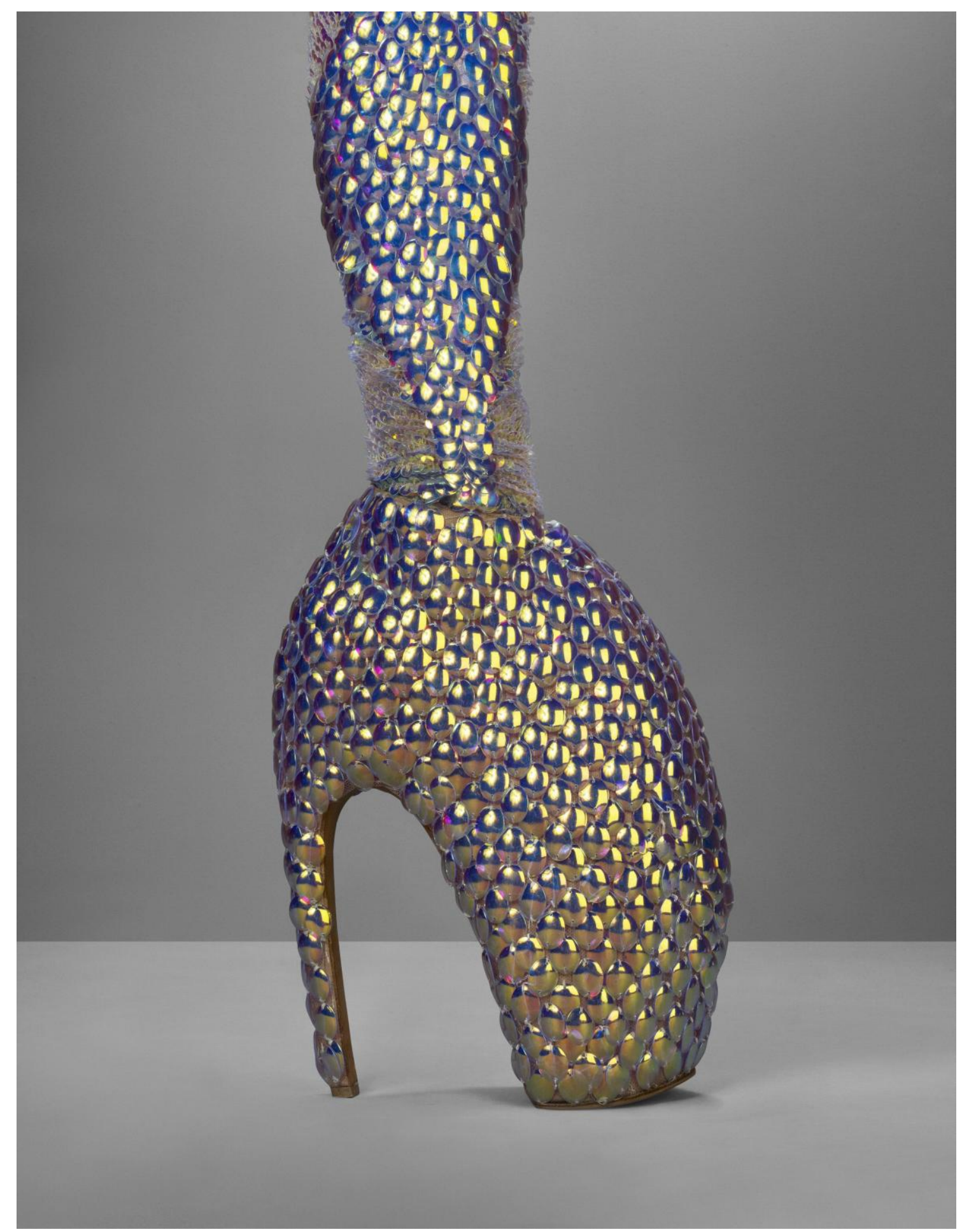

Placa 18a. Alexander McQueen. Colección Plato's Atlantis. 


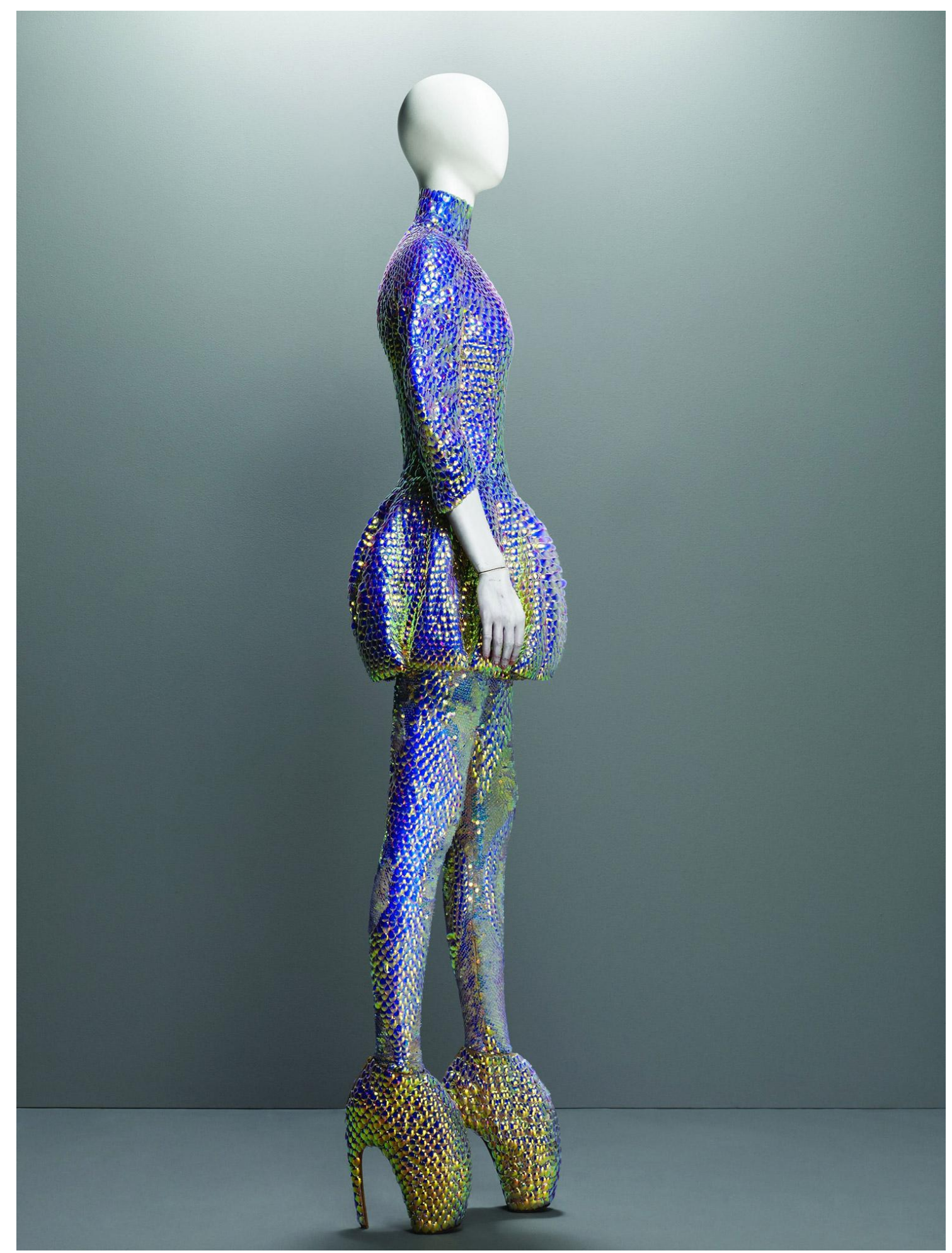

Placa 18b. Alexander McQueen. Colección Plato's Atlantis. 


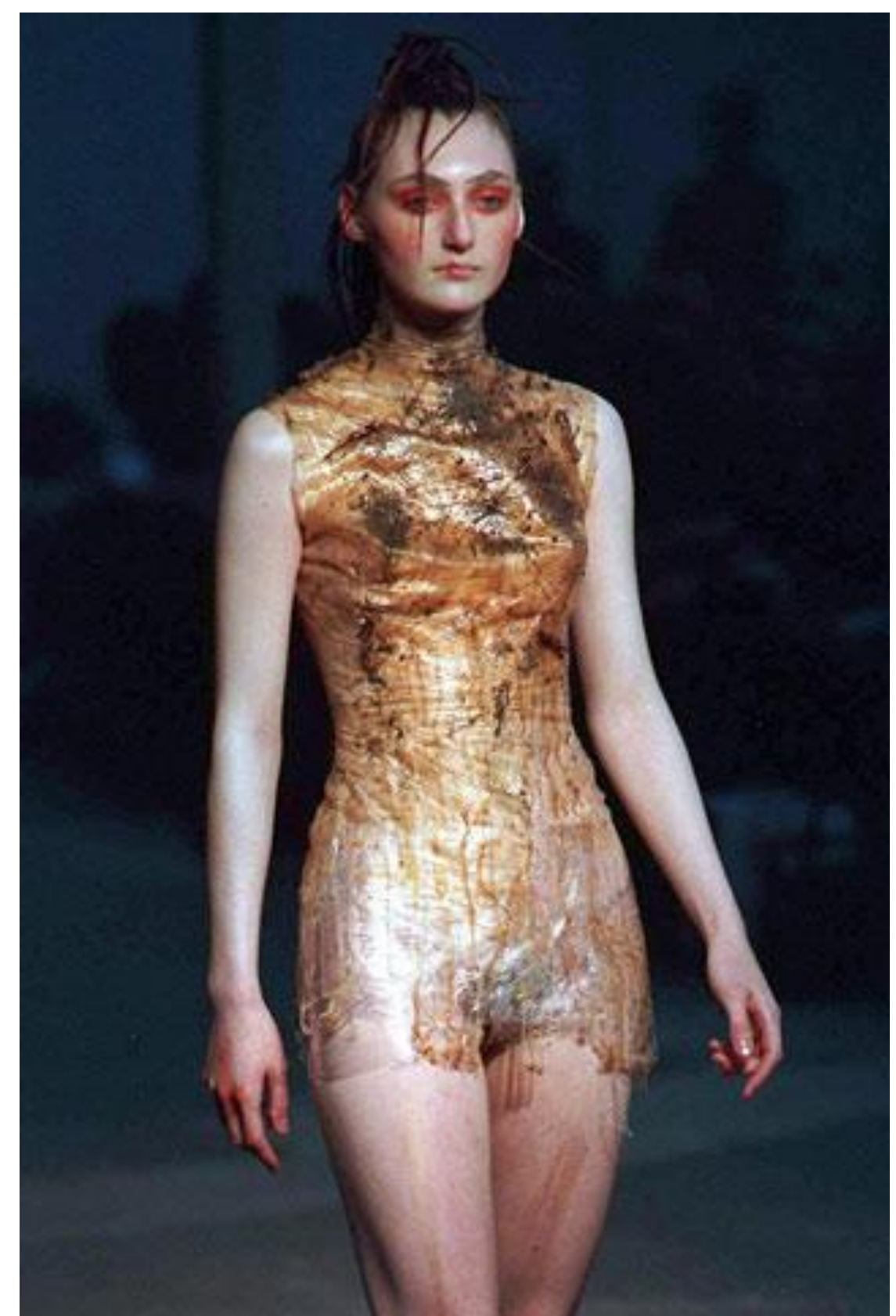

Placa 19. Alexander McQueen. Colección Nihilism. 


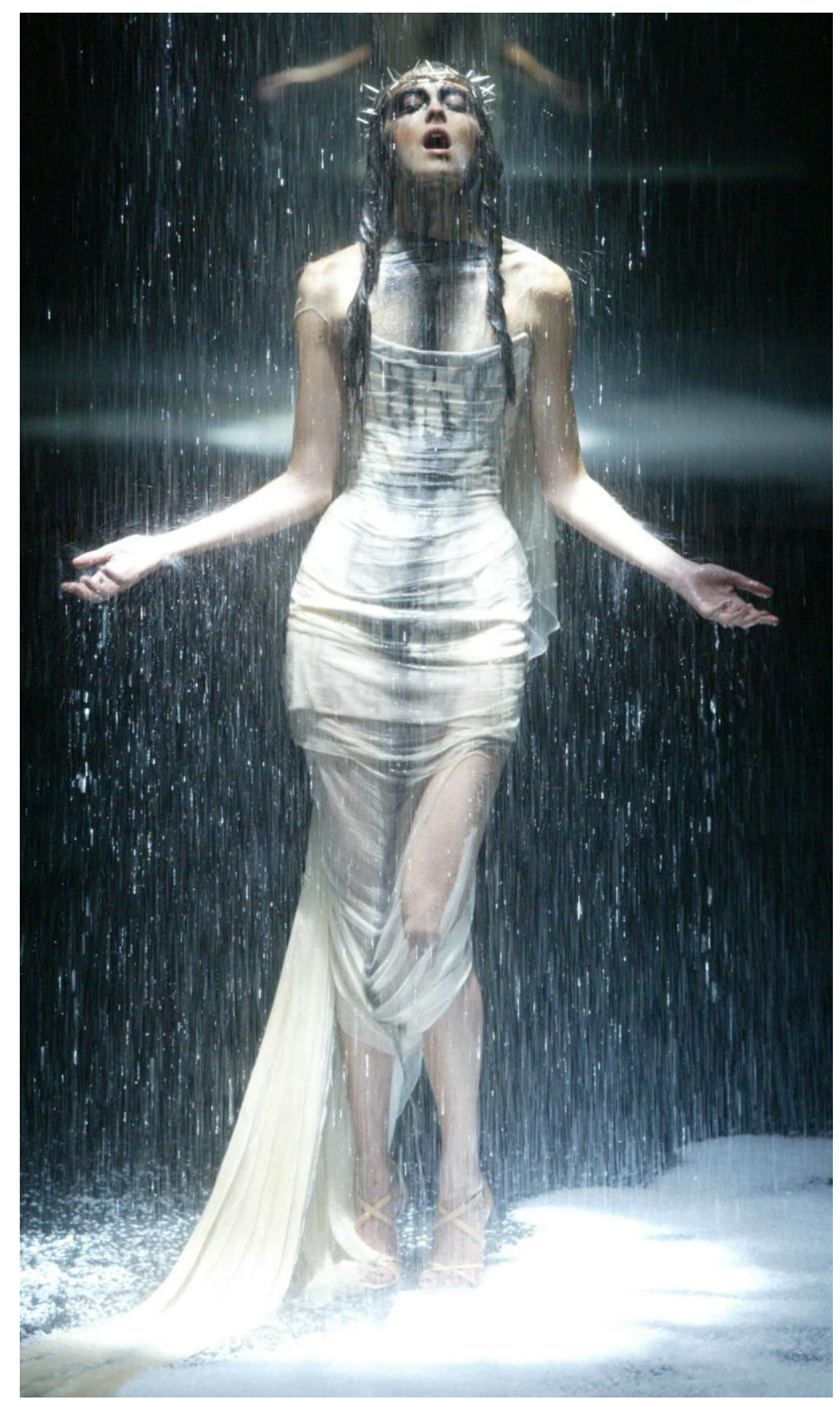

Placa 20. Alexander McQueen. Colección Golden Shower. 


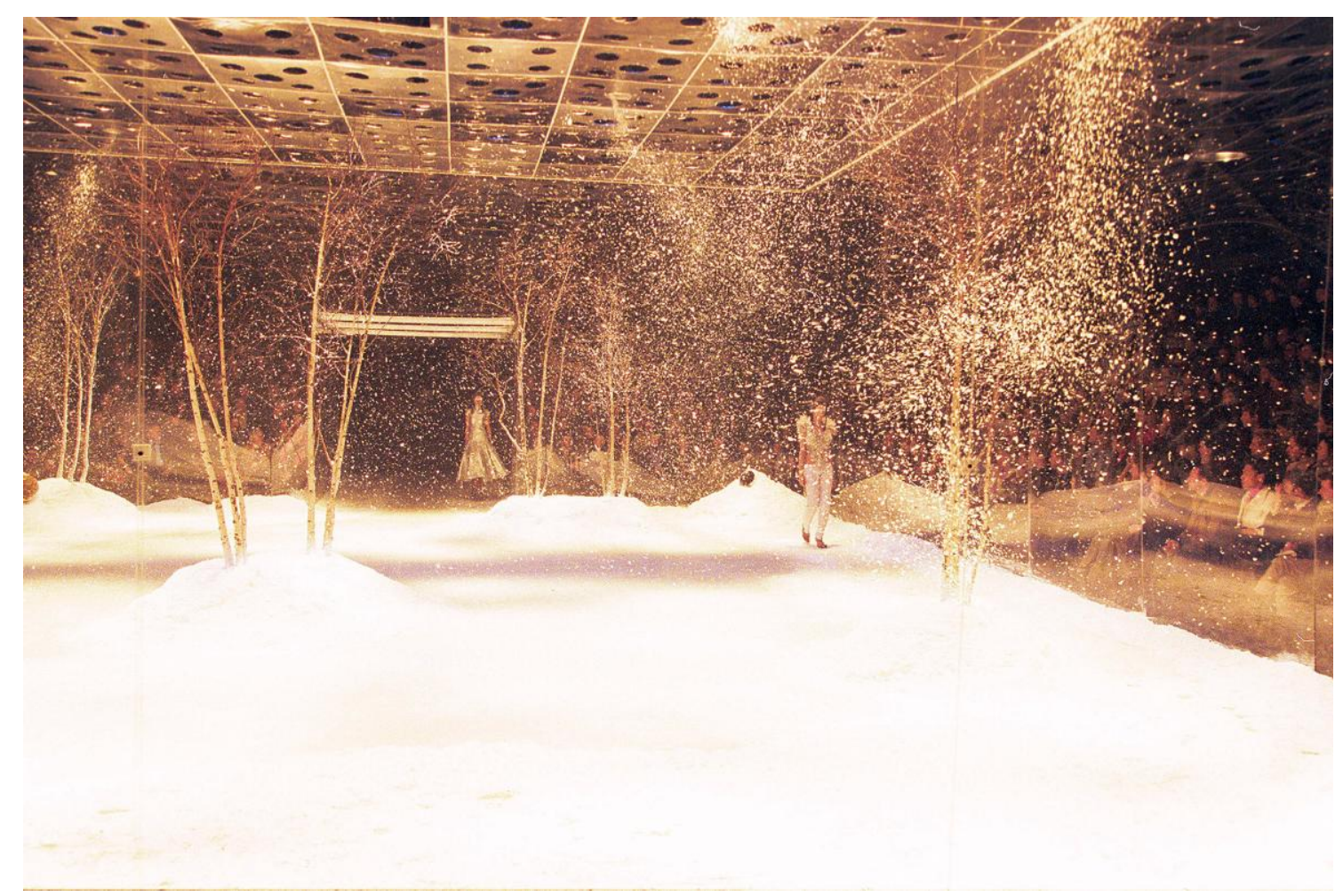

Placa 21. Alexander McQueen. Colección The Overlook. 


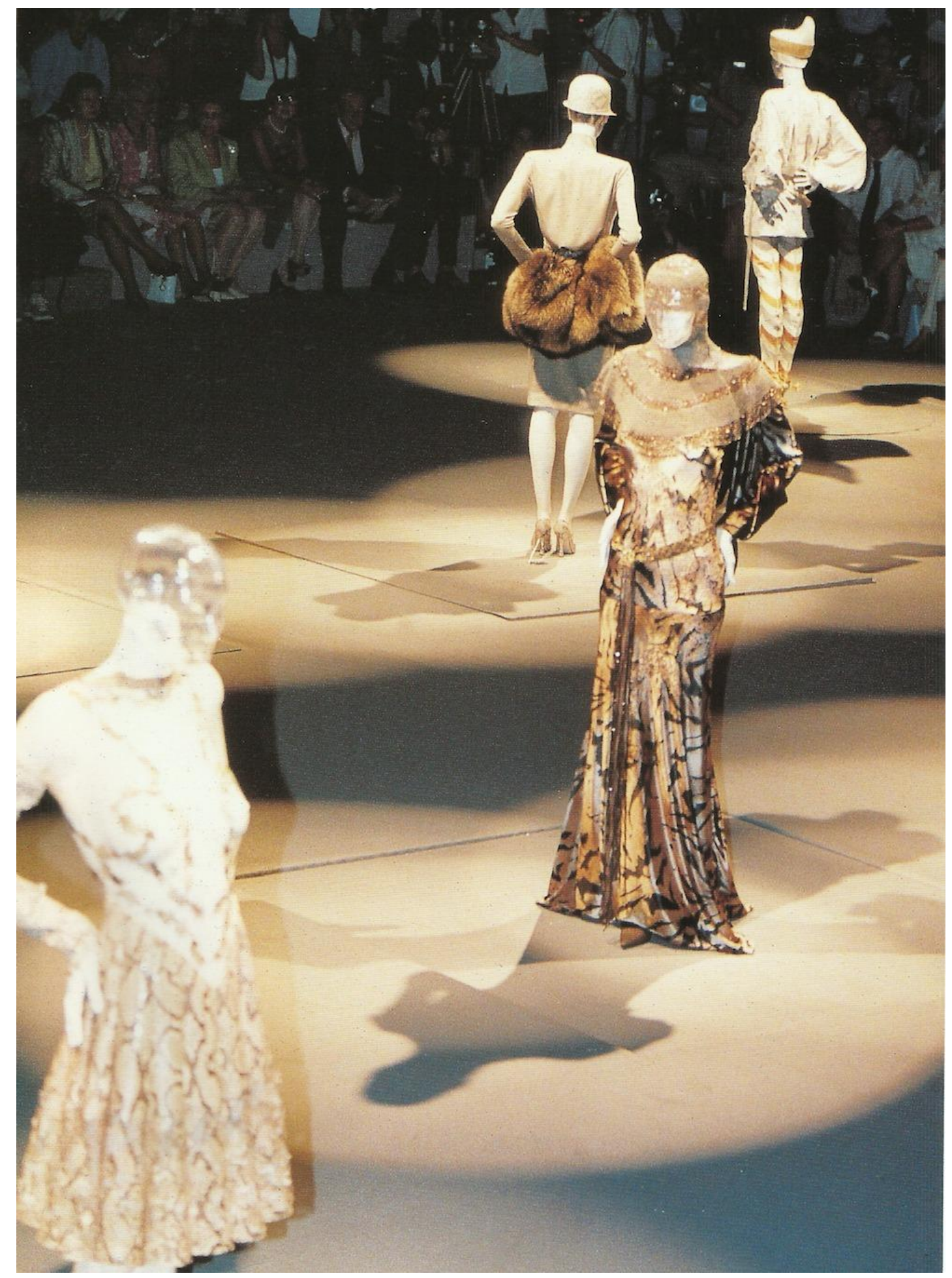

Placa 22. Alexander McQueen. Colección otoño/invierno 1999-2000. 


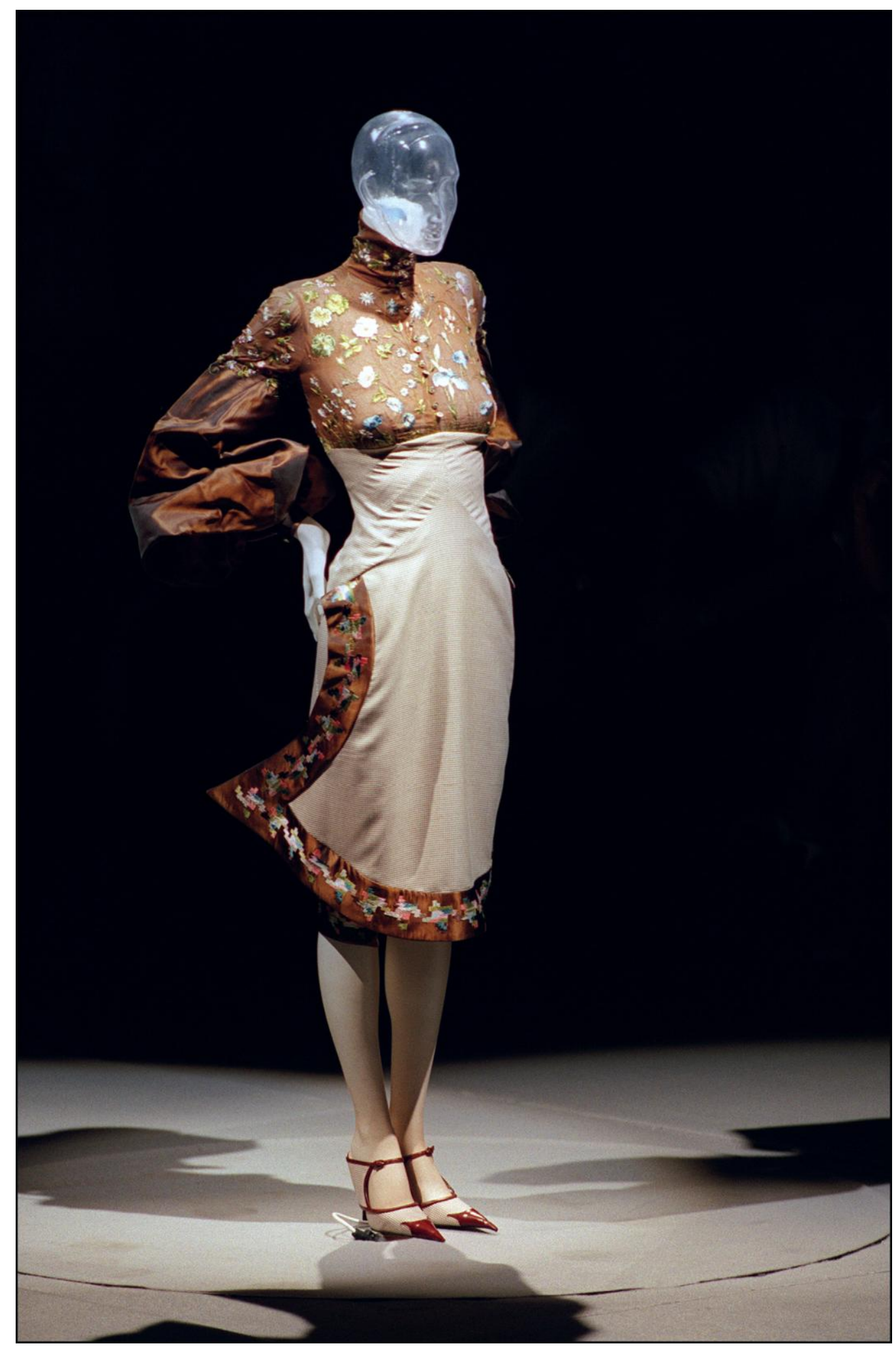

Placa 22a. Alexander McQueen. Colección otoño/invierno 1999-2000. 


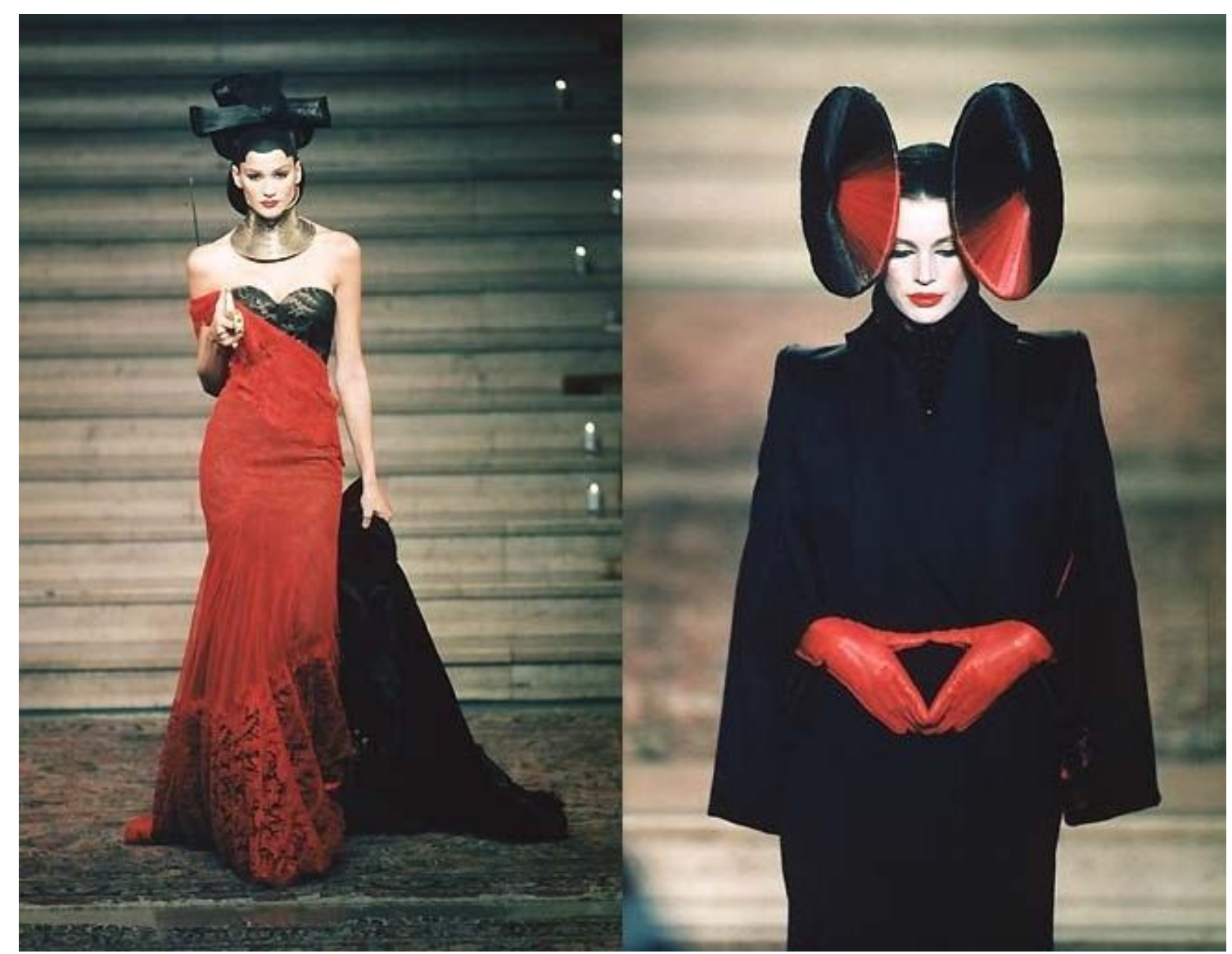

Placa 23. Alexander McQueen. Colección Eclect Dissect. 


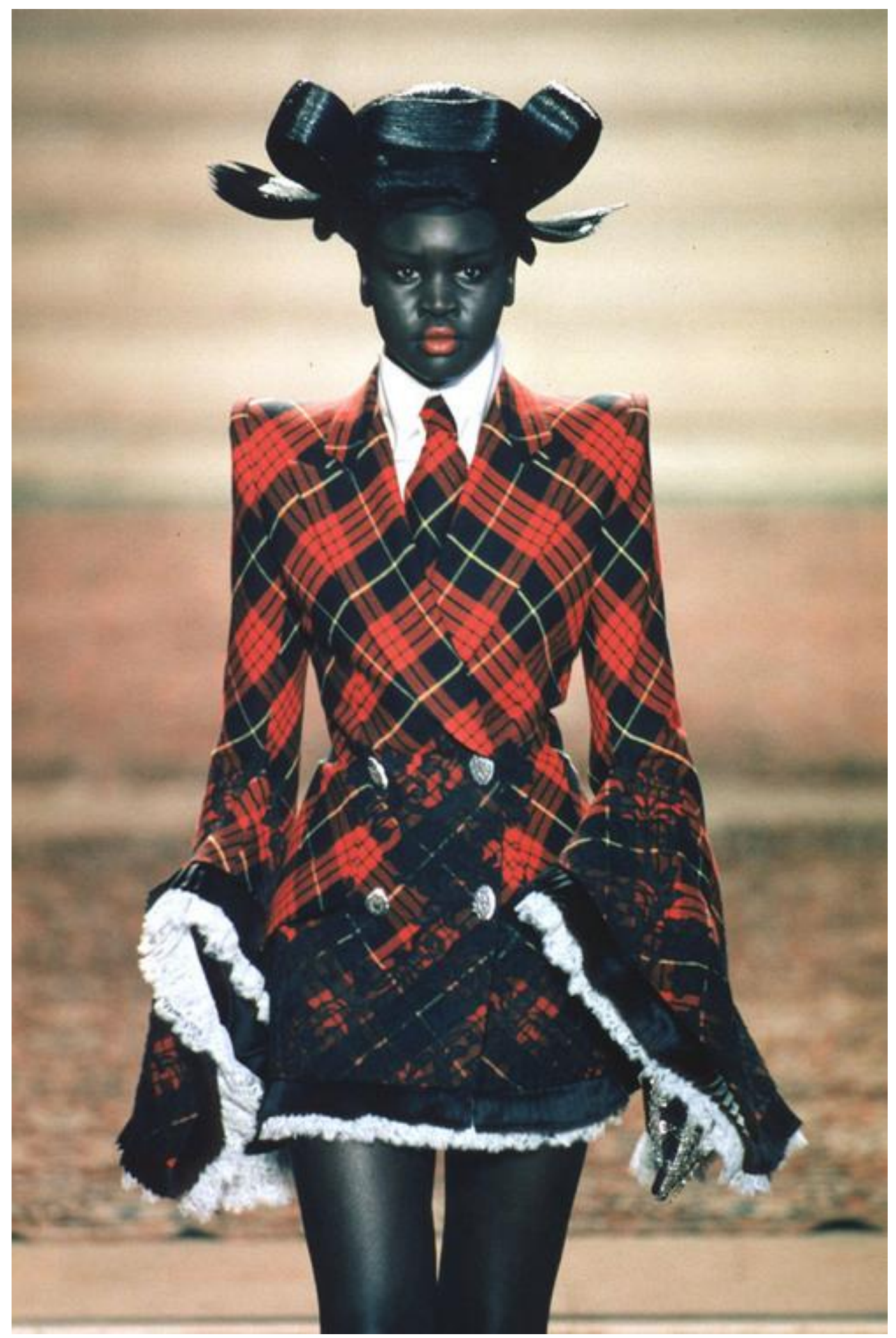

Placa 23a. Alexander McQueen. Colección Eclect Dissect. 


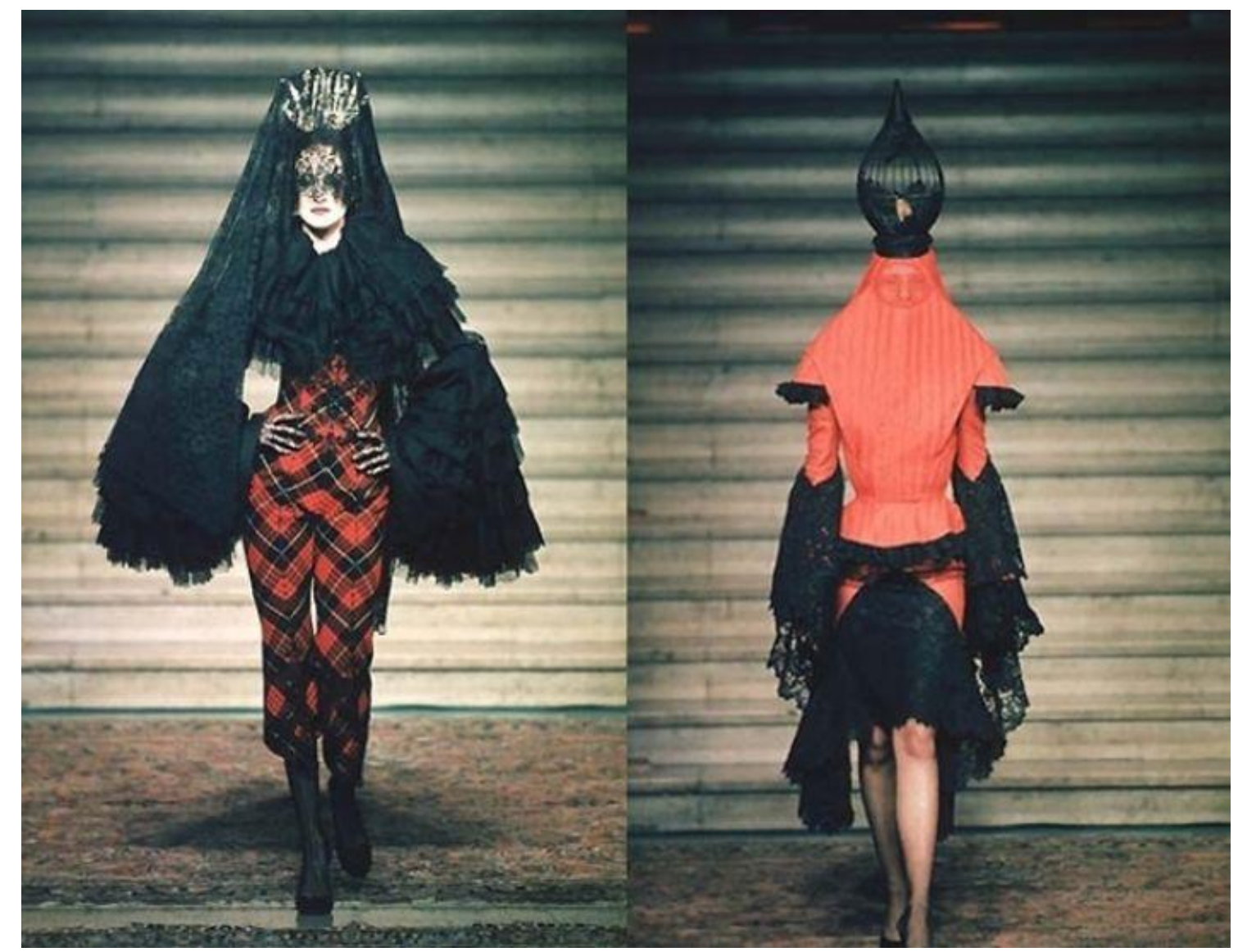

Placa 23b. Alexander McQueen. Colección Eclect Dissect. 


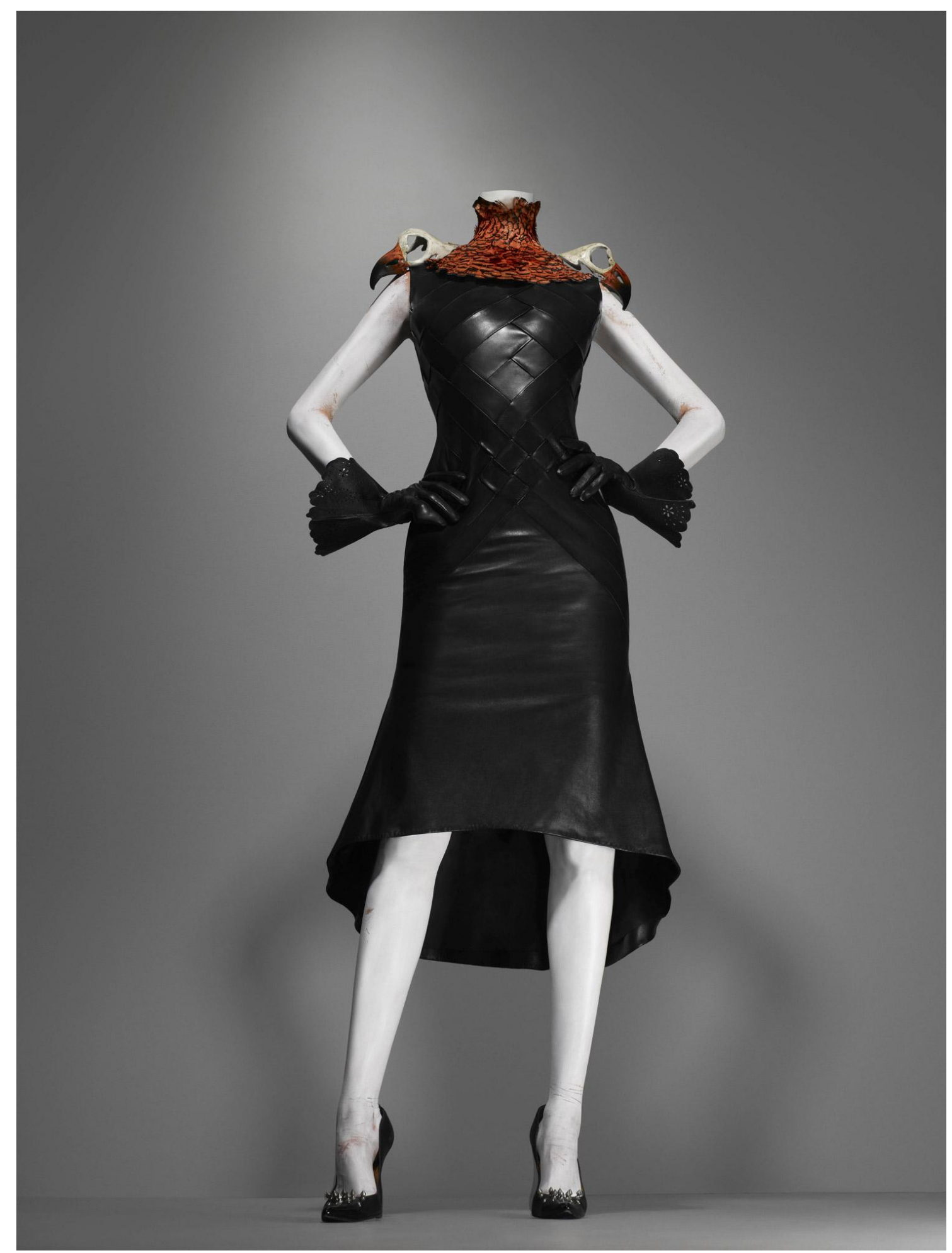

Placa 23c. Alexander McQueen. Colección Eclect Dissect. 

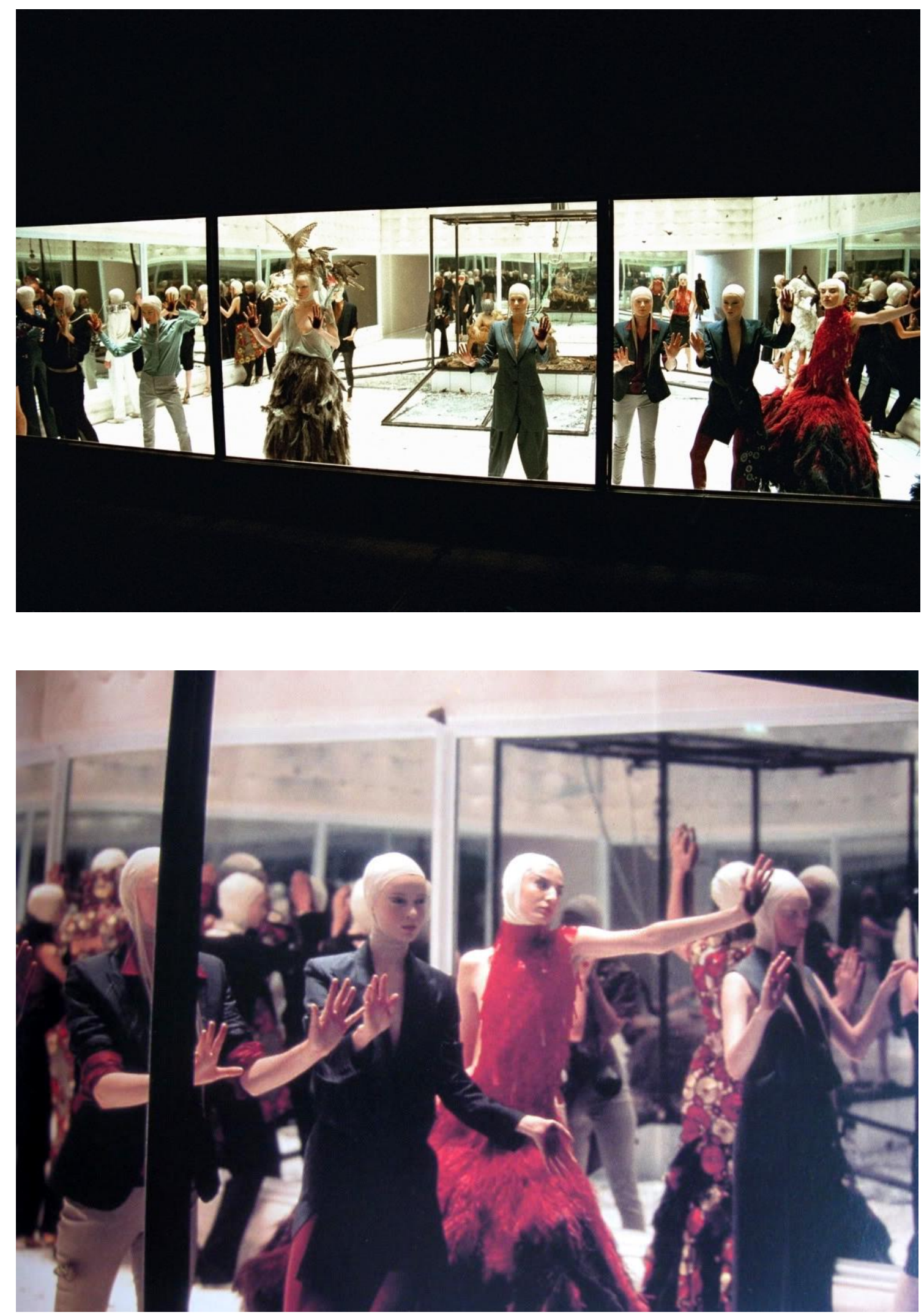

Placa 24. Alexander McQueen. Colección VOSS. 


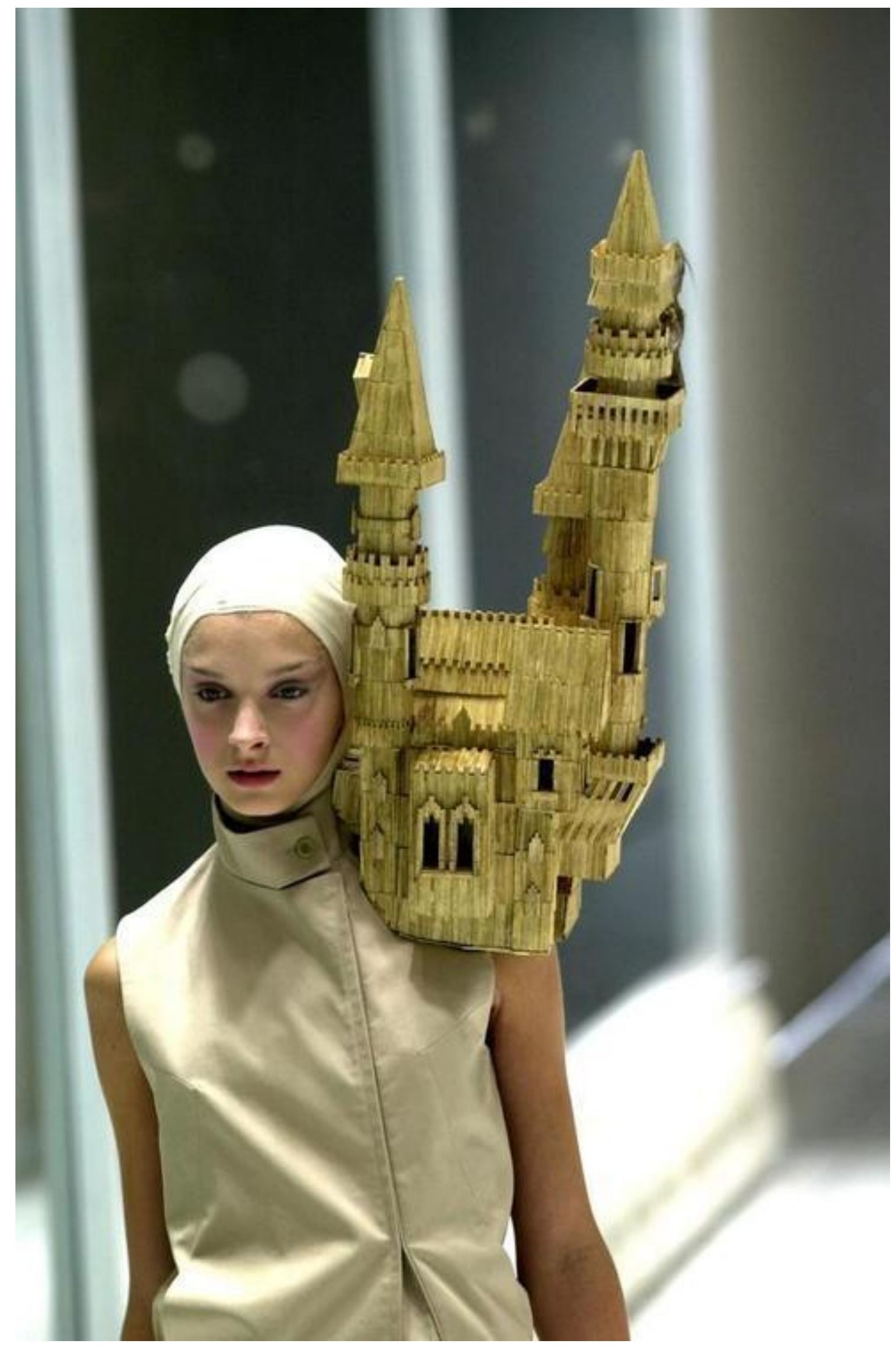

Placa 24a. Alexander McQueen. Colección VOSS. 


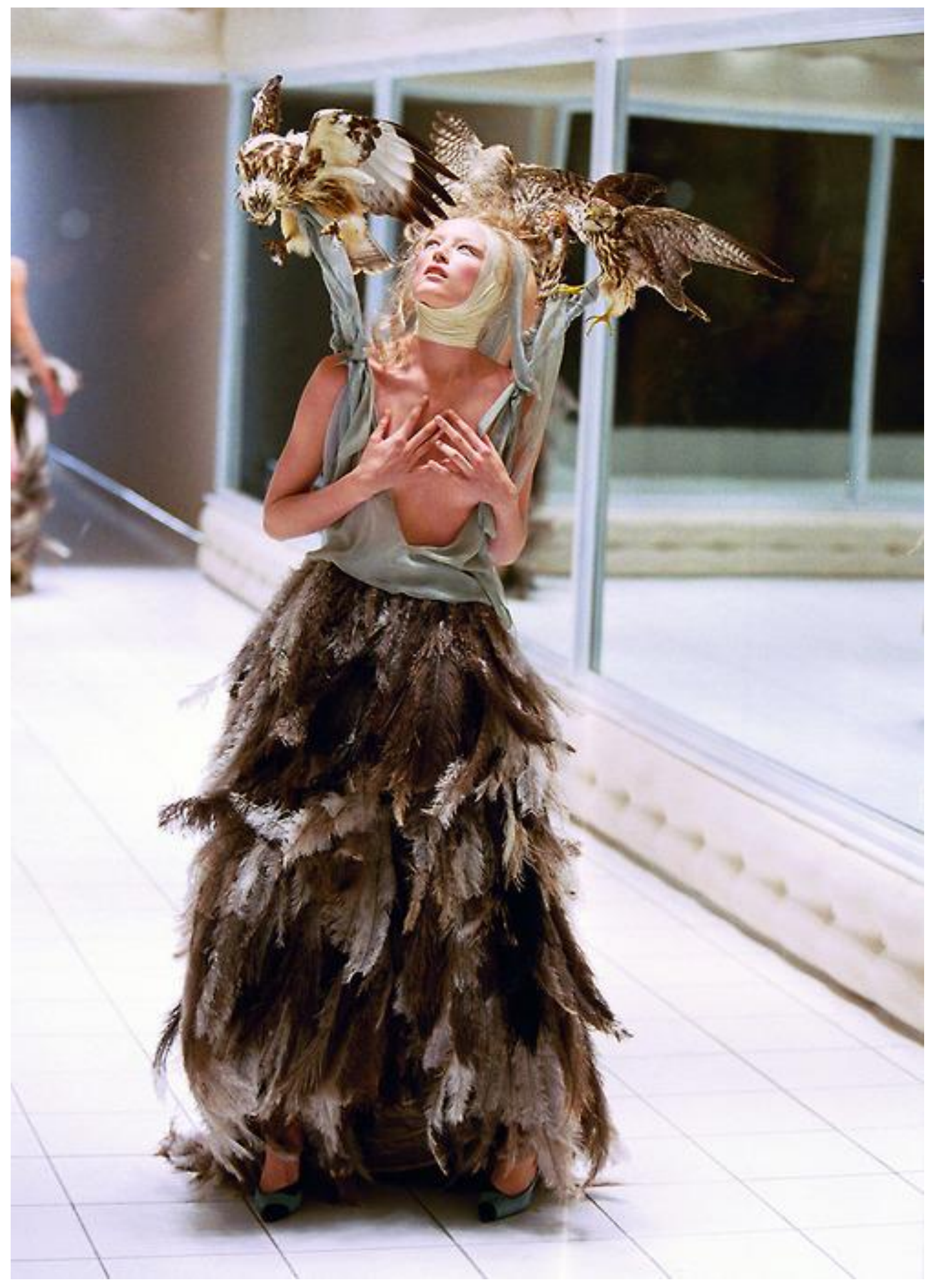

Placa 24b. Alexander McQueen. Colección VOSS. 


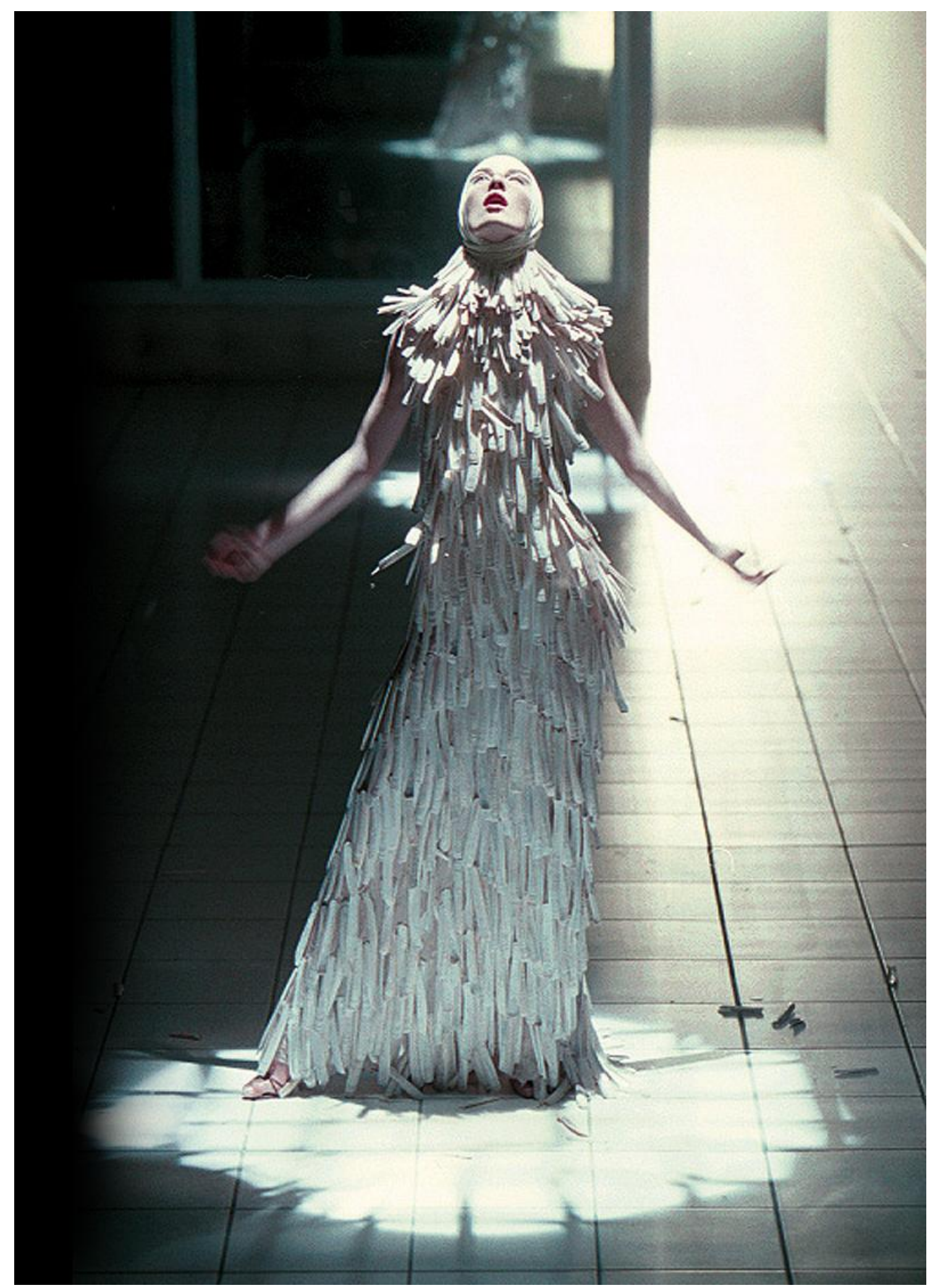

Placa 24c. Alexander McQueen. Colección VOSS. 


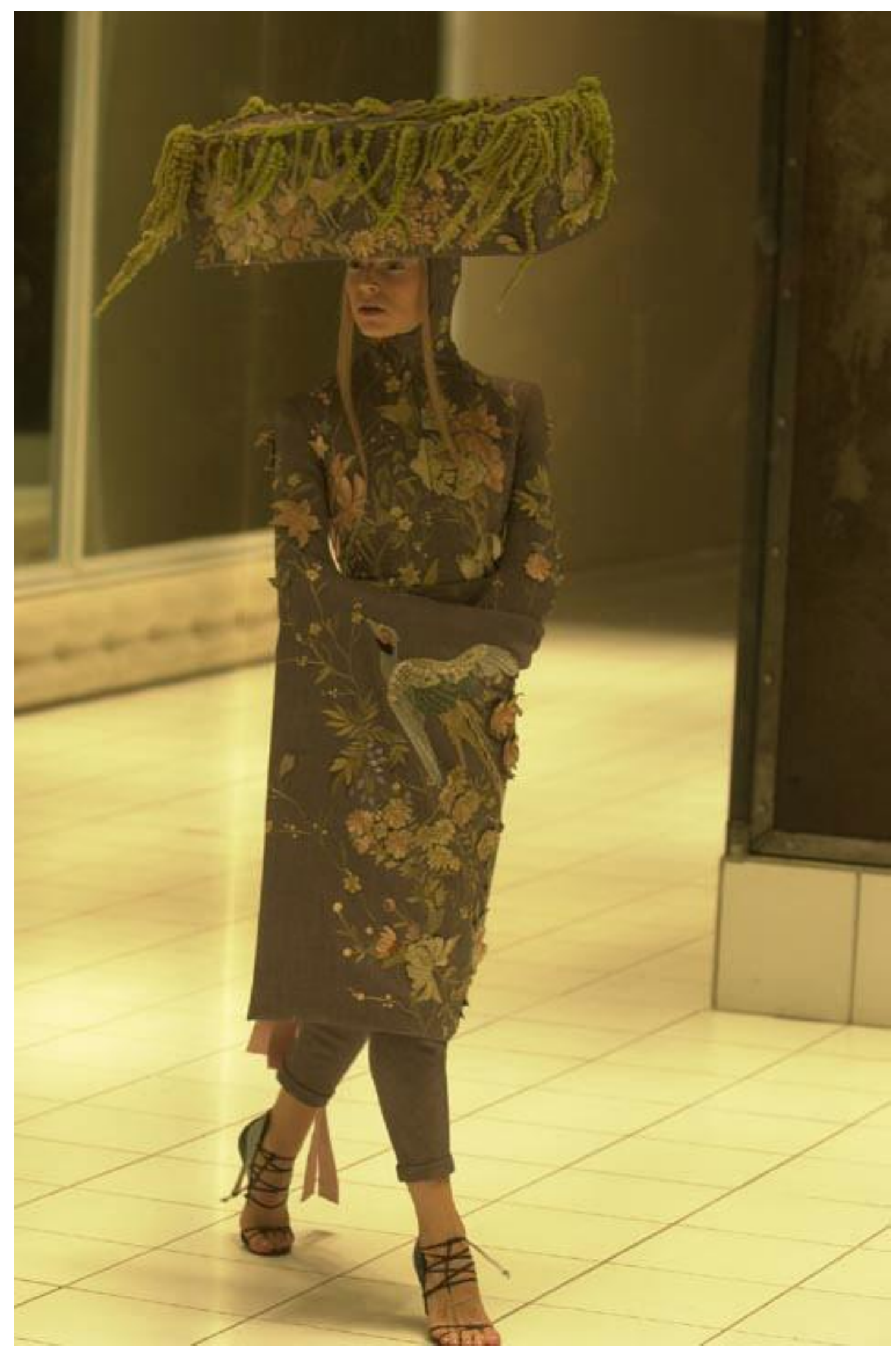

Placa 24d. Alexander McQueen. Colección VOSS. 


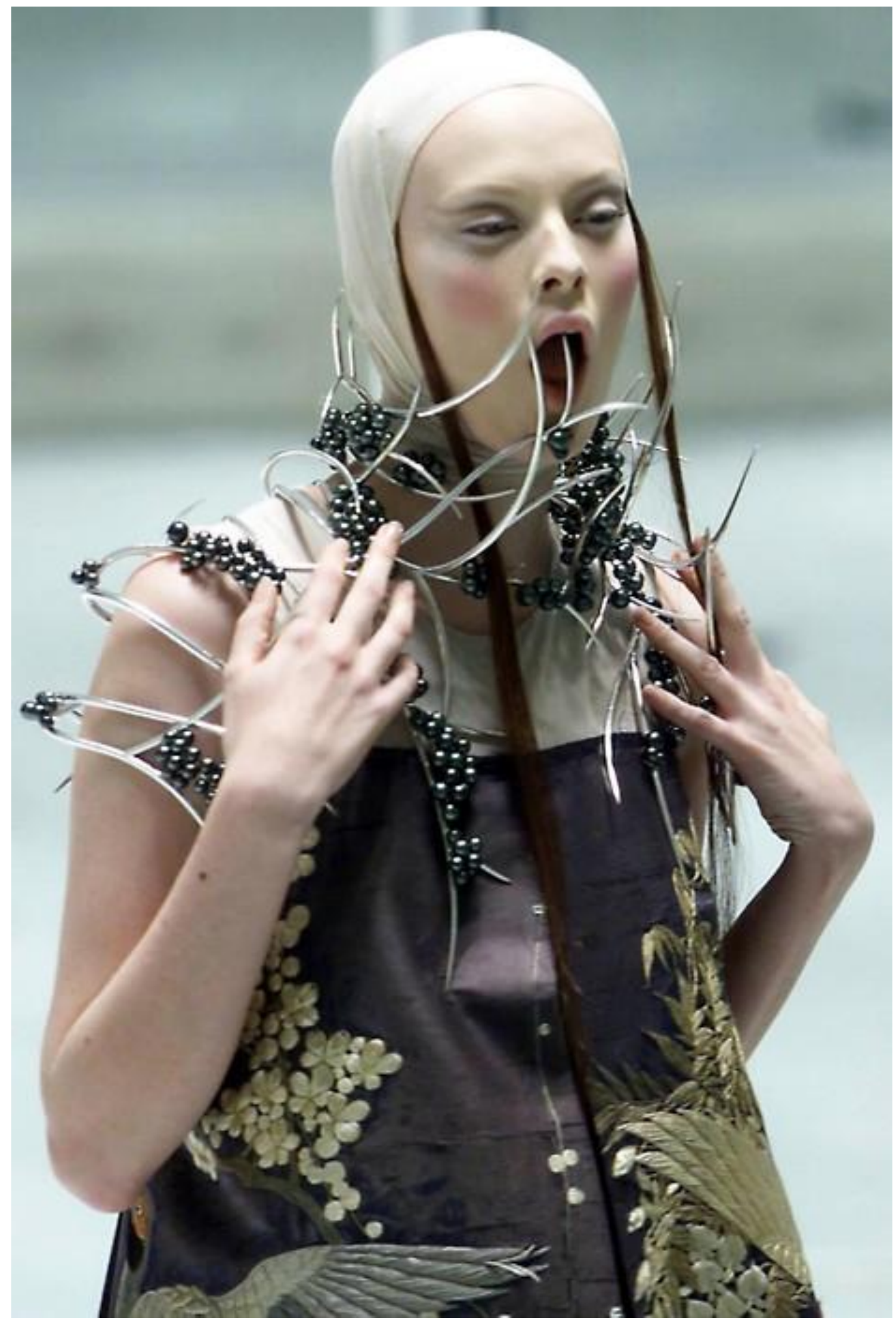

Placa 24e. Alexander McQueen. Colección VOSS. 

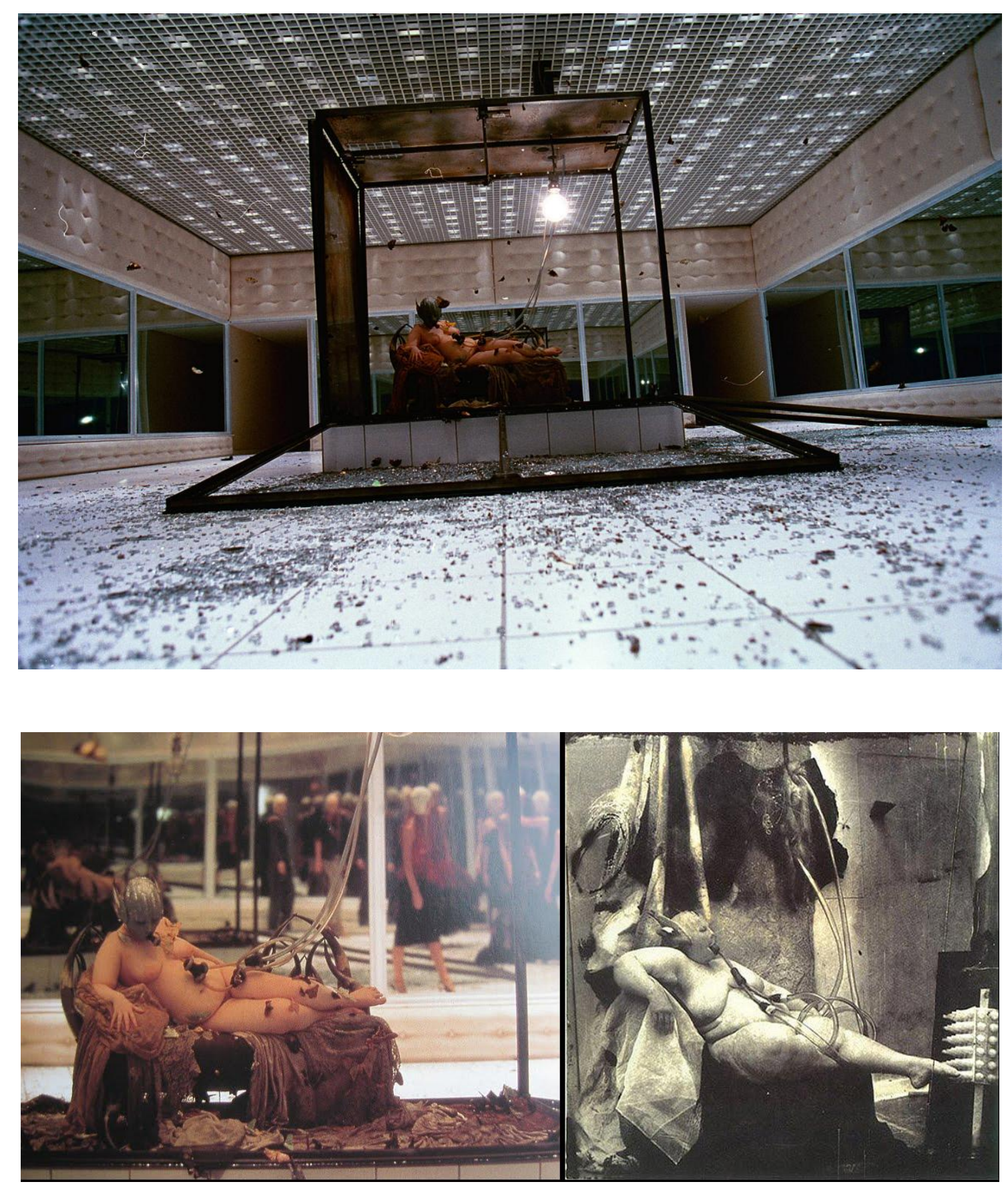

Placa 24f. Alexander McQueen. Colección VOSS. 


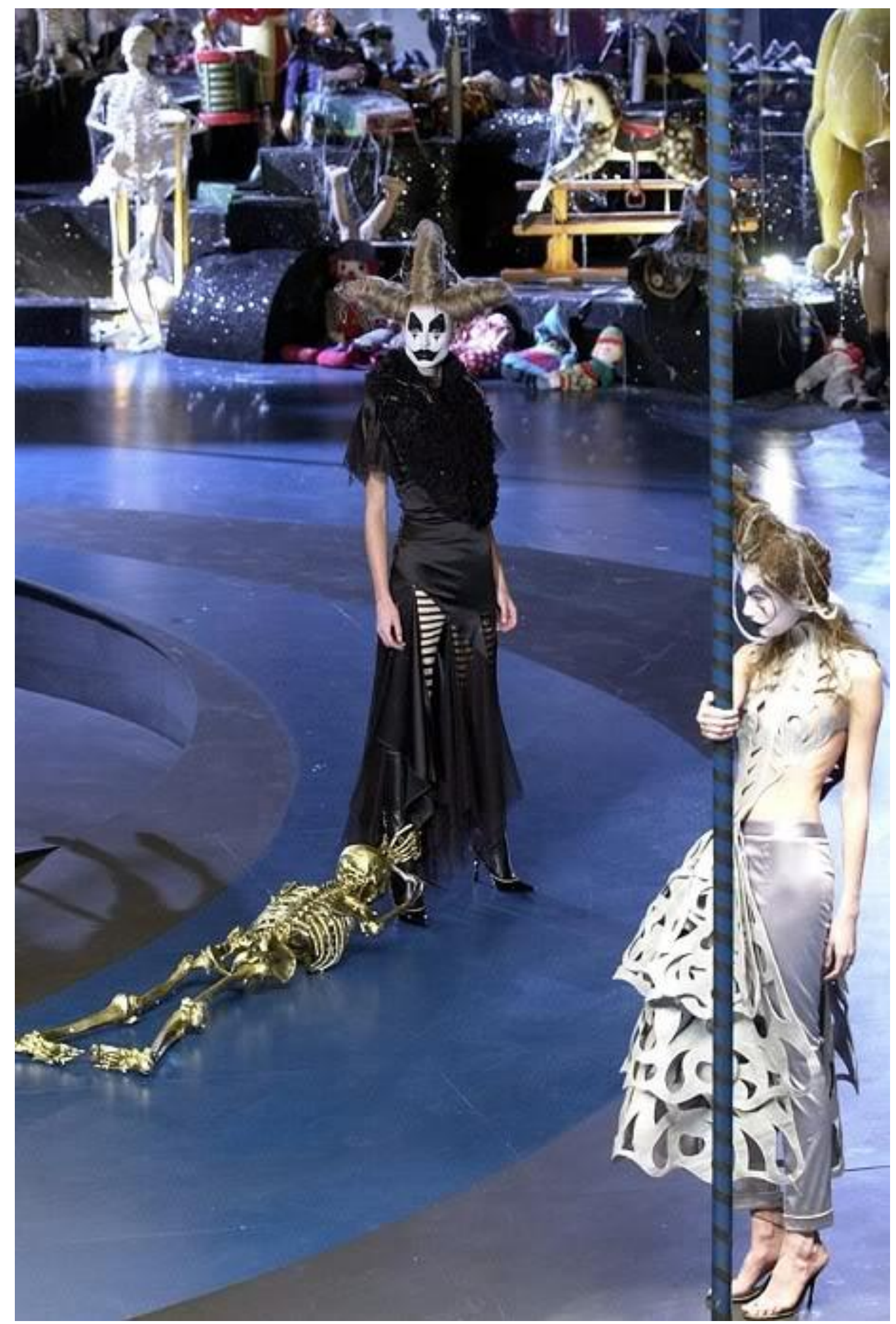

Placa 25. Alexander McQueen. Colección What A Merry-Go-Round. 


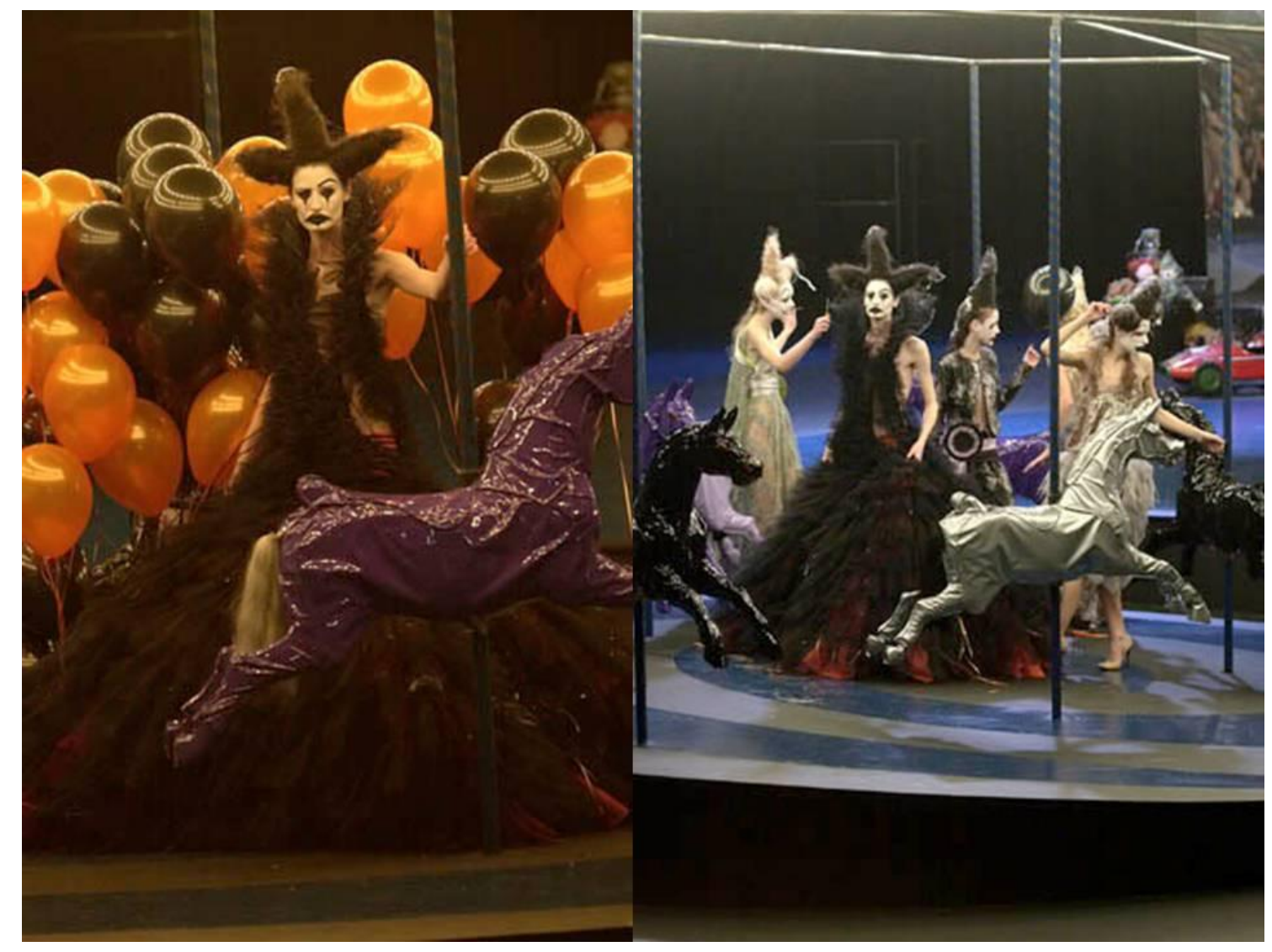

Placa 25a. Alexander McQueen. Colección What A Merry-Go-Round. 


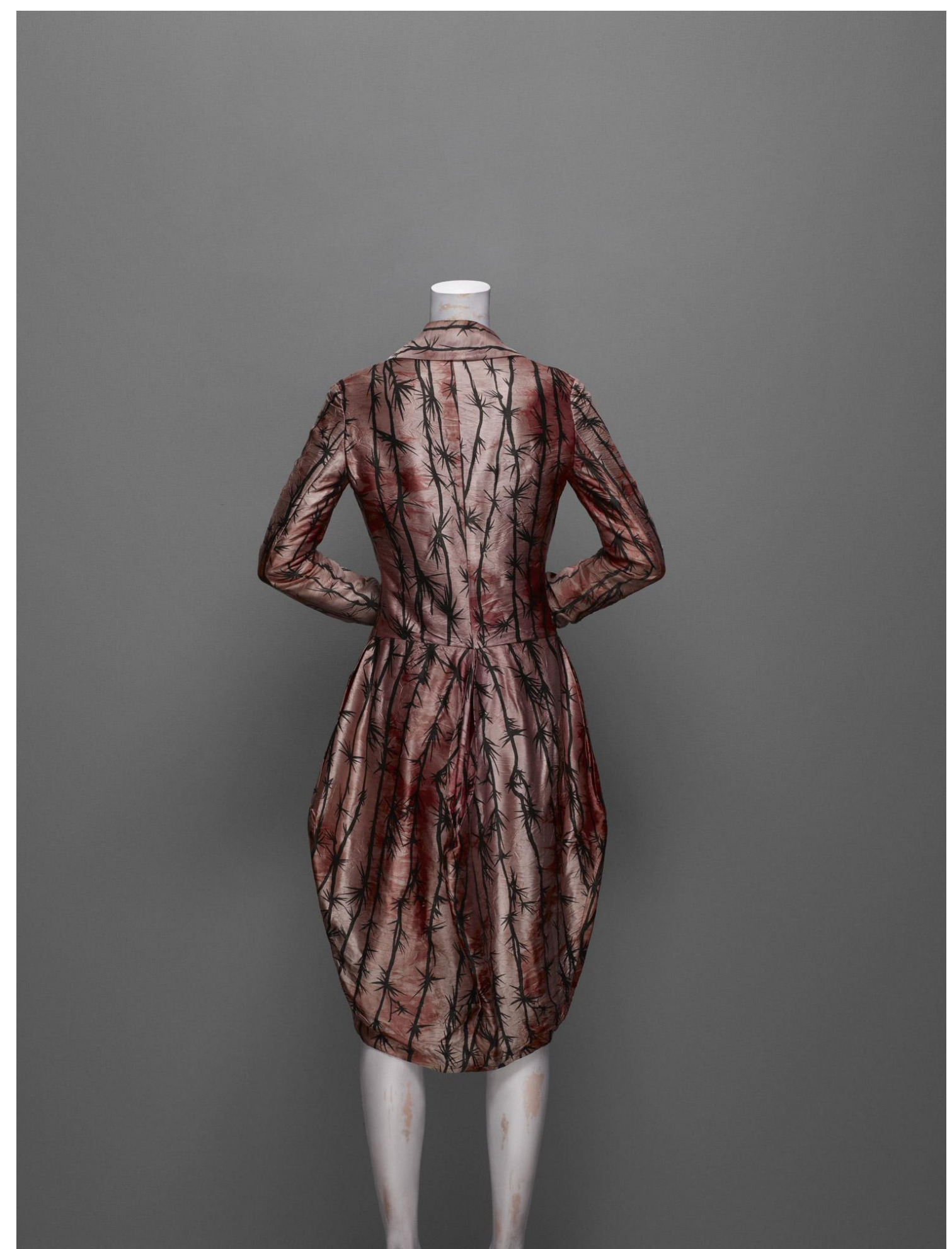

Placa 26. Alexander McQueen. Colección Jack The Ripper Stalks His Victims. 


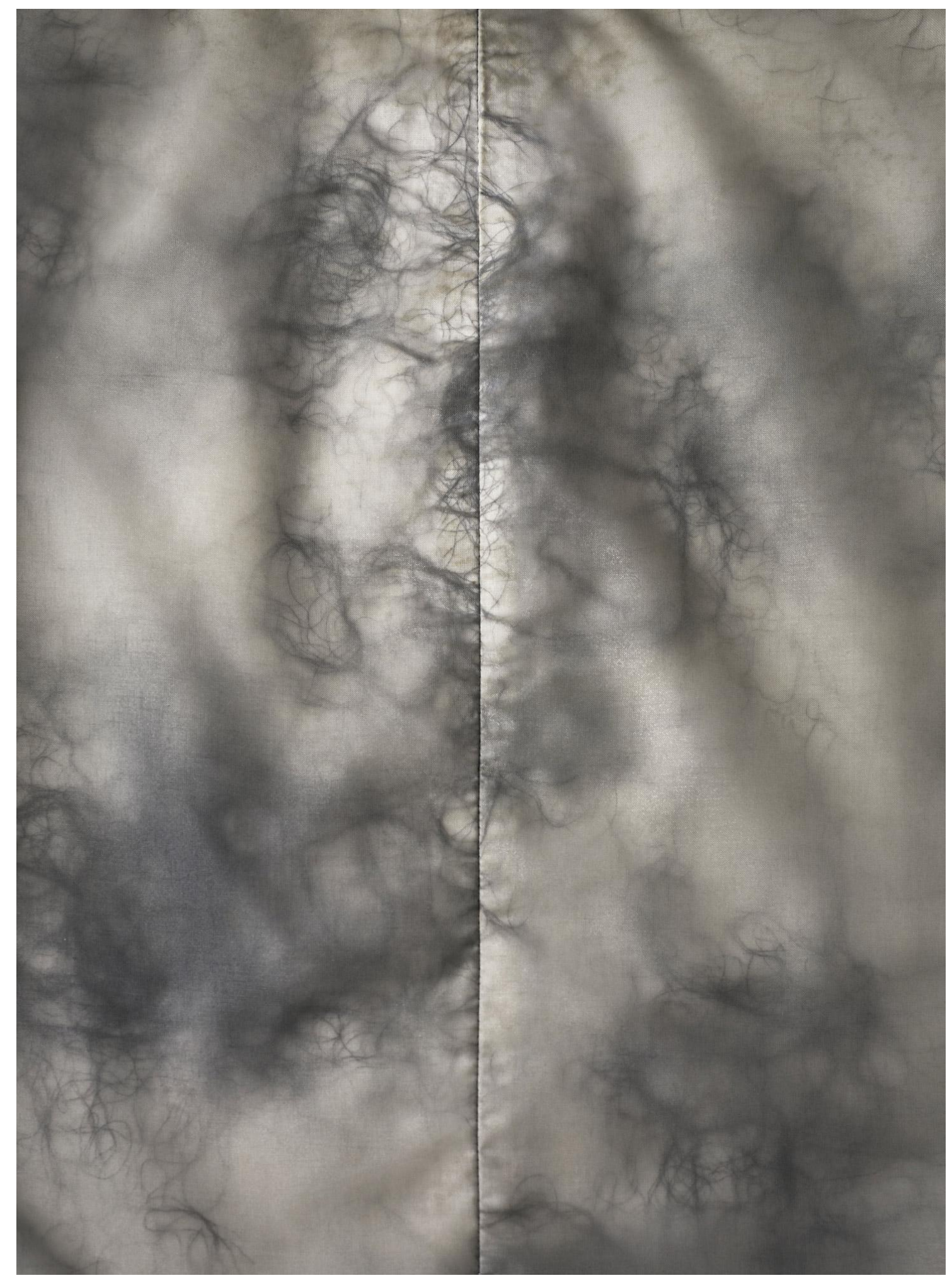

Placa 26a. Alexander McQueen. Colección Jack The Ripper Stalks His Victims. 


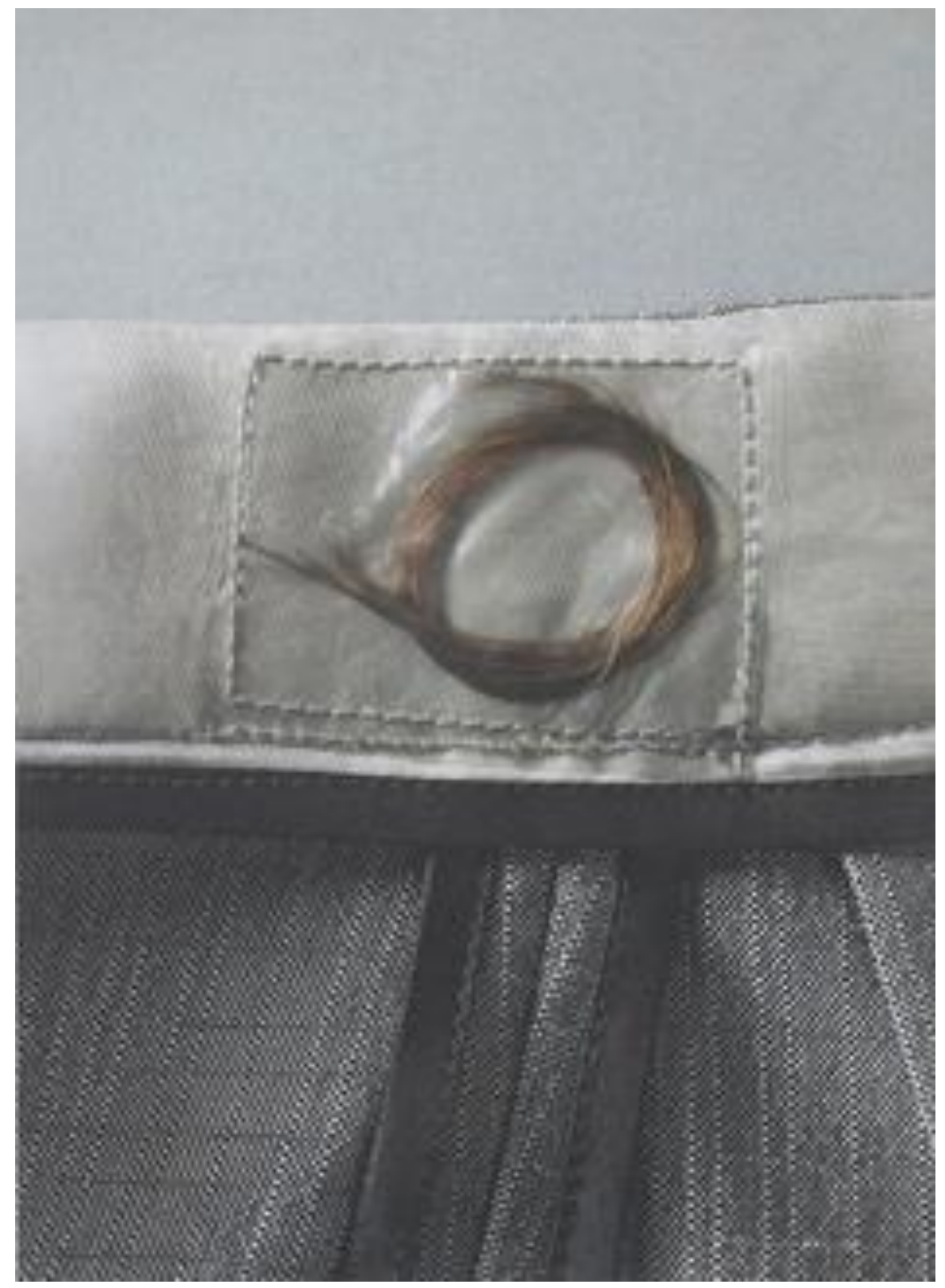

Placa 26b. Alexander McQueen. Colección Jack The Ripper Stalks His Victims. 


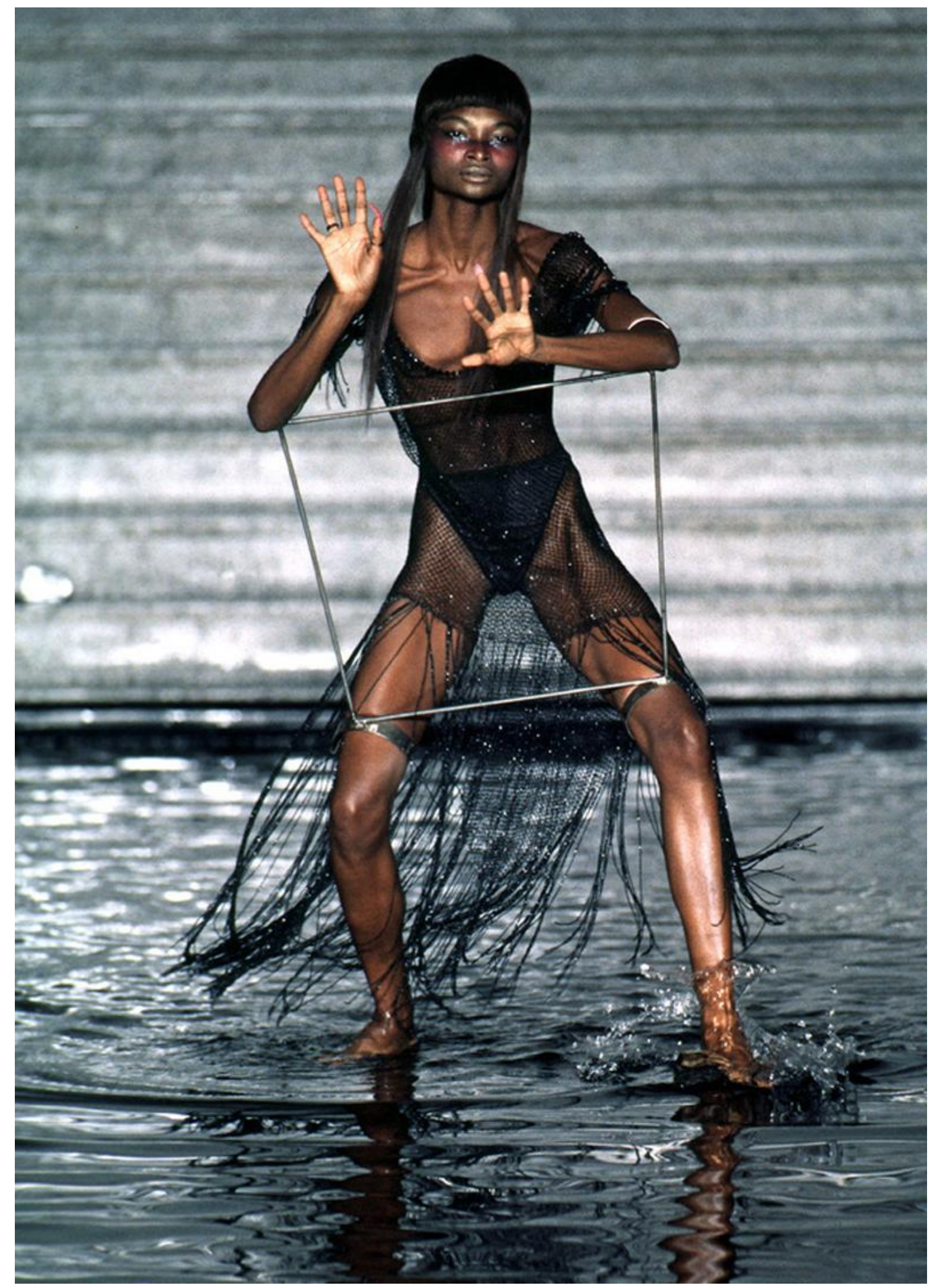

Placa 27. Alexander McQueen. Colección La Pouppée. 


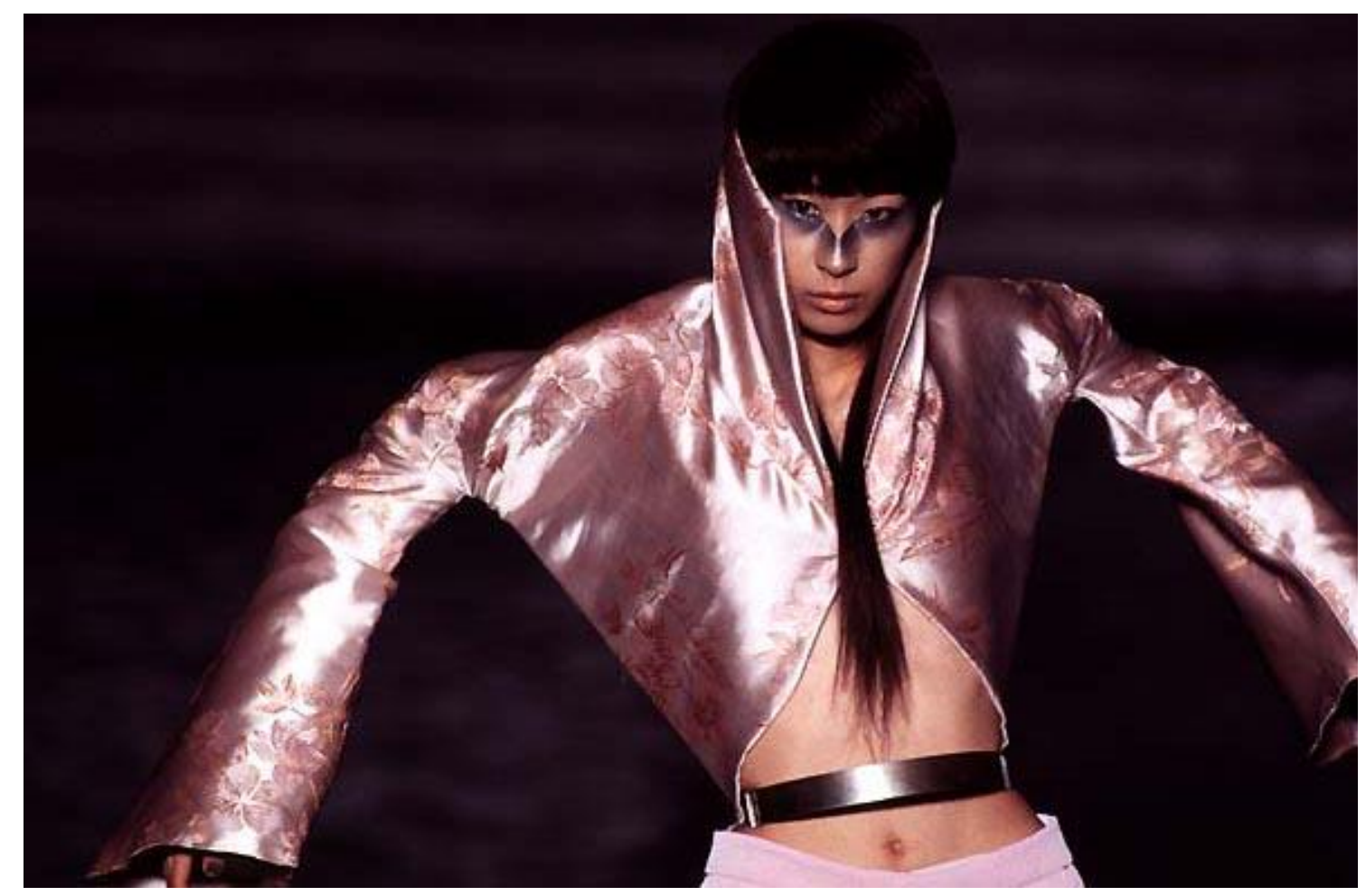

Placa 27a. Alexander McQueen. Colección La Pouppée. 


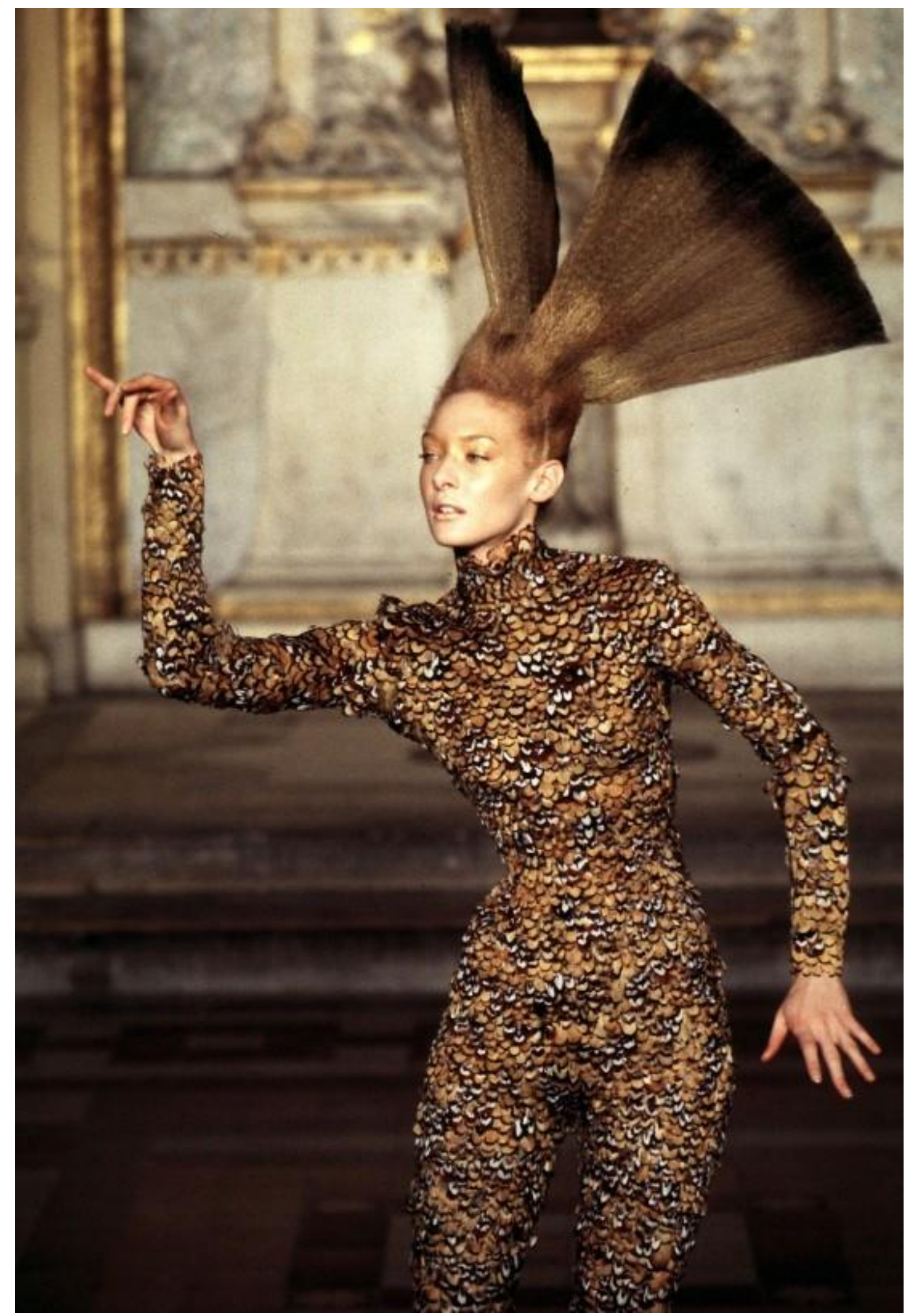

Placa 27b. Alexander McQueen. Colección La Pouppée. 


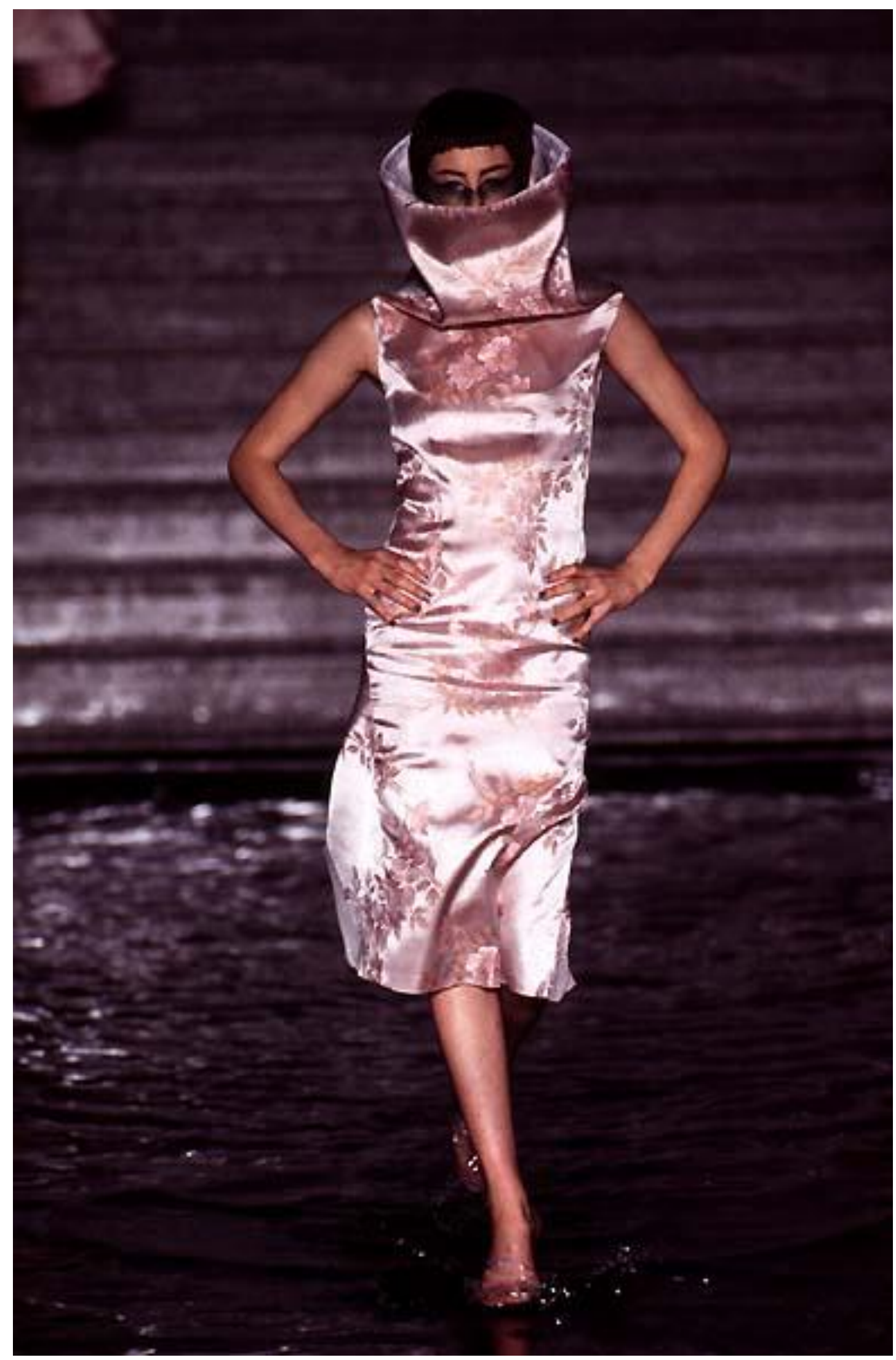

Placa 27. Alexander McQueen. Colección La Pouppée. 


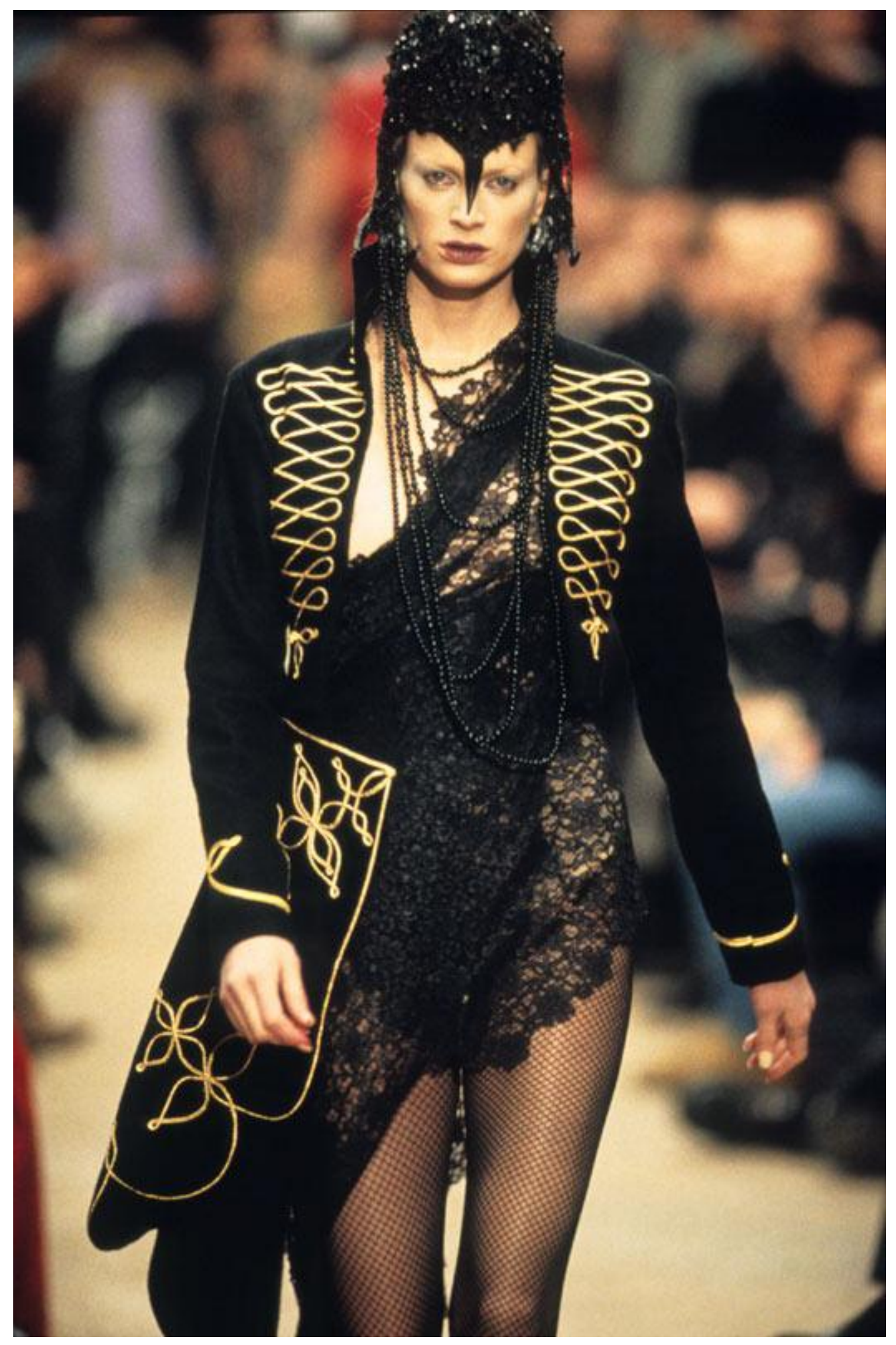

Placa 28. Alexander McQueen. Colección Dante. 


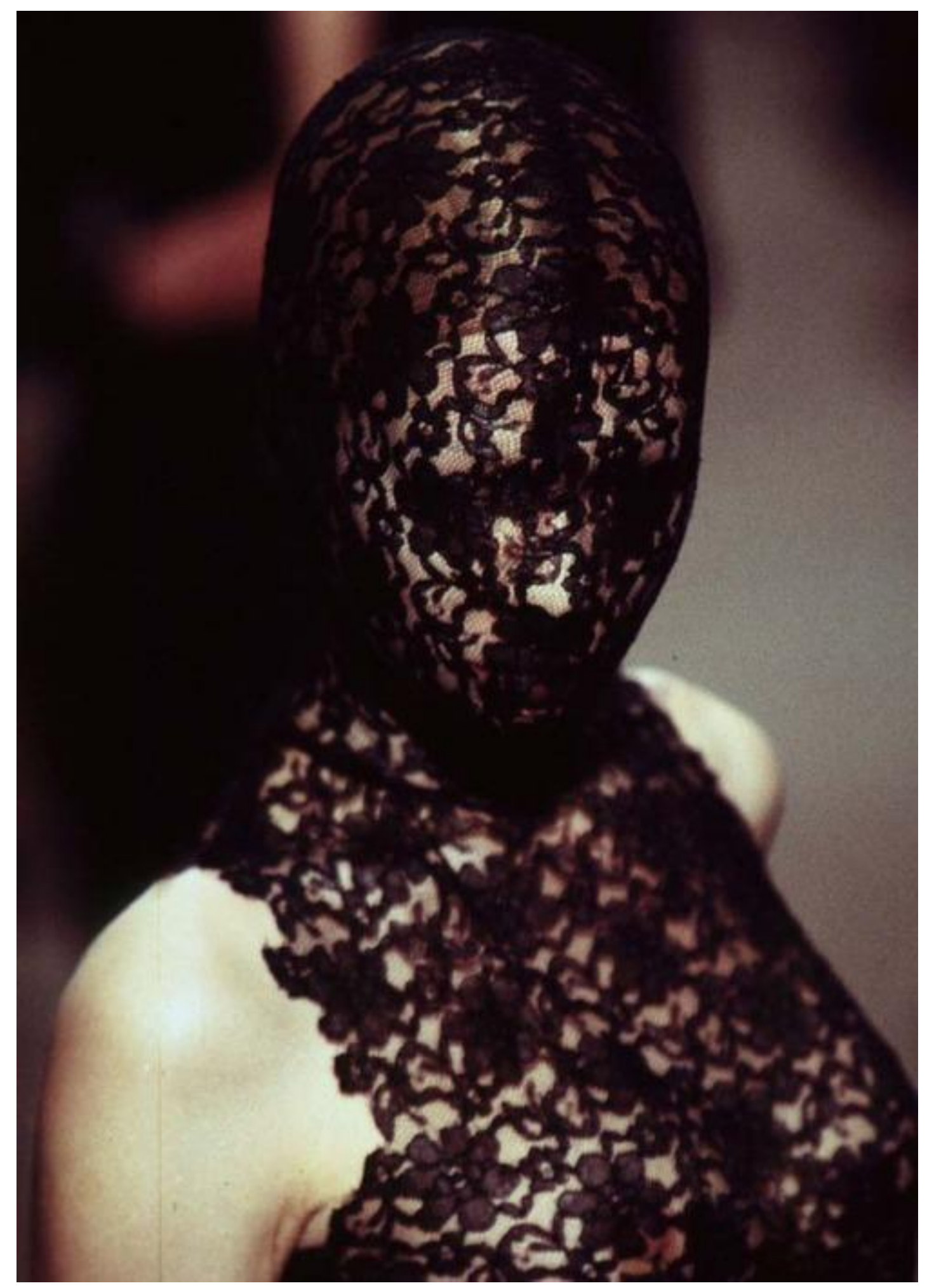

Placa 28a. Alexander McQueen. Colección Dante. 


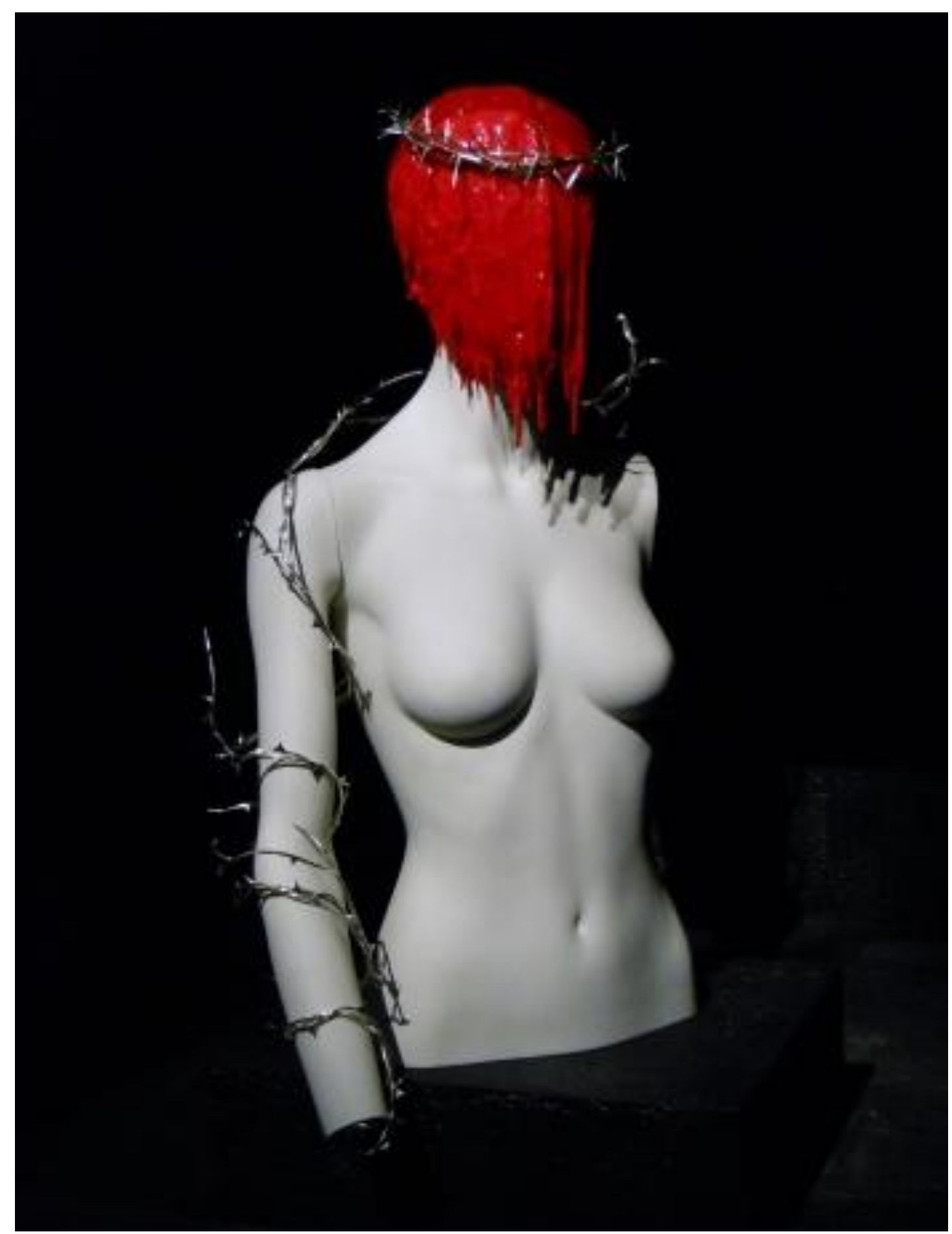

Placa 28b. Alexander McQueen. Colección Dante. 


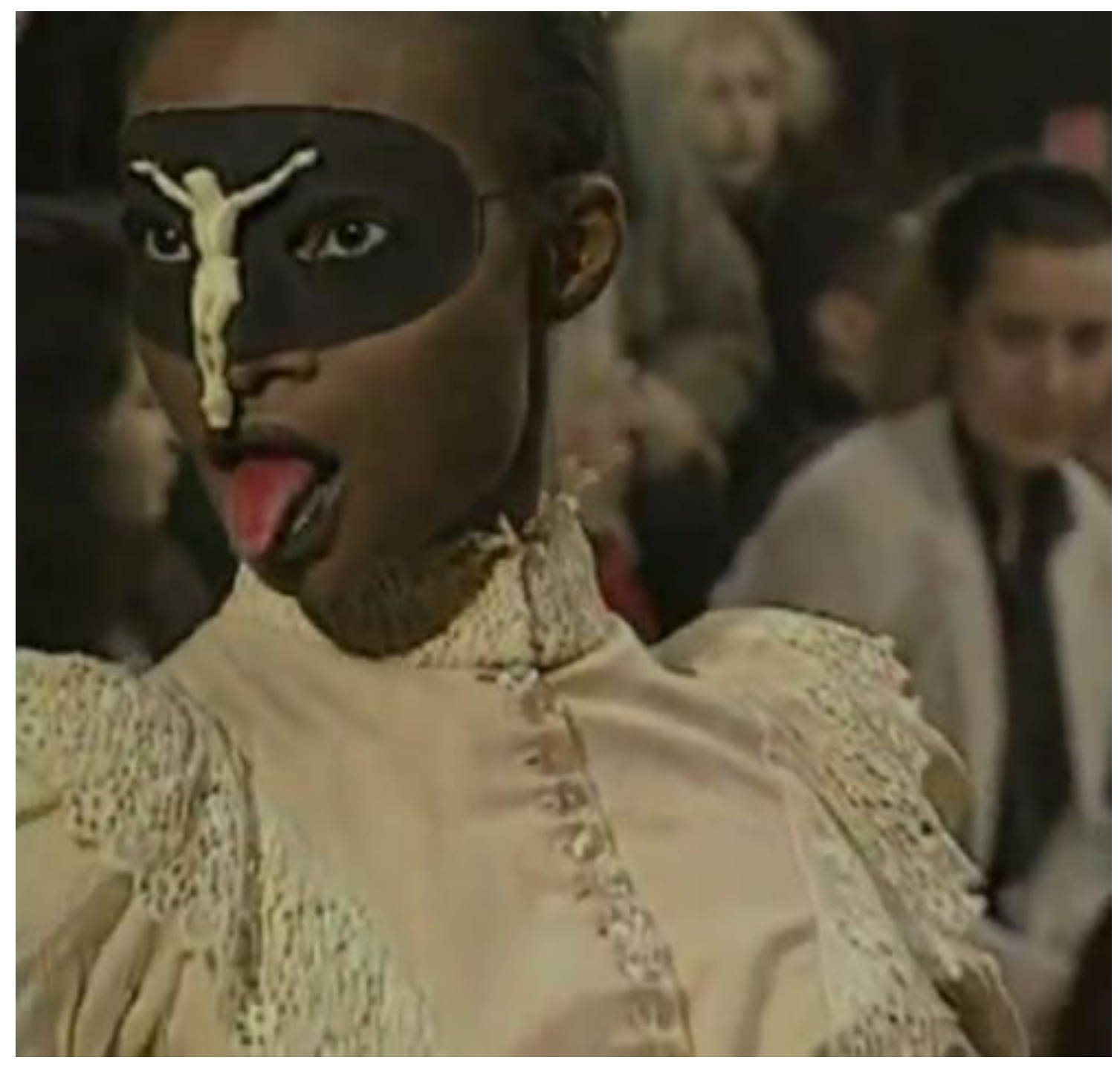

Placa 28c. Alexander McQueen. Colección Dante. 


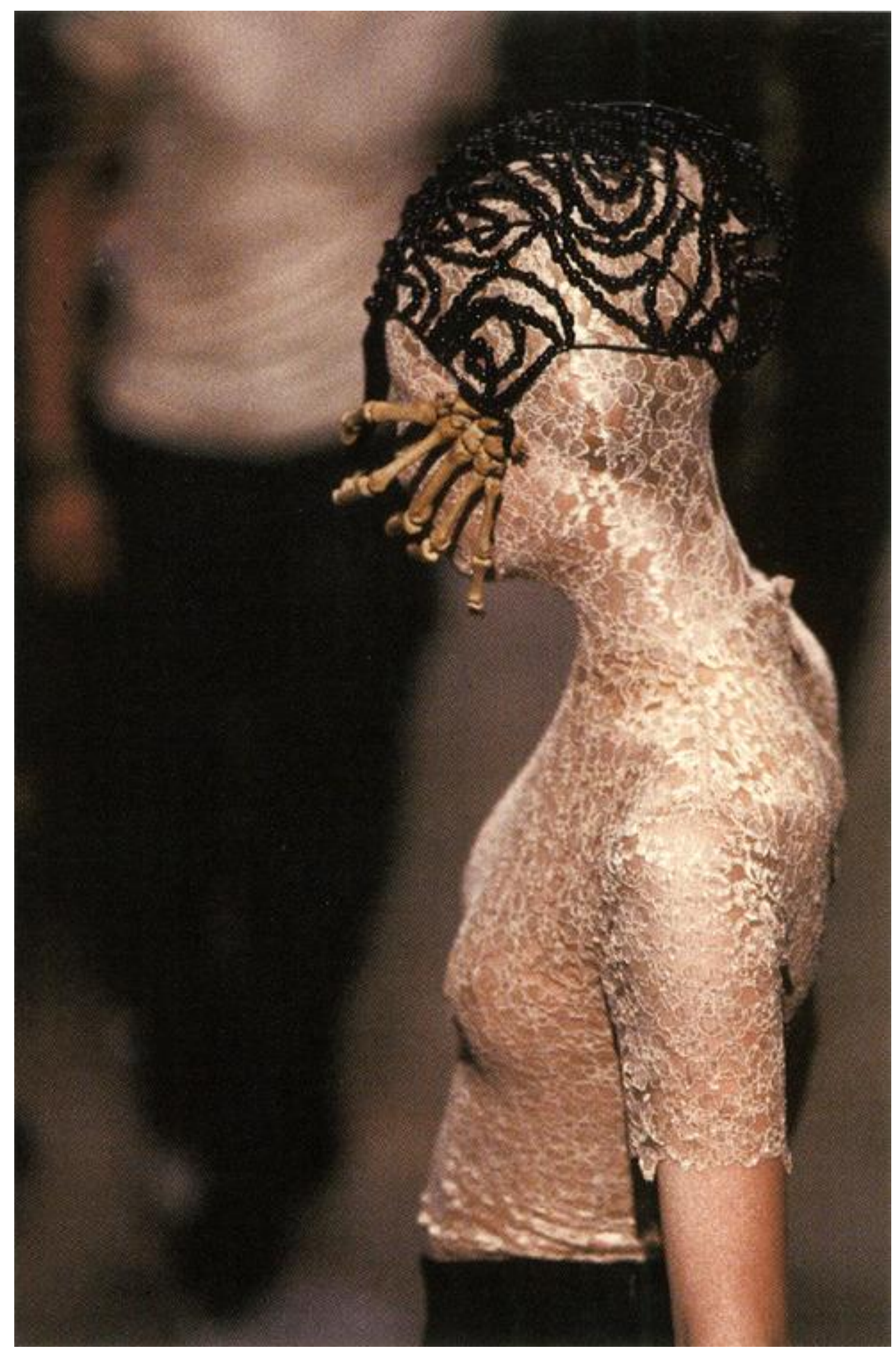

Placa 28d. Alexander McQueen. Colección Dante. 


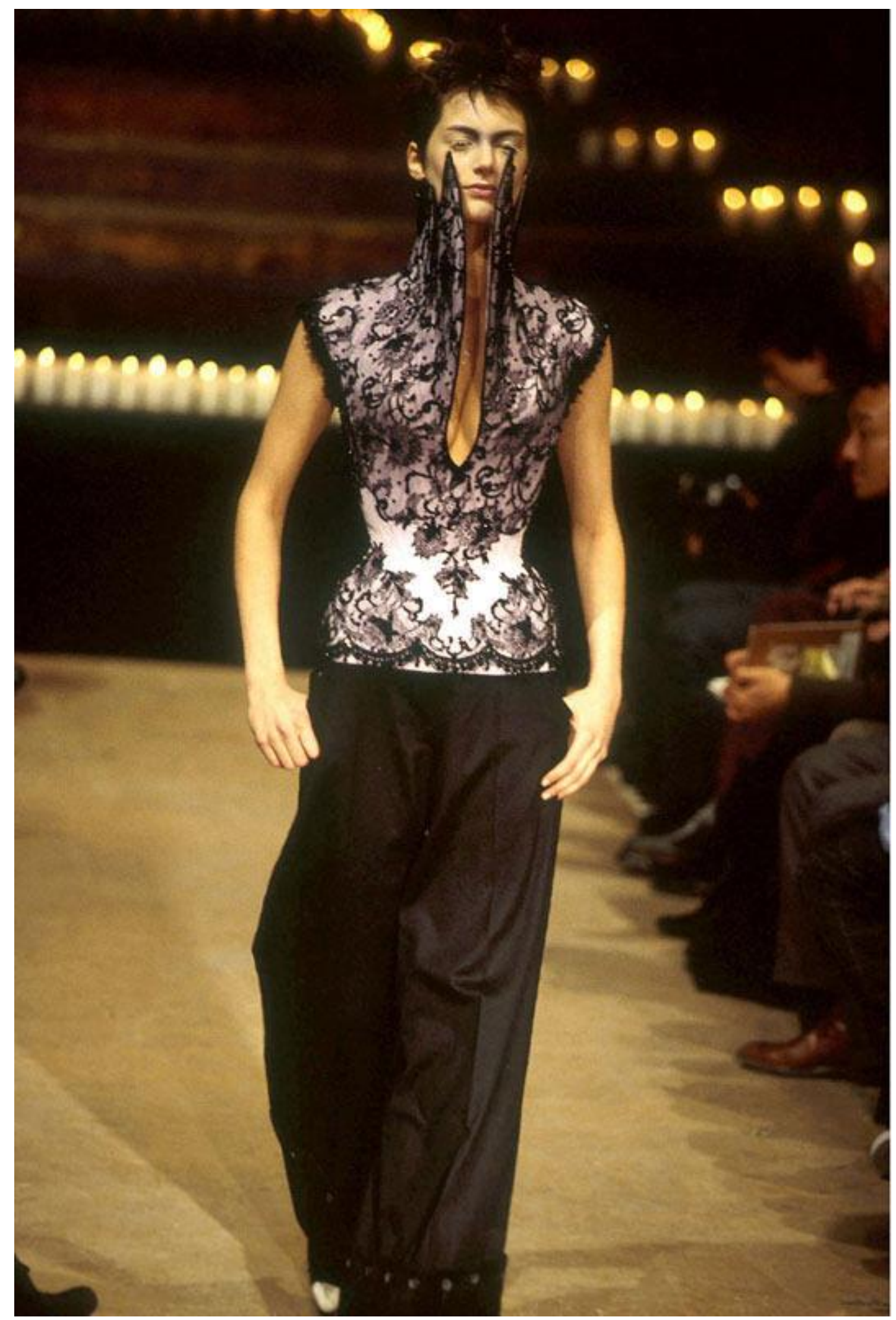

Placa 28e. Alexander McQueen. Colección Dante. 


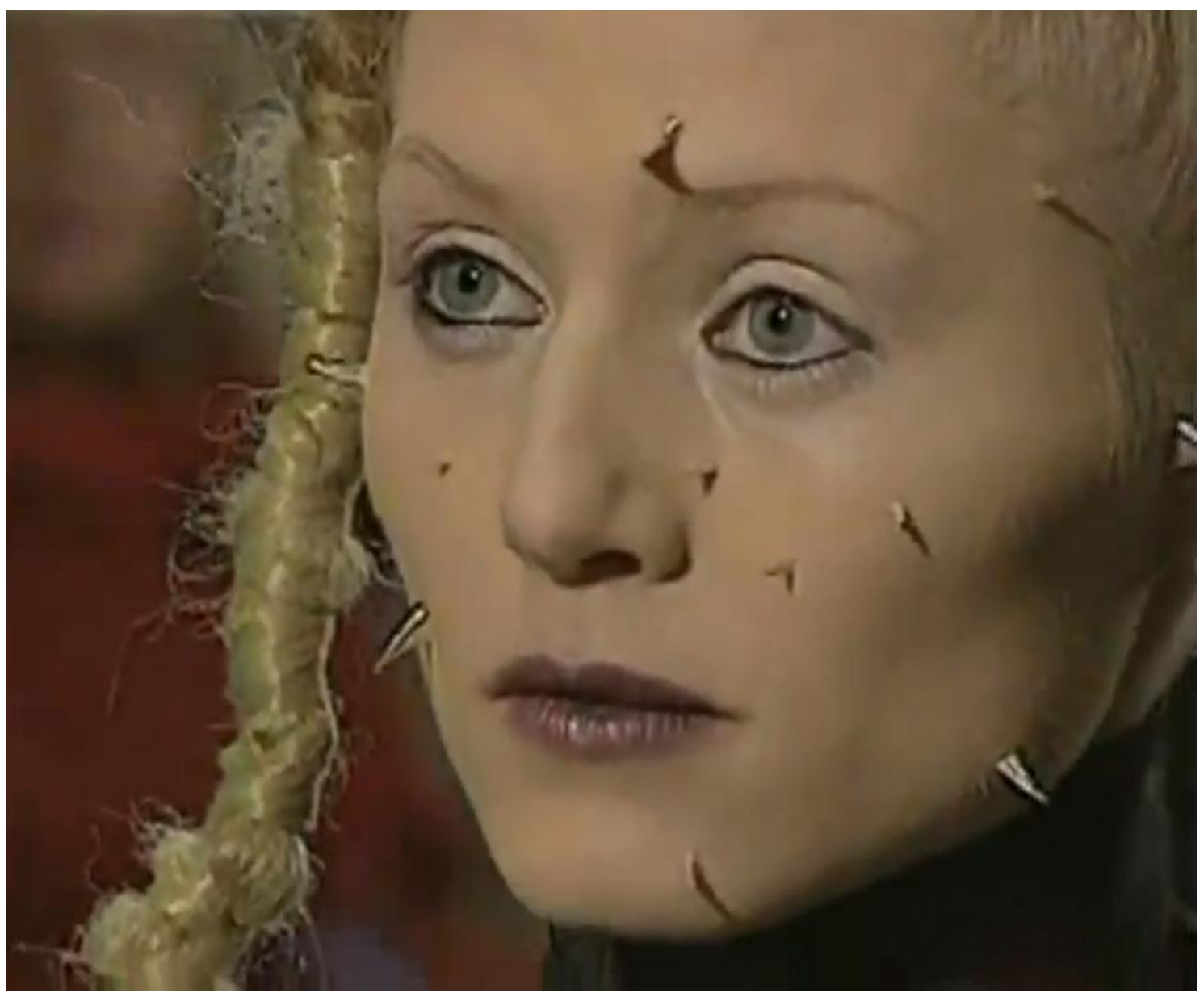

Placa 28f. Alexander McQueen. Colección Dante. 


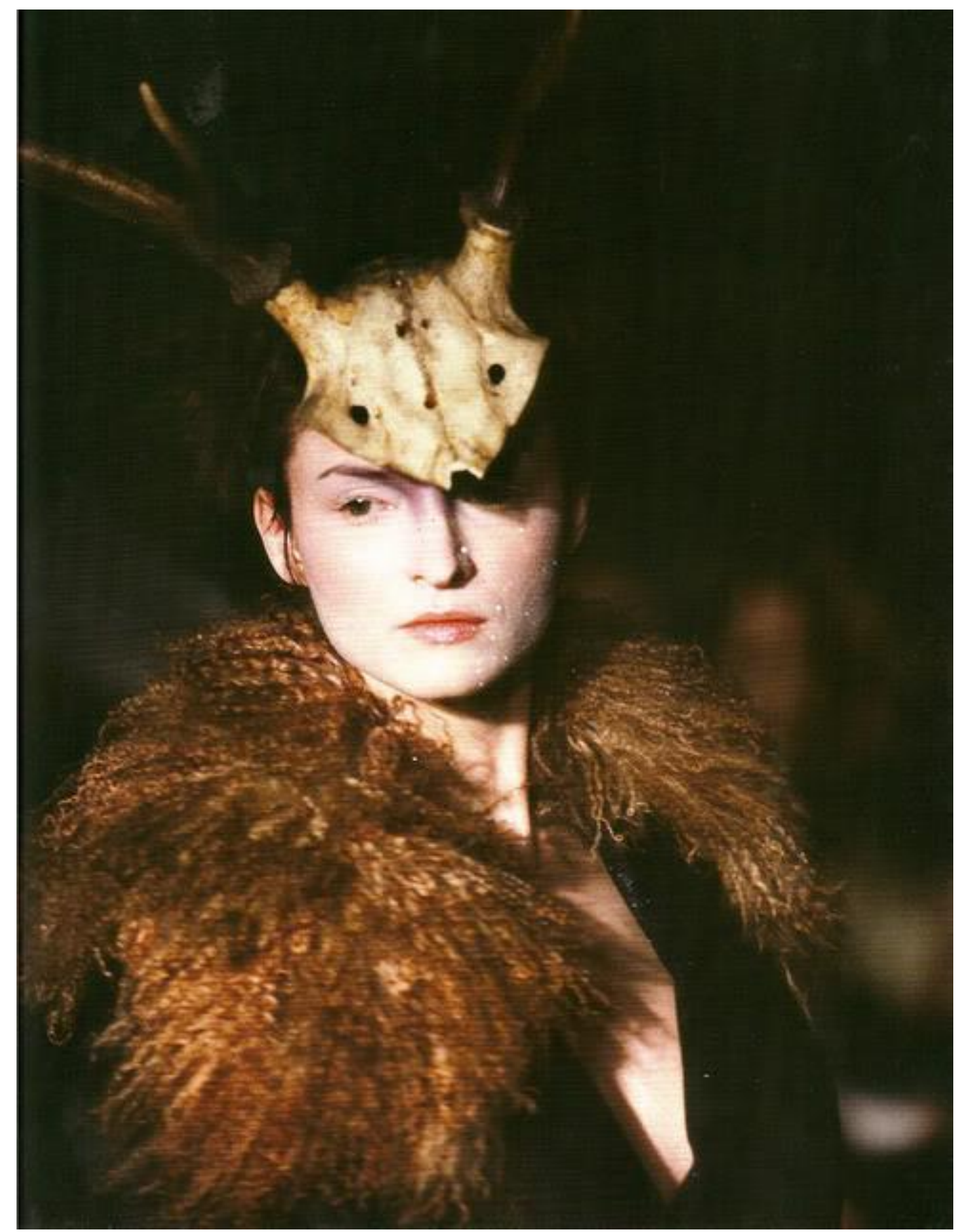

Placa 28. Alexander McQueen. Colección Dante. 


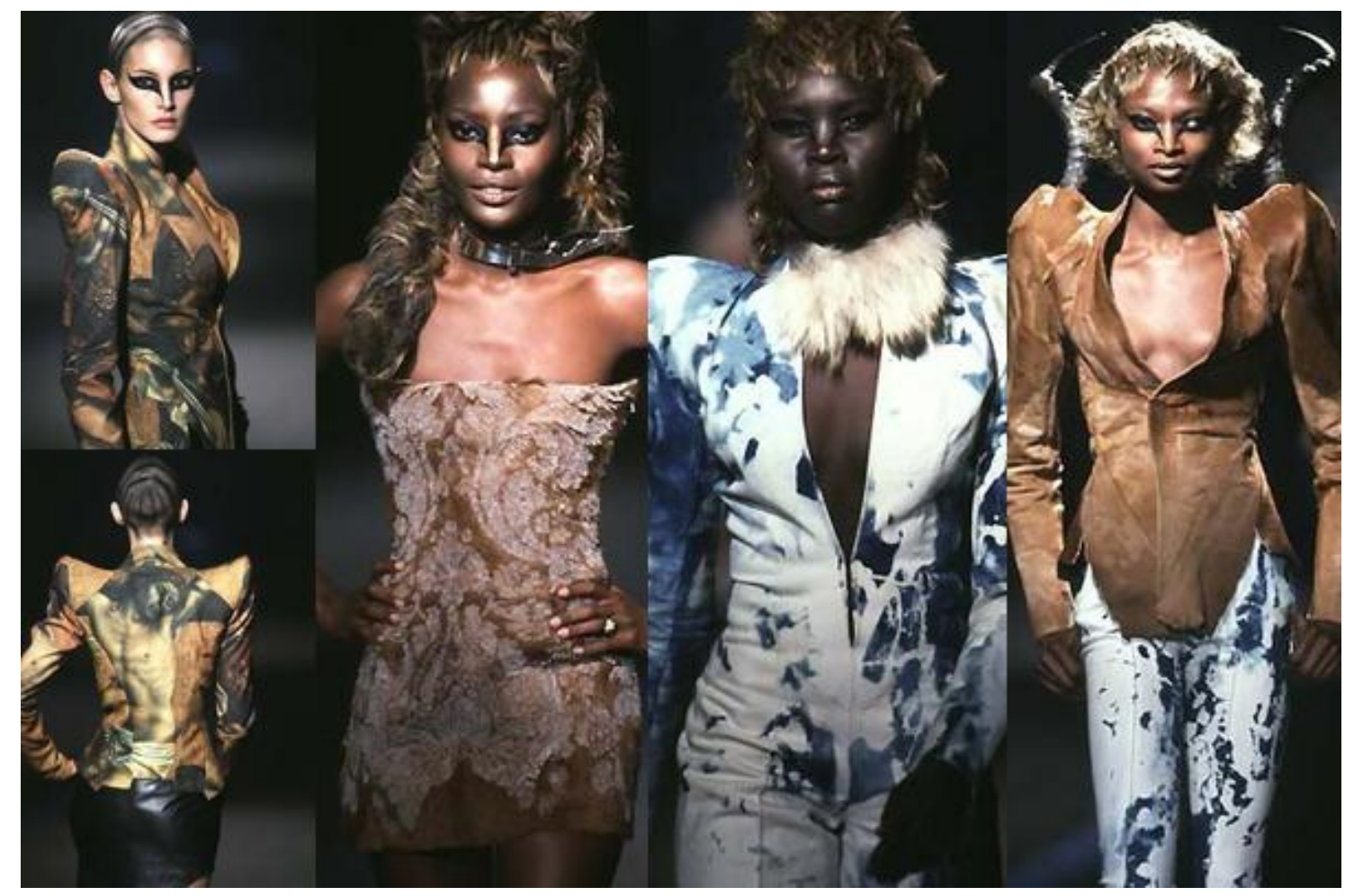

Placa 29. Alexander McQueen. Colección It's a Jungle Out There. 


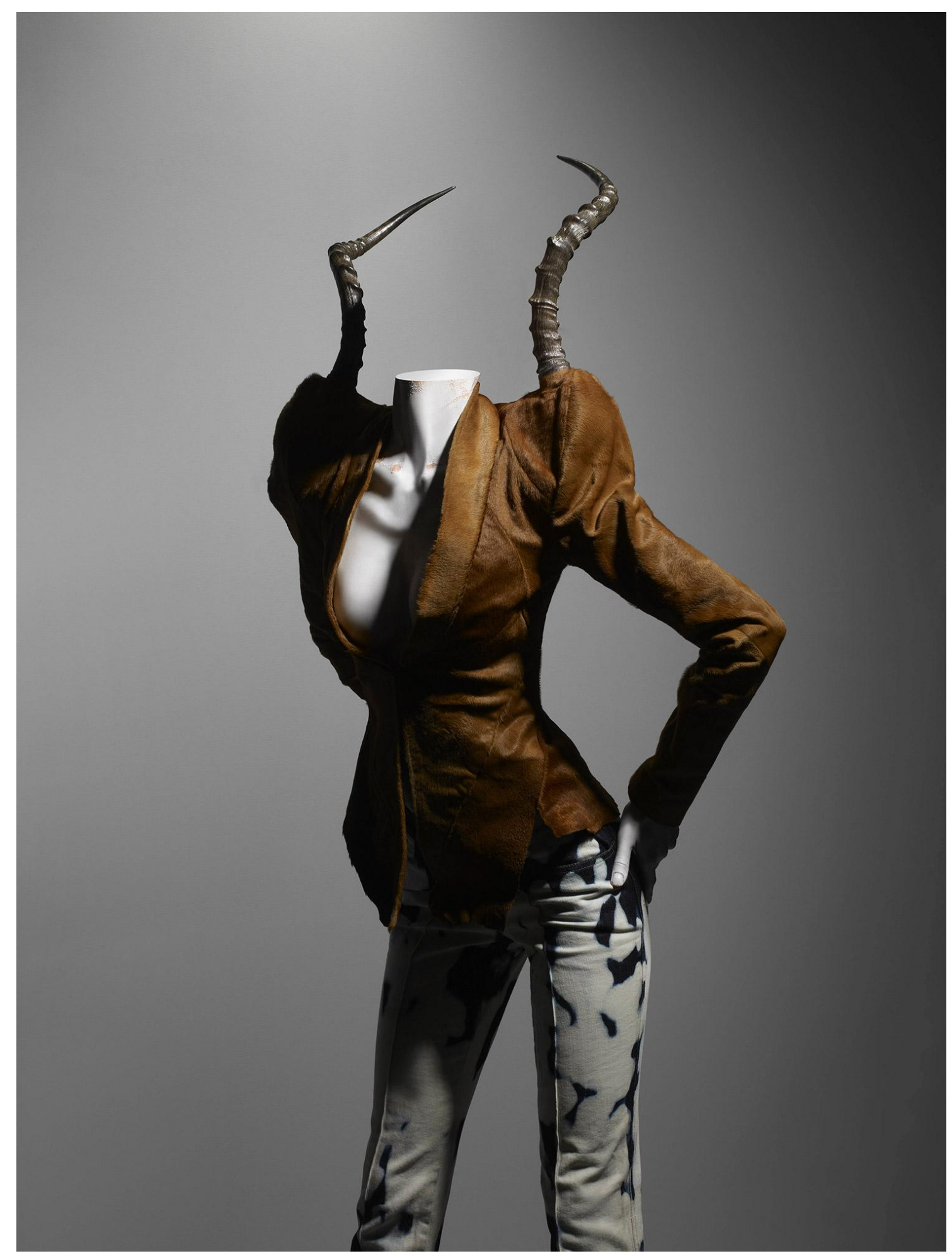

Placa 29a. Alexander McQueen. Colección It's a Jungle Out There. 


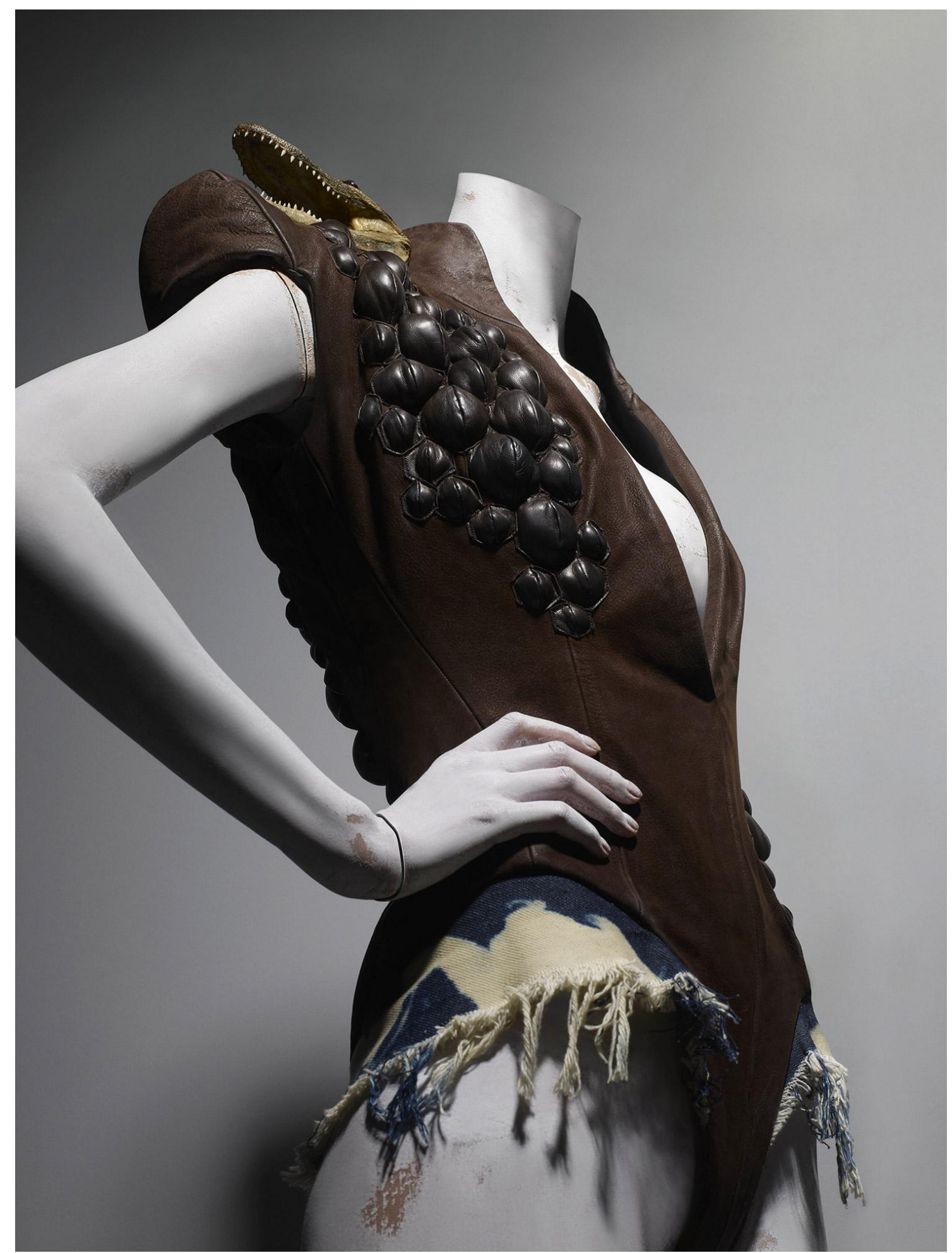

Placa 29b. Alexander McQueen. Colección It's a Jungle Out There. 


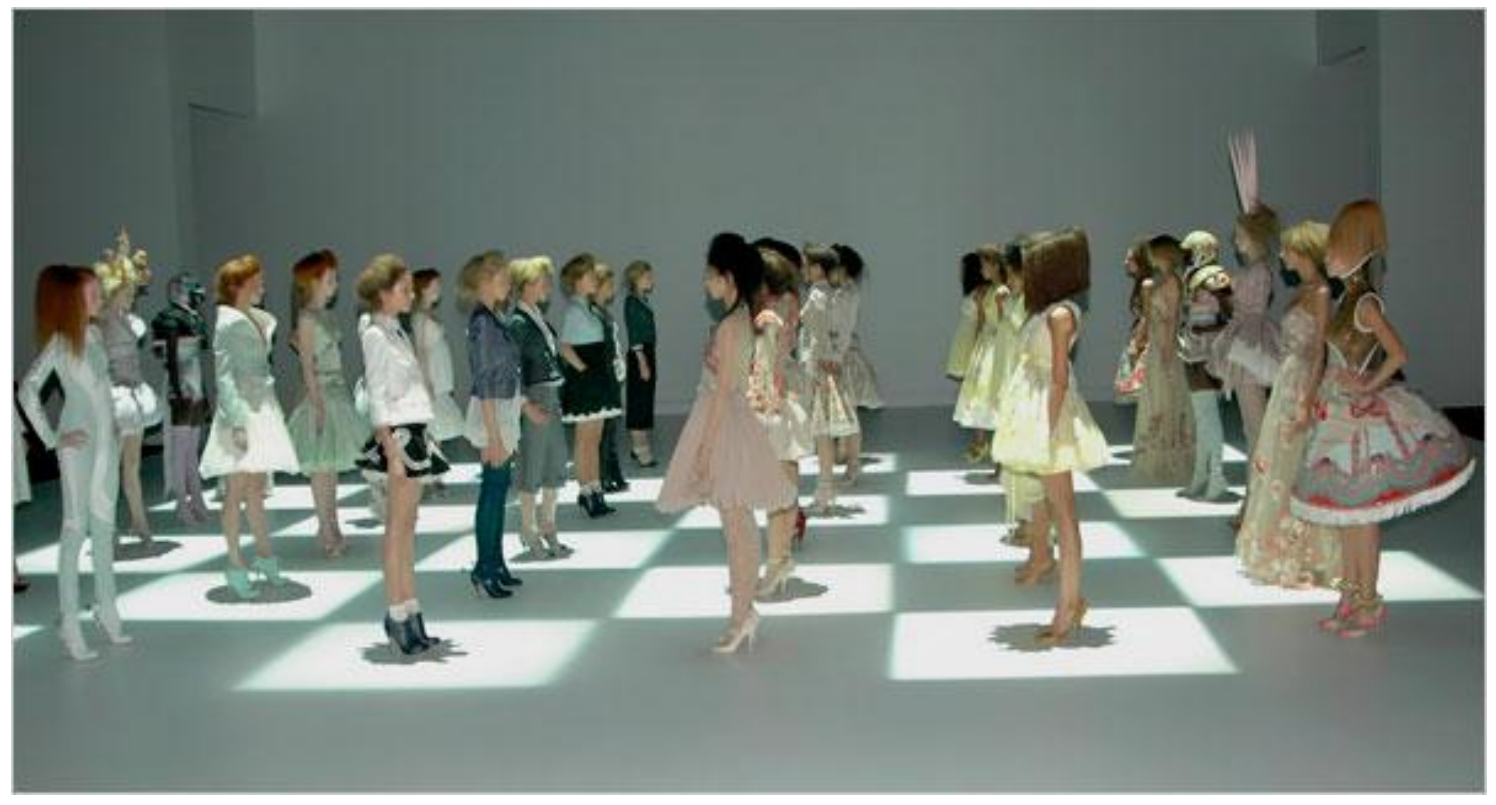

Placa 30. Alexander McQueen. Colección It's Only a Game. 



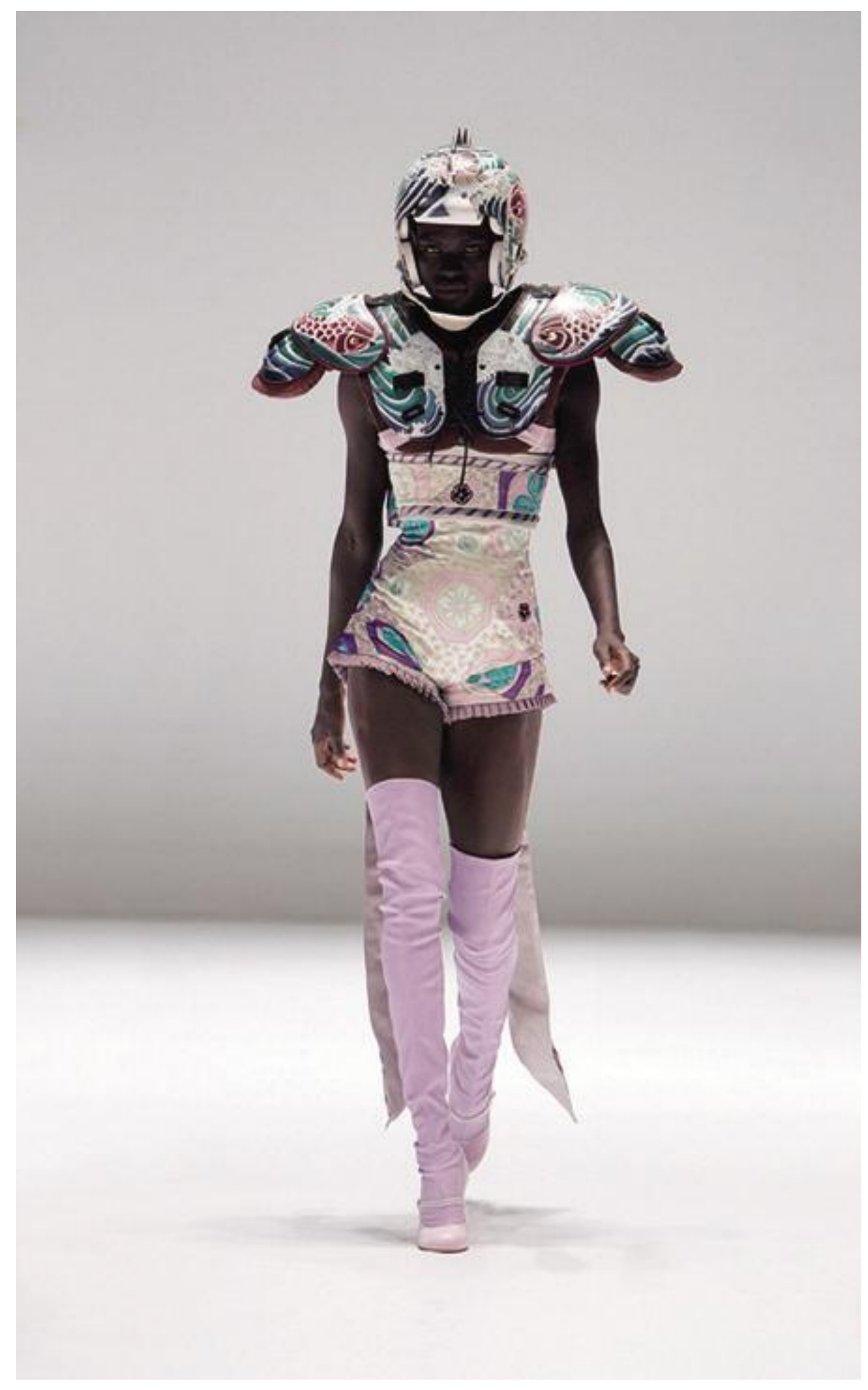

Placa 30b. Alexander McQueen. Colección It's Only a Game. 


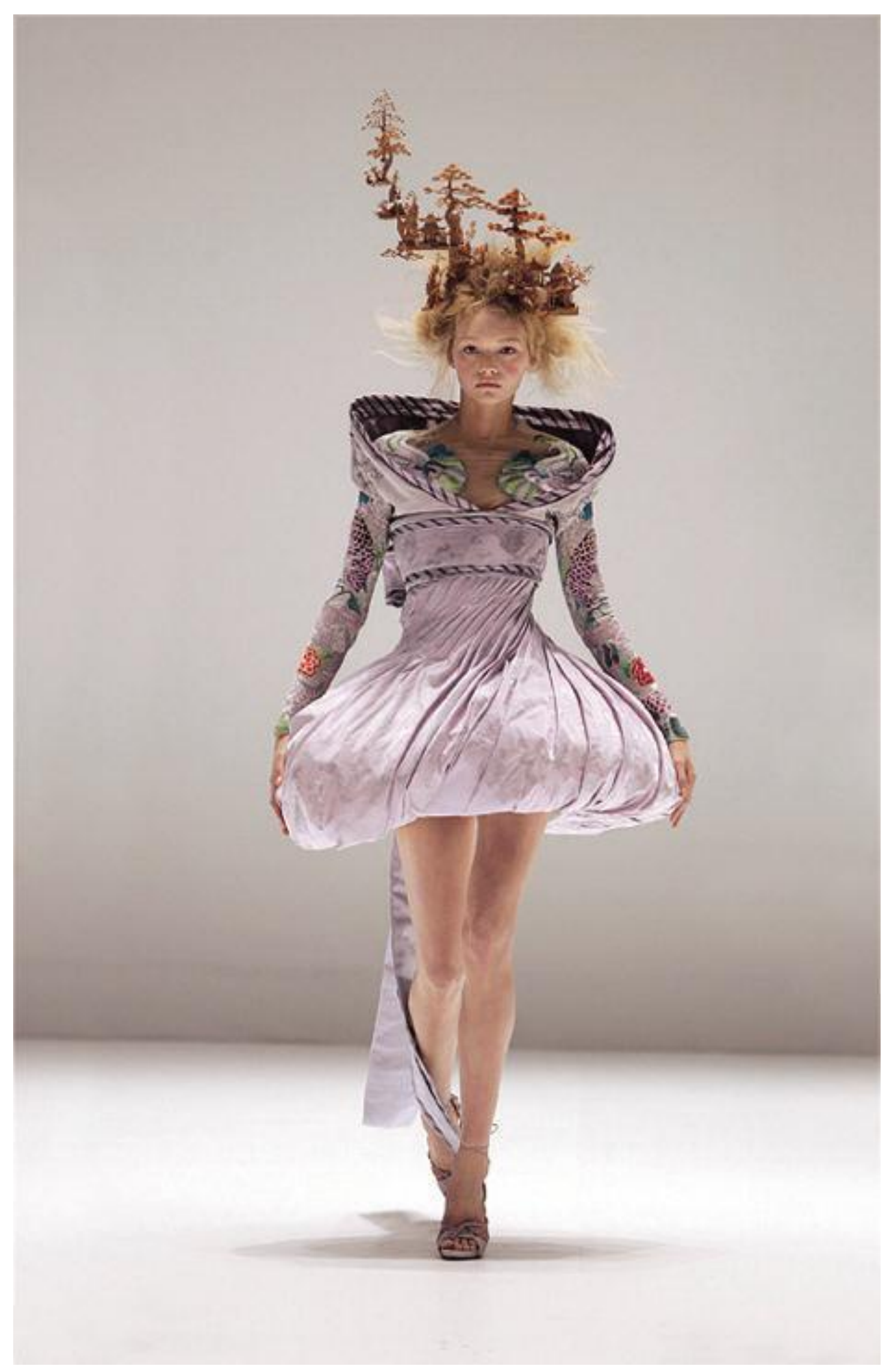

Placa 30c. Alexander McQueen. Colección It's Only a Game. 

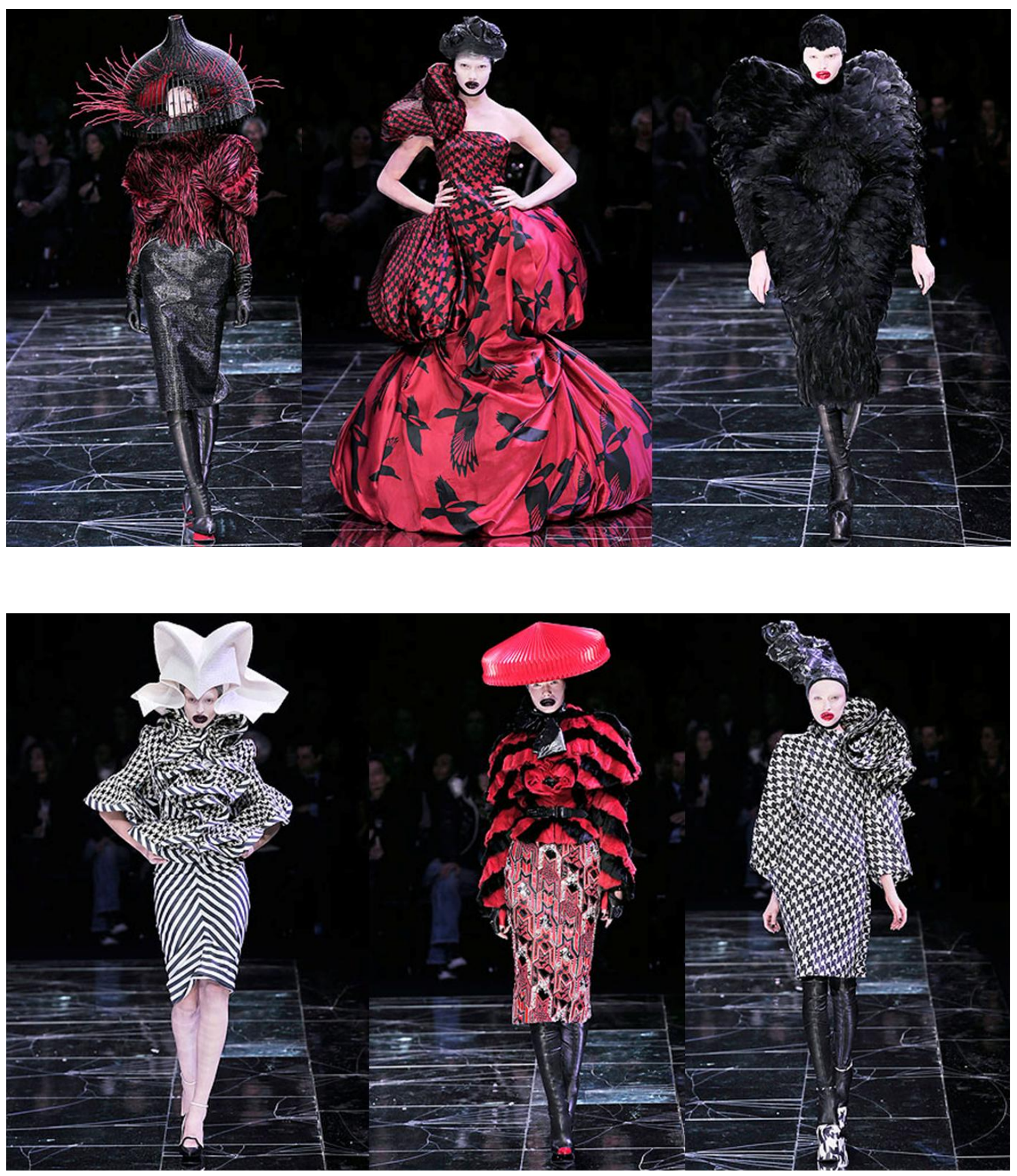

Placas 31 y 31a. Alexander McQueen. Colección The Horn of Plenty. 


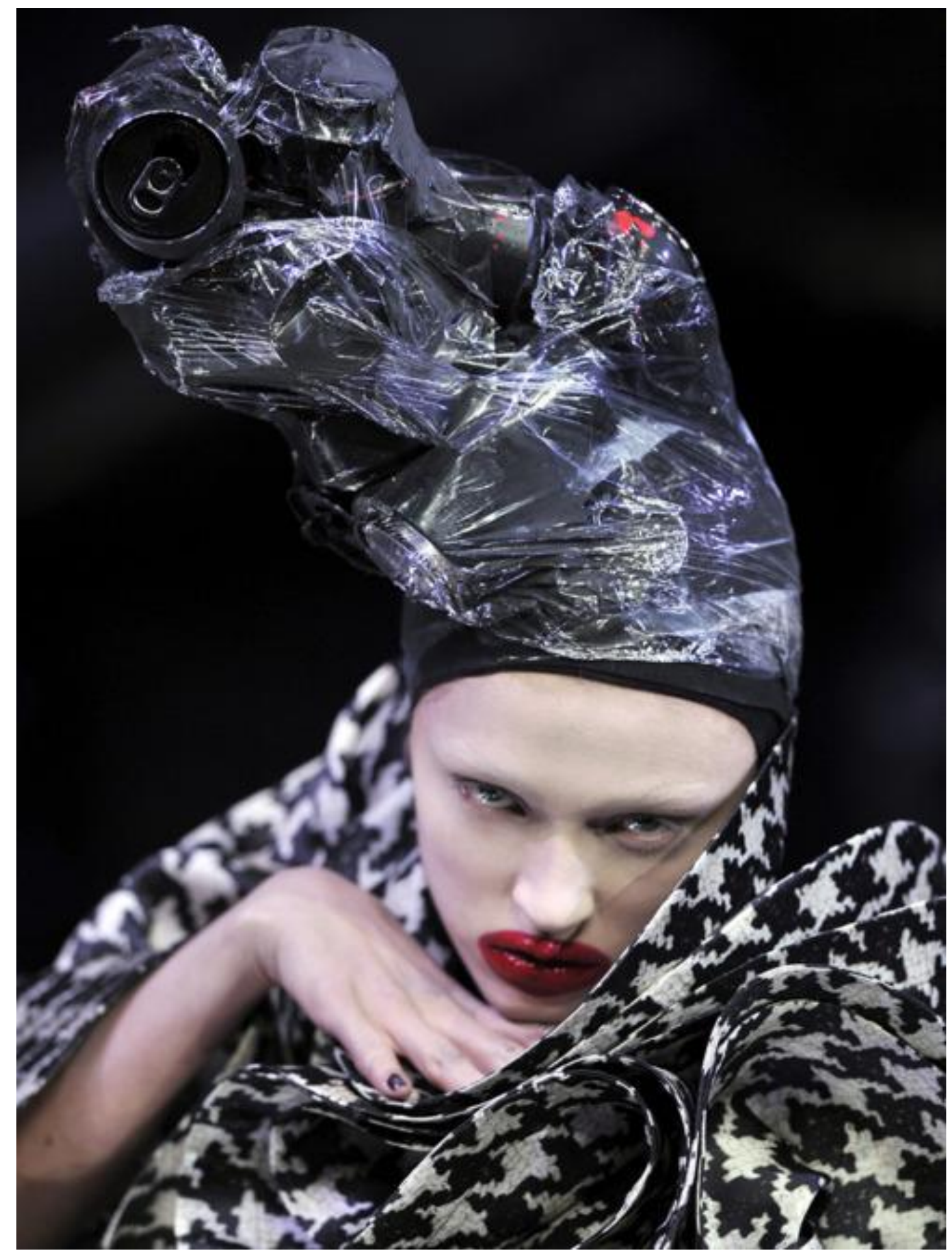

Placa 31b. Alexander McQueen. Colección The Horn of Plenty. 


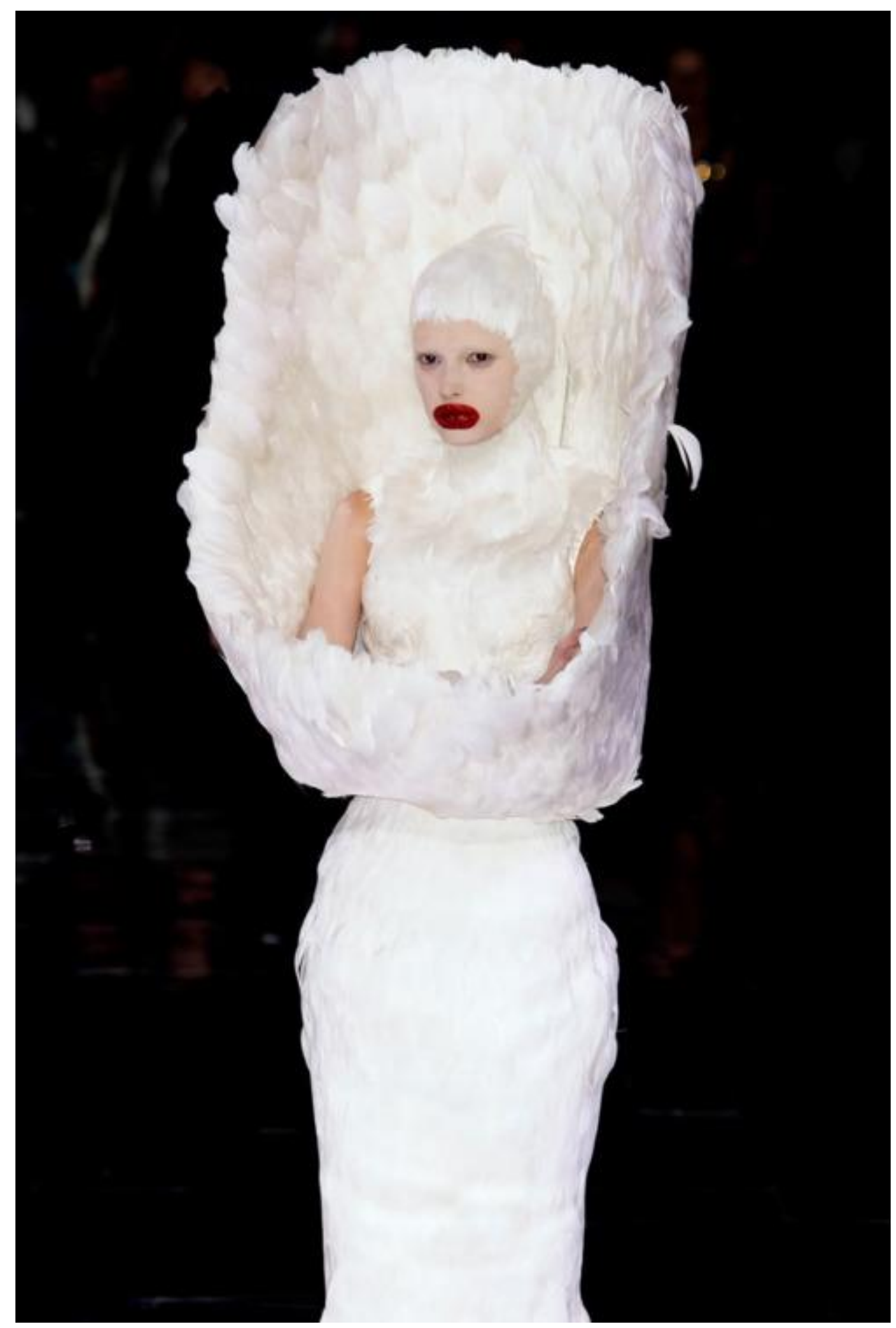

Placa 31c. Alexander McQueen. Colección The Horn of Plenty. 


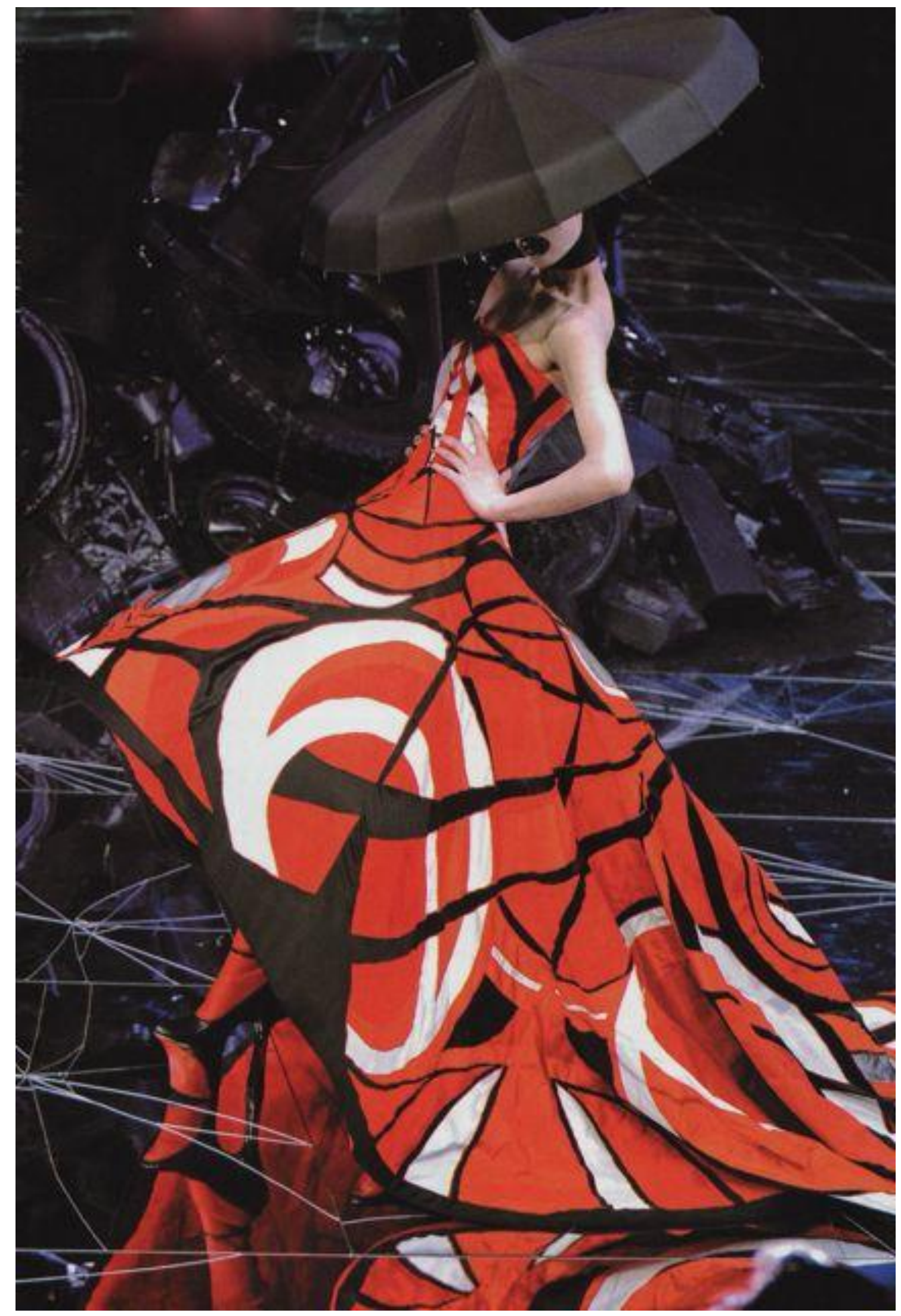

Placa 31d. Alexander McQueen. Colección The Horn of Plenty. 


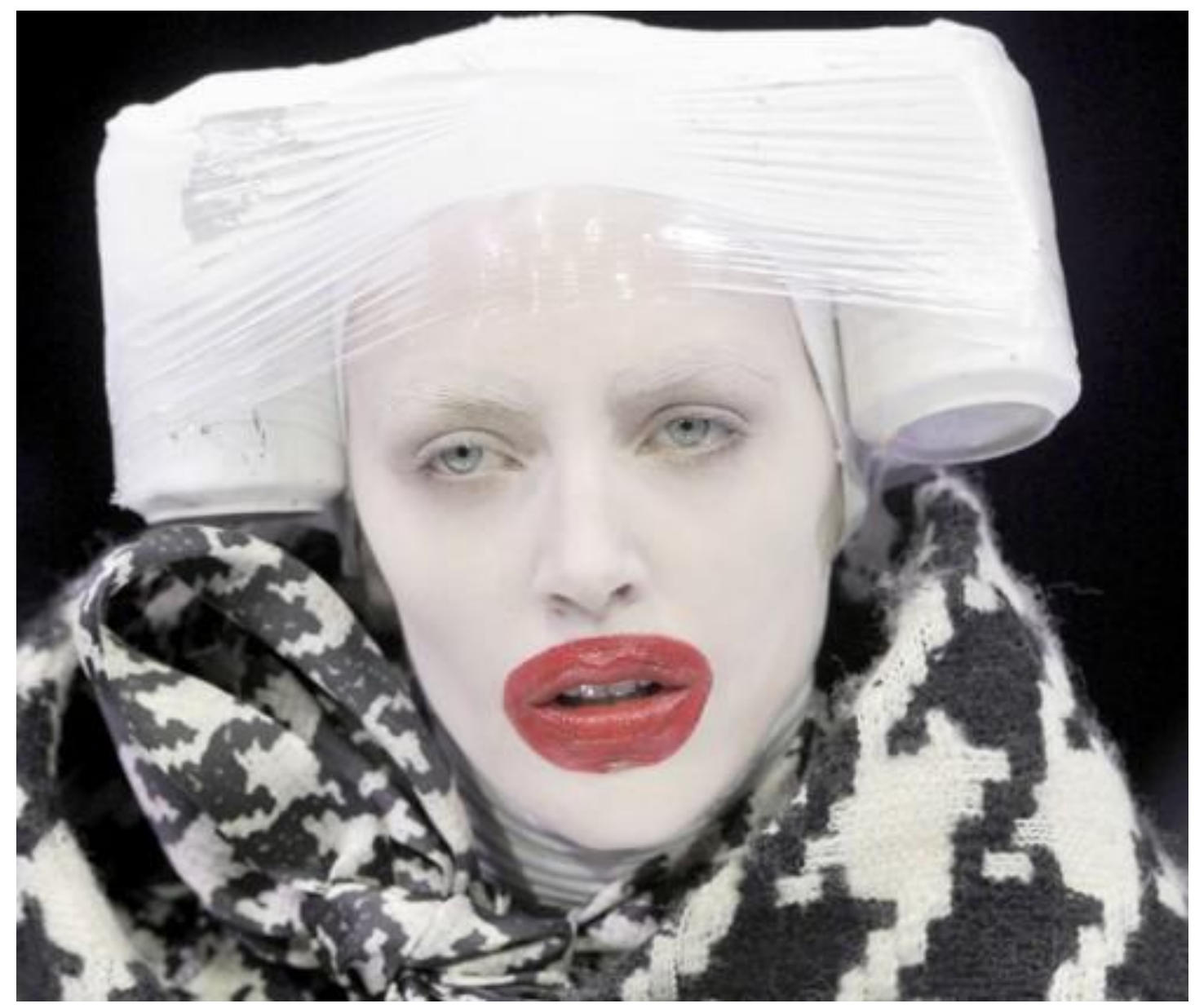

Placa 31e. Alexander McQueen. Colección The Horn of Plenty. 


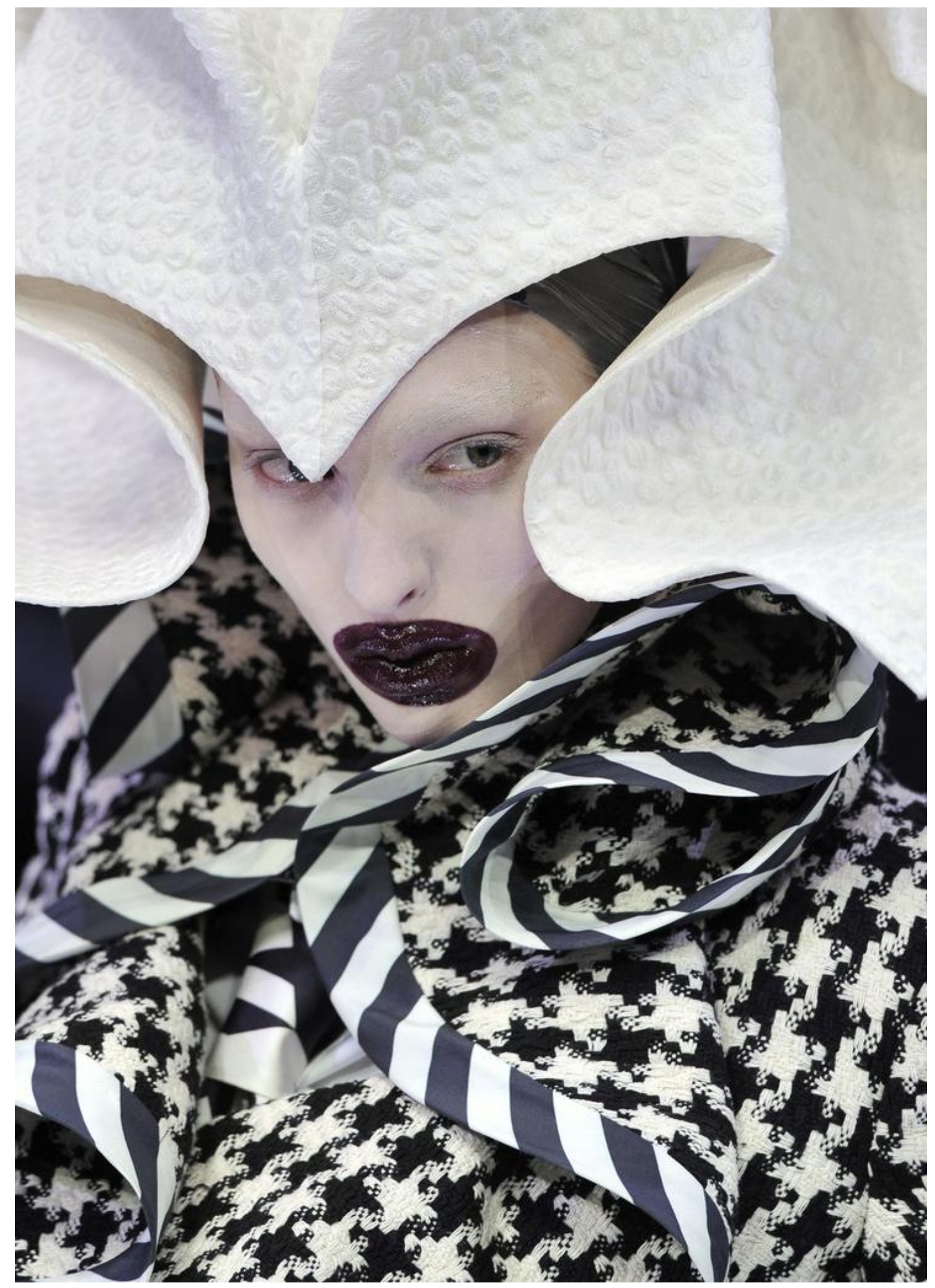

Placa 31f. Alexander McQueen. Colección The Horn of Plenty. 


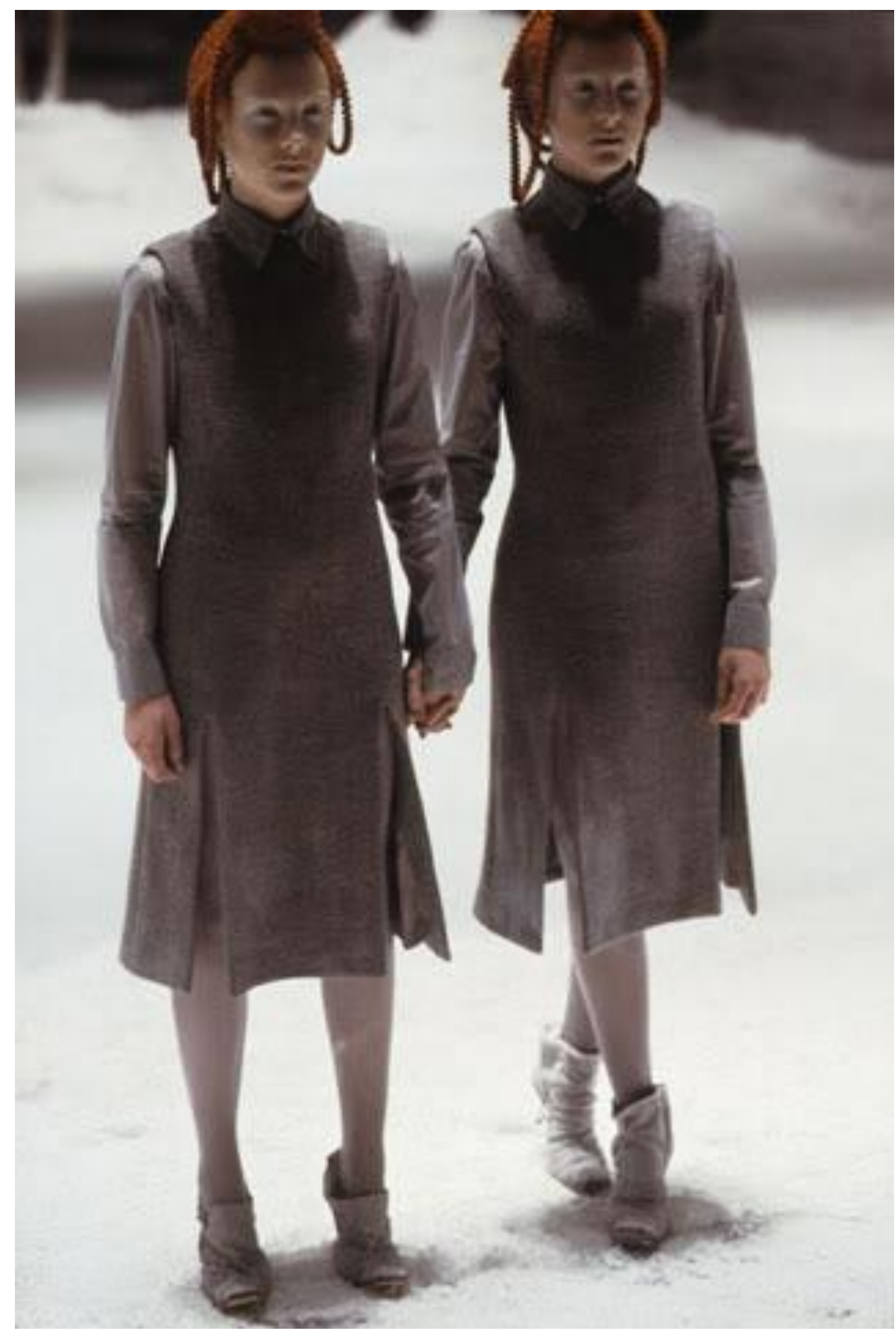

Placa 32. Alexander McQueen. Colección The Overlook. 


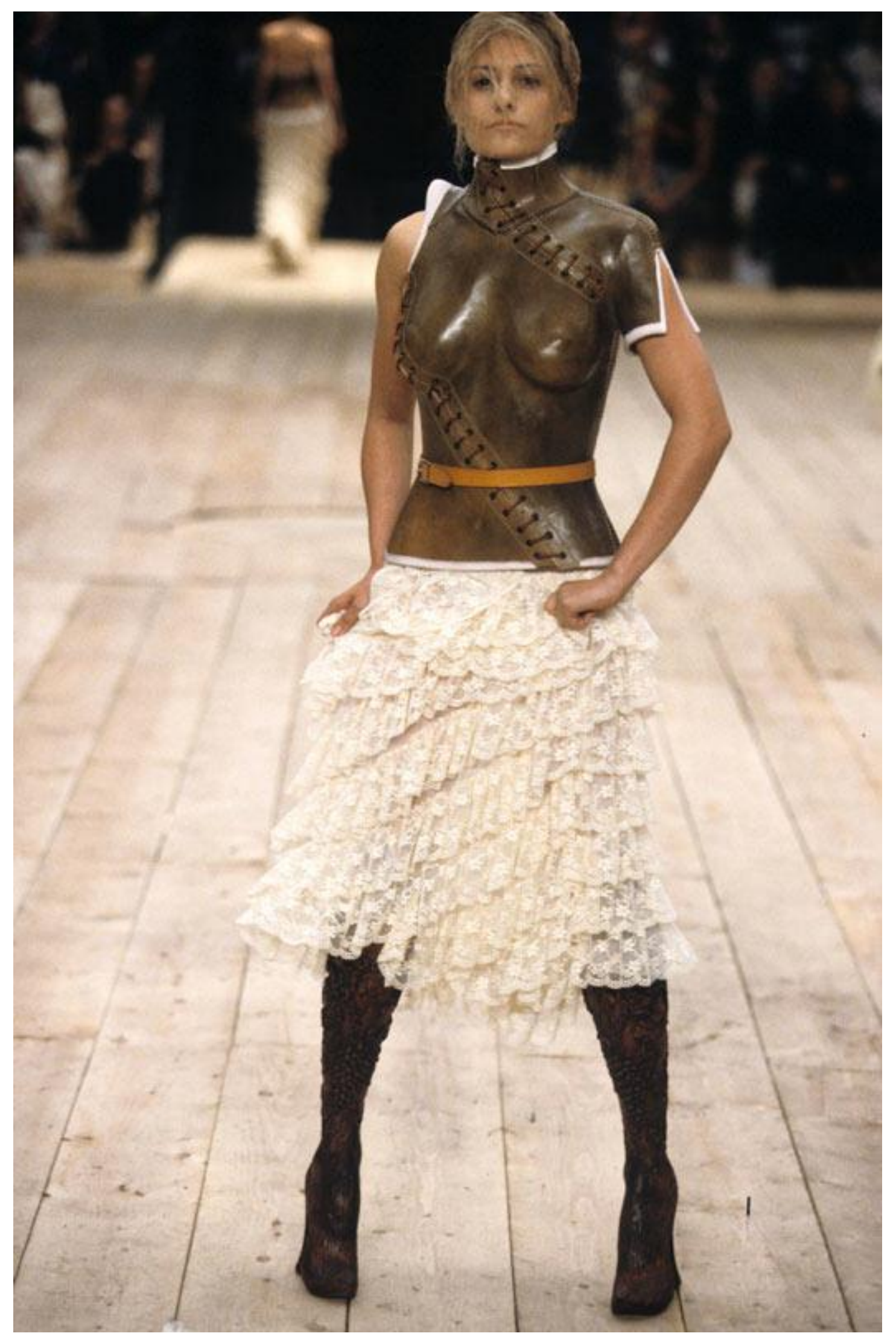

Placa 33. Alexander McQueen. Colección primavera/verano 1999. 


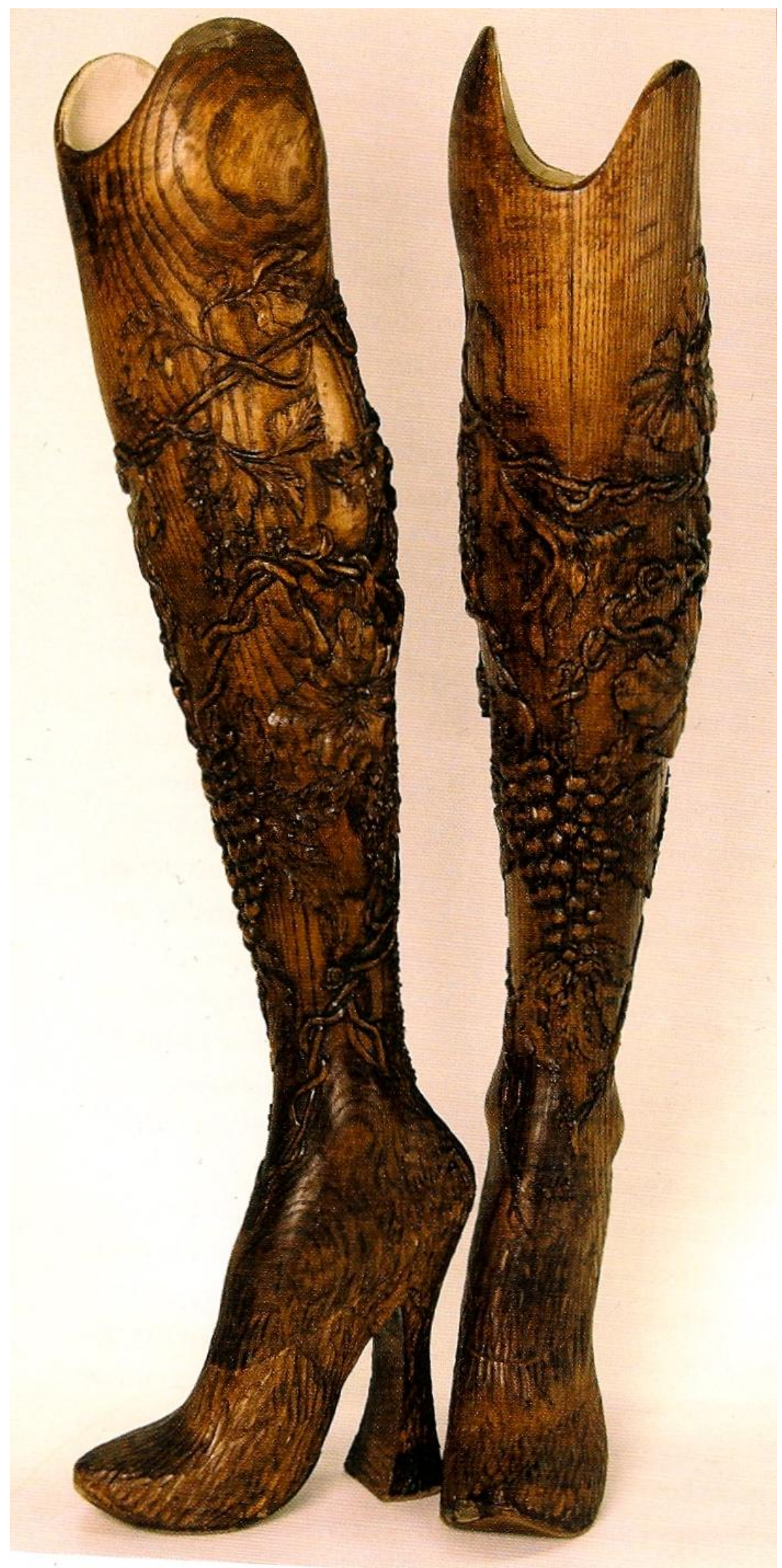

Placa 33a. Alexander McQueen. Colección primavera/verano 1999. Piernas labradas en madera. Detalle. 

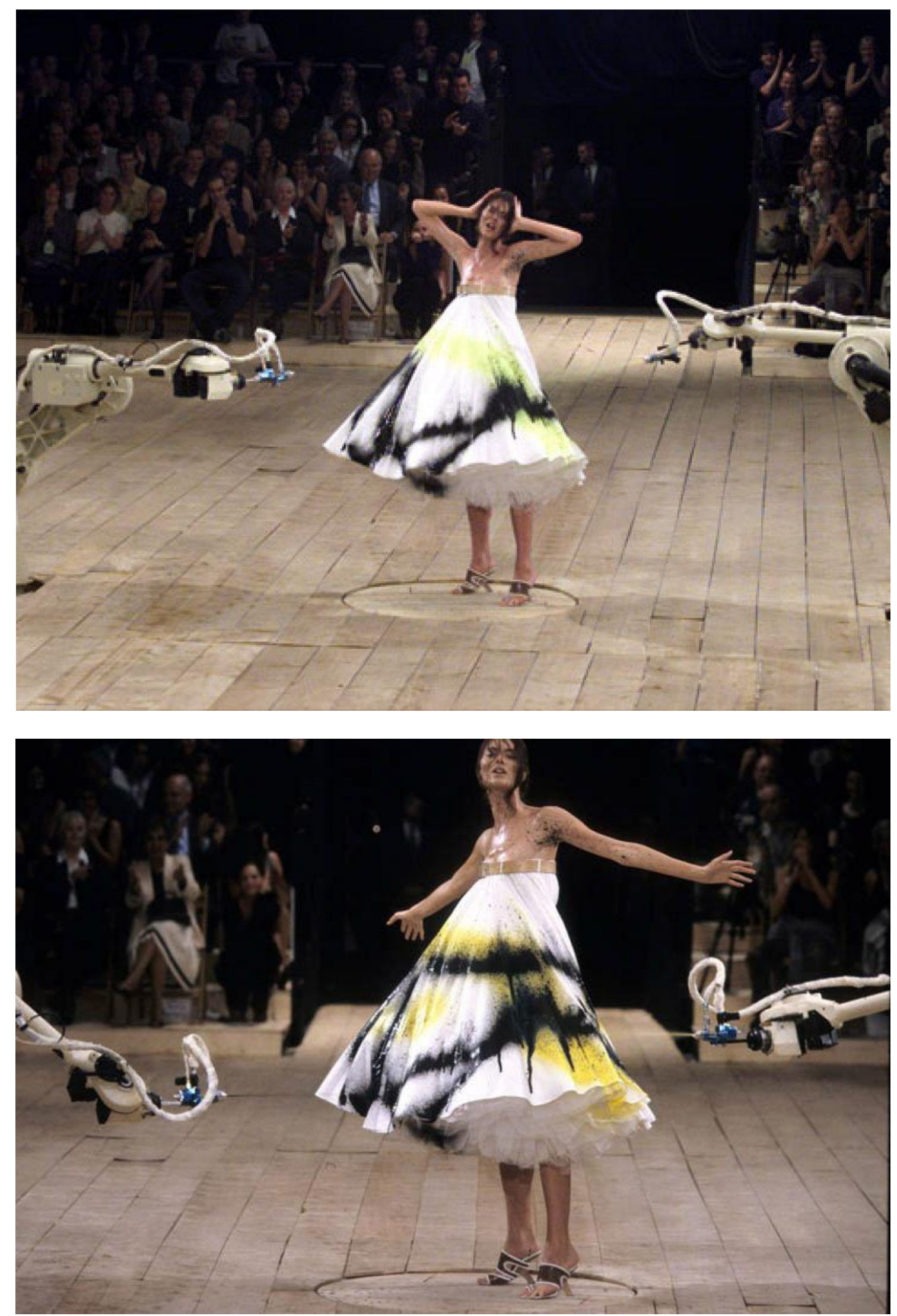

Placas 34 y 34. Alexander McQueen. Colección primavera/verano 1999. 


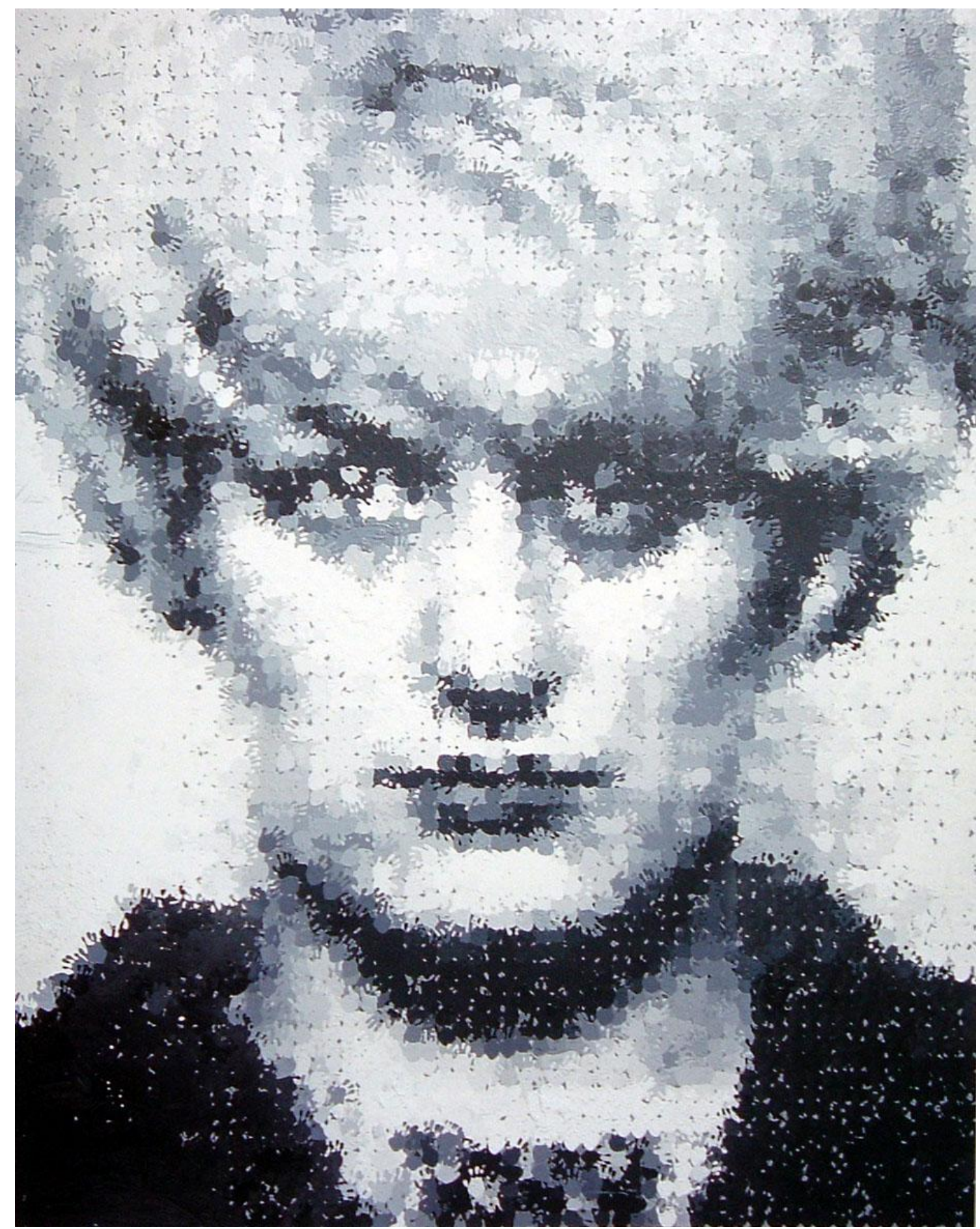

Placa 35. Marcus Harvey. Myra Hindley. 1995. 


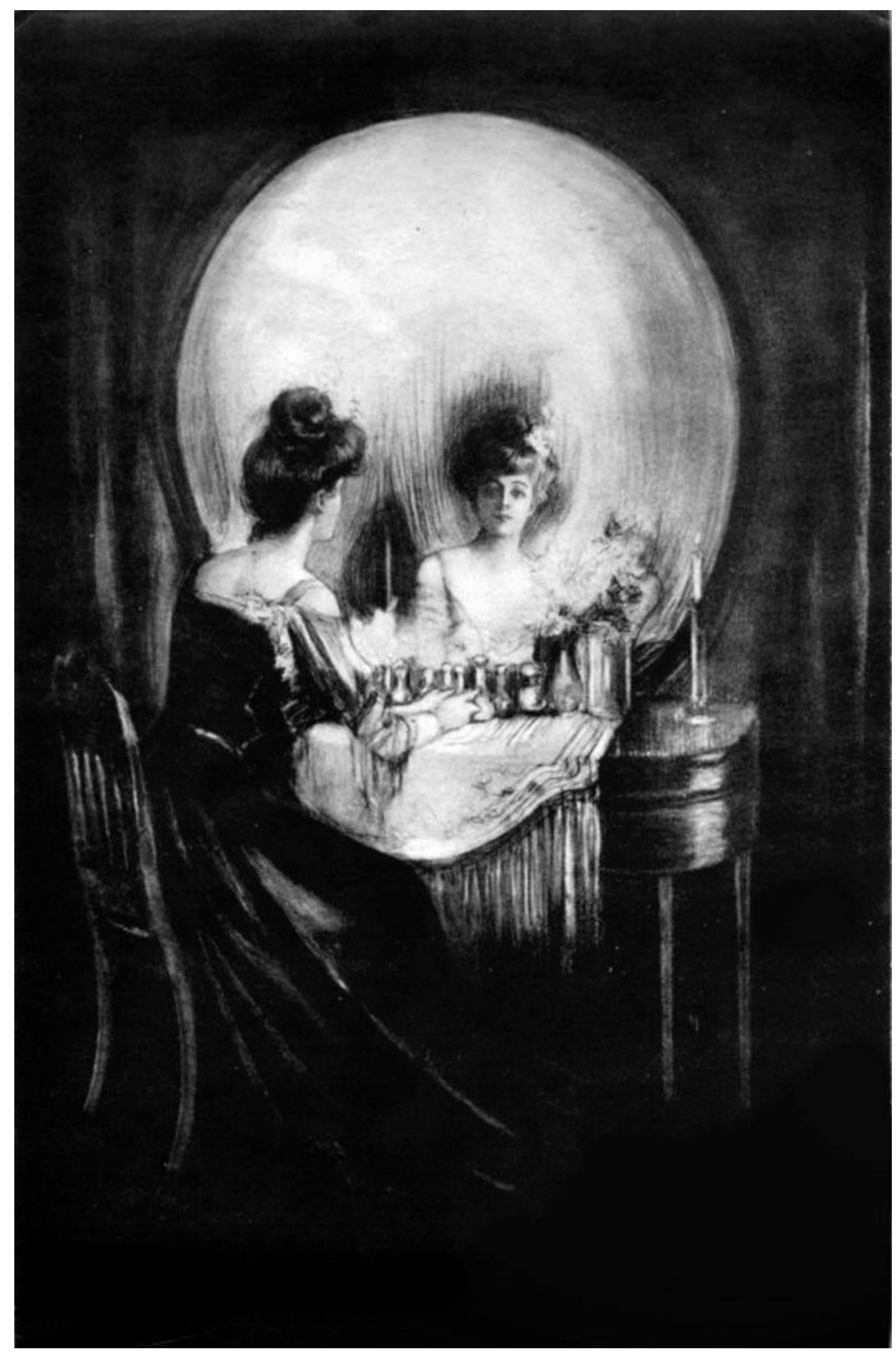

Placa 36. Charles Dana Gibson. All Is Vanity. 


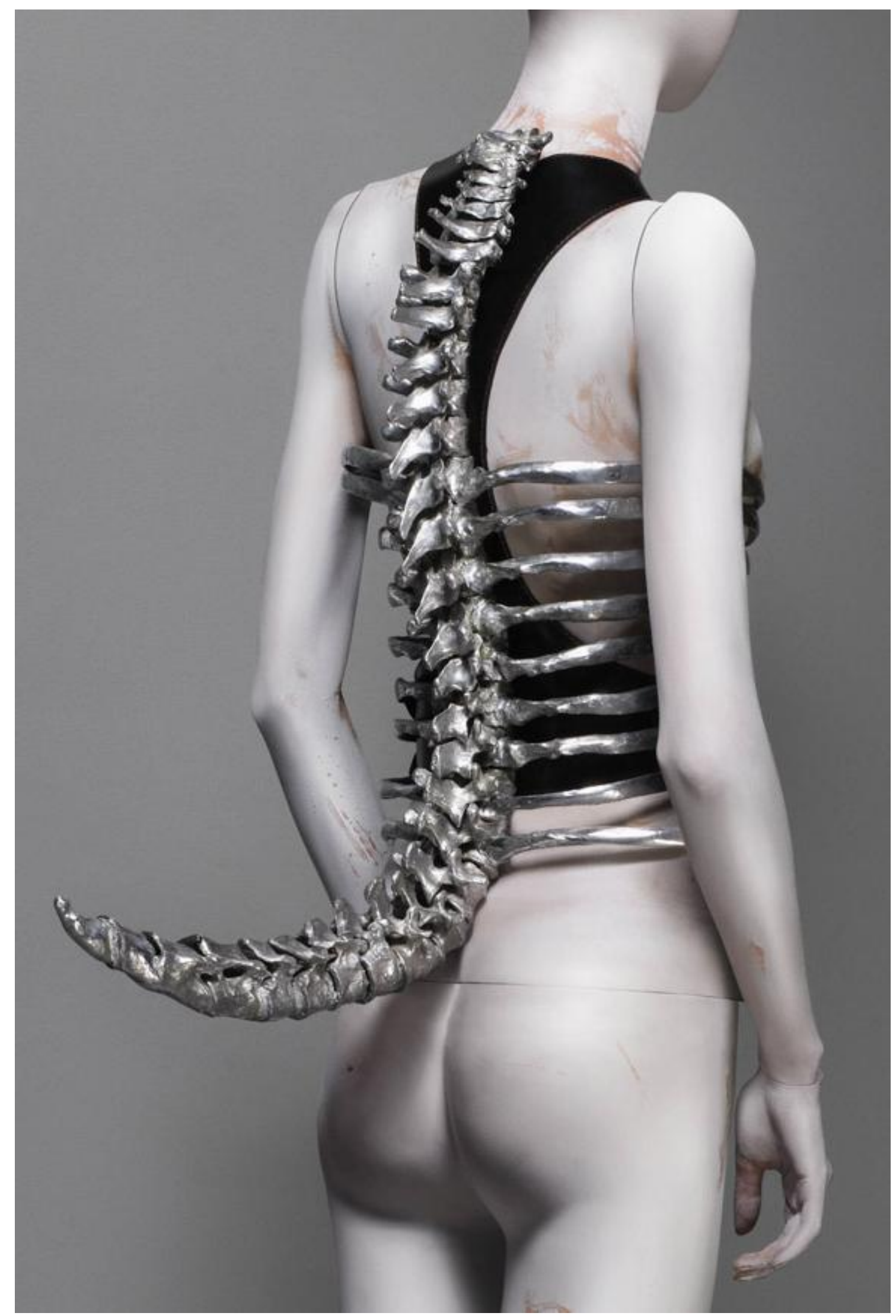

Placa 37. Alexander McQueen. Colección primavera/verano 1998. 


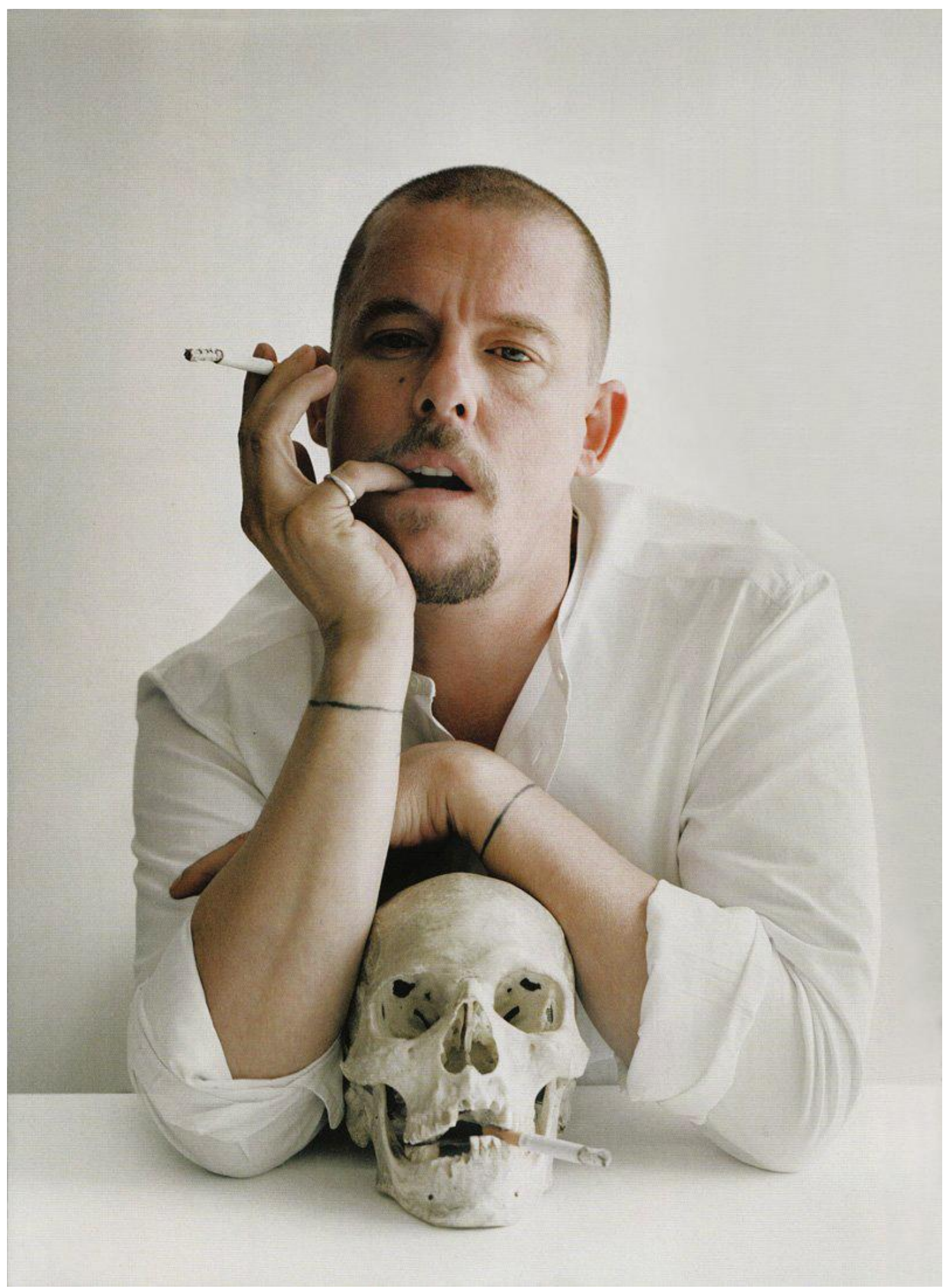

Placa 38. Alexander McQueen. 


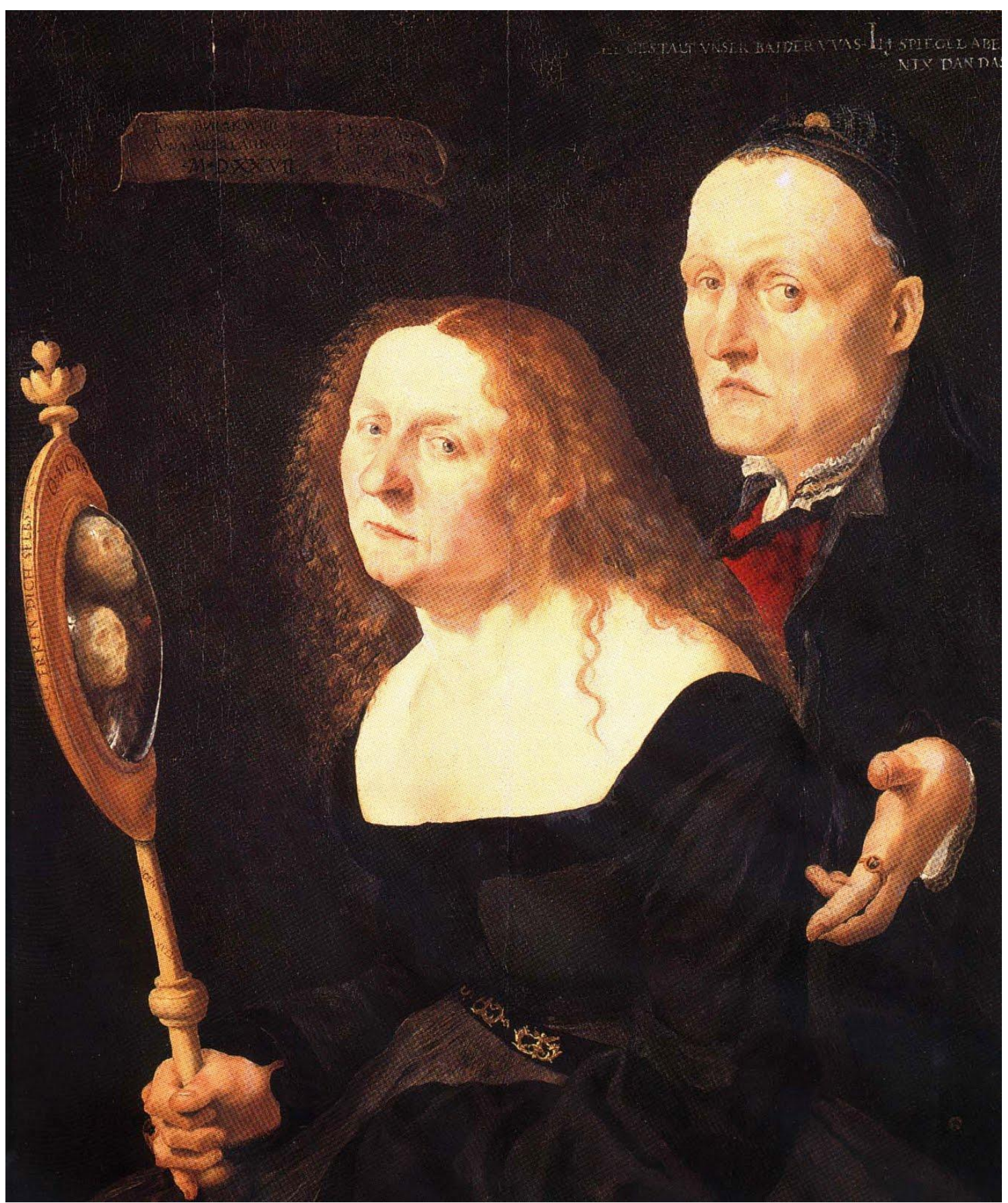

Placa 39. Lucas Furtenegal. Retrato del pintor Hans Burkgmair y su esposa Ana, 1529. 


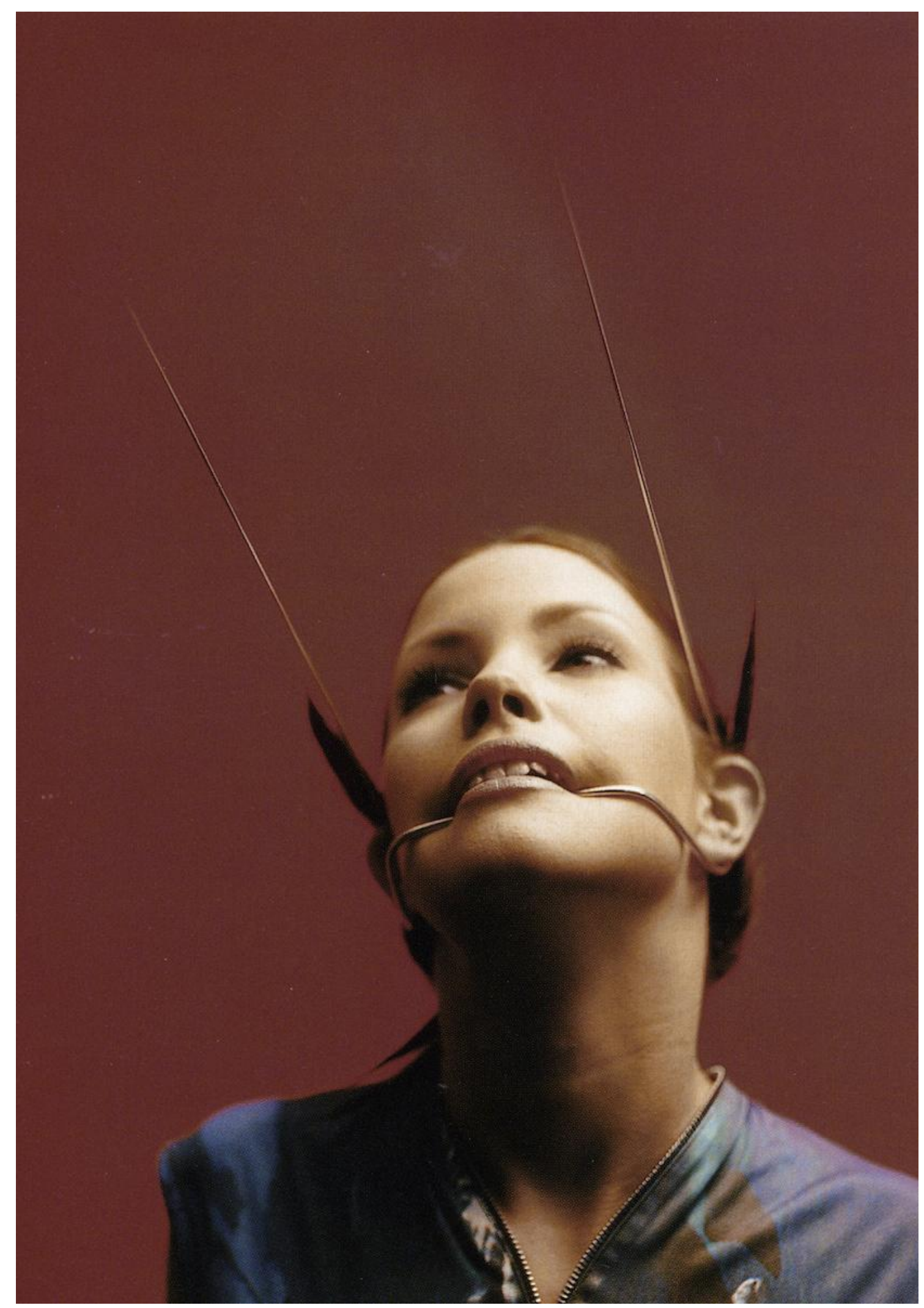

Placa 40. Alexander McQueen. Accesorio. 


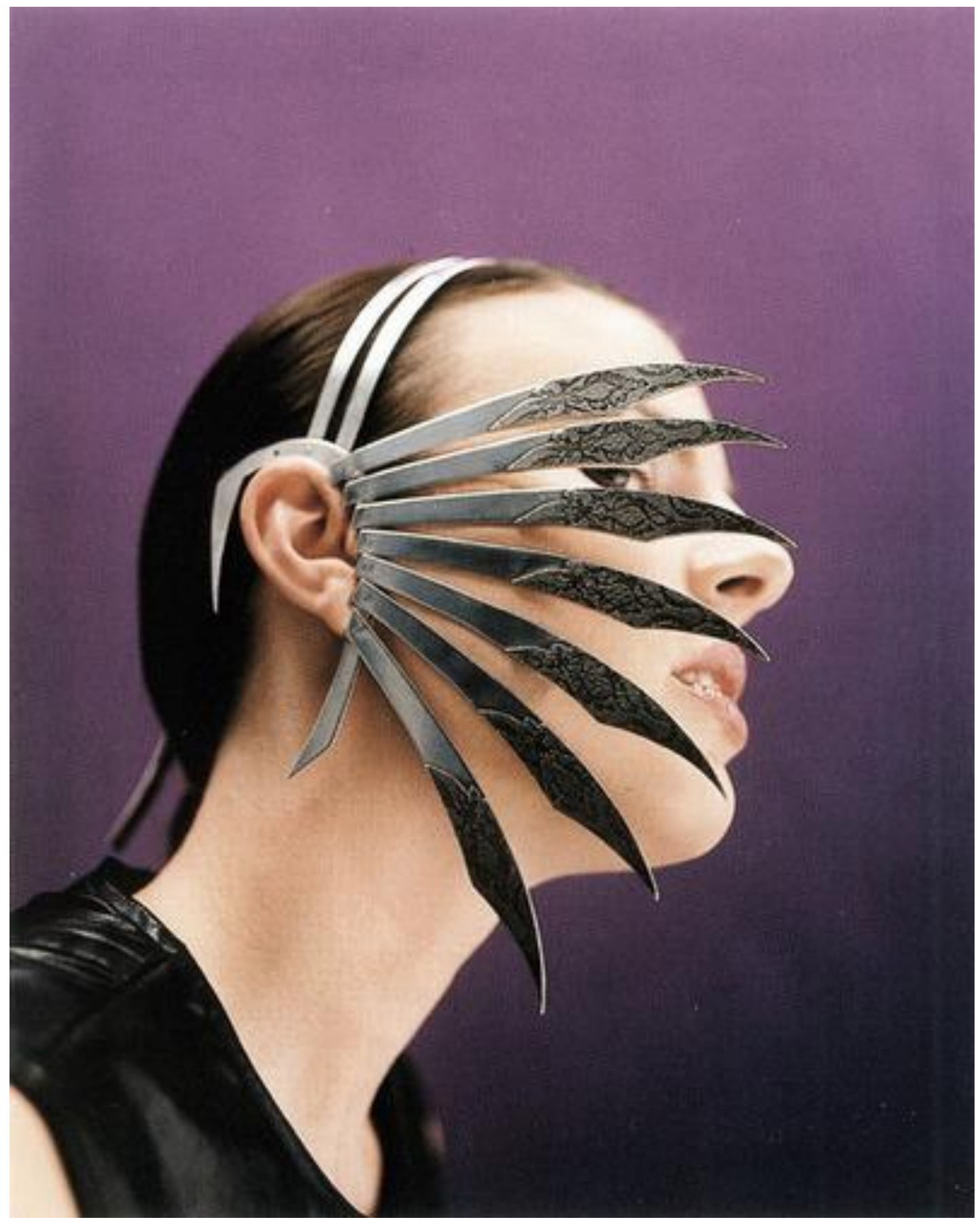

Placa 41. Alexander McQueen. Accesorio. 


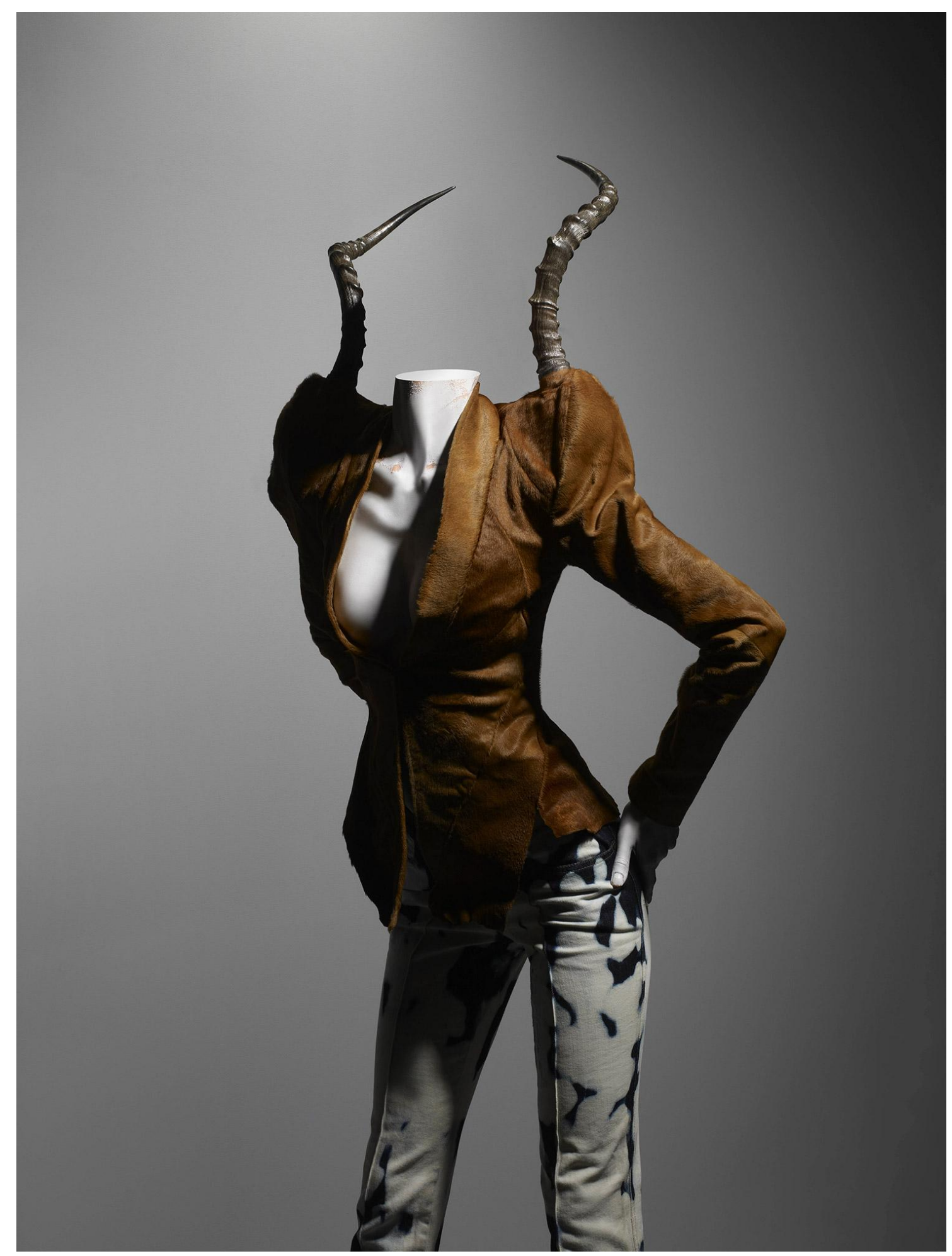

Placa 42. Alexander McQueen. Colección It's a Jungle Out There. 


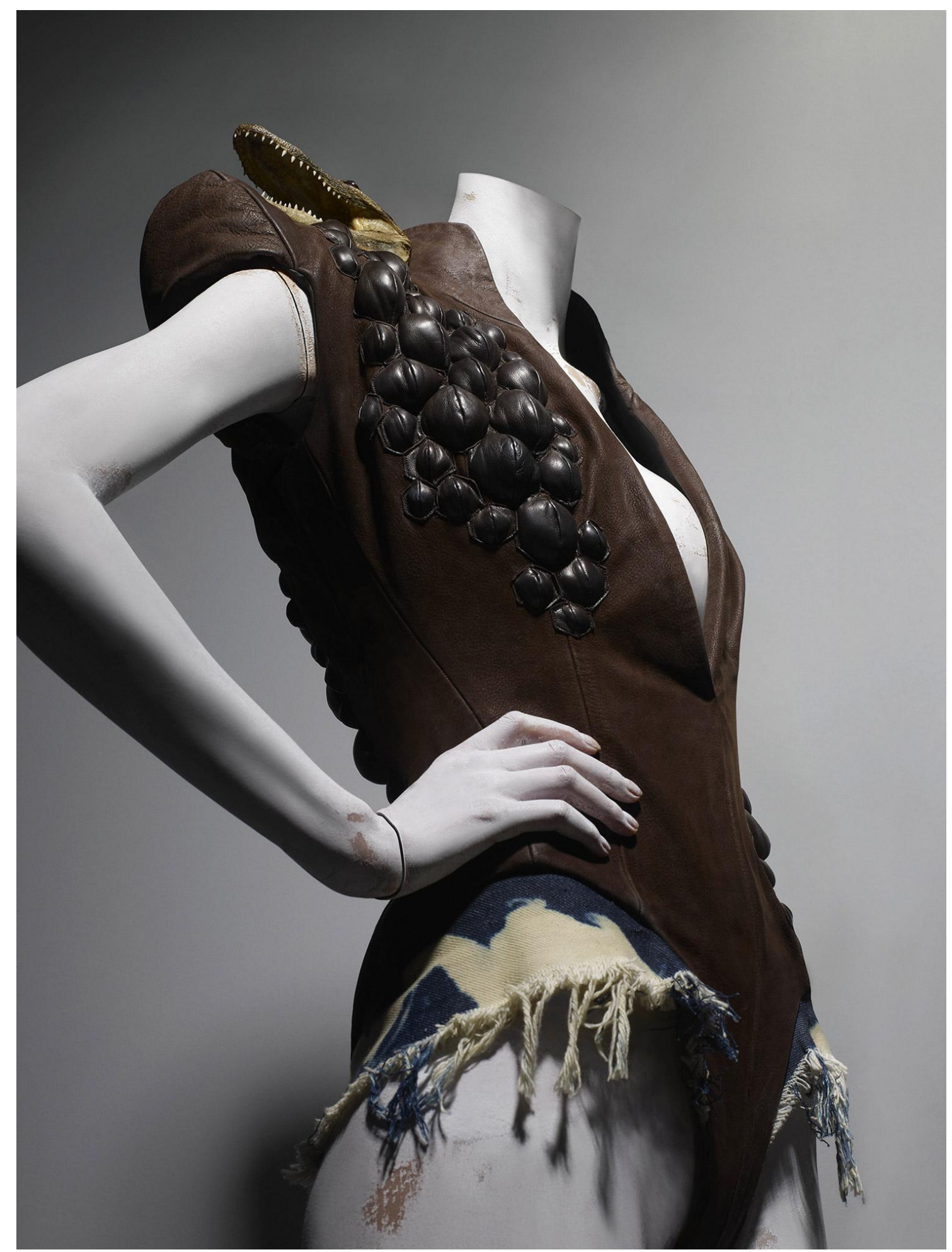

Placa 42a. Alexander McQueen. Colección It's a Jungle Out There. 


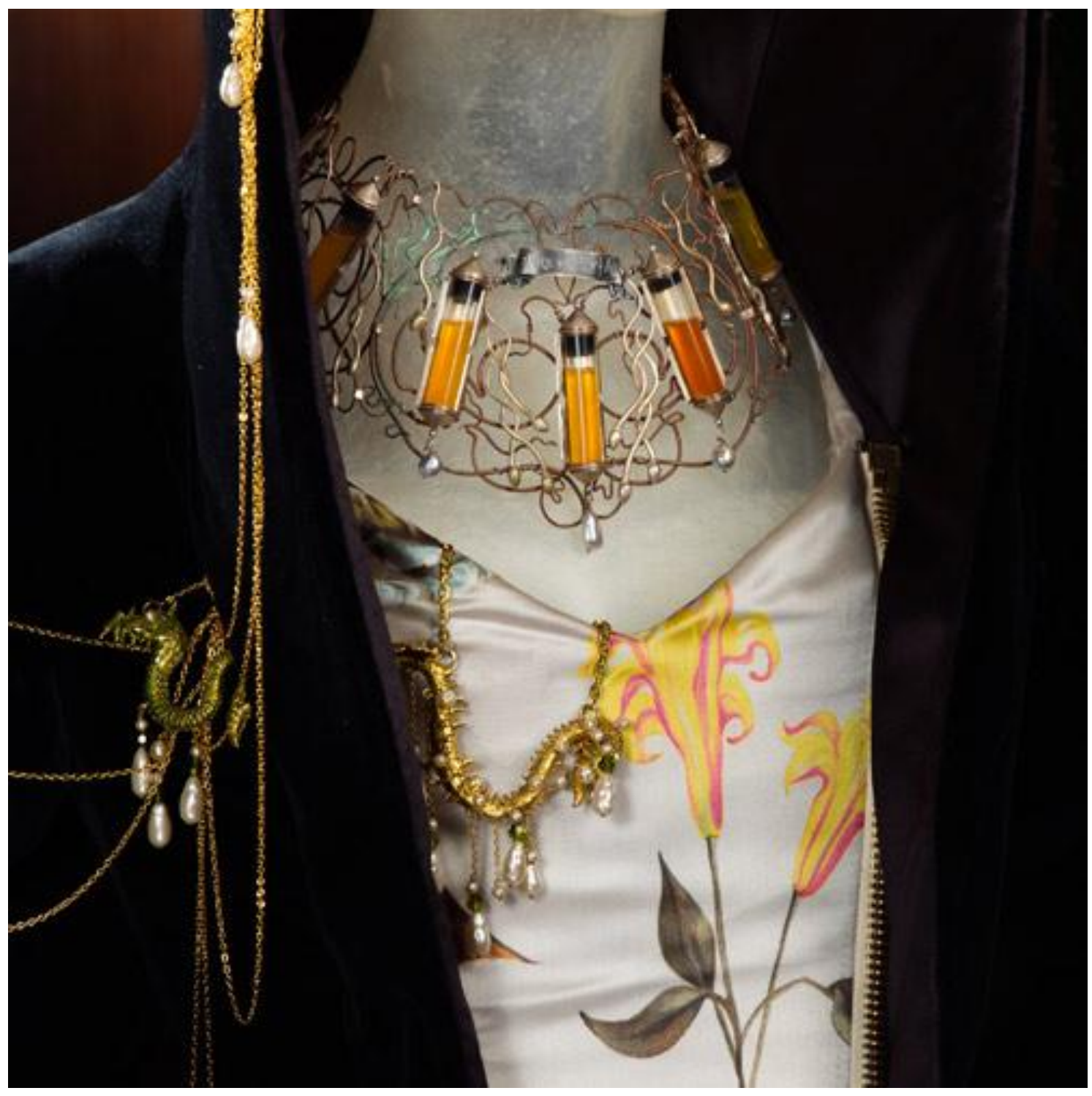

Placa 43. Alexander McQueen. Accesorio. 


\section{Trabajos citados y/o consultados}

Abraham, Nicholas y Torok, Maria. The Shell and The Kernel. Vol.1. University of Chicago Press, Chicago y Londres, 1994.

Abraham, Nicholas. Torok, Maria. La corteza y el núcleo. Amorrortu Editores. España, 2005.

Adorno, Th.W. Teoría estética. Ediciones Akal. Madrid, 2004.

Adorno. Th.W. Adorno. Monografías musicales. Ensayo sobre Wagner Mahler. Ediciones Akal. Madrid, 2008.

Alticks, Richard D. The Shows of London. Cambridge, 1978.

Ariès, Philippe. Morir en Occidente. Desde la edad Media hasta nuestros días. Adriana Hidalgo Editora. Buenos Aires, 2012.

Arnold, Rebecca. Fashion, Desire and Anxiety: Image and Morality in the Twentieth Century. I.B. Tauris, Londres y Nueva York, 2001.

Arthur Schopenhauer. El mundo como voluntad y representación. FCE. México, 1975.

Bahba Komi k. Articulating the Archaic. Notes on Colonial Nonesense. Routledge, Nueva York. 1990.

Bahba, Homi K. The Ambivalence of Colonial Discourse. Routledge, Nueva York. 1990.

Baker, Sheridan. Henry Fielding's the Female Husband: Fact and Fiction. Vol. 74, No.3 (Junio, 1959), Pp. 213-224. http://www.jstor.org/stable/460583

Ballard, J.G. Diary. New Statesmen. Dic. 1999-Enero 2000.

Bancroft, Alison. Fashion and Psychoanalysis. Styling the Self. I. B. Tauris, Londres y Nueva York. 2012.

Barthes, Roland. El sistema de la moda. Gustavo Gili. Barcelona, 1971.

Barthes, Roland. La cámara lúcida. Notas sobre la fotografía. Ed. Paidós. México, 1990.

Barthes, Roland. Sistema de la moda. Ed. Gustavo Gilí. Barcelona, 1989.

Bataille, Georges, La conjuración sagrada: Ensayos 1929-1939, Buenos Aires, Adriana Hidalgo, 2003.

Baudelaire, Charles. El pintor de la vida moderna. Librería Yerba, Murcia, 1995.

Baudrillard, Jean. Las estrategias fatales. Ed. Anagrama. Barcelona, 2000.

Baudrillard, Jean. Crítica a la economía política del signo. Siglo XXI. México, 1989.

Baudrillard, Jean. El intercambio simbólico y la muerte. Monte Ávila editores. Caracas, 1980. 
Baudrillard, Jean. El sistema de los objetos. Siglo XXI. México, 1987.

Baudrillard, Jean. La sociedad de consumo. Plaza \& Janés. Barcelona, 1989.

Bayer, R. Historia de la estética. FCE. México, 1987.

Bejamin, Walter. El libro de los pasajes. Ediciones Akal. Madrid, 2005.

Benjamin, Walter. A Berlin Chronicle, en One Way Street and Other Writtings. Ed. Verso, Londres, 1985.

Benjamin, Walter. Charles Baudelaire, A Lyric Poet in the Era of High Capitalism. Ed. Verso. New York, 1973.

Benjamin, Walter. El origen del drama barroco alemán. Ed. Taurus. Madrid, 1990.

Benjamin, Walter. Escritos autobiográficos. Alianza Editorial. Madrid, 1996.

Benjamin, Walter. La obra de arte en la época de su reproductibilidad técnica. Ed. Taurus. Madrid, 1973.

Benjamin, Walter. Sobre el concepto de la historia. Ed. Taurus. Madrid, 1973.

Benjamin, Walter. Tesis de filosofía de la historia. Ed. Angelus Novus. Barcelona, 1971.

Bergler, Edmund. Fashion and the unconscious. B. Brunner. Nueva York, 1953.

Berman, Marshall. All That is Solid Melts into Air: The Experience of Modernity. Ed. Verso. Londres, 1983.

Berman, Marshall. Todo lo sólido se desvanece en el aire. La experiencia de la modernidad. Siglo XXI Editores. Madrid, 1988.

Bernstein, Susan. It walks. The Ambulatory Uncanny. Moderno Language Notes No.118. 2003.

Bleuler, Eugen . Afectividad, sugestibilidad, paranoia. Fundación Española de Psiquiatría y Salud Mental. Editorial Triacastela, 2008.

Bloom, Harold. Agon. Towards a Theory of Revisionism. Oxford University Press. Oxford, 1982.

Bloom, Harold. Freud and the Poetic Sublime. A Catastrophe Theory of the Sublime. Prentice Hall, New York, 1981.

Bosanquet, Bernard. Historia de la estética. Vol. III. Ed. Nueva Visión, Buenos Aires, 1961.

Bourdieu, Pierre. "Alta cultura y alta costura" en Sociología y cultura. Ed. Grijalbo. México, 1990.

Bourdieu, Pierre. La distinción. Criterio y bases sociales del gusto. Ed. Taurus. Madrid, 1998. 
Brierre de Boismont. A History of Dreams, Visions, Apparitions, Ecstasy, and Somnambulism. Philadelphia, 1855. 1st American Translation of Des Hallucinations: ou, Histoire raisonnée des apparitions, des visions, des songes, de l'extase, des rêves, du magnétism et du somnambulisme, Paris, 1852.

Bryant, Dave. The Uncanny Valley. Why Are Monster-Movie Zombies So Horrifying and Talking Animals so Fascinating? www.arclight-net-nonfiction/uncanny-valley.html Buci-Glucksmann, Christine. Baroque Reason: The Aesthetics of Modernity. Ed. Sage. Londres, 1994.

Buck-Morss, Susan. The Dialectics of Seeing: Walter Benjamin and the Arcade Projects. MIT Press. Cambridge, 1991.

Bulwer-Lytton, Edward. A Strange Story and The Haunted and The Haunters. The Cassel Publishing Co. New York, 1986.

Bürger, Peter. Theory of the Avant-Garde. University of Minnesota Press. Minneapolis, 1984.

Burton, Robert. The Anatomy of Melancholy. Ed. Hollbrook Jackson. London and New York. 1964.

Castle, Terry. The Female Thermometer. Eighteenth-Century Culture and the Invention of the Uncanny. Oxford University Press. New York. 1995.

Castro, Edgardo. Diccionario Foucault. Temas, conceptos y autores. Siglo Veintiuno Editores. Buenos Aires, 2011.

Castro, Edgardo. El vocabulario de Michel Foucault. Un recorrido alfabético por sus temas, conceptos y autores. Siglo XXI Editores. Buenos Aires, 2011.

Cavallaro, Dani, Warwick, Alexandra. Fashioning the Frame. Boundaries, Dress and the Body. Berg Publishers, Nueva York, 1998.

Charke, Charlotte. A Narrative of the Life of Mrs. Charlotte Charke, Youngest Daughter of Colley Cibber, Written by Herself. Londres, Whittaker, Treacher, and Arnot, 2013.

Cixous, Hélène. Fiction and its phantoms. A Reading of Freud's Das Unheimlich. New Literary History 7, 1976.

Coates, Paul. The Double and The Other. Identity as Ideology in Post-Romantic Fiction. MacMillan, London. 1988.

Collingwood, Robin George. The Principles of Art. Clarendon Press. Oxford. 1963.

Cooper Dendy, Walter. The Philosophy of Mistery. London, 1841.

Craik, Laura. The Guardian. 19 de julio de 1999.

Crane, Diana. Fashion and Its Social Agendas: Class, Gender and Identity in Clothing. Chicago University Press, 2000.

Creed, Barbara. The Monstrous-Femenine. Film, Horror, and The Primal Uncanny. Melbourne University Press, 1993. 
Croci, Paula. Vitale, Alejandra. Los cuerpos dóciles. Hacia un tratado de la moda. Editorial La Marca. Buenos Aires, 2011.

Culler, Jonathan. On Deconstruction. Theory and Criticism After Structuralism. Routledge. London, 1993.

Dafoe, Daniel. Roxana: The Fortunate Mistress. Oxford University Press. Londres, 1974.

Danton, Robert. "Readers Respond to Rosseau: The Fabrication of Romantic Sensitivity." en The Great Cat Massacre and Other Episodes in French Cultural History. Ed. Random House, Nueva York, 1985.

Dany, Nobus. Freud versus Jentsch. Impreso en Psychoanalitic Perspective. 1993.

De Marly, Diana. Worth: Father of Haute Couture. Elm Tree Books. London, 1980.

De Azcárate, Patricio. Obras completas de Platón. Fedro. Tomo segundo, Madrid 1871, páginas 261-349; Timeo. Tomo sexto, Madrid 1871. páginas 147-264; La República. Madrid 1871, Tomos 7 y 8.

De Beauvoir, Simone. El segundo sexo. Ed. Siglo Veinte. México, 1986.

Debord, Guy. La sociedad del espectáculo. Observaciones filosóficas. Madrid, 1967.

Del Conde, Teresa. Freud y la estética. Una aproximación. Revista Anales del Instituto de Investigaciones Estéticas. Vol. XIII. No. 49. Año 1979.

Deleuze, Gilles, Guattari, Félix. ¿Qué es la filosofía? Anagrama, Barcelona, 1997.

Derrida, Jacques. Espectros de Marx. El estado de la deuda, el trabajo del duelo y la nueva Internacional. Editorial Trotta, Madrid,1998.

Derrida, Jaques. La diseminación. Editorial Fundamentos. Madrid, 1975.

Diderot. Sur les femmes. Édition Ornée. París, 1979.

Dijksra, Bram. Idols of Perversity: Fantasies of Femenine Evil in Fin-de-Siècle Culture. Oxford University Press. Oxford, 1986.

Discurso pronunciado por Karl Marx el 14 de abril de 1856 y publicado en el People's Paper del 19 de abril de 1856.

Doane, Mary Anne. Femme Fatales: Feminism, Film Theory, Psychoanalisis. Ed. Routledge. Londres, 1991.

Dollimore, Jonathan. Death, Desire, and Loss in Western Culture. The Penguin Press, Londres, 1998.

Dryden, Linda. The Modern Gothic and Literary Doubles. MacMillan. Basington, 2003.

Dunnat, Sarah, Porter, Roy. The Age of Anxiety. Ed. Virago. Londres, 1996.

El Diccionario de la lengua española (DRAE) es la obra de referencia de la Academia. La edición actual —la 22..$^{\text {, }}$, publicada en 2001. 
Elias, Norbert. The Court Society. Ed. Blackwell, Oxford, 1983.

Elison, David. Ethics and Aesthetics in European Modernist Literature. From the Sublime to the Uncanny. Cambridge University Press, 2001.

Emily P. Tan, Jean. Sarah Kofman as philosopher of the uncanny double: Sarah Kofman's appropriation of Nietzsche and Freud. ProQuest, UMI Dissertation Publishing, 2011.

Entwistle, Joanne. The Fashiones Body. Ed. Sage. London, 2000.

Estrada Mora, C. Olga. La estética y lo siniestro. Rev. Filosófica Univ. Costa Rica, XXIX (70). Pp. 189-196, 1991.

Evans, Caroline. Fashion at the Edge. New Haven, CT. Yale University Press, 2003.

Ferriar, John. MD. An Essay Towards A Theory of Apparition. J. And J. Haddock. London, 1813.

Fielding, Henry. "An Essay on the Knowledge of the Characters of Men". Miscellanies. Oxford Clarendon Press, 1972. Vol. I.

Fielding, Henry. The female husband or, The surprising history of Mrs. Mary, alias Mr. George Hamilton. Online. OTA website.

Fielding, Henry. The Masquerade. Londres, 1728. Reimpreso en Liverpool: Liverpool University Press, 1960.

Finkelstein, Joanne. After Fashion. Melbourne University Press, 1996.

Flügel, J.C. The Psychology of Clothes. Hogarth Press and The Institute of Psychoanalysis. Londres, 1950.

Foster, Hal. Compulsive Beauty. MIT Press, 1993.

Foster, Hal. El retorno de lo real. La vanguardia a finales de siglo. Ediciones Akal. Madrid, 2001.

Foster, Hal. The Return of the Real: The Avant-Garde at the End of the Century. MIT Press, Cambridge,1996.

Foucault, Michel. Herculine Barbin. Introducción. Nueva York. Ed. Pantheon, 1980.

Foucault, Michel. La arqueología del saber. Siglo Veintiuno Editores. México, 1970.

Foucault, Michel. Nietzsche, la genealogía, la historia. Pre-textos. Valencia, 1997.

Foucault, Michel. The History of Sexuality. Volume Two: The Uses of Pleasure. Trad. Robert Hurley. Ed. Pantheon, New York, 1985.

Foucault, Michel. The Order of Things. An Archeology of the Human Sciences. Ed. Vintage, Nueva York, 1973.

Foucault, Michel. Vigilar y castigar. Siglo XXI Editores. México, 2002.

Fraiberg, Selma. Kafka and the Dream. Partisan Review 23. 1956. Pp. 47-69. 
Freud, Sigmund. Consideraciones sobre la guerra y la muerte. Obras completas. Amorrortu Editores. Buenos Aires, 1991.

Freud, Sigmund. Dinámica de la transferencia. Obras completas. Amorrortu Editores. Buenos Aires, 1991.

Freud, Sigmund. El escritor creativo y la ensoñación. Obras completas. Amorrortu Editores. Buenos Aires, 1991.

Freud, Sigmund. El tabú de la virginidad. Obras completas. Amorrortu Editores. Buenos Aires, 1991.

Freud, Sigmund. El tema de la elección de un cofrecillo. Obras completas. Amorrortu Editores. Buenos Aires, 1991.

Freud, Sigmund. La cabeza de la Medusa. Obras completas. Amorrortu Editores. Buenos Aires, 1991.

Freud, Sigmund. La cabeza de Medusa. Obras completas. Amorrortu Editores. Buenos Aires, 1991.

Freud, Sigmund. La interpretación de los sueños. Madrid, Biblioteca Nueva, 1972.

Freud, Sigmund. La interpretación de los sueños. Obras completas. Amorrortu Editores. Buenos Aires, 1991.

Freud, Sigmund. La transitoriedad. Obras completas. Amorrortu Editores. Buenos Aires, 1991.

Freud, Sigmund. Lo siniestro (1919). Obras completas. Amorrortu Editores. Buenos Aires, 1991.

Freud, Sigmund. Lo siniestro. Obras completas. Amorrortu Editores. Buenos Aires, 1991.

Freud, Sigmund. Los instintos y sus vicisitudes. Obras completas. Amorrortu Editores. Buenos Aires, 1991.

Freud, Sigmund. Más allá del principio del placer. Obras completas. Amorrortu Editores. Buenos Aires, 1991.

Freud, Sigmund. Psicopatología de la vida cotidiana. Alianza Editorial. Madrid, 1999.

Freud, Sigmund. Recordar, repetir y reelaborar. Obras completas. Amorrortu Editores. Buenos Aires, 1991.

Freud, Sigmund. The Uncanny (1919). The Standard Edition of the Complete Psychological Works of Sigmund Freud. Hogarth Press, Londres, 1955.

Freud, Sigmund. Tótem y tabú. Obras completas. Amorrortu Editores. Buenos Aires, 1991.

Freud, Sigmund. Un trastorno de la memoria en la Acrópolis. Obras completas. Amorrortu Editores. Buenos Aires, 1991. 
Furedi, Frank. Culture of Fear: Risk-Taking and the Morality of Low Expectations. Ed. Cassell. Londres, 1997.

Fuss, Diana. "Fashion and the Homospectatorial Look". Critical Inquiry. Vol. 18., No. 4. Verano, 1992. pp. 713-737 http://www.jstor.org/stable/1343827

Garber, Marjorie. Skakespeare's Ghost Writers: Literature as Uncanny Causality. Ed. Methuen. Londres, 1987.

García García, Luis Ignacio. Alegoría y montaje. El trabajo del fragmento en Walter Benjamin. 2010.

Geczy, Adam. Karaminas, Vicki. Fashion and Art. Berg. London, 2012.

Giddens, Anthony. Modernity and Self-Identity: Self and Society in the Late Modern Age. Polity Press. Cambridge, 1991.

Graham, Gordon. Philosophy of the Arts: An Introduction to Aesthetics. Routledge. London, 2005.

Greenberg, Clement, O'Brian, John. The Collected Essays and Criticism. University of Chicago Press. Chicago, 1986.

Hanson, Karen. Dressing down Dressing up: The Philosophic Fear of Fashion. Hypatia Vol. 5, No. 2, Feminism and Aesthetics (Summer, 1990), pp. 107-121.

Hecht, Bernard M. Uncanniness, Yearning and Franz Kafka's Works. American Imago 9. 1952. Pp. 45-55.

Heidegger, Martin. Hölderlin's Hymn "The Ister". Indiana University Press. Bloomington, 1996.

Heidegger, Martin. Introducción a la metafísica. Editorial Gedisa. Barcelona, 2001.

Heidegger, Martin. Ser $y$ tiempo.Traducción, prólogo y notas de Jorge Eduardo Rivera .Edición electrónica de www.philosophia.cl / Escuela de Filosofía Universidad ARCIS.

Hepburn, James G. Disarming and Uncanny Visions; Freud's The Uncanny with Regard to Form and Content in Stories by Sherwood Anderson and D.H. Lawrence. Literatures and Psychology 7. 1959. Pp. 9-12.

Hibbert, Samuel. Sketches on Philosophiy of Apparitions, or, An Attempt to Trace Such Illusions to their Physical Causes. London, 1825.

Hobbes, Thomas. Leviathan. Ed. C.B. Macpherson. Harmondsworth, 1968.

Hollander, Anne. Seeing Through Clothes. University of California Press. Berkeley, 1993.

Hollander, Anne. Sex and Suites: The Evolution of Modern Dress. Alfred \& Knopf. New York, 1994.

Horkheimer, Max, Adorno, W. Theodor. Dialéctica de la llustración. Fragmentos Filosóficos. Editorial Trotta. Madrid, 1998.

Hume, D. La norma del gusto. Teorema, Valencia, 1980. 
Hume, D. Tratado de la naturaleza humana. Vol. II, 1, Sección VIII, Ed. Nacional, Madrid, 1981.

Irving, Washingtong. The Complete Works of Washingtong Irivng. Ed. Dahlia Kirby Terrel. Boston, 1979.

Jackson, Rosemary. Fantasy: the Literature of the Subversion. Methuen. London, 1981.

Jameson, Frederic. El Posmodernismo o la lógica cultural del capitalismo avanzado. Ed. Paidós. Buenos Aires, 1991.

Jay, Martin. Downcast Eyes: The Denigration of Vision in Twentieth-Century French Thought. University of California Press. Los Ángeles, 1993.

Jay, Martin. Forced Field. The Uncanny Niineties. Salgamundo, 1995. Reimpreso en Jay, 1998. Pp. 157-164.

Joly, Martine. Introducción al análisis de la imagen. La Marca Editora. Argentina, 2012. Kant, Immanuel. Critica del juicio. Librerías de Francisco Iravedra. Madrid. 1957.

Kawamura, Yuniya. Fashion-ology: An Intoduction to Fashion Studies. Berg. Oxford, 2005.

Kawamura, Yuniya. The Japanese Revolution in Paris Fashion. Berg. Oxford, 2004.

Kayser, Wolfgang. The Grotesque in Art and Literature. New York, Columbia, UP. 1957.

Kelley, Mike, The Uncanny by Mike Kelley, Artist. Exh cat. Liverpool, England: Tate Liverpool; Vienna, Austria: Museum Moderner Kunst Stiftung Ludwig Wien, 2004. English and German-English editions. Essays by Mike Kelley, John Welchman and Christoph Grunenberg.

Kierkegaard, Soren. Tratado de la desesperación. Ediciones Altaya, Barcelona, 1997.

Kofman, Sarah. Freud and Fiction. Northeastern. 1991.

Kofman, Sarah. L'Enfance de l'art. Payot, Paris. 1970.

Kofman, Sarah. Le Double e(s)t le diable. L'inquiétante étrangeté de L'homme au sable (Der Sandmann. 1974.

Kofman, Sarah. Quatre romans analytiques. Galillée. Paris. 1973.

Kondo, Dorine. About Face, Performing Race in Fashion and Theater. Routledge, New York, 1997.

Krauss, Rosalind. The Originality of the Avant-Garde and Other Modernist Myths. MIT Press. Cambridge, 1985.

Kristeva, Julia. Black Sun. Depression and Melancholia. Comlumbia University Press. Nueva York, 1992.

Kristeva, Julia. El sentido y la moda. Ed. Fundamentos, Madrid, 1978. 
Kristeva, Julia. Powers of Horror. An Essay on Abjection. Columbia University Press. Nueva York, 1982.

Lacan, J. Función y Campo de la Palabra y del Lenguaje en Psicoanálisis, Escritos 1, Buenos Aires, Siglo XXI editores, 1988.

Lecky, W.E.H. History of the Rise and Influence of the Spirit of Rationalism in Europe. Appleton, New York. 1919.

Leopardi, Giacomo. Dialogue between Fashion and Death. Repr. Ed. Penguin. London, 1982.

Lipovestky, Gilles. El imperio de lo efímero: La moda y su destino en las sociedades modernas. Ed. Anagrama, Barcelona, 2009.

Lipovetsky, Gilles. The Empire of Fashion: Dressing Modern Democracy. Trad. Catherine Porter. Princeton University Press, 1994.

Locke, John. Ensayo sobre el entendimiento humano. Ed. Alianza, 1990.

Lyotard, Jean-François. Discours, figure. Klincksiek. París, 1971.

Mackrell, Judith. The name's d'Eon. Chevalier d'Edon. The Guardian. 19 de febrero de 2009. Sección Artes.

Madsen, Axel. Living for Design: The Yves Saint Laurent Story. Delacorte Press. New York. 1979.

Marks, W.S. The Psychology of the Uncanny in Lawrence's 'The Rocking.horse Winner'. Modern Fiction Studies 11. 1966. Pp. 381-392.

Martin, Richard. Fashion and Surrealism. Rizzoli. New York, 1987.

Masschelein, Annelen. The unconcept. The Freudian Uncanny in Late TwentiethCentury Theory. Suny Press. United States, 2011.

Mehlman, Jeffrey. Revolution and Repetition. Marx, Hugo, Balzac. University of California Press, Berkeley, 1977.

Miller, J. Hillis. The Critic as Host. Critical Inquiry No. 3. Reprinted in Deconstruction and Criticism. Nueva York, 1985.

Moreno Villagrán, J.M. El pensamiento estético en la obra de Freud. Rev. Asoc. Esp. Neuropsiq. Vol. XII No. 41, 1992. Pg. 55-60.

Mori, Masahiro. The Uncanny Valley. Energy no. 7. 1970. Pp. 33-35.

Müller, Florence. Art and Fashion. Ed. Thames and Hudson. London, 2000. Pp. 12.

Nead, Lynda. Victorian Babylon: People, Streets and Images in Nineteenth-Century London. Yale Universoty Press. New Haven y Londres, 2000.

Newnham, William. Essays in Superstition: Being an Inquiry into de effects of Physical Influence on the Mind, in the Production of Dreams, Vision, Ghosts, and other supernatural Appearances. London, 1830. 
Nowak, Magdalena. "The Complicated History of Einfühlung”. Argument. Vol.1, 2011. Pp. 301-326.

Olga C. Estrada Mora, "La estética y lo siniestro (I)," Revista filosófica (Costa Rica) 29 (1991): 189-196.

Olga C. Estrada Mora, "La estética y lo siniestro (II)," Revista filosófica (Costa Rica) 30 (1992): 63-72.

Owens, Craig. El impulso alegórico. Hacia una teoría del postmodernismo. Trad. Fernando Galván. Revista Atlántica, no 1, 1991 Islas Canarias, http://biblioteca.ulpgc.es/avisomdc

Pacteau, Francette. The Symptom of Beauty. Reaktion Books. London, 1994.

Park, Julie. Unheimlich Maneuvers: Enlightenment Dolls and Repetitions in Freud. The Eighteenth Century. Palgrave, 2001.

Parker, Gustavus. An account of a Portable Barometer. Michigan: University of Michigan, Digital Library Production Service. Diciembre, 2011.

Penzoldt, Peter. Introduction to The Supernatural in Fiction, Peter Nevill. London, 1952.

Prawer, Siegbert S. Hoffmann's Uncanny Guest: A Reading of Der Sandmann. Duckworth, London. 1973.

Prawer, Siegbert S. Reflections on the Numinous and the Uncanny in German Poetry. Butterworths, London. 1963.

Prawer, Siegbert S. The Uncanny in Literature. An Apology for its Investigation. Westfield Collefe, London. 1965.

Prawer, Siegbert. The Uncanny in Literature. An Apology for its Investigation. Westfield College, London. 1965.

Proust, Marcel. En busca del tiempo perdido I. Por el camino de Swann. Spanish eletronic edition.

Quigley, Martin Jr. Magic Shadows: The Story of the Origin of Motion Pictures. New York, 1960.

Rabaté, Jean-Michel. The Ghosts of Modernity. University Press of Florida. Gainsville, 1996.

Radcliffe, Anne. Los misterios de Udolfo. Ed. Valdemar. Madrid, 1992.

Rank, Otto. El doble. Ediciones Orión. Buenos Aires. 1980.

Reik, Theodor. The Strange God and One's Own God. Trans. Douglas Bryan. Grove Press, Inc. New York, 1962.

Rothenberg, Molly Anne, Valente, Joseph. "Fashionable Theory and Fashion-Able Women: Returning Fuss's Homospectatorial Look". Critical Inquiry. Vol. 22, No. 22. Invierno, 1996. pp. 372-382. http://www.jstor.org/stable/1343976 
Rousseau, Jacques-Jean. Las ensoñaciones del paseante solitario. Alianza Editorial. España, 2008.

Royle, Nicholas. The Uncanny. Manchester University Press / Routledge. 2013.

Sadler, Ted. Heidegger and Aristotle. The Question of Being,. The Athlone Press, London. 1996.

Samuel, Raphael. Theatres of Memory. Past and Present in Contemporary Culture. Ed. Verso, Londres, 1994.

Santaliera Oliván, Lucía. La Alegoría en El origen del Drama Barroco Alemán de Walter Benjamin y en Las Flores del Mal de Baudelaire.

Sartre, Jean Paul. El ser y la nada. Ediciones Calden. Buenos Aires, 1968.

Sawday, Jonathan. The Body Emblazoned: Dissection and the Human Body in Renaissance Culture. Ed. Routledge. London, 1995.

Sayings of the Week, Observer. Noviembre 1, 1992.

Schulz, Bruno. La calle de los cocodrilos. Centro Editor de América Latina, S. A., Buenos Aires, 1982.

Scott, Walter. Letters on Demonology and Witchcraft. Routledge and Sons. Lafayette. 1885.

Sedgewick, Owen. "The Universal Masquerade."Londres, 1872 en British Enssayists. Ed. Alexander Chalmers. Boston 1908.

Sellers, Susan. The Hélène Cixous Reader. Routledge. London, 1994.

Seltzer, Mark. Serial Killer. Death and Life in America's Wound Culture. Routledge. Nueva York, 1998.

Shorthouse, Joseph Henry. John Inglesant: A Romance. New York, 1897.

Shwartz, Hillel. La cultura de la copia: parecidos sorprendentes, facsímiles insólitos. Cátedra. Madrid, 1998.

Siegel, James. Naming the Witch. Stanford University Press, Stanford, 2006.

Squicciarino, N. El vestido habla. Ed. Cátedra. Madrid, 1986.

Stanford Friedman, Susan. Joyce. The Return of the Repressed. Cornell University Pres, Ithaca, 1993.

Steele, Valerie. Woman of Fashion. Twentieth Century Designers. Rizzoli International. New York, 1991.

Stewart, Susan. On Longing. Narratives of Miniature, the Giagantic, the Souvenir, the Collection. Duke University Press. London, 1993.

Tatarkiewicz, W. Historia de seis ideas. Arte, belleza, forma, creatividad, mímesis. Ed. Tecnos, Madrid. 1990.

The Centenary Edition of the Works of Nathaniel Hawthorne. Colombus, Ohio, 1964. 
Thomas, Keith. Religion and the Decline of Magic. Penguin Books. London. 1978.

Tickner, Lisa. Modern Lives and Modern Subjects. Paul Mellon Centre for Studies in British Art. London, 2000.

Tickner, Lisa. Modern Lives and Moderns Subjects. Yale University Press. New Haven, 2000.

Todorov, Tzvetan. Introducción a la literatura fantástica. Premia Editora. México, 1981.

Tría, Eugenio. Lo bello y lo siniestro. Ed. Ariel. Barcelona, 2001.

Troy, Nancy. Couture Culture: A Study in Modern Art and Fashion. MIT Press. Cambridge, 2004.

Turner, Bryan. Theories of Modernity and Postmodernity. Ed. Sage, Londres, 1990.

Urdanoz, T. Nuevas formas del Idealismo moderno. Historia de la filosofía. Vol. VI. BAC. Madrid, 1978.

Vax, Louis, L'Art et la littérature fantastique. Presses Universitaires de France. Paris, 1970.

Vax, Louis. La Séduction de l'etrange. Presses Universitaires de France. Paris, 1965.

Vax, Louis. Les chefs-d'oeuvres de littérature fantastique. Paris Presses Universitaires de France, 1979.

Vidler, Anthony. The Architectural Uncanny. Essays in the Modern Unhomely. MIT Press, Cambridge, 1996.

Villagrán Moreno, J.M. El pensamiento estético en la obra de Freud. Rev. Asoc. Esp. Neruopsiq. Vol. XII No. 41, 1992.

Wallerstein, Katherine. Thinnes and Other Refusals in Contemporary Fashion Advertisements. Fashion Theory, Vol. 2. Junio, 1998. Pp. 129-150.

Weber, Andrew. Otto Rank and the Doppelgänger. Edinburgh University Press, Edinburgh 1992.

Weber, Samuel. The Legend of Freud. Stanford University Press, Stanford, 1996.

Weber, Samuel. The Slideshow, or: Remarks on a Canny Moment. Stanford University Press, Stanford, 1973.

Weeks, Jeffrey. Invented Moralities: Sexual Values in an Age of Uncertainty. Columbia University Press. Nueva York, 1995.

Wigley, Mark. The Architecture of Deconstruction. Derrida'as Hunt. MIT Press, Cambridge, 1996.

Williams H.,Rosalind. Dream Worlds: Mass Consumption in Late Nineteenth Century France. University of California Press. Los Ángeles, 1982.

Wilson, Elizabeth. Adorned in Dreams: Fashion and Modernity. Ed. Virago, Londres, 1985. 
Wolff, Janet. The Invisible Flâneuse: Women and the Literature of Modernity, incluido en el compendio Femenine Sentences: Essays on Women and Culture. Polity Press. Cambridge, 1990. Pp.34-50.

Wolfreys, Julian. Victorian Hauntings: Spectrality, Gothic, the Uncanny and Literature. Palgrave, 2001.

Wollen, Peter. Addressing the Century: 100 Yearsof Art and Fashion. Hayward Gallery Publishing. London, 1998.

Wosk, Julie. Breaking Frame: Technology and the Visual Arts in the Nineteenth Century. Rutgers University Press. New Brunswick, 1992.

Wright, Elizabeth. Speaking Desires can be Dangerous. The Poetics of the Unconsciousness. Polity, Cambridge, 1999.

Wright, Elizabeth. The Uncanny and Surrealism. Polity, Cambridge, 1998.

Zavitzianos, George. Homeovestism: Perverse Form of Behaviour Involving the Wearing of Clothes of the Same Sex. International Journal of Psychoanalysis, 1972. Pp. 471-477.

Zavitzianos, George. The Object in Fetishism, Homeovestism, and Transvestism. International Journal of Psychoanalysis, 1977. Pp. 487-495.

Ziarek, Ewa. The Uncanny Style of Kristeva's Critique of Nationalism Postmodern Culture 5. http:// jefferson.village.virginia.edu>

Zizek. Slavoj. Looking Awry An Introduction to Jacques Lacan through Popular Culture. University of Indiana Press, 1990.

Zola, Émile. El paraíso de las damas. Alba Editorial. Barcelona, 1999. 
